\title{
Heat stress pretreatment in cardiac ischemia : protection of the adult and aged hypertrophied heart
}

Citation for published version (APA):

Cornelussen, R. N. M. (1996). Heat stress pretreatment in cardiac ischemia : protection of the adult and aged hypertrophied heart. [Doctoral Thesis, Maastricht University]. Rijksuniversiteit Limburg. https://doi.org/10.26481/dis.19961017rc

Document status and date:

Published: 01/01/1996

DOI:

10.26481/dis.19961017rc

Document Version:

Publisher's PDF, also known as Version of record

\section{Please check the document version of this publication:}

- A submitted manuscript is the version of the article upon submission and before peer-review. There can be important differences between the submitted version and the official published version of record.

People interested in the research are advised to contact the author for the final version of the publication, or visit the DOI to the publisher's website.

- The final author version and the galley proof are versions of the publication after peer review.

- The final published version features the final layout of the paper including the volume, issue and page numbers.

Link to publication

\footnotetext{
General rights rights.

- You may freely distribute the URL identifying the publication in the public portal. please follow below link for the End User Agreement:

www.umlib.nl/taverne-license

Take down policy

If you believe that this document breaches copyright please contact us at:

repository@maastrichtuniversity.nl

providing details and we will investigate your claim.
}

Copyright and moral rights for the publications made accessible in the public portal are retained by the authors and/or other copyright owners and it is a condition of accessing publications that users recognise and abide by the legal requirements associated with these

- Users may download and print one copy of any publication from the public portal for the purpose of private study or research.

- You may not further distribute the material or use it for any profit-making activity or commercial gain

If the publication is distributed under the terms of Article $25 \mathrm{fa}$ of the Dutch Copyright Act, indicated by the "Taverne" license above, 


\section{HEAT STRESS PRETREATMENT IN CARDIAC ISCHEMIA}

PROTECTION OF THE ADULT AND AGED HYPERTROPHIED HEART 
(C) Richard Cornelussen, Maastricht 1996

ISBN 90-900982-6

Vormgeving en druk: Datawyse I Universitaire Pers Maastricht

Het verschijnen van dit proefschrift werd mede mogelijk gemaakt door de steun van de Nederlandse Hartstichting 


\title{
HEAT STRESS PRETREATMENT IN CARDIAC ISCHEMIA
}

PROTECTION OF THE ADULT AND AGED HYPERTROPHIED HEART

\section{PROEFSCHRIFT}

\author{
ter verkrijging van de graad van doctor \\ aan de Rijksuniversiteit Limburg te Maastricht, \\ op gezag van de Rector Magnificus, Prof. mr. M.J. Cohen, \\ ingevolge het besluit van het College van Dekanen \\ in het openbaar te verdedigen op \\ donderdag 17 oktober 1996 om 14.00 uur
}

door

Richard Nicolaas Marie Cornelussen

geboren te Maastricht op 4 december 1967 


\section{Promotores:}

Prof. dr. R.S. Reneman

Prof. dr. G.J. van der Vusse

\section{Co-promotor:}

Dr. L.H.E.H. Snoeckx

\section{Beoordelingscommissie:}

Prof. dr. J.W. Arends (voorzitter)

Prof. dr. M. Borgers

Dr. L. Rappaport (INSERM U-127, Parijs, Frankrijk)

Prof. dr. J.F.M. Smits

Prof. dr. A. van der Laarse (Rijksuniversiteit Leiden) 
Voor Aggie en Kathy 


\section{Contents}

Chapter 1

General introduction 9

Chapter 2

Heat shock improves the ischemia tolerance of the hypertrophied rat heart 27

Chapter 3

Improvement of postischemic cardiac function in the heat-shocked hypertrophied and non-hypertrophied heart is perfusion pressure dependent 41

Chapter 4

Heat shock protects the aged hypertrophied and non-hypertrophied rat heart against ischemia and reperfusion damage 51

Chapter 5

Biphasic effect of heat stress pretreatment on the ischemic tolerance of isolated rat hearts $\quad 65$

Chapter 6

Inability of the heat-shocked heart to adjust its preischemic and postischemic performance to variable loading conditions 79

Chapter 7

Calcium homeostasis in cardiomyocytes isolated from heat-shocked hearts 91

Chapter 8

General discussion $\quad 109$

Summary 119

Samenvatting 123

Publications and Abstracts 129

Curriculum Vitae $\quad 131$

Dankwoord 132 
Chapter 1

GENERAL INTRODUCTION 


\section{Introduction}

Proper cardiac functioning depends on a continuous supply of substrates and oxygen as the heart is obligatorily dependent on oxidative processes for energy conversion. Impaired flow in the coronary arteries (ischemia) rapidly leads to disturbed mechanical function and metabolism. Prolonged ischemia is known to result in irreversible damage of cardiac structures. Unlike in other organs, increased oxygen supply to the myocardium can be achieved only by increasing coronary flow because the extraction of oxygen from the blood is almost maximal in the resting normoxic situation. In the human heart myocardial ischemia may occur as a consequence of coronary artery disease, which may ultimately result in myocardial infarction when the coronary arteries become severely occluded. The severity of myocardial ischemia will also be determined by the degree of collateral circulation from the non-ischemic zone. Another form of ischemia, global ischemia, occurs when the whole heart is deprived of its coronary flow and, hence, of oxygen supply, as for example during cardiopulmonary bypass surgery.

To minimize the extent of damage induced by ischemia it is crucial to adequately restore coronary flow as soon as possible. Restoration of flow after an ischemic episode, however, is not without risk and may result in reperfusioninduced injury [38; 82]. Factors responsible for cardiac reperfusion injury include the generation of oxygen free radicals promoting cellular membrane damage $[28 ; 63$ ] and the excessive accumulation of calcium ions in the cytoplasm of cardiomyocytes leading to contracture [8; 32]. Reperfusion has also been associated with massive cellular edema and cell swelling [46].

Some types of hearts tolerate ischemia less well than others. For instance, the pathologically hypertrophied heart is more vulnerable to ischemia than the nonhypertrophied heart $[12 ; 100]$. Factors possibly responsible for this increased sensitivity towards ischemia and/or reperfusion damage are reduced coronary vasodilatory reserve, increased incidence of ventricular arrhythmias, reduced anaerobic glycolytic capacity, and/or increased cytoplasmic calcium concentration [4]. Pressure overloaded hypertrophied hearts have also been reported to have lower ATP levels than non-hypertrophied control hearts, both under normoxic and ischemic conditions [2; 103]. During reperfusion in the hypertrophied heart, a further decrease of ATP accelerates calcium overload due to depressed activity of the ATP-dependent sarcoplasmic reticulum and sarcolemmal calcium pumps [45].

Also the aged heart has been shown to be more vulnerable to ischemia than the heart at younger age [101]. The impaired postischemic recovery of the aged heart might result from cardiomyocyte loss [3], increased connective tissue content and/or excessive myocyte hypertrophy in combination with inadequate capillary growth [3; 27; 52]. This may lead to increased diffusion distances and, hence, diminished oxygen exchange resulting in compromised function. The aged hypertrophied heart is even more susceptible to ischemic and reperfusion damage than age-matched controls [101].

The heart can be protected against ischemia/reperfusion damage, either extrinsically by application of protective measures or intrinsically by the activation of endogenous protective mechanisms. Extrinsic cardiac protection against ischemia/reperfusion damage can be achieved by various interventions. For example, during cardiac surgery the use of cardioplegic solutions, thereby arresting the entire heart in a relaxed condition improves cardiac recovery upon reperfusion (reviewed in [39]). Furthermore, calcium channel blocking drugs which reduce the 
amounts of calcium entry into cardiac cells, have been proven effective in reducing injury induced by ischemia and reperfusion $[26 ; 50 ; 115]$. Also reperfusion with blood containing low extracellular calcium concentrations or free radical scavengers such as superoxide dismutase and catalase improves postischemic hemodynamic functional performance $[24 ; 47 ; 96 ; 115]$. Free radical mediated injury to cardiac cells can also be decreased by initial reperfusion with buffer lacking oxygen [40].

During the last decade two new experimental methods based on intrinsic myocardial protection against ischemia/reperfusion damage have drawn attention [121]. Although at present these techniques are not clinically operational, they allow dissection of the mechanisms involved in ischemia and reperfusion damage and to define new approaches to the improvement of postischemic functional recovery. Both methods activate endogenous protective mechanisms in the heart. In the first, called ischemic preconditioning, short episodes of coronary occlusion and reperfusion are applied before a subsequent longer period of ischemia [23]. After preconditioning the functional recovery following an ischemic period was found to be significantly better than in control hearts. In the second approach, named stresspreconditioning, a special set of proteins is expressed before the onset of ischemia. Increased myocardial concentrations of these so-called heat shock proteins (HSPs) transiently protect the heart against a subsequent ischemic insult $[17 ; 73 ; 109 ; 120]$. Interestingly, the protective effects of heat pretreatment were originally described in 1975 in another context, i.e. in the protection of cells against a second, normally lethal heat stress [29]. Its role in protection of the heart against ischemia and reperfusion was discovered in 1988 by Currie and colleagues [17]. These investigators described a significant improvement of postischemic functional recovery of isolated rat hearts, when the animals were exposed to a short period of elevated body temperature 24 hours before the ischemic insult.

\section{Induction of heat shock proteins}

In 1962 Ritossa observed for the first time the development of chromosomal puffs in the salivary gland tissue of Drosophila busckii upon exposure of the larvae to elevated environmental temperatures [91]. Later, Tissières discovered that these altered chromosomal structures were associated with the synthesis of a small set of proteins, which were called "heat shock proteins" (HSPs) [112]. Later it was found that isolated cells or intact animals subjected to an elevated temperature became transiently thermotolerant (reviewed in [58]). Thermotolerance refers to the ability of organisms to withstand normally lethal temperatures after pre-exposure to an elevated sublethal temperature for a relatively short period of time [57]. It became rapidly obvious that this 'heat-shock' response was universal and could be observed from bacteria to man (reviewed in [58; 98]). Furthermore HSPs seemed to be highly conserved during evolution [58] and to have a special role in protecting living organisms during subsequent physiologically stressful events [116]. In addition to heat shock the expression of most of the HSPs could also be induced by such stresses as exposure to heavy metals, alcohol and metabolic poisons (for reviews see [30; 59]). Since the response could be elicited by other types of stress than heat, the alternative terms "stress response" and "stress proteins" have been proposed. Although a number of HSPs can be induced upon enhanced cellular stress, other members of the HSP families are expressed constitutively and are thus permanently present intracellularly [58].

The typical cellular response to a non-physiological stress, such as heating to sublethal temperatures, has been studied extensively in cultered cells. Immediately 
after exposure to an elevated temperature protein translation is inhibited. During this first phase the morphological features of the affected cell changes and is characterized by damaged cytoskeletal structure and alterations in the nucleus, such as the occurrence of inclusion bodies containing actin filaments [118; 119]. As a consequence of heat-induced protein denaturation the activity of most enzymes decreases. After the stress period but before normal protein synthesis is resumed, transcription of heat shock genes coding for both the inducible and, to a minor extent, the constitutive HSPs is activated [86; 97]. This transcriptional activation of heat shock genes is mediated by transcription factors, called heat shock factors (HSFs), which bind to heat shock response elements (HSEs) in the upstream promoter region of most of the genes coding for heat shock proteins. Under normal circumstances, the HSFs are bound in the cytoplasm to proteins belonging to the HSP $70 \mathrm{kDa}$ family [60]. As such, the latter proteins regulate their own expression level through their binding to HSFs.

The structure of the mRNAs coding for HSPs of the HSP70 family promotes their selective translation in a stressed cell, because they contain regions in the 5'untranslated region which enhance translational efficiency [97; 111]. After cessation of the stress the time needed to recover normal overall protein synthesis depends upon the severity of the stress period [76]. In isolated cells normal protein synthesis resumes on the average 9 hours after initiation of HSP synthesis [76].

\section{The heat shock protein families}

In eukaryotic and prokaryotic organisms heat shock proteins (HSPs) are usually divided into 5 major families based upon their molecular mass, i.e. the small HSP family and the $60 \mathrm{kDa}, 70 \mathrm{kDa}, 90 \mathrm{kDa}$, and $100 \mathrm{kDa}$ families (Tables 1 and 2). Except for the members of the small HSP family, all other HSPs are well conserved during evolution. For instance, both HSP72 and HSP73 in eukaryotes share approximately $50 \%$ amino-acid identity with the prokaryote homologue, called DnaK $[34 ; 116]$. Although the molecular mass and structure of various HSPs in eukaryotic and prokaryotic organisms are very similar, the corresponding proteins have different names. Within the families, both inducible and constitutive forms of HSPs can be distinguished [58; 59].

The small HSPs family. This family is the least conserved of all HSP families and varies in molecular mass between 8 and $47 \mathrm{kDa}$. In plants, these proteins are the most prominent HSPs [114]. In mammalian cells, the most common small HSP has a molecular mass of $27 \mathrm{kDa}$. This protein normally resides in the cytoplasm and/or nucleus and forms large aggregates of up to 700-1000 kDa [5; 7]. Upon heat shock phosphorylation and desaggregation occurs before the cytosolic protein migrates into the nucleus [5]. Overexpression of HSP27 in mammalian cells leads to thermotolerance [53]. alpha- $B$ crystallins with a molecular mass of about $20 \mathrm{kDa}$ are structurally related to HSP27 [74]. Alpha-B crystallins are the major vertebrate eye lens proteins and are involved in maintaining lens stability and transparency. A common feature of HSP27 and $\alpha \mathrm{B}$ crystallin is that both proteins are phosphorylated in response to stress $[15 ; 20]$. The precise role of this phosphorylation is as yet unknown.

In response to heat and other stimuli another relatively small protein is expressed. This $8 \mathrm{kDa}$ HSP, ubiquitin, facilitates the degradation of malfolded proteins [9]. Rapid degradation of damaged proteins reduces the possibility of 
deleterious interactions with other functional proteins. Besides, the formation and precipitation of insoluble protein aggregates are prevented and amino acids present in non-functional polypeptides can be recycled for the synthesis of new proteins. In eukaryotes, ubiquitin is the only HSP involved in the degradation of abnormal proteins. In prokaryotes the majority of small HSPs, like all other HSPs, takes part in proteolytic pathways.

Table 1: Stress proteins in eukaryotes with their subcellular location and pattern of expression.

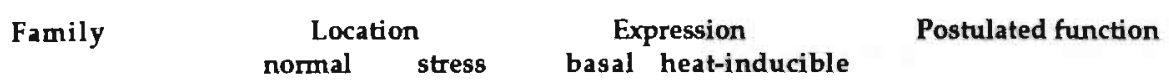

Small HSPs-family

\begin{tabular}{|c|c|c|c|c|c|}
\hline $\begin{array}{l}\text { Ubiquitin } \\
\text { HSP10 }\end{array}$ & $\begin{array}{l}\text { Cytosol } \\
\text { Cytosol }\end{array}$ & Cytosol & $\begin{array}{l}\text { yes } \\
\text { yes }\end{array}$ & $\begin{array}{l}\text { yes } \\
\text { little }\end{array}$ & $\begin{array}{l}\text { Proteolysis } \\
\text { Proteolysis/Stimulates HSP60 }\end{array}$ \\
\hline$\alpha \mathrm{B}-$ Crystallin & Cytosol & Nucleus & yes & yes & Thermotolerance \\
\hline HSP27 & $\begin{array}{l}\text { Nucleus } \\
\text { Cytosol } \\
\text { Nucleus }\end{array}$ & Nucleus & yes & $\begin{array}{l}\text { phosphoryl. } \\
\text { yes } \\
\text { phosphoryl. }\end{array}$ & Cell growth \\
\hline $\begin{array}{l}\text { Heme-oxygenase } \\
\text { HSP47 }\end{array}$ & $\begin{array}{l}\text { Cytosol } \\
\text { ER }\end{array}$ & $\begin{array}{l}\text { Cytosol } \\
\text { ER }\end{array}$ & $\begin{array}{l}\text { yes } \\
\text { yes }\end{array}$ & $\begin{array}{l}\text { yes } \\
(?)\end{array}$ & $\begin{array}{l}\text { Enzyme in heme catabolism } \\
\text { Collagen translocation } \\
\text { into ER }\end{array}$ \\
\hline
\end{tabular}

HSP60-family

HSP60 Mito Mito (?) yes little Protein oligomerization

HSP70-family

\begin{tabular}{|c|c|c|c|c|c|}
\hline HSP72 & $\begin{array}{l}\text { Cytosol } \\
\text { (Nucleus) }\end{array}$ & Nucleolus & minor & strong & $\begin{array}{l}\text { Protein folding/assembly } \\
\text { / translocation }\end{array}$ \\
\hline HSP73 & $\begin{array}{l}\text { Cytosol } \\
\text { (Nucleus) }\end{array}$ & Nucleolus & yes & little & $\begin{array}{l}\text { Protein folding/assembly } \\
\text { /translocation }\end{array}$ \\
\hline HSP75 & Mito & Mito & yes & little & Protein folding/assembly \\
\hline GRP78 (BiP) & $\mathrm{ER}$ & ER & yes & little & $\begin{array}{l}\text { Protein trafficking } \\
\text { through the ER }\end{array}$ \\
\hline
\end{tabular}

HSP90-family

$\begin{array}{cccccl}\text { HSP90 } & \begin{array}{c}\text { Cytosol } \\ \text { Nucleus }\end{array} & \text { Nucleus } & \text { yes } & \text { yes } & \begin{array}{l}\text { Regulator glucocorticisid } \\ \text { receptor }\end{array} \\ \text { GRP94 } & \text { ER } & \text { ER } & \text { yes } & \text { no } & \text { (?) }\end{array}$

HSP100-family

\begin{tabular}{|c|c|c|c|c|c|}
\hline HSP104 & $\begin{array}{l}\text { Nucleus } \\
\text { Cytosol }\end{array}$ & Nucleus & yes & yes & $\begin{array}{l}\text { Thermotolerance } \\
\text { Associates with chromatin }\end{array}$ \\
\hline HSP110 & $\begin{array}{l}\text { Nucleolus } \\
\text { Cytosol }\end{array}$ & Nucleus & yes & yes & Thermotolexance \\
\hline
\end{tabular}

In general, all members of the different HSP-families are involved in the acquisition of thermotolerance. When thermotolerance is mentioned as postulated function, no other function is known yet. GRP: glucose regulated protein which means that these proteins are primarily induced upon glucose starvation. BiP: binding protein: ER: endoplasmic reticulum; Mito: mitochondrion. 
The HSP60 family. The members of this family, i.e. HSP60 in eukaryotes and GroEL in prokaryotes, mediate the folding of newly synthesized proteins. Since these proteins are so actively involved in the assembly of complex proteins, they are also called chaperonins [25]. By studying GroEL in bacteria it was found that HSPs of different families interact with each other [64]. For instance, in order to bind unfolded proteins GroEL needs to be associated with GroES (HSP10 in eukaryotes), another small prokaryotic HSP [54]. As such GroES is necessary to stimulate the ATPase activity of GroEL [69].

The HSP70 family. In eukaryotic cells the HSP70 family consists of four major proteins as listed in Table 1 [36]. From the four members of this protein family three have a major constitutive expression, which only increases slightly upon heat stress. These members are HSP73, HSP75, and the glucose-regulated protein GRP78. In contrast HSP72 has almost no constitutive expression but is strongly induced upon heat stress (own observations and [72]). Within the family, the GRP78 protein has a special position. Although it is almost not induced by heat stress, expression is strongly enhanced upon glucose starvation, abnormal calcium influx and/or hypoxia [56].

Under non-stressed conditions, distinct members of this protein family are found in the cytoplasm, endoplasmatic reticulum and mitochondria and to a lesser extent in the nucleus. The endoplasmatic reticulum contains GRP78 [35]. Therefore, it is not surprising that this protein is involved in protein trafficking through this organelle [30]. At his carboxy-terminal end the protein carries a retention sequence which prevents the protein to be transported into the Golgi apparatus [78]. HSP75 is constitutively expressed and is targeted to mitochondria, as the protein contains a amino-terminal leader sequence required for mitochondrial translocation [14]. HSP75 is involved in protein folding and transfer of proteins from the cytoplasm into the mitochondria [48]. HSP73 and low amounts of HSP72 reside primarily in the cytoplasm. HSP73 is involved in protein folding and guiding of proteins into the different cellular compartments, and in the assembly of macromolecular protein complexes $[6 ; 93]$. Because all three constitutively expressed members of the HSP70 family are involved in assembling, folding and guiding of other proteins, they are also called 'chaperones'. This chaperone function is illustrated in figure 1.

Upon heat stress, HSP72 is induced and the protein translocates from the cytoplasm to the nucleus where it associates with the nucleolus [117]. Upon heat stress, HSP73 translocates similarly as HSP72. The exact mechanism responsible for this movement is as yet unknown. A more detailed description of the function of HSI72 and HSP73 is given below.

The HSP90 family. Within eukaryotes the HSP90 family consists of two members, i.e. HSP90, which normally resides in the cytosol and nucleus, and GRP94, which normally can be found in the endoplasmic reticulum. A well known function of HSP90 is to facilitate the transport of the glucocorticoid receptor into the nucleus [1]. Upon heat shock the expression of HSP90 but not of GRP94 increases and the cytosolic HSP90 migrates to the nucleus [106]. Proteins of the HSP90 family can bind ATP and display ATPase activity required for the binding and release of other proteins [79]. The precise function of GRP94 however is not yet clear. The homologue of HSP90 in prokaryotes is Lon, a protease [87]. 
Table 2: Most important stress proteins in prokaryotes with their pattern of expression.

Family Eukaryotic homologue $\begin{gathered}\text { Expression } \\ \text { basal heat-inducible }\end{gathered}$

\begin{tabular}{|c|c|c|c|c|}
\hline GroES & HSP10 & yes & little & $\begin{array}{l}\text { Proteolysis } \\
\text { Stimulates GroEL function }\end{array}$ \\
\hline ClpP - & - & yes & yes & Proteolysis \\
\hline DraJ & HSP47 & yes & yes & $\begin{array}{l}\text { Regulator HSP-synthesis } \\
\text { Proteolysis } \\
\text { Stimulates DnaK function }\end{array}$ \\
\hline GroEL & HSP60 & yes & little & $\begin{array}{l}\text { Proteolysis } \\
\text { Required for growth at } \\
\text { high temperatures }\end{array}$ \\
\hline DnaK & HSP72/HSP73 & yes & yes & $\begin{array}{l}\text { Protein stabilization } \\
\text { DNA replication } \\
\text { RNA transcription }\end{array}$ \\
\hline Lon & HSP90 & yes & yes & Proteolysis \\
\hline ClpA & HSP104 & yes & yes & $\begin{array}{l}\text { Thermotolerance } \\
\text { Proteolysis }\end{array}$ \\
\hline
\end{tabular}

Beside the mentioned postulated functions, all members of the different HSP-families in prokaryotes are involved in the acquisition of thermotolerance.

The HSP100 family. This family of proteins has been discovered relatively recently compared to the other HSP families [59]. In eukaryotes, HSP110 and HSP104 are constitutively expressed and localized in both the nucleus and the cytoplasm [110]. Both proteins are involved in thermotolerance at extremely high temperatures i.e. $25^{\circ} \mathrm{C}$ above normal growing temperature [94]. Upon stress, the expression of HSP110 and HSP104 is increased, and the proteins are redistributed to the cell nucleus [88]. In prokaryotes, the ClpA, protein which is homologous to HSP104, is essential in proteolytic pathways, since it has protease activity when it acts in concert with ClpP, another prokaryotic HSP of this family [31].

\section{Function of HSP72 and HSP73}

In mammals, the homology of the HSP72 and HSP73 proteins is very high within the same animal species. For instance, in the rat the degree of identity at the amino acid level of both proteins is higher than $90 \%[61 ; 105]$. The most striking differences are present at the carboxy-terminus. Both proteins contain a highly conserved amino-terminal portion carrying an ATP-binding domain with a weak ATPase activity. This ATPase is required for the release and binding of immature and partially denatured proteins [83]. A calmodulin-binding site is also present at the amino-terminus [108], but the precise function of this binding is still unknown. The carboxy-terminus of the protein contains a nuclear localization domain and a nucleolus-association domain [75] (see figure 2). Long chain fatty acids can bind noncovalently to HSP73 and HSP72, indicating the presence of a hydrophobic pocket on the surface of the protein [33]. This pocket is most likely involved in the binding of 
hydrophobic regions of incompletely folded or denatured polypeptides [84; 85]. Nucleotide binding, substrate binding, and phosphorylation may all alter the conformation and ATPase activity of HSP72 and HSP73 [30; 85].

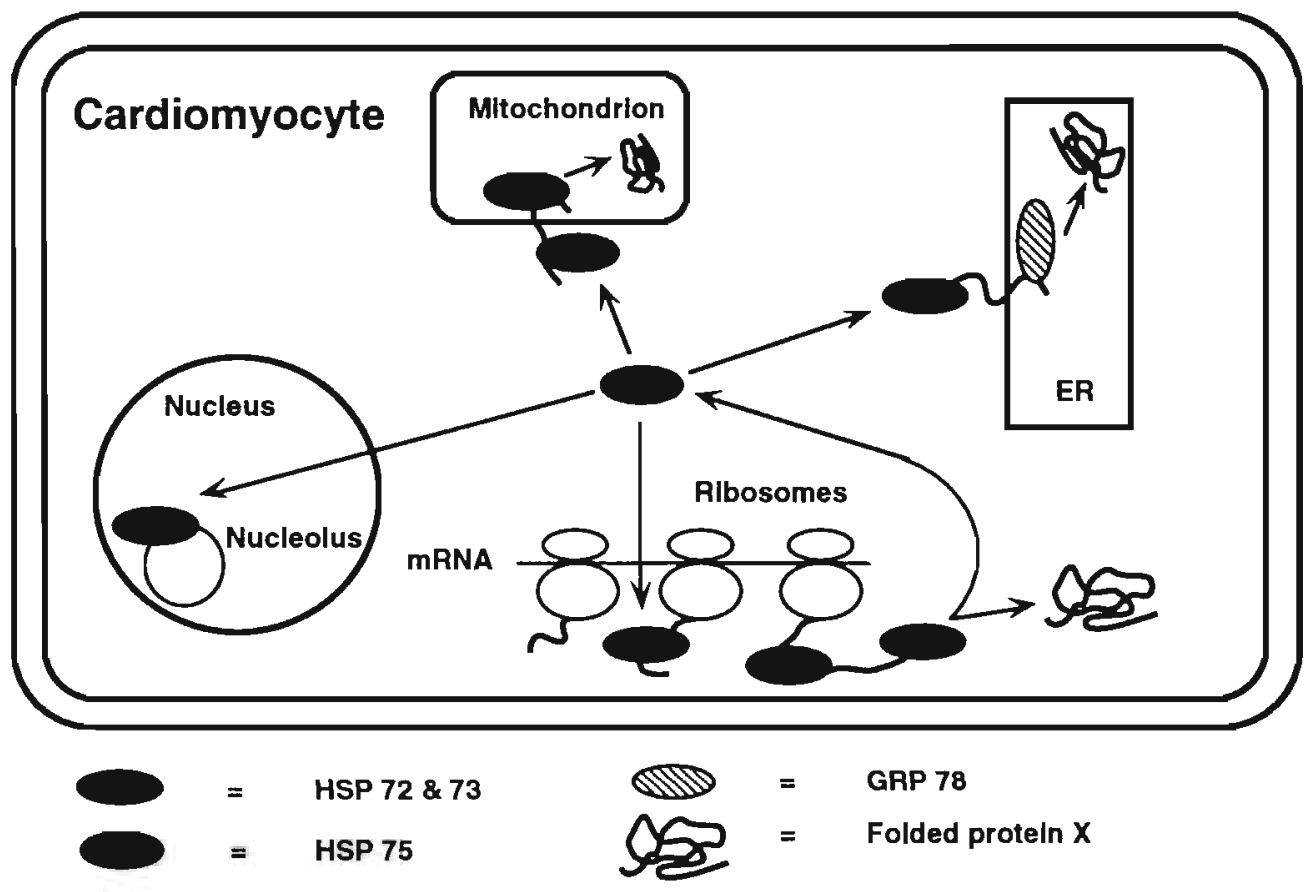

Figure 1: Interaction between the different members of the HSP70-family in the guidance of proteins into the different compartments of the non-stressed cell (with permission from [42]). ER = endoplasmic reticulum.

Under normal conditions, like HSP75 and GRP78 the constitutively expressed protein HSP73 is involved in protein folding and guiding of proteins into the different cellular compartments, and in the assembly of macromolecular protein complexes [6, 93]. The postulated role of the inducible HSP72 is protection of cells against different types of environmental stress [90]. For instance, it has been shown that HSP72, like other HSPs, is associated with thermotolerance and increased resistance against metabolic and ischemic stress [37; 65; 95]. Cellular protection is probably the result of several mutually interacting mechanisms. In the first place, the enhanced quantities of HSP72 in stress situations prevent denatured polypeptides to aggregate and precipitate [85]. Secondly, since HSP72 is translocated into the nucleus and associates with preribosomal complexes in the nucleolus, these structures are likely the first targets for protection, so that normal protein synthesis can proceed after cessation of stress. The concentration of HSPs induced during stress remains elevated for only a relatively short period of time, i.e. 48 hours. After return of HSP72 to control levels, protection against environmental stress is no longer present [49]. 

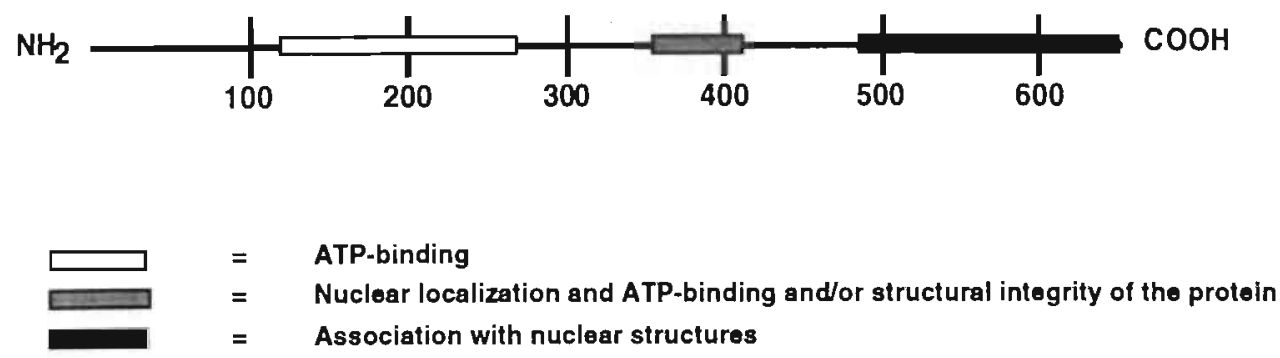

Figure 2: Functional domains of HSP72 and HSP73, identified by analysis of deletion mutants [75].

There are also "normal" cellular conditions during which the expression of HSP72 is increased. Such conditions are cellular growth, development and differentiation, implying that this protein also contributes to physiological processes [77].

In conclusion, in normal non-stressed situations the HSP73 and HSP72 proteins act as chaperons, as they associate with nascent polypeptides either to guide their transport into cellular organelles or to favor adequate folding required for their final physiological function. Upon stress, binding to partially denatured proteins prevents proteolysis and aggregation so that these proteins become available when the stress period is over.

\section{Heat shock proteins and protection against cardiac ischemia}

Although the relationship between thermotolerance and increased cellular levels of HSPs has been established for several decades (for review see [58]), the role of these proteins in reducing cardiac ischemia and reperfusion damage was not described before 1988 [17]. Postischemic cardiac mechanical function was found to be improved in rats heat-shocked 24 hours earlier [17]. This publication can be considered a hallmark in the investigation of heat shock-mediated cardioprotection. During the last 8 years it has been demonstrated that heat shock-induced cardioprotection against ischemia is reproducible and can be observed in different types of animals $[17 ; 71 ; 120]$. Not only hyperthermic pretreatment but also other interventions inducing expression of HSPs, such as amphetamine [71], and endotoxines [11] administration, and ischemia itself $[16 ; 43 ; 66]$ result in improved postischemic cardiac function compared to non-treated controls. It was also established that hyperthermic pretreatment reduces infarct size $[19 ; 66 ; 68]$ and stunning in the reperfused myocardium [92]. Besides, the postischemic duration of arrhythmias [107] and the loss of intracellular enzymes [17; 120] were reduced, indicating that cellular membrane damage was mitigated.

Since the most inducible HSP in the heart is HSP72, the beneficial effects of pretreatment on postischemic mechanical function of the heart have been ascribed to increased expression of this protein. To provide exclusive evidence for this relationship, experiments have been performed with isolated cells transfected with the HSP72 gene [37; 95]. Recently, transgenic mice with a stable high expression of 
HSP72 have been developed $[65 ; 89]$. In the transfected cells as well as in the transgenic animals hypoxia or ischemic stress was better tolerated, and cardiac tissue could be protected efficiently by elevated levels of HSP72.

The mechanism underlying the protection of the heart against an ischemic insult by HSP72 is still incompletely understood. The most advanced theory is that the elevated amounts of HSP72 protein associate with proteins which are destabilized and/or denatured during ischemia [84; 85]. However, evidence for such a mechanism under in-vivo circumstances is still lacking. Until now, only limited quantitative data regarding the amounts of HSP72 present are available [99]. In the heart the levels of HSP72 induced by heat are estimated to be relatively low, i.e. $0.3 \%$ of the total protein content [72]. If this is true, the beneficial effects of HSP72 must be achieved through interaction with a limited and selected number of target proteins. It has also been postulated that the cardioprotection was related to a more efficient elimination of oxygen-derived free radicals. This hypothesis was based on the observation that 24 hours after hyperthermic treatment the endogenous activity of the scavenging enzymes catalase and superoxide dismutase was found to be significantly increased $[13 ; 17 ; 70]$. The increase in endogenous catalase activity was due to modulation of enzyme activity after heat shock [18]. Catalase may be one of the selected target proteins which are bound by HSP72 during stress. After the stress period, catalase may be released resulting in an increased total catalase activity. Another hypothesis proposes that the heat shock-mediated improvement of postischemic function is due to decreased cytosolic calcium accumulation after restoration of flow. This assumption is based on the observation that heat shock pretreatment leads to significantly lower postischemic calcium contents in the mitochondria and attenuation of a submaximal calcium paradox in isolated rabbit hearts $[67 ; 120]$. However, detailed studies on the intracellular calcium homeostasis in heat shocked cells have not been performed yet. It can not be excluded that heat shock-induced changes, such as alterations in cellular structure and metabolic processes [55; 81], contribute to the cardioprotective effect of hyperthermic pretreatment.

\section{Expression of HSPs in hypertrophied and aged hearts}

An increased hemodynamic load can be considered to represent an environmental stress for cardiac cells. Therefore, it is conceivable that HSPs are induced under these less favorable circumstances. Indeed, in rat hearts HSP72 is rapidly induced after aortic banding [21; 104]. Although the load to which the heart is exposed is permanent, HSP72 is transiently expressed and the protein can no longer be detected 7 to 21 days after aortic constriction. This suggests that a permanently increased hemodynamic load induces only a phasic HSP72-expression. The expression of HSP72 following whole body heat shock is significantly higher in hearts of adult spontaneously hypertensive rats than in adult normotensive rats [10]. This might be attributed to the higher thermosensitivity i.e. rate of body temperature increase in spontaneously hypertensive animals compared to normotensive controls [62].

During aging, in the cardiomyocyte transcription, translation and proteolysis are decreased, while the number of abnormal proteins is increased $[22 ; 27 ; 52]$. This could imply that the transcription and translation of HSPs are also affected. Indeed, the ability of cardiac cells to increase the expression of HSP72 decreases significantly with age $[10 ; 41]$. These findings strongly suggest that the aged heart is not as capable to respond to stressful situations as the young heart. 
Until now data on the ischemia tolerance of pathologically hypertrophied and aged hearts following heat shock are virtually lacking in literature. To enlarge our knowledge about this intriguing subject these aspects of heat shock-induced cardiac protection form the major part of the present thesis.

\section{Scope of the thesis}

The general aim of this thesis was to study the consequences of hyperthermic pretreatment on preischemic and postischemic mechanical function in adult and aged hypertrophied and non-hypertrophied rat hearts. The rat heart was used because it has been shown that heat shock-mediated cardioprotection is reproducible in this species and the pathological rat heart models employed have been well characterized and are available in our laboratories. To study mechanical function we used the isolated ejecting heart, a model further developed in our laboratories, because in this model left ventricular contractile function can be investigated under well controlled conditions [102; 113].

In the first series of experiments we investigated the effect of hyperthermic pretreatment on postischemic recovery in compensated hypertrophied hearts, because the pressure overloaded hypertrophied heart is known to have a decreased tolerance to ischemia. Possible causes of this reduced tolerance are postischemic subendocardial no-reflow and increased incidence of arrhythmias. We developed the hypothesis that hyperthermic pretreatment could limit postischemic subendocardial no-reflow and hence improve mechanical function. Therefore, we studied the effect of hyperthermic pretreatment on both preischemic and postischemic hemodynamic function in isolated ejecting hypertrophied rat hearts 24 hours following heat shock. Cardiac hypertrophy was induced 7 weeks earlier by suprarenal abdominal aorta banding. Special attention was paid to the effects of hyperthermic pretreatment on the postischemic duration of arrhythmias and on preischemic and postischemic regional myocardial flow, using radioactive microspheres (Chapter 2).

Because in the hypertrophied heart postischemic functional recovery can be positively affected by increasing coronary perfusion pressure, thereby mitigating subendocardial no-reflow, we investigated whether the combination of increased coronary perfusion pressure with hyperthermic pretreatment had additional beneficial effects on postischemic recovery of hypertrophied hearts (Chapter 3 ).

Due to long-standing hypertension in aged hearts the ischemia tolerance is even more depressed than in compensated hypertrophied hearts. Clinically this type of heart is encountered in a substantial number of patients subjected to cardiac surgery. The therapeutical potentials of hyperthermic pretreatment in this type of heart are unknown. Since it has been described that the magnitude of HSP72 induction is significantly lower in hypertrophied hearts of old than young animals $[10 ; 80]$, we hypothesized that the effects of hyperthermic pretreatment on the postischemic cardiac recovery of old (hypertensive) rats would be limited. Therefore, we studied preischemic and postischemic cardiac function in 16 months old aortic banded rat hearts 24 hours following hyperthermic pretreatment. The results of this study are presented in Chapter 4.

One of the most striking features of hyperthermic pretreatment is that improvement of postischemic cardiac function is not observed before 24 hours after pretreatment, despite the fact that HSP72 is already expressed in myocardial tissuue 6 hours after heat shock. Detailed information on the hemodynamic behavior of the non-hypertrophied heart during the first 24 hours following heat shock is 
limited. It has only been shown that ischemia tolerance is not improved immediately following heat shock [49], which contrasts with the results obtained by ischemic preconditioning, in which protection is observed within the first hours following the short ischemic episodes [51]. After hyperthermic pretreatment, it is known that HSP72 is expressed rapidly and that maximal protein levels in normal cardiac tissue can be detected within 6 hours after heat shock [18]. Since it has been postulated that the degree of improvement of postischemic function correlates with the amount of HSP72 present in the tissue [44; 68], it is conceivable that the beneficial effects of hyperthermic pretreatment are also present within a few hours following heat shock. Therefore, we investigated in detail the preischemic and postischemic cardiac performance in normal isolated hearts of adult rats at various time-intervals within the first 24 hours following heat shock. To relate cardiac performance to the expression of HSP72, we investigated the HSP72 and HSP73 mRNA levels in these hearts. The results of this study are described in Chapter 5.

Since we were able to show that heat shock pretreatment conferred cardioprotection in the adult hypertrophied and non-hypertrophied rat heart [13], we tried to get more insight into the possible mechanism(s) by which heat shock improves cardiac function after ischemia. Other studies have shown that heat shock-mediated protection was associated with lesser calcium content in the mitochondria upon reperfusion $[17 ; 120]$. As calcium likely plays a crucial role in ischemia/ reperfusion-induced cardiac damage on the one hand and in the mechanism underlying the effects of heat shock on the other the role of calcium was investigated through exposing isolated heat-shocked hearts to different extracellular calcium concentrations and different coronary perfusion pressures during the preischemic as well as postischemic perfusion phase (Chapter 6).

Since the results of these investigations indicated that calcium homeostasis was indeed altered in the heat-shocked heart we investigated calcium handling in more detail. To this end, we studied the response of single cardiomyocytes isolated from heat-shocked rats to calcium overload and pacing. Furthermore, calcium sensitivity towards the contractile apparatus was studied in heat stressed cardiomyocytes (Chapter 7). The thesis is concluded with a general discussion (Chapter 8).

\section{LITERATURE}

1. Alberts, B., D. Bray, J. Lewis, M. Raff, K. Roberts and J. Watson, (Eds). (1994) In: Molecular biology of the cell. New York, Garland Publishing. pp 566-567.

2. Anderson, P., S. Digerness and J. Vaughan. Hypertrophied hearts have diminished adenosine triphosphate recovery following ischemic injury as determined by nuclear magnetic resonance spectroscopy. Circ 78 (supll II): 535-543, 1988.

3. Anversa, P. and J. Capasso. Cellular basis of aging in the mammalian heart. Scan Microsc 5: 1065-1074, 1991.

4. Apstein, C., P. Menasche and B. Lorell. Hypoxia, ischemia, and the hypertrophied myocardium: basic medical and surgical considerations. In: Research in cardiac hypertrophy and fuilure. Wilts, England., John Libby \& Company Ltd. Pp 65-87, 1990.

5. Arrigo, A., J. Suhan and W. Welch. Dynamic changes in the structure and intracellular locale of the mammalian low-molecular-weight heat shock protein. Mol Cell Biol 8: 5059-5071, 1988.

6. Beckmann, R., L. Mizzen and W. Welch. Interaction of HSP70 with newly synthesized proteins: implications for protein folding and assembly. Science 248: 850-854, 1990.

7. Benndorf, R., K. Hayeß, S. Ryazantsev, M. Wieske, J. Behlke and G. Lutsch. Phosphorylation and supramolecular organization of murine small heat shock protein HSP25 abolish its actin polymerization-inhibiting activity. J Biol Chem 269: 20780-20784, 1994. 
8. Bolli, R. Mechanisms of myocardial "stunning". Circulation 82: 723-738, 1990.

9. Bond, U. and M. Schlesinger. Ubiquitin is a heat shock protein in chicken embryo fibroblasts. Mol Cell Biol 5: 949-956, 1985.

10. Bongrazio, M., L. Comini, G. Gaia, T. Bachetti and R. Ferrari. Hypertension, aging, and myocardial synthesis of heat shock protein 72. Hypertension 24: 620-624, 1994.

11. Brown, J., M. Grosso, L. Terada, G. Whitman, A. Banerjee, C. White, A. Harken and J. Repine. Endotoxin pretreatment increases endogenous myocardial catalase activity and decreases reperfusion injury of isolated rat hearts. Proc Natl Acad Sci USA 86: 2516-2520, 1989.

12. Cooley, D., G. Reul and D. Wukash. Ischemic contracture of the heart: "stone heart". Am I Cardiol 29: 575-577, 1972.

13. Cornelussen, R., W. Spiering, J.H.G. Webers, L.G. de Bruin, R.S.. Reneman, G.J. van der Vusse and L.H.E.H. Snoeckx. Heat shock improves the ischemic tolerance of the hypertrophied rat heart. Am J Physiol 267: H1941-H1947, 1994.

14. Craig, E., J. Kramer, J. Shilling, M. Werner-Washbume, S. Holmes, S. Kosic-Smither and C. Nicolet. SSC1, an essential member of the $S$. cerevisiae HSP70 multigene family, encodes a mitochondrial protein. Mol Cel Biol 9: 3000-3008, 1989.

15. Crête, P. and J. Landry. Induction of HSP27 phosphorylation and thermoresistence in chinese hamster cells by arsenite, cycloheximide, A23187, and EGTA. Radiat Res 121: 320-327, 1990.

16. Currie, R.W. Protein synthesis in perfused rat hearts after in vivo hyperthermia and in vitro cold ischemia. Biochem Cell Biol 66: 13-19, 1988.

17. Currie, R.W., M. Karmazyn, M. Kloc and K. Mailer. Heat-shock response is associated with enhanced post-ischemic recovery. Circ Res 63: 543-549, 1988.

18. Currie, R.W. and R.M. Tanguay. Analysis of RNA for transcripts for catalase and SP71 in rat hearts after in vivo hyperthermia. Biochem Cell Biol 69: 375-82, 1991.

19. Currie, R. W., R. M. Tanguay and J. J. Kingma. Heat-shock response and limitation of tissue necrosis during occlusion/reperfusion in rabbit hearts. Circulation 87: 963-71, 1993.

20. de Jong, W., J. Leunissen and C. Voorter. Evolution of the alfa-crystallin/small heat shock protein family. Mol Biol Eool 10: 103-126, 1993.

21. Delcayre, C., J.-L. Samuel, F. Marotte, M. Best-Belpomme, J. Mercadier and L. Rappaport. Synthesis of stress proteins in rat cardiac myocytes 2-4 days after imposition of hemodynamic overload. / Clin Invest 82: 460-468, 1988.

22. Dice, J. Cellular and molecular mechanisms of aging. Physiol Rev 73: 149-159, 1993.

23. Downey, J. Ischemic preconditioning. Nature's own cardioprotective intervention. Trends Cardiovasc Med 2: 170-176, 1992.

24. du-Toit, E. and L. Opie. Modulation of severity of reperfusion stunning in the isolated rat heart by agents altering calcium flux at onset of reperfusion. Circ Res 70: 960-967, 1992.

25. Ellis, R. and S. van der Vies. Molecular chaperones. Annu Rev Biochem 60: 321-347, 1991.

26. Flameng, W., W. Daenen, M. Borgers, F. Thonè, R. Xhonneux, A. van de Water and $H$. van Belle. Cardioprotective effects of lidoflazine during 1-hour normothermic global ischemia. Circ 64 797-807, 1981.

27. Folkow, B. and A. Svanborg. Physiology of cardiovascular aging. Physiol Reo 73: 725-764, 1993.

28. Garlick, P., M. Davies, D. Hearse and T. Slater. Direct detection of free radicals in the reperfused rat heart using electron spin resonance spectroscopy. Circ Res 61: 757-760, 1987.

29. Gerner, E. and M. Schneider. Induced thermal resistence in HeLa cells. Nature 256: 500-502, 1975.

30. Gething, M. and J. Sambrook. Protein folding in the cell. Nature 355: 33-45, 1992.

31. Gottesman, S. and M. Maurizi. Regulation by proteolysis: Energy-dependent proteases and their targets. Microbiol Reo 56: 592-621, 1992.

32. Grinwald, P. Calcium uptake during post-ischemic reperfusion in the isolated rat heart. / Mol Cell Cardiol 14: 359-365, 1982.

33. Guidon jr, P. and L. Hightower. Purification and initial characterization of the 71-kilodalton rat heat shock protein and its cognate as fatty acid binding proteins. Biochemistry 25: 3231$3239,1986$.

34. Gupta, R. and B. Singh. Cloning of the HSP70 gene from Halobacterium marismortui: relaedness of archaebacterial HSP70 to its eubacterial homologs and a model for the evolution of the HSP70 gene. J Bacteriol 174: 4594-4605, 1992.

35. Haas, I. and M. Wable. Immunoglobulin heavy chain binding protein. Nature 306: 387-389, 1983.

36. Harrison, G., H. Drabkin, F. Kao, I. Hart, E. Chu, B. Wu and R. Morimoto. Chromosomal location of human genes encoding major heat shock protein HSP70. Som Cell Mol Gen 13: 119-130, 1987. 
37. Heads, R., D. Latchman and D. Yellon. Stable high level expression of a transfected human HSP70 gene protects a heart-derived muscle cell line against thermal stress. J Mol Cell Cardiol 26: 695-699, 1994.

38. Hearse, D. Ischemia, reperfusion and the determinants of tissue injury. Cardiovasc Drugs Ther 4: 767-776, 1990.

39. Hearse, D., M. Braimbridge and P. Jynge. Protection of the ischemic myocardium. In: Cardioplegia. New York, Raven Press. 1981.

40. Hearse, D. and A. Tosaki. Free radicals and reperfusion-induced arrhythmias: Protection by spin trap agent PBN in the rat heart. Circ Res 60: 375-383, 1987.

41. Heydari, A., B. Wu, R. Takahashi, R. Strong and A. Richardson. Expression of heat shock protein 70 is altered by age and diet at the level of transcription. Mol Cell Biol 13: 2909-2918, 1993.

42. Hightower, L. Heat shock, stress proteins, chaperons, and proteotoxicity. Cell 66: 191-197, 1991.

43. Howard, G. and T. Geoghegan. Altered cardiac tissue gene expression during acute hypoxic exposure. Mol Cell Biochem 69: 155-160, 1986.

44. Hutter, M. M., R. E. Sievers, V. Barbosa and C. L. Wolfe. Heat-shock protein induction in rat hearts. A direct correlation between the amount of heat-shock protein induced and the degree of myocardial protection. Circulation 89: 355-60, 1994.

45. Jennings, R. and K. Reimer. Lethal myocardial ischemic injury. Am J Pathol 102: 241-255, 1981.

46. Jennings, R. and K. Reimer. Factors involved in salvaging ischemic myocardium: effect of reperfusion of arterial blood. Circ 68 (Suppl): I-25-I-36, 1983.

47. Jolly, S., W. Kane, M. Bailie, G. Abrams and B. Lucchesi. Canine myocardial reperfusion injury. Its reduction by the combined administration of superoxide dismutase and catalase. Circ Res 54 : 277-285, 1984.

48. Kang, P., J. Osterman, J. Shiling, W. Neupert, E. Craig and N. Pfanner. Requirement for HSP70 in the mitochondrial matrix for translocation of precursor proteins. Nature 348: 137-142, 1990.

49. Karmazyn, M., K. Mailer and R..W. Currie. Acquisition and decay of heat-shock-enhanced post-ischemic ventricular recovery. Am J Physiol 259: H424-H431, 1990.

50. Kendall, M. and R. Horton. Are calcium antagonists cardioprotective. J Royal Coll Physicians 19: 85-89, 1985.

51. Kuzuya, T., A. Hoshida, N. Yamashita. Delayed effects of sublethal ischemia on the acquisition of tolerance to ischemia. Circ Res 72: 1293-1299, 1993.

52. Lakatta, E. and F. Yin. Myocardial aging: functional alteration and related cellular mechanisms. Am / Physiol 11: H927-H941, 1982.

53. Landry, J., P. Chrétien, H. Lambert, E. Hickey and L. Weber. Heat shock resistance conferred by expression of the human HSP27 gene in rodent cells. J Cell Biol 109: 7-15, 1989.

54. Langer, T., C. Lu, H. Echols, J. Flanagan and M. Hayer. Successive action of DnaK, DnaJ, and GroEL along the pathway of chaperone-mediated protein folding. Nature 356: 683-689, 1992.

55. Laszlo, A., T. Davidson, A. Hu, J. Landry and J. Bedford. Putative determinants of the cellular response to hyperthermia. Int J Radiat Biol 63: 569-581, 1993.

56. Lee, A. Coordinated regulation of a set of genes by glucose and calcium ionophores in mammalian cells. Trends Biochem Sci 12: 20-23, 1987.

57. Li, G. and Z. Werb. Correlation between synthesis of heat shock proteins and development of thermotolerance in Chinese hamster fibroblasts. Proc Natl Acad Sci USA 79: 3516-3520, 1982.

58. Lindquist, S. The heat-shock response. Annu Reo Biochem 55: 1151-1191, 1986.

59. Lindquist, S. and E. Graig. The heat shock proteins. Annu Rev Biochem 22: 631-677, 1988.

60. Lis, J. and C. Wu. Transcriptional regulation of heat shock genes. In: Transcription: Mechanisms and regulation. New York, Raven Press. 459-475, 1994.

61. Longo, F. and Wang. cDNA cloning and expression of stress-inducible rat HSP70 in normal and injured rat brain. / Neuroscience Res 36: 325-335, 1993.

62. Malo, D., G. Schlager, J. Tremblay and P. Hamet. Thermosensitivity, a possible new locus involved in genetic hypertension. Hypertension 14: 121-128, 1989.

63. Manning, A. and D. Hearse. Reperfusion-induced arrhythmias: Mechanisms and prevention. J Mol Cell Cardiol 16: 497-518, 1984.

64. Manning-Krieg, U., P. Schemer and G. Schatz. Sequential action of mitochondrial chaperones in protein import into the matrix. EMBO f 10: 3273-3280, 1991.

65. Marber, M.S., R. Mestril, S.-H. Chi, M. Sayen, D.M. Yellon and W. Dillmann. Overexpression of the rat inducible 70-kD heat stress protein in a transgenic mouse increases the resistance of the heart to ischemic injury. I Clin Invest 95: 1446-1456, 1995. 
66. Marber, M.S., D.S. Latchman, J.M. Walker and D.M. Yellon. Cardiac stress protein elevation 24 hours after brief ischemia or heat stress is associated with resistance to myocardial infarction. Circulation 88: 1264-72, 1993.

67. Marber, M.S., J.M. Walker, D.S. Latchman and D.M. Yellon. Attenuation by heat stress of a submaximal calcium paradox in the rabbit heart. / Mol Cell Cardiol 25: 1119-1126, 1993.

68. Marber, M.S., J.M. Walker, D.S. Latchman and D.M. Yellon. Myocardial protection after whole body heat stress in the rabbit is dependent on metabolic substrate and is related to the amount of the inducible 70-kD heat stress protein. / Clin Invest 93: 1087-1094, 1994.

69. Martin, J., P. Geromanos, P. Tempst and F. Hartl. Identification of nucleotide-binding regions in the chaperonin proteins GroEL and GroES. Nature 366: 279-282, 1993.

70. Maulik, N., R. Engelman, Z. Wei, X. Liu, J. Rousou, J. Flack, D. Deaton and D. Das. Drug-induced heat shock preconditioning improves postischemic recovery after cardiopulmonary bypass. Circ 92 (supll I): II-381-II-388, 1995.

71. Maulik, N., Z. Wei, X. Liu, R. Engelman, J. Rousou and D. Das. Improved postischemic ventricular functional recovery by amphetamine is linked with its ability to induce heat shock. Mol Cell Biochem 137: 17-24, 1994.

72. McCully, J., T. Myrmel, M. Lotz, I. Krukenkamp and S. Levitsky. The rapid expression of myocardial HSP70 mRNA and the heat shock $70 \mathrm{kDa}$ protein can be achieved after only a brief period of retrograde hyperthermic perfusion. I Mol Cell Cardiol 27: 873-882, 1995.

73. Mehlen, P., X. Preville, P. Chareyon, J. Briolay, R. Klemenz and A.-P. Arrigo. Constitutive expression of human HSP27, Drosophila HSP27, or human alphaB-crystallin confers resistance to TNF-and oxidative stress-induced cytotoxity in stable transfected murine L929 fibroblasts. J Immunol 154: 363-374, 1995.

74. Merck, K., P. Groenen, C. Voorter, W. de Haard-Hoekman, J. Horwitz, H. Bloemendal and W. de Jong. Structural and functional similarities of bovine alfa-crystallin and mouse small heat shock protein. A family of chaperones. / Biol Chem 268: 1046-1052, 1993.

75. Milarski, K. and R. Morimoto. Mutational analysis of the human HSP70 protein: distinct domains for nucleolar localization and adenosine triphosphate binding. / Cell Biol 109: 1947$1962,1989$.

76. Mizzen, L. and W. Welch. Characterization of the thermotolerant cell. 1. Effects of heat shock on protein synthesis activity and the regulation of heat shock protein 70 expression. / Cell Biol 106: 1105-1116, 1988.

77. Morimoto, R. Heat shock: The role of transient inducible responses in cell damage, transformation, and diffrentiation. Cancer Cells 3: 295-301, 1991.

78. Munro, S. and H. Pelham. A C-terminal signal prevents secretion of luminal ER proteins. Cell 48: 899-907, 1987.

79. Nadeau, K., A. Das and C. Walsh. HSP90 chaperonins possess ATPase activity and bind heat shock transcription factors and peptidyl propyl isomerases. / Biol Chem 268: 1479-1487, 1993.

80. Nitta, Y., K. Abe, M. Aoki, I. Ohno and S. Isoyama. Diminished heat shock protein $70 \mathrm{mRNA}$ induction in aged rats after ischemia. Am / Physiol 267: H1795-H1803, 1994.

81. Nover, L. (1991) Heat shock response. In: Heat shock response. Boca Raton (Floridd), CRC press.

82. Opie, L. Reperfusion injury and its farmacological modification. Circulation 80: 1049-1062, 1989.

83. Palleros, D., K. Reid, L. Shi, W. Welch and A. Fink. ATP-induced protein-HSP70 complex dissociation reguires K+ but not ATP hydrolysis. Nature 365: 664-666, 1993.

84. Palleros, D., L. Shi, K. Reid and A. Fink. HSP70-protein complexes. J Biol Chem 269: 1310713114, 1994.

85. Palleros, D., W. Welch and A. Fink. Interaction of HSP70 with unfolded proteins. Effects of temperature and nucleotides on the kinetics of binding. Proc Natl Acad Sci 88: 5719-5723, 1991.

86. Pardue, M., D. Ballinger and N. Hogan. The heat shock response. Cells coping with transient stress. Annals of the New York Academy of Sciences 664: 125-139, 1993.

87. Parsell, D. and S. Lindquist. The function of heat shock proteins in stress tolerance: degradation and reactivation of damaged proteins. Annu Rev Genet 27: 437-496, 1993.

88. Parsell, D., J. Taulien and S. Lindquist. The role of heat shock proteins in thermotolerance. Philos Trans R Soc London Ser B 339: 279-286, 1993.

89. Plumier, C.L.., B. Ross, R.W. Currie, C. Angelidis, H. Kazlaris, G. Kollias and G.N. Pagoulatos. Transgenic mice expressing the human heat shock protein 70 have improved post-ischemic myocardial recovery. I Clin Invest 95: 1854-1860, 1995.

90. Riabowol, K., L. Mizzen and W. Welch. Heat shock is lethal to fibroblasts microinjected with antibodies against hsp70. Science 242: 433-436, 1988. 
91. Ritossa, F. A new puffing pattern induced by a temperature shock and DNP in Drosophila. Experientia 18: 571-573, 1962.

92. Robinson, B., T. Morita, D. Toft and J. Morris. Accelerated recovery of postischemic stunned myocardium after induced expression of heat shock protein (HSP70). I Thorac Cardiowasc Surg 109: 753-764, 1995.

93. Rothman, J. Polypeptide chain binding proteins: catalysts of protein folding and related processes in cells. Cell 59: 591-601, 1989.

94. Sanchez, Y. and S. Lindquist. HSP104 required for induced thermotolerance. Science 248: 1112$1115,1990$.

95. Sanders Williams, R., J. Thomas, M. Fina, Z. German and I.J. Benjamin. Human heat-shock protein 70 (hsp70) protects murine cells from injury during metabolic stress. J Clin Invest 92: 503$508,1993$.

96. Schlafer, M., P. Kane and M. Kirsh. Superoxide dismutase plus catalase enhances the efficacy of hypothermic cardiolplegia to protect the globally ischemic, reperfused heart. I Thorac Cardiovasc Surg 83: 830-839, 1982.

97. Schlesinger, M. Heat-shock proteins. J Biol Chem 265: 12111-12114, 1990.

98. Schlesinger, M., M. Ashburner and A. Tissieres, (Eds) (1982). Heat shock from bacteria to man. New York, Cold Spring Harbor Laboratory.

99. Skidmore, R., J. Gutierrez, V. Guerriero Jr and K. Kregel. HSP70 induction during exercise and heat stress in rats: role of internal temperature. Am / Physiol (Regulatory Integratioe Comp Physiol 37) 268: R92-R97, 1995.

100. Snoeckx, L.H.E.H, G.J. van der Vusse, W. Coumans and R.S. Reneman. The effects of global ischemia and reperfusion on compensated hypertrophied hearts of aortabanded rats. / Mol Cell Cardiol 22: 1439-1451, 1990.

101. Snoeckx, L.H.E.H, G.J. van der Vusse, W. Coumans, P.H.M. Willemsen and R.S. Reneman. Differences in ischemia tolerance between hypertrophied hearts of adult and aged spontaneously hypertensive rats. Cardiovasc Res 27: 874-881, 1993.

102. Snoeckx, L.H.E.H., G.J. van der Vusse, W. Coumans, P.H.M. Willemssen, T. van der Nagel and R.S. Reneman. Myocardial function in normal and spontaneously hypertensive rats during reperfusion after aperiod of global ischemia. Cardiovasc Res 20: 67-75, 1986.

103. Snoeckx, L.H.E.H., G.J. van der Vusse, F. van der Veen, W. Coumans and R.S. Reneman. Recovery of hypertrophied rat hearts after global ischemia and reperfusion at different perfusion pressures. Europ J Physiol (Pflugers Arch) 413: 303-312, 1989.

104. Snoeckx, L.H.E.H., F. Contard, J. L. Samuel, F. Marotte and L. Rappaport. Expression and cellular distribution of heat-shock and nuclear oncogene proteins in rat hearts. Am J Physiol H1443-H1451, 1991.

105. Sorger, P. and H. Pelham. Cloning and expression of a gene encoding hsc73, the major hsp70-like protein in unstressed rat cells. EMBO / 6: 993-998, 1987.

106. Sorger, P. and H. Pelham. The glucose-regulated protein GRP94 is related to the heat shock protein HSP90. J Mol Biol 194: 341-344, 1987.

107. Steare, S.E. and D.M. Yellon. The protective effect of heat stress against reperfusion arrhythmias in the rat. J Mol Cell Cardiol 25: 1471-1481, 1993.

108. Stevenson, M. and S. Calderwood. Members of the 70-kilodalton heat shock protein family contain a highly conserved calmoduline-binding domain. Mol Cell Biol 10: 1234-1238, 1990.

109. Su, C., W. Dillmann, W. Woods and O. Owen. Heat shock induced tolerance in muscle cells (Abstract). Circ 86: (suppl 1): 33, 1992.

110. Subjeck, J., T. Shyy, J. Shen and R. Johnson. Association between the mammalian 110.000 dalton heat shock protein and nucleoli. J cell Biol 97: 1389-1395, 1983.

111. Theodorakis, N. and R. Morimoto. Pusttranscriptional regulation of hsp70 expression in human cells: Effects of het shock, inhibition of protein synthesi, and adenovirus infection on translation and mRNA stability. Mol Cel Biol 7: 4357-4368, 1987.

112. Tissières, A., H. Mitchell and U. Tracy. Protein synthesis in salivary glands of Drosophila melanogaster. J Mol Biol 84: 389-398, 1974.

113. Van Bilsen, M., L.H.E.H. Snoeckx, T. Arts, G.J. van der Vusse and R.S. Reneman. Performance of the isolated, ejecting heart: Effects of aortic impedance and exogenous substrates. Pflugers Arch 419: 7-12, 1991 .

114. Vierling, E. The roles of heat shock proteins in plants. Annu Reo Plant Physiol 42: 579-620, 1991. 
115. Watts, J., L. Maiorano and P. Maiorano. Comparison of the protective effects of verapamil, diltiazem, nifedipine, and buffer containing low calcium upon global myocardial ischemic injury. J Mol Cell Cardiol 18: 255-263, 1986.

116. Welch, W. Mammalian stress response: Cell physiology, structure/function of stress proteins, and implications for medicine and disease. Physiol Rev 72: 1063-1081, 1992.

117. Welch, W. and J. Feramisco. Nuclear and neonuclear localization of the 72.000 dalton heatshock protein in heat-shocked mammalian cells. J Biol Chem 259: 4501-4513, 1984.

118. Welch, W. and J. Suhan. Morphological study of the mammalian stress response: Charaterization of changes in cytoplasmic organelle, cytoskeleton, and nucleoli, and the appearence of intranuclear actin filaments in rat fibroblasts after heat shock treatment. J Biol Chem 101: 1198-1211, 1985.

119. Welch, W. and J. Suhan. Cellular and biochemical events in mammalian cells during and after recovery of stress. J Biol Chem 103: 2035-2052, 1986.

120. Yellon, D.M., E. Pasini, A. Cargnoni, M.S. Marber, D. Latchman and R. Ferrari. The protective role of heat stress in the ischaemic and reperfused rabbit myocardium. J Mol Cell Cardiol 24: 895-907, 1992.

121. Yellon, D.M., D.S. Latchman and M.S. Marber. Stress proteins -an endogenous route to myocardial protection: fact or fiction? Cardiovasc Res 27: 158-161, 1993. 


\section{Chapter 2}

\section{HEAT-SHOCK IMPROVES THE ISCHEMIA TOLERANCE OF THE HYPERTROPHIED RAT HEART}

This study was published as

"Heat shock improves the ischemia tolerance of the hypertrophied rat heart"

by R. Cornelussen, W. Spiering, J.H.G. Webers, L. de Bruin, G.J. van der Vusse, R.S. Reneman and L.H.E.H. Snoeckx in Am. J. Phyiol. 267 (Heart Circ. Physiol. 36): H1941-1947, 1994. 


\section{ABSTRACT}

The postischemic recovery of hypertrophied hearts was studied 24 hours after total body hyperthermia. To this end, heat-shock was applied to anesthetized aortabanded (AobHS) and sham-operated (Sham ${ }_{H S}$ ) rats. Cardiac hypertrophy was induced 8 weeks earlier. In isolated ejecting hearts, functional recovery after $45 \mathrm{~min}$ of global ischemia was poor and moderate in non-heated hypertrophied (AobC) and non-hypertrophied (Sham $\mathrm{C}$ ) hearts. Heat-shock significantly improved postischemic recovery in both AobHS and ShamHS hearts. This improvement of functional recovery was associated with a significant reduction of the duration of arrhythmias. Besides, coronary flow was significantly higher in both types of heatshocked hearts than in the corresponding control hearts during the preischemic as well as the postischemic period. Postischemic endocardial flow, assessed by radioactive microspheres, was significantly improved in AobHS hearts. Compared to the corresponding control hearts, the native endogenous catalase activity was not changed in the Aob HS hearts, but was significantly increased in ShamHS hearts. The present findings suggest that the postischemic functional improvement after total body hyperthermia can be explained by increased and more homogeneous myocardial perfusion, which may also reduce the duration of postischemic arrhythmias. This effect is especially beneficial for the hypertrophied heart, which is known to be extremely vulnerable to the ischemic insult, probably caused by subendocardial underperfusion.

\section{INTRODUCTION}

When isolated cells, tissues or whole organisms are exposed to elevated ambient temperatures, they respond by the immediate expression of a number of highly conserved proteins, the so-called stress or heat-shock proteins (HSP's) (for review see 22). In the heart, stress or heat-shock induces the expression of multiple members of different HSP-families, like the small HSP $27 \mathrm{kDa}$ [6], the $58 \mathrm{kDa}$ HSP [18], the highly inducible HSP $72 \mathrm{kDa}[10,23]$, and the HSP $90 \mathrm{kDa}$ [22]. Depending on the organism, the induced expression of these proteins may be associated with a transient protection against a subsequent normally lethal heat-shock (thermotolerance), and against oxidative or ischemic stresses [21]. In the heart, it has also been shown that heat-shock pretreatment enhances ex-vivo postischemic functional recovery $[8,31]$ and limits infarct size in-vivo [9].

The hypertrophied heart is known to be highly vulnerable to ischemic damage [26]. Although the mechanism underlying this phenomenon is incompletely understood, postischemic reperfusion of the hypertrophied myocardium is known to be associated with persistent underperfusion of the subendocardial layers of the left ventricle, especially when the hearts are perfused at relatively low coronary perfusion pressures [26]. Postischemic subendocardial underperfusion and, hence, postischemic recovery can be significantly improved by increasing coronary perfusion pressure. At this pressure level, however, the hypertrophied heart has to perform at a higher load, enhancing the oxygen demand of the already compromised myocardium. Therefore, it would benefit the postischemic hypertrophied heart when postischemic subendocardial perfusion, and hence, recovery could be improved without enhancing the load on the heart.

A preliminary study in our laboratory has shown that total body hyperthermia induces a significant elevation of coronary flow in both the 
hypertrophied and non-hypertrophied rat heart [7]. This observation has led us to the hypothesis that total body hyperthermia may protect the heart, and in particular the hypertrophied heart, against functional loss following the ischemic insult by improving preischemic and postischemic myocardial perfusion. To test this hypothesis rats with hypertrophied and non-hypertrophied hearts were exposed to a sublethal heat-shock 24 hours prior to isolated heart perfusion. Comparable groups with non-heated hypertrophied and non-hypertrophied hearts served as controls. The isolated hearts were exposed to a period of global ischemia. Postischemic functional recovery was assessed by determining the percentage recovery, calculated as the ratio of the maximally attained postischemic to preischemic values of hemodynamic variables like cardiac output, left ventricular developed pressure, and maximum positive and negative left ventricular $\mathrm{dP} / \mathrm{dt}$. The endocardial to epicardial flow distribution was evaluated with the use of radioactive microspheres during both the preischemic and postischemic perfusion period. The loss of lactate dehydrogenase (LDH) and creatine kinase (CK) was determined to assess ischemia/reperfusion-induced cell injury. We also determined the myocardial catalase activity, because it has been postulated that this enzyme, as hydroxyl radical scavenger, may play a role in the protective effect of heat-shock pretreatment $[5,8]$.

\section{MATERIALS AND METHODS}

\section{Animal preparation}

The experiments were performed on 14-15 weeks old male Lewis rats. The animals were kept under restful housing conditions and had free access to food (Diet SRMA, Hope farms) and water. The rats were housed in temperature-controlled rooms on an artificial light cycle of 12 hours. Eight weeks earlier the animals were either aorta-banded (Aob) or sham-operated (Sham). All experiments were approved by the Institutional Animal Care and Use Committee of the University of Limburg.

\section{Aorta-banding}

Six to seven weeks old rats were anesthetized with Narcovet ${ }^{8}$ (pentobarbital 0.6 $\mathrm{mg} / \mathrm{g}$ i.p.). Under sterile conditions the abdominal aorta was isolated suprarenally via a lateral abdominal incision, and narrowed to about $40 \%$ of its original diameter by means of a Weck hemoclip [25]. In Sham-operated animals the aorta was only dissected free. The abdomen was closed in layers and the animals were allowed to recover. In total 75 rats were used in this study.

\section{Heat-shock protocol}

Eight weeks after surgery the rats were anesthetized with Hypnorm ${ }^{3}(0.01 \mathrm{mg} / 100 \mathrm{~g}$ body weight fentanyl plus $0.5 \mathrm{mg} / 100 \mathrm{~g}$ body weight fluanison s.c.) and placed on a temperature-controlled heating-pad until body temperature, which was

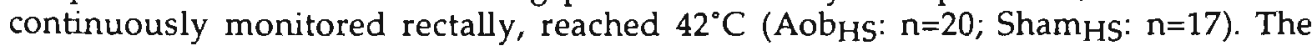
animals were kept at this temperature for $15 \mathrm{~min}$. Non-heat-shocked anesthetized animals followed the same protocol but were kept at normal ambient temperature (AobC: $n=20$; Sham $C: n=18$ ).

\section{Experimental groups}

Twenty-four hours following heat-shock or anesthesia the hemodynamic function before and after ischemia was evaluated in 4 groups of isolated, ejecting hearts 
(AobC: $n=15$; and AobHS: $n=14$; Shamc: $n=12$; ShamHS: $n=12$ ). In subsets of these groups the coronary flow distribution was evaluated using radioactive microspheres (AobC: $n=7$; and AobHS: $n=7$; Sham $\mathrm{C}$ : $n=6$; ShamHS: $n=6$ ). Native endogenous catalase activity and total protein content were measured in separate groups of hearts, perfused for only $5 \min \left(A_{C}: n=5\right.$; and Aob ${ }_{H S}: n=6$; Sham ${ }_{C}: n=6$; ShamHS: $n=5$ ).

\section{Heart preparation}

The animals were lightly anesthetized with Hypnorm ${ }^{\circledR}(0.01 \mathrm{mg} / 100 \mathrm{~g}$ body weight fentanyl plus $0.5 \mathrm{mg} / 100 \mathrm{~g}$ body weight fluanisone s.c.). After cervical dislocation the hearts were rapidly removed from the thorax and immediately immersed in an icecold Tyrode buffer solution, containing (in mmol/l): $\mathrm{NaCl}(130.0), \mathrm{KCl}(5.6), \mathrm{CaCl}_{2}$ (2.2), $\mathrm{MgCl}_{2}(1.0), \mathrm{NaH}_{2} \mathrm{PO}_{4}(1.2), \mathrm{NaHCO}_{3}(28.6)$ and $\mathrm{D}(+)$ glucose (11.1).

\section{Isolated heart perfusion}

The hearts were quickly trimmed from lung and fat tissue, weighed, and connected via the aorta to a perfusion apparatus installed in a thermostable cage $\left(37^{\circ} \mathrm{C}\right)$, as described earlier $[27,29]$. Retrograde perfusion was immediately started at a diastolic aortic pressure $\left(\mathrm{P}_{\mathrm{ao}}\right.$, diast $)$ of $8.0 \mathrm{kPa}$. The perfusion-buffer was continuously gassed with carbogen $\left(95 \% \mathrm{O}_{2}\right.$ and $5 \% \mathrm{CO}_{2} ; \mathrm{pO}_{2}>70 \mathrm{kPa} ; \mathrm{pH}$-range $\left.=7.32-7.45,37^{\circ} \mathrm{C}\right)$. The left atrium was connected to a second cannula so that the hearts could be allowed to eject fluid through the aortic valve. Left atrial filling pressure was set at $1.3 \mathrm{kPa}$. Aortic pressure was measured one $\mathrm{cm}$ above the aortic valve and left ventricular pressure $\left(\mathrm{P}_{\mathrm{lv}}\right)$ through the apex of the heart with a small polyethylene catheter connected to an external pressure transducer (Century Technology Company; Inglewood, USA). Left ventricular developed pressure (LVDP) was calculated as the difference between systolic and end-diastolic pressure (LVEP). Left ventricular performance and relaxation were respectively estimated from the positive and negative maximal first derivative of left ventricular pressure $\left(+\mathrm{dP} / \mathrm{dt}_{\max }\right.$ and $\left.-\mathrm{dP} / \mathrm{dt}_{\max }\right)$. The flow in the aortic cannula was measured with an extracorporeal flow probe (diameter $3 \mathrm{~mm}$ ) connected to an electromagnetic flowmeter (Skalar 601). Coronary flow (CF) was measured by timed collection of the coronary perfusate dripping from the heart. Cardiac output $(\mathrm{CO})$ was defined as the sum of aortic flow and coronary flow, and, by definition, was zero when the hearts were perfused in the retrograde way. All hemodynamic variables were fed into a computer allowing the on-line calculation and presentation of data [24]. Platinum electrodes were attached to the atrial and ventricular walls to record the electrograms. The hearts were electrically paced $(5 \mathrm{~Hz})$ throughout the experiment, except during ischemia and the first $10 \mathrm{~min}$ of reperfusion.

\section{Perfusion protocol}

After an initial stabilization period of $10 \mathrm{~min}$, during which the hearts were perfused in the retrograde way, the left atrial cannula was opened and the hearts were allowed to eject (antegrade perfusion). In all hearts the $P_{a o, d i a s t}$ was kept constant at $8.0 \mathrm{kPa}$. Under these conditions the systolic $P_{\mathrm{lv}}$ reached values of about $12 \mathrm{kPa}$. At the end of the $40 \mathrm{~min}$ preischemic period the hearts were subjected to 45 min global ischemia by crossclamping the left atrial and aortic cannulas. Pacing was stopped. After ischemia, the hearts were reperfused during $15 \mathrm{~min}$ in the retrograde way and $30 \mathrm{~min}$ in the antegrade way, at an identical $\mathrm{P}_{\mathrm{ao}}$,diast as during the preischemic period. The maximum steady state values attained during the 
antegrade preischemic and postischemic perfusion periods were used for calculation of the percentage recovery of the hemodynamic variables. Coronary effluent samples were immediately frozen in liquid nitrogen and stored at $-80^{\circ} \mathrm{C}$ for later biochemical analysis.

\section{Regional myocardial flow}

In the subsets of hearts regional myocardial flow was estimated, using radioactively labeled microspheres (NEN, about $15 \mu \mathrm{m}$ in diameter) as described by Snoeckx and colleagues [27]. To this end, during the preischemic period, and the beginning and the end of the reperfusion period, the perfusion of the heart was shortly turned to the retrograde mode and radioactive microspheres (approximately $5.10^{3}$ spheres. $\mathrm{g}^{-1}$ heart weight; either ${ }^{103} \mathrm{Ru},{ }^{113} \mathrm{Sn}$, or ${ }^{141} \mathrm{Ce}$ ) were injected into the aortic cannula. At the end of the experiment, hearts were weighed and stored in a $2.5 \%$ formaldehyde solution. The left ventricle was cut into 4 slices, each of which was divided into inner and outer layers. The radioactivity levels of the different tissue samples were determined using a Packard MultiChannel Analyzer, as described by Prinzen and co-workers [19]. The various tissue samples were weighed and flow distribution was calculated as the ratio between the left ventricular endocardial and epicardial flow values [27].

\section{Biochemical analysis}

The coronary effluent samples were monitored for the presence of lactate dehydrogenase (LDH) and creatine kinase (CK). Enzyme activities were measured spectrophotometrically according to Bergmeyer and Bernt, using a Cobas Bio autoanalyzer [3,4]. Myocardial catalase activity and total protein content were measured in hearts which were perfused for only $5 \mathrm{~min}$ to prevent contamination of the tissue with blood as the catalase activity in red blood cells is relatively high. After perfusion the hearts were freeze-clamped as described above. Native tissue catalase activity was determined following Aebi [1]. Total protein content was measured according to Lowry and co-workers [15].

\section{Statistics}

All values are expressed as mean values \pm s.e. Differences between groups were evaluated for statistical significance using the Mann-Whitney $U$ - test. Values of $\mathrm{p} \leq 0.05$ were considered to be statistically significant.

\section{RESULTS}

\section{Degree of hypertrophy}

The heart weight and heart weight to body weight ratios were significantly higher in both Aob than in both Sham groups, as aorta-banding resulted in a degree of hypertrophy of $25-27 \%$ (Table 1). Left ventricular hypertrophy was probably underestimated, since right ventricular and atrial weights were included in the calculation of total heart weight.

\section{Hemodynamics}

Preischemic values: Figure 1 shows the time-course of weight-related $C F$ in the 4 experimental groups. CF values were significantly higher in both heat-shocked than in the correponding control hearts and were respectively 15\% (AobHS) and $28 \%$ 
(ShamHS) enhanced. Table 2 shows representative steady-state values of all preischemic hemodynamic variables. No significant differences were observed between the values in the 4 groups.

Table 1: Heart weight (HW), body weight (BW) and heart weight to body weight ratio (HW/BW) in anesthetized (C) and heat-shocked (HS) aorta-banded (Aob) and shamoperated (Sham) rats.

\begin{tabular}{|c|c|c|c|}
\hline & $\begin{array}{l}\text { Heart weight } \\
\text { (g) }\end{array}$ & $\begin{array}{l}\text { Body weight } \\
\text { (g) }\end{array}$ & $\begin{array}{c}\mathrm{HW} / \mathrm{BW} \\
\left(10^{-2}\right)\end{array}$ \\
\hline Aobc $(n=20)$ & $1.73 \pm 0.03^{*}$ & $317 \pm 5$ & $0.545 \pm 0.010^{*}$ \\
\hline AobHS $(n=20)$ & $1.70 \pm 0.04^{*}$ & $320 \pm 5$ & $0.531 \pm 0.012^{*}$ \\
\hline Shamc $(n=18)$ & $1.38 \pm 0.02$ & $320 \pm 4$ & $0.430 \pm 0.004$ \\
\hline ShamHS $(n=17)$ & $1.34 \pm 0.03$ & $316 \pm 5$ & $0.423 \pm 0.004$ \\
\hline
\end{tabular}

Postischemic values: In the Aob $\mathrm{b}_{\mathrm{C}}$ group, postischemic reactive hyperemia was completely absent (Figure 1; upper panel). The mean level of CF obtained during the first 15 min of reperfusion (retrograde perfusion) was compared with the CF values obtained during freischemic retrograde perfusion, noted at $t=10 \mathrm{~min}$. In this initial reperfusion period, in AobC hearts CF was $30 \%$ lower as compared to the preischemic values. In the AobHs hearts, a slight flow excess of $4 \%$ was found. Throughout the whole reperfusion phase, significantly higher CF values were

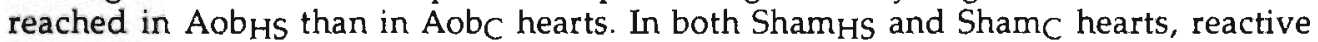
hyperemia was prominent during the initial reperfusion phase (Figure 1; lower panel). During the initial reperfusion phase in Shamc and ShamHS hearts, CF was found to be respectively $27 \%$ and $39 \%$ higher than during preischemic retrograde perfusion. Again, CF values were significantly higher in the Sham $\mathrm{ms}_{\mathrm{S}}$ than in the Shamc hearts throughout the whole reperfusion period.

Figure 2 shows the percentage recovery of the various hemodynamic variables. The recovery of $\mathrm{CO}$ was significantly better in Aob $\mathrm{HS}$ (51\% of the preischemic value) and Sham $\mathrm{HS}(76 \%)$ than in the corresponding control hearts. As for $\mathrm{CO}$, in both heat-shocked groups the postischemic recovery of LVDP (Aob HS: 83\%; ShamHS: $91 \%$ ), and $+\mathrm{dP}_{\mathrm{H}} / \mathrm{dt}_{\max }$ (AobHS: $74 \%$; Sham $\mathrm{HS}_{\mathrm{HS}}: 87 \%$ ) and $-\mathrm{dP}_{\mathrm{H}} / \mathrm{dt}_{\max }$ (AobHS: 74\%; ShamHS: $81 \%$ ) was significantly improved as compared to the recovery in the corresponding control groups. Besides, in the AobHS hearts the postischemic increase in LVEP was significantly reduced as compared to the AobC (from $54 \%$ to $13 \%$ ), while no significant differences were found between both groups of Sham hearts. In all 4 groups, the initial reperfusion phase was characterized by prominent electrical instability. Periods of atrial and ventricular fibrillation, during which mechanical function was absent, were alternated by periods of ventricular tachycardia or irregular rhythm associated with irregular mechanical activity. Commonly these periods ceased spontaneously during the reperfusion period in the non-hypertrophied heart. As shown in Table 3, the total 
duration of electrical instability was significantly reduced in both AobHS and ShamHS groups as compared to the corresponding control groups.
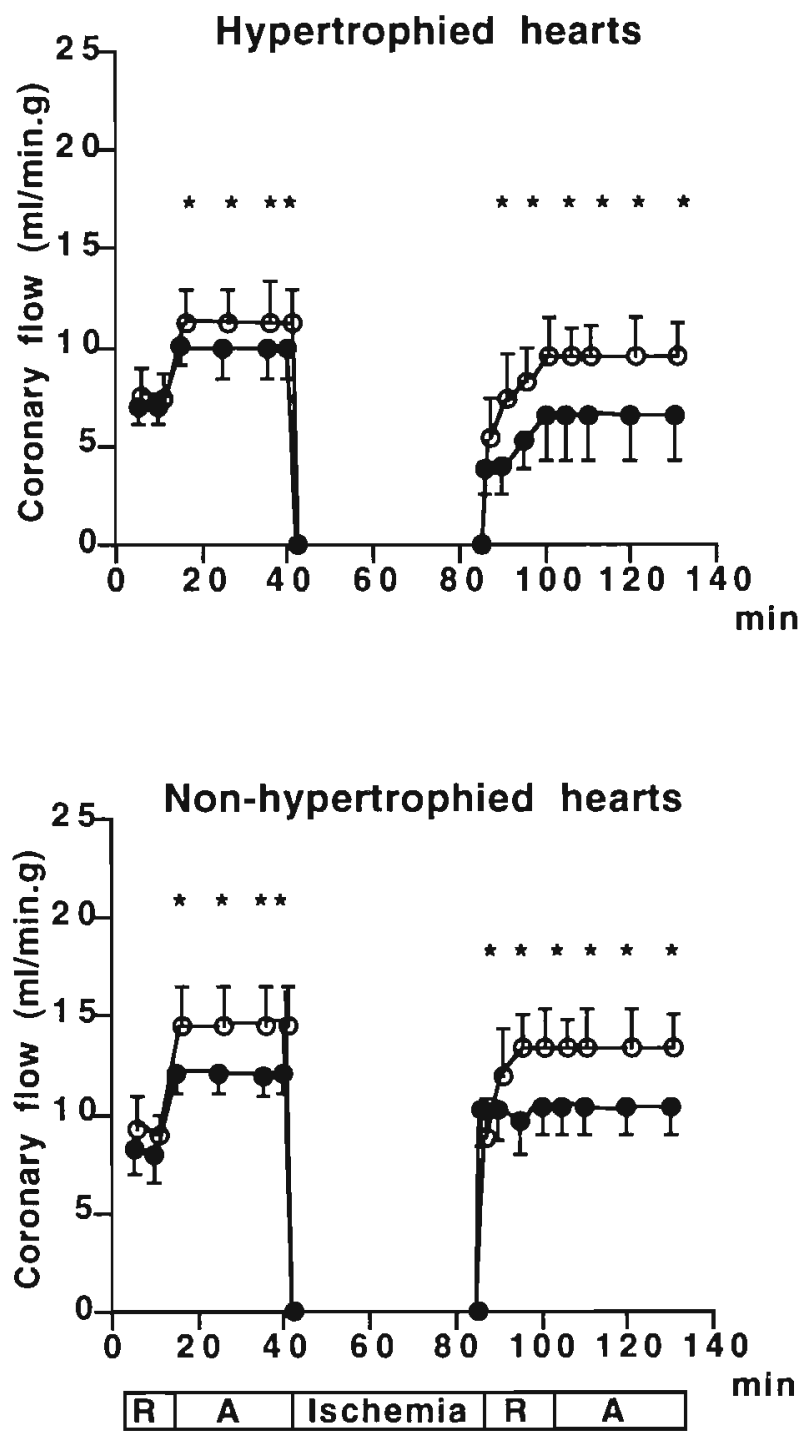

Figure 1: Weight related coronary flow before and after $45 \mathrm{~min}$ of global ischemia in heat-shocked (HS) and anesthetized (C) hypertrophied (Aob; upper panel) and non-hypertrophied (Sham; lower panel) rat hearts. Data are presented as mean \pm s.d. $R$, retrograde perfusion, $A$, antegrade perfusion. ": significantly different from the values in the corresponding control group. 
Table 2: Preischemic hernodynamic variables in hearts of anesthetized (C) and heatshocked (HS) aorta-banded (Aob) and sham-operated (Sham) rats.

\begin{tabular}{|c|c|c|c|c|}
\hline & $\begin{array}{c}\text { Aobc } \\
(n=15)\end{array}$ & $\begin{array}{l}\text { AobHS } \\
(n=14)\end{array}$ & $\begin{array}{l}\text { Shamc } \\
(n=12)\end{array}$ & $\begin{array}{c}\text { ShamHS } \\
(n=12)\end{array}$ \\
\hline $\begin{array}{l}\mathrm{CO}\left(\mathrm{ml} \cdot \mathrm{min}^{-1}\right) \\
\text { LVDP }(\mathrm{kPa}) \\
\text { LVEP }(\mathrm{kPa})\end{array}$ & $\begin{array}{l}75 \pm 3.0 \\
9.7 \pm 0.3 \\
2.4 \pm 0.1\end{array}$ & $\begin{array}{l}82 \pm 4.0 \\
9.5 \pm 0.3 \\
2.5 \pm 0.1\end{array}$ & $\begin{array}{l}81 \pm 3.0 \\
9.7 \pm 0.3 \\
2.3 \pm 0.1\end{array}$ & $\begin{array}{l}81 \pm 3.0 \\
9.7 \pm 0.3 \\
2.1 \pm 0.1\end{array}$ \\
\hline$+\mathrm{dP} / \mathrm{dt} \max \left(\mathrm{kPa} \mathrm{s}^{-1}\right)$ & $580 \pm 34$ & $518 \pm 46$ & $556 \pm 31$ & $517 \pm 12$ \\
\hline$-\mathrm{dP} / \mathrm{dt}_{\max }\left(\mathrm{kPa} \cdot \mathrm{s}^{-1}\right)$ & $306 \pm 19$ & $306 \pm 31$ & $332 \pm 17$ & $314 \pm 15$ \\
\hline
\end{tabular}

The data are expressed as mean values \pm s.e. $\mathrm{CO}=$ cardiac output, LVDP: left ventricular developed pressure, LVEP: left ventricular end-diastolic pressure, + /$\mathrm{dP} / \mathrm{dt}_{\max }$ : positive, respectively negative maximal first derivative of left ventricular pressure.

Table 3: Electrical behavior during 45 minutes of reperfusion following 45 minutes of ischemia in isolated hearts of anesthetized (C) and heat-shocked (HS) aorta-banded (Aob) and sham-operated (Sham) rats.

\begin{tabular}{lcccc}
\hline & $\begin{array}{c}\text { AobC } \\
(\mathrm{n}=15)\end{array}$ & $\begin{array}{c}\text { AobHS } \\
(\mathrm{n}=14)\end{array}$ & $\begin{array}{c}\text { ShamC } \\
(\mathrm{n}=12)\end{array}$ & $\begin{array}{c}\text { Sham } \\
(\mathrm{n}=12)\end{array}$ \\
$\begin{array}{l}\text { Duration (min) of } \\
\text { arrhythmias }\end{array}$ & $36.9 \pm 3.3^{\circ}$ & $17.7 \pm 3.6^{* 0}$ & $16.3 \pm 2.0$ & $-1.8 \pm 0.9^{*}$ \\
sinus rhythm & $8.1 \pm 3.3^{\circ}$ & $27.3 \pm 3.6^{* 0}$ & $28.7 \pm 2.0$ & $36.2 \pm 0.9^{*}$
\end{tabular}

The data are presented as mean values \pm s.e.; ${ }^{*}$ : significantly different from the values in the corresponding control group; 0 : significantly different from the values in the corresponding Sham group

In contrast to all hearts in the other groups, only 6 out of 15 hearts in the AobC group showed complete electrical stability within $45 \mathrm{~min}$ of reperfusion. The significantly improved functional recovery found in both heat-shocked groups was not associated with a significant reduction of either LDH or CK loss (see Table 4).

\section{Regional myocardial flow measurements}

Figure 3 presents the regional flow distribution as assessed in the various subgroups under investigation with the use of radioactive microspheres. In Aob $\mathrm{C}$ and Sham $\mathrm{C}$ hearts, preischemic coronary flow was equally distributed to the endocardial and epicardial layers of the left ventricle whereas in both heat-shocked groups a slight and non-significant superperfusion of the epicardial layers was found. After $10 \mathrm{~min}$ of reperfusion the endo/epi flow ratio was depressed in the Aob , Aob $_{H S}$ and Shamc hearts, indicating that the left ventricular endocardium was seriously underperfused in these hearts. This effect was most pronounced in the Aobc hearts. At this time point the flow ratio was already normalized in Sham ${ }_{H S}$ hearts. The flow distribution assessed in the late reperfusion phase $(25 \mathrm{~min})$ was completely normalized in both groups of Sham hearts, whereas subendocardial underperfusion persisted in the Aob $\mathrm{C}$ hearts. In Aob $\mathrm{HS}$ hearts, however subendocardial perfusion was significantly improved, and almost equal in epicardial and endocardial regions. 


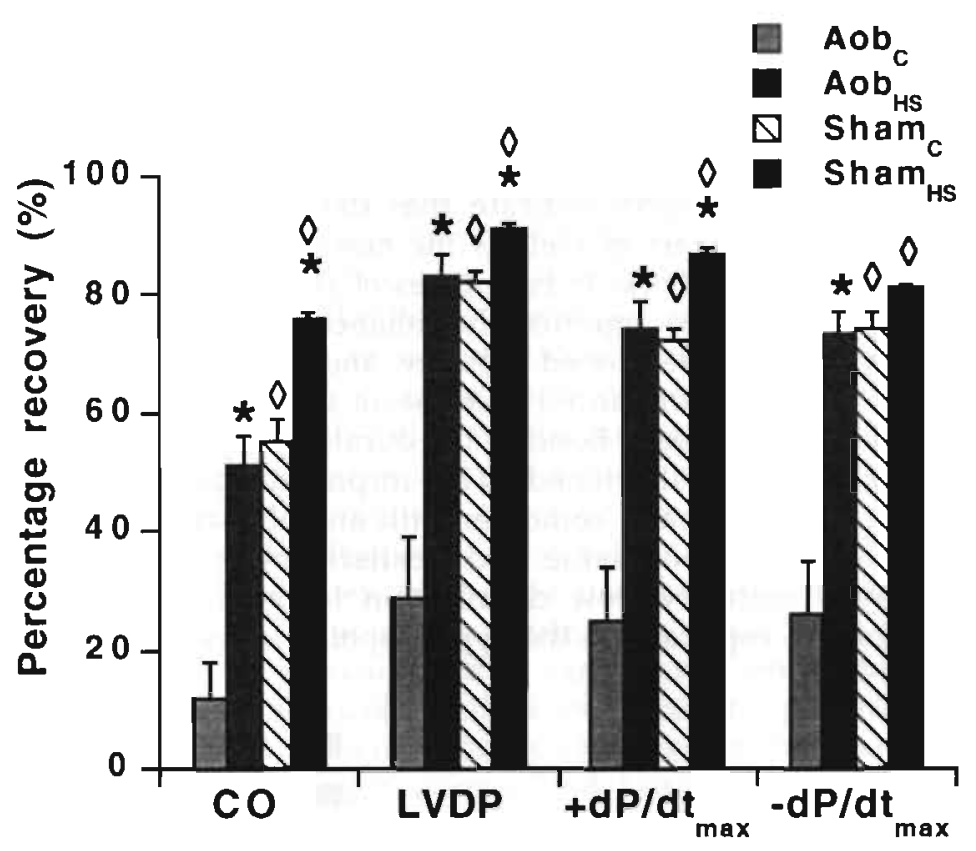

Figure 2: Postischemic percentage recovery of the hemodynamic variables in isolated hypertrophied (Aob) and non-hypertrophied (Sham) ejecting hearts of heat-shocked (HS) and control (C) rats. Data are presented as mean values \pm s.e. $\mathrm{CO}$ : cardiac output; LVDP: left ventricular developed pressure; $+/-\mathrm{dP} / \mathrm{dt}_{\text {max }}$ : respectively positive and negative maximal first derivative of the left ventricular pressure. * : significantly different from the values in the corresponding control group; ${ }^{0}$ : significantly different from the values in the corresponding Aob group.

Table 4: Total preischemic (30 min) and postischemic (45 min) loss of lactate dehydrogenase $(\mathrm{LDH})$ and creatine kinase (CK) from isolated hearts of anesthetized (C) and heat-shocked (HS) aorta-banded (Aob) and sham-operated (Sham) rats.

\begin{tabular}{|c|c|c|c|c|}
\hline & $\begin{array}{c}\text { Aobc } \\
(n=14)\end{array}$ & $\begin{array}{l}\text { AobHS } \\
(n=14)\end{array}$ & $\begin{array}{l}\text { Shamc } \\
(n=12)\end{array}$ & $\begin{array}{c}\text { ShamHS } \\
(n=12)\end{array}$ \\
\hline \multicolumn{5}{|l|}{$\mathrm{LDH}\left(\mathrm{U} \cdot \mathrm{g}^{-1} w w\right)$} \\
\hline pre & $4.0 \pm 0.5$ & $5.4 \pm 1.0$ & $2.9 \pm 0.2$ & $3.5 \pm 0.4$ \\
\hline post & $16.6 \pm 1.9$ & $18.7 \pm 1.9$ & $14.8 \pm 2.0$ & $14.7 \pm 1.1$ \\
\hline \multicolumn{5}{|l|}{ CK $\left(U \cdot g^{-1} w w\right)$} \\
\hline pre & $4.6 \pm 0.6$ & $6.1 \pm 1.1$ & $3.3 \pm 0.3$ & $3.3 \pm 0.2$ \\
\hline post & $21.1 \pm 2.4$ & $24.3 \pm 3.0$ & $22.9 \pm 3.0$ & $20.3 \pm 1.6$ \\
\hline
\end{tabular}

The data are presented as mean values \pm s.e. U. $g^{-1}$ ww: units per gram wet heart tissue weight.

\section{Myocardial catalase content}

Table 5 indicates that the native tissue catalase activity was not significantly different between the two groups of hypertrophied hearts (8.9 vs 10.1 U.mg-1 
protein). However, in the ShamHS significantly higher values were found than in the Sham ${ }_{C}$ hearts (8.6 vs 13.3 U.mg-1 protein, $\mathrm{p}<0.05$ ).

\section{DISCUSSION}

The findings in the present study indicate that the ischemia tolerance of the compensated hypertrophied heart as well as the non-hypertrophied heart can be improved by whole body heat-shock. In both types of hearts, appreciable protection is obtained, as evidenced by the significantly enhanced postischemic recovery of cardiac output, left ventricular developed pressure, and left ventricular contractility and relaxation, and the less pronounced increase of left ventricular end-diastolic pressure in the hypertrophied heart. Besides, the duration of postischemic electrical disturbances is significantly shortened. The improved postischemic cardiac recovery in the heat-shocked hearts coincides with an enhanced coronary flow as observed during both the preischemic and postischemic periods, and with a significantly improved coronary flow distribution towards the subendocardial layers of the left ventricle, especially in the hypertrophied heart.

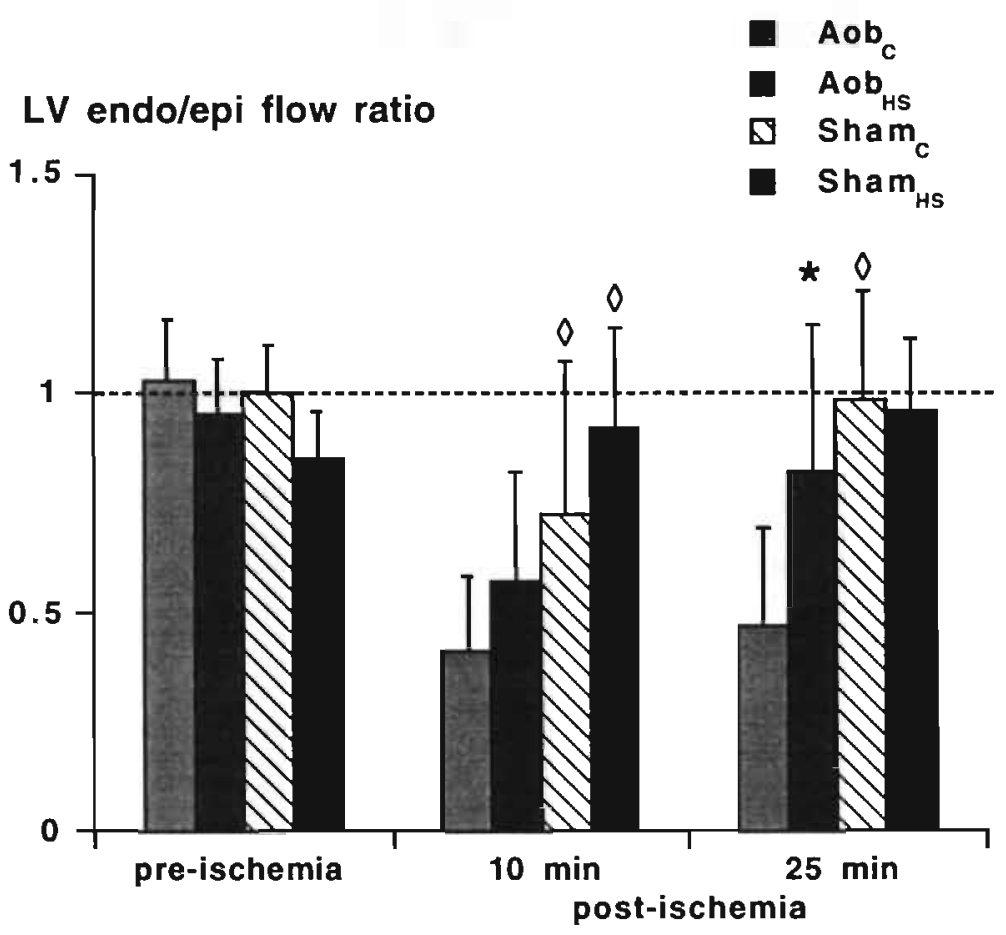

Figure 3: Distribution of coronary flow over the left ventricular endocardial and epicardial layers in hypertrophied (Aob) and non-hypertrophied (Sham) hearts of heat-shocked (HS) and control (C) rats. Data are presented as mean values \pm s.e. : significantly different from the values in the corresponding control group; : significantly different from the values in the corresponding Aob group. 


\section{The role of coronary flow}

In a preliminary study from our laboratory total body hyperthermia 24 hours prior to the ischemic insult was found to significantly increase coronary flow in both hypertrophied and non-hypertrophied hearts [7]. This observation raised the question as to whether elevated coronary flow and increased resistance to ischemia and reperfusion damage are causally related. The present findings clearly show that in the hypertrophied heart the deleterious effects of perfusion at $8 \mathrm{kPa}$ are abolished to a large extent by heat pretreatment, and that improved postischemic functional outcome is associated with elevated coronary flow and a more homogeneous distribution of flow during the postischemic period. It is acknowledged, however, that this study does not offer exclusive evidence for a determinant role of enhanced or better distributed coronary flow for the improved postischemic function of heatshocked hearts. More detailed studies will be needed to address this question.

To our best knowledge, it has not been reported before that hyperthermic pretreatment has such a prominent effect on coronary flow. In the experiments performed by Currie and colleagues [8] and Yellon and co-workers [31], hearts were perfused at constant flow-rates, suggesting that there was no relation between the level of total coronary flow and hyperthermic protection. However, in their experiments it cannot be excluded that vasodilation and, hence, improved flow distribution occurred, because no data on coronary perfusion pressure were provided. The question of total coronary flow and its myocardial distribution is particularly relevant for the hypertrophied heart because earlier studies have shown that a to low perfusion pressure is known to induce serious postischemic subendocardial underperfusion, associated with persistent electrical disturbances [26]. In the hypertrophied heart, enhancing coronary flow by increasing perfusion pressure results in a significant improvement of postischemic functional recovery $[20,26]$, but also enhances the oxygen demand of the heart due to the concomitant increase in afterload.

The mechanism underlying the heat-shock associated vasodilation is unknown. Coronary flow can be increased by a variety of mechanisms including altered function of the coronary endothelium and/or coronary smooth muscle cells $[11,14]$. Although the vascular endothelium is known to have the ability to express HSP72 [12; unpublished observations], an interaction of this protein with vasodilating mechanisms has not been reported.

\section{The potential role of oxygen radical scavengers}

The protection of heat-shock pretreatment against ischemia and reperfusion damage has been associated with an increased ability of cardiac cells to scavenge toxic free oxygen radicals, which are known to exert reperfusion damage [17]. Yellon and colleagues [31] reported that the improved postischemic functional recovery of normal hearts after heat-shock is associated with a significant increase in reduced tissue glutathione and a significant decrease in oxidized tissue glutathione, reducing oxidative stress. Currie and coworkers [8] found that improved function of the postischemic non-hypertrophied myocardium was closely associated with an increased activity of catalase, the hydroxyl radical scavenger. Similar results were obtained by Brown and colleagues [5], who described a correlation between higher endogenous catalase activity and improved postischemic cardiac function in hearts pretreated with endotoxines. Endotoxins may induce a heat-shock reponse indirectly by the stimulated release of cytokines [16]. Enhanced catalase activity is believed to be essential, since pretreatment with 3'-aminotriazol, a catalase blocking agent, abolishes the protection offered by hyperthermic pretreatment [13]. However, 
the specificity of 3 -aminotriazol in blocking catalase, is debatable. Moreover, in the present investigation the endogenous catalase activity was found to be significantly increased only in non-hypertrophied hearts. Therefore, the significant hemodynamic improvement in the hypertrophied hearts cannot be explained by an enhanced capacity to scavenge hydroxyl radicals. Besides, like reported before by others [8], endogenous catalase activity was not significantly increased in hearts after ischemia and reperfusion (unpublished observations). Furthermore, recently Amrani and colleagues [2] did not find a positive correlation between catalase activity and the degree of postischemic mechanical recovery in the nonhypertrophied heart.

Table 5: Native endogenous catalase activity and total protein content in hearts of anesthetized (C) and heat-shocked (HS) aorta-banded (Aob) and sham-operated (Sham) rats.

\begin{tabular}{|c|c|c|c|c|}
\hline & $\begin{array}{l}\text { Aobc } \\
(n=5)\end{array}$ & $\begin{array}{c}\text { Aob HS } \\
(n=6)\end{array}$ & $\begin{array}{l}\text { Shamc } \\
(n=6)\end{array}$ & $\begin{array}{c}\text { Sham HS } \\
(n=5)\end{array}$ \\
\hline $\begin{array}{l}\text { catalase activity } \\
\left(U \cdot g^{-1} w w\right) \\
\text { protein content }\end{array}$ & $1543 \pm 22$ & $1697 \pm 51$ & $1469 \pm 40$ & $1942 \pm 32^{*}$ \\
\hline $\begin{array}{l}\left(\mathrm{mg} \cdot \mathrm{g}^{-1} \mathrm{ww}\right) \\
\text { catalase activity }\end{array}$ & $176 \pm 9$ & $176 \pm 19$ & $172 \pm 9$ & $150 \pm 13$ \\
\hline (U.mg ${ }^{-1}$ protein) & $8.9 \pm 0.5$ & $10.1 \pm 1.1$ & $8.6 \pm 0.8$ & $13.3 \pm 1.1^{*}$ \\
\hline
\end{tabular}

The data are presented as mean values \pm s.e. $U . g^{-1}$ ww: units per gram wet heart tissue weight. Native hearts were perfused in the retrograde way during 5 minutes to remove blood from the coronary arteries; ": significantly different from the values in the corresponding control group.

\section{Electrical stability and enzyme loss}

The significant reduction in the duration of postischemic arrhythmias in hypertrophied and non-hypertrophied heat-shocked hearts is in agreement with the observations of Steare [28]. In the present investigation, this phenomenon might be flow-related, rather than the consequence of reduced free radical formation, since catalase activity was not significantly increased in the heat-shocked hypertrophied heart.

The postischemic enzyme release fails to prove a heat-shock mediated stabilization of cellular membranes. This lack of protection could be explained by the observation that both groups of non-heat-shocked hearts do not release all enzymes from the damaged cells as a consequence of unadequate coronary perfusion or no-reflow [30].

From this study it may be concluded that an increased and more homogeneous perfusion of the myocardium, as found in both types of heat-shocked hearts, is likely to be the main basis for the heat-shock mediated protective effect. The mechanism(s) by which heat-shock reduces coronary vascular resistance remain(s) to be elucidated. Although in the non-hypertrophied heart protection against ischemia induced injury can be associated with changes in antioxidant status, this mechanism cannot explain the protective effect, observed in the hypertrophied heart. 


\section{LITERATURE}

1. Aebi H. Catalase in vitro. Meth. Enzymol. 105: 121-126, 1984

2. Amrani M., N.J. Allen, J. O'Shea, J. Corbett, M.J., Dunn, S. Tadjkarimi, S. Theodoropoulos, J. Pepper, and M.H. Yacoub. Role of catalase and heat-shock protein on recovery of cardiac endothelium and mechanical function after ischemia. Cardioscience 4: 193-198, 1993

3. Bergmeyer H.U., and E. Bernt. UV assay for creatine kinase. In: Methods of Enzymology, Weinheim Verlag Chemie GmbH, pp 784-788, vol. 2, 1974

4. Bergmeyer H.U., and E. Bernt. UV assay for lactate dehydrogenase with pyruvate and NADH. In: Methods of Enzymology, Weinheim Verlag Chemie GmbH, pp 574-579, vol. 2, 1974

5. Brown J.M., M.A. Grosso, L.S. Terada, G.J.R. Whitman, A. Banerje, C.W. White, A.H. Harke, and J.E. Repine. Endotoxin pretreatment increases endogenous myocardial catalase activity and decreases reperfusion injury of isolated rat hearts. Proc. Natl. Acad. Sci. USA 86: 2516-2520, 1989

6. Ciocca D.R., S. Oesterreich, G.C. Chamness, W.L. McGuire, and S.A. Fuqua. Biological and Clinical implications of heat-shock protein 27.000 (HSP27): a Review. J. Natl. Cancer Inst 85: 1558-1570, 1993

7. Cornelussen R., L.H.E.H. Snoeckx, L.G. de Bruin, G.J. van der Vusse, and R.S. Reneman. Hyperthermic preconditioning improves ischemia tolerance of the hypertrophied and nonhypertrophied rat heart. J. Mol. Cell. Cardiol. 25 (suppl. 1): S.56, 1993 (abstract)

8. Currie R.W., M. Karmazyn, M. Kloc, and K. Mailer. Heat-shock response is associated with enhanced postischemic recovery. Circ. Res. 63: 543-549, 1988

9. Currie R.W., R.M. Tanguay, and J.G. Kingma. Heat shock response and limitation of tissue necrosis during occlusion/reperfusion in rabbit hearts. Circulation 87: 963-971, 1993

10. Delcayre C., J.-L. Samuel, F. Marotte, M. Best-Belpomme, J.J. Mercadier, and L. Rappaport. Synthesis of stress proteins in rat cardiac myocytes $2-4$ days after imposition of hemodynamic overload. J. Clin. Invest. 82: 460-468, 1988

11. Domenech R., P. Macho, R. Gonzales, and J.P. Huidobro-Toro. Effect of endothelin on total and regional coronary resistance on myocardial contractility. Eur. I. Pharmacol. 192: 409-416, 1991

12. Jornot L., M.E. Mirault, and A.F. Junod. Differential expression of hsp70 stress proteins in human endothelium cells exposed to heat-shock and hydrogen peroxide. Am. J. Respir. Cell. Mol. Biol. 5: 265-275, 1991

13. Karmazyn M., K. Mailer, and R.W. Currie. Acquisition and decay of heat-shock-enhanced postischemic ventricular recovery. Am. J. Physiol. 259: H424-H431, 1990

14. Lamontagne D., U. Pohl, and R. Busse. Mechanical deformation of vessel wall and shear stress determine the basal release of endothelium derived relaxing factor in the intact rabbit coronary vascular bed. Circ. Res. 70: 123-130, 1992

15. Lowry O.H., N.J. Rosenbrough, A.L. Farr, and R.J. Randall. Protein measurement with the folin phenol reagent. J. Biol. Chem. 193: 265-275, 1951

16. Löw-Friedrich I, D. Weisensee, P. Mitrou, and W. Schoeppe. Cytokines induce stress protein formation in cultered cardiac myocytes. Basic Res Cardiol 87: 12-18, 1992

17. Manning A.S., and D.J. Hearse. Reperfusion-induced arrhythmias: mechanisms and prevention. J. Mol. Cell. Cardiol. 16: 497-518, 1984

18. Marber M.S., D.M. Walker, D.S. Latchman, and D.M. Yellon. Cardiac 72- and 60-kDa stress protein induction by repetitive ischemia and heat stress. J. Mol. Cell. Cardiol. 25 (suppl 1): S.55, 1993 (abstract)

19. Prinzen F.W., G.J. van der Vusse, and R.S. Reneman. Blood flow distribution in the left ventricular free wall open-chest dogs. Bas. Res. Cardiol. 76: 431-437, 1981

20. Rabinov M., M. Newman, J.J. Smolich, and F.L. Rosenfeldt. Adverse effects of low-presure reperfusion after hypothermic cardioplegia in normal and hypertrophic hearts. J. Thorac. Cardiovasc. Surg. 102: 695-706, 1991.

21. Sanders Williams R., and I.J. Benjamin. Stress proteins and cardiovascular disease. Mol. Biol. Med. 8: 197-206, 1991

22. Schlesinger M.J. Heat-shock proteins. J. Biol. Chem. 265: 12111-12114, 1990

23. Snoeckx L.H.E.H., F. Contard, J.-L. Samuel, F. Marotte, and L. Rappaport. The expression and cellular distribution of heat-shock and nuclear oncogene proteins in rat hearts. Am. J. Physiol. 263: H1443-H1451, 1991 


\section{Chapter 2}

24. Snoeckx L.H.E.H., J.J. Schrijen, M. van Bilsen, W.J. Lammers, T. van der Nagel, G.J. van der Vusse, and R.S. Reneman. A microcomputer system for hemodynamic measurements in isolated, working rat hearts. Comp. Biol. Med. 4: 301-309, 1986

25. Snoeckx L.H.E.H., G.J. van der Vusse, W.A. Coumans, and R.S. Reneman. The effects of global ischemia and reperfusion on compensated hypertrophied hearts of aortabanded rats. I. Mol. Cell. Cardiol. 22: 1439-1451, 1990

26. Snoeckx L.H.E.H., G.J. van der Vusse, W.A. Coumans, P.H.M. Willemsen, and R.S. Reneman Differences in ischemia tolerance between hypertrophied hearts of adult and aged spontaneously hypertensive rats. Cardiovasc. Res. 27: 874-881, 1993

27. Snoeckx L.H.E.H., G.J. van der Vusse, W.A. Coumans, and R.S. Reneman. Recovery of hypertrophied rat hearts after global ischemia and reperfusion at different perfusion pressures. pfligers Arch. (Eur. J. Physiol.) 413: 303-312, 1989

28. Steare S, and D.M. Yellon. The protective effect of heat stress against reperfusion arrhythmias in the rat. J. Mol. Cell. Cardiol. 25: 1471-1481, 1993

29. van Bilsen M., L.H.E.H. Snoeckx, T. Arts, G.J. van de Vusse, and R.S. Reneman. Performance of the isolated, ejecting heart: Effects of aortic impedance and exogenous substrates. Pflïgers Arch. (Eur. J. Physiol.) 419: 7-12, 1991

30. van der Laarse A., P. van Dijkman, J. Altona, A. Zoet, and P. Oemrawsingh. Coronary flow-rate dependent enzyme release rate from normoxic and anoxic rat hearts in vitro. Cardiovasc. Res. 18: 438-442, 1984

31. Yellon D.M., E. Pasini, A. Cargnoni, M.S. Marber, D.S. Latchman, and R. Ferrari. The protective role of heat stress in the ischemic and reperfused rabbit myocardium. J. Mol. Cell. Cardiol. 24: $895-907,1992$ 


\section{Chapter 3}

\section{IMPROVEMENT OF POSTISCHEMIC CARDIAC FUNCTION IN THE HEAT-SHOCKED HYPERTROPHIED AND NON-HYPERTROPHIED HEART IS PERFUSION PRESSURE DEPENDENT}

This study was published in part as "Is the postischemic heat shock-mediated cardioprotection of the hypertrophied rat heart perfusion pressure dependent ?"

by R. Cornelussen, G.J. van der Vusse and L.H.E.H. Snoeckx

in the Proceedings of the International Society for Heart Research, XV European Section meeting, pp. 559-564, 1994. 


\section{INTRODUCTION}

As shown in Chapter 2, hyperthermic treatment leads to a significant improvement of postischemic functional recovery of both hypertrophied and non-hypertrophied in vitro-perfused rat hearts investigated 24 hours after pretreatment [3]. The afterluad against which the hearts had to eject in these experiments was relatively low, i.e., $8.0 \mathrm{kPa}$. In the non-pretreated heart, and especially in the hypertrophied heart, it was found that the subendocardial layers of the left ventricle were significantly underperfused during the initial reperfusion phase. Because the hypertrophied heart is known to be extremely vulnerable to postischemic subendocardial underperfusion $[3,7]$, it is important to state that the deleterious effects of this underperfusion are most likely prevented by hyperthermic pretreatment, as indicated by a more homogeneous postischemic flow distribution throughout the left ventricular wall, the reduction in the duration of postischemic electrical instability, and the significant improvement of the postischemic left ventricular contractile function [3].

Earlier it was shown that postischemic subendocardial underperfusion of the non-pretreated hypertrophied heart can also be improved by reperfusing the myocardium at elevated coronary perfusion pressures, like $13.3 \mathrm{kPa}$ [7]. Although under such circumstances the load imposed upon the hypertrophied left ventricle is increased, the attained postischemic cardiac output levels are higher and comparable to those in the non-hypertrophied heart perfused at a relatively low afterload of $8.0 \mathrm{kPa}$. Since it is not known whether hyperthermic pretreatment can further ameliorate the functional recovery of the hypertrophied heart perfused at elevated coronary perfusion levels, the postischemic functional recovery of hypertrophied as well as non-hypertrophied hearts was studied at elevated coronary perfusion pressure levels, i.e., $13.3 \mathrm{kPa}$, twenty-four hours after hyperthermic pretreatment.

\section{MATERIALS AND METHODS}

\section{Animal preparation}

The experiments were performed on 13 weeks old male Lewis rats $(n=32)$. Eight weeks earlier the animals had been either aorta-banded (Aob) or sham-operated (Sham) as described earlier [5]. For hyperthermic treatment, the animals were anesthetized with Hypnorm ${ }^{\circledR}(0.01 \mathrm{mg} / 100 \mathrm{~g}$ body weight fentanyl plus $0.5 \mathrm{mg} / 100 \mathrm{~g}$ body weight fluanisone s.c.) and placed on a temperature-controlled heating pad until their rectal temperature reached $42^{\circ} \mathrm{C}$ (AobHS: $n=7$; ShamHS: $n=8$ ). This temperature was maintained for $15 \mathrm{~min}$. Non-heat-shocked anesthetized animals followed the same protocol except for the heating ( $A_{0}$ : $n=9$; ShamC: $n=8$ ). After treatment the animals were allowed to recover for 24 hours at normal ambient temperature.

\section{Heart preparation}

Twenty-four hours after hyperthermic pretreatment or anesthesia the animals were reanesthetized. After cervical dislocation the hearts were rapidly removed from the thorax and immediately immersed in an ice-cold Tyrode buffer solution, containing (in mmol/l): $\mathrm{NaCl}(130.0), \mathrm{KCl}(5.6), \mathrm{CaCl}_{2}$ (2.2), $\mathrm{MgCl}_{2}$ (1.0), $\mathrm{NaH}_{2} \mathrm{PO}_{4}$ (1.2), $\mathrm{NaHCO}_{3}$ (28.6) and $\mathrm{D}(+)$ glucose (11.1). The hearts were weighed and connected via the aorta and pulmonary venes to a perfusion apparatus. Hearts were allowed to eject 
antegradely under a left atrial filling pressure of $1.3 \mathrm{kPa}$ and against a diastolic aortic pressure $\left(\mathrm{P}_{\mathrm{ao}, \text { diast }}\right)$ of $13.3 \mathrm{kPa}$. The perfusion buffer was continuously gassed with carbogen $\left(95 \% \mathrm{O}_{2} ; 5 \% \mathrm{CO}_{2} ; \mathrm{pO}_{2}>70 \mathrm{kPa} ; \mathrm{pH}=7.32-7.45 ; 37^{\circ} \mathrm{C}\right)$. Aortic pressure was measured one $\mathrm{cm}$ above the aortic valve and left ventricular pressure through the apex of the heart with a small polyethylene catheter connected to an external pressure transducer (Century Technology Company; Inglewood, USA). Left ventricular developed pressure (LVDP) was calculated as the difference between systolic and end-diastolic pressure. Left ventricular performance and relaxation were respectively estimated from the maximal positive and negative first derivative of left ventricular pressure $\left(+\mathrm{dP} / \mathrm{dt}_{\max }\right.$ and $\left.-\mathrm{dP} / \mathrm{dt}_{\max }\right)$. The flow in the aortic cannula was measured with an extracorporeal flowprobe (diameter $3 \mathrm{~mm}$ ) connected to an electromagnetic flowmeter (Skalar 601). Coronary flow (CF) was measured by timed collection of the coronary perfusate dripping from the heart. Cardiac output (CO) was defined as the sum of aortic flow and coronary flow, and, by definition, was zero when the hearts were perfused in the retrograde way. The hearts were paced at $5 \mathrm{~Hz}$ throughout the experiments, except during ischemia and the first $10 \mathrm{~min}$ of reperfusion.

At the end of a preischemic period of $40 \mathrm{~min}$ the hearts were subjected to 45 min of global ischemia. During this ischemic period myocardial temperature dropped to $32^{\circ} \mathrm{C}$. Thereafter the hearts were reperfused for $15 \mathrm{~min}$ in the retrograde way and for $30 \mathrm{~min}$ in the antegrade way at a $P_{a o, d i a s t}$ identical to that used during the preischemic period. The maximal steady state values of the various hemodynamic variables attained during the antegrade preischemic and postischemic perfusion periods were used for the calculation of the percentage functional recovery of the hearts. Coronary effluent samples, which were collected at $5 \mathrm{~min}$ time intervals were assessed later for the loss of the cytosolic marker enzymes creatine kinase (CK) and lactate dehydrogenase (LDH) [1, 2].

\section{Statistical analysis}

Data are presented as meantsd. Differences between heat-shocked and anesthetized and between non-hypertrophied and hypertrophied groups of hearts were evaluated for statistical significance ( $\mathrm{p} \leq 0.05$ ) using the Mann-Whitney $U$-test.

\section{RESULTS}

\section{Degree of hypertrophy}

As presented in Table 1, the heart weight and heart weight to body weight ratios were significantly higher in both Aob groups than in both Sham groups, as aortabanding resulted in a degree of cardiac hypertrophy of about $30 \%$.

\section{Hemodynamics}

Preischemic period: As shown in Figure 1, throughout the preischemic period coronary flow was significantly higher in each group of heat-shocked hearts than in the corresponding control hearts, confirming the results obtained in both hypertrophied and non-hypertrophied hearts perfused at a perfusion pressure of 8.0 $\mathrm{kPa}$ [3]. During the antegrade perfusion period, coronary flow was also significantly higher in both groups of non-hypertrophied hearts compared to the corresponding groups of hypertrophied hearts (Table 2). As far as the other hemodynamic variables are concerned, no other preischemic differences could be found, except for the 
significantly higher maximal rate of relaxation of the left ventricle $\left(-\mathrm{dP} / \mathrm{dt}_{\max }\right)$ in the ShamHS than the AobHS hearts (Table 2).

Table 1: Heart weight (HW), body weight (BW) and heart weight to body weight ratio (HW/BW) in anesthetized (C) and heat-shocked (HS) aorta-banded (Aob) and shamoperated (Sham) rats.

\begin{tabular}{|c|c|c|c|}
\hline & $\begin{array}{l}\text { Heart weight } \\
\text { (g) }\end{array}$ & $\begin{array}{l}\text { Body weight } \\
\text { (g) }\end{array}$ & $\begin{array}{c}\mathrm{HW} / \mathrm{BW} \\
\left(10^{-2}\right)\end{array}$ \\
\hline $\operatorname{Aobc}(n=7)$ & $1.58 \pm 0.25^{\circ}$ & $286 \pm 22$ & $0.556 \pm 0.085^{\circ}$ \\
\hline AobHS $(n=9)$ & $1.60 \pm 0.190$ & $302 \pm 27$ & $0.522 \pm 0.057^{\circ}$ \\
\hline Shamc $(n=8)$ & $1.28 \pm 0.09$ & $306 \pm 22$ & $0.419 \pm 0.028$ \\
\hline ShamHS $(n=8)$ & $1.25 \pm 0.14$ & $305 \pm 27$ & $0.412 \pm 0.028$ \\
\hline
\end{tabular}

Table 2: Preischemic hemodynamic variables in hearts of anesthetized $(C)$ and heatshocked (HS) Aob and Sham rats.

\begin{tabular}{|c|c|c|c|c|}
\hline & $\begin{array}{l}\text { Aobc } \\
(n=7)\end{array}$ & $\begin{array}{c}\text { AobHS } \\
(n=9)\end{array}$ & $\begin{array}{c}\text { Shamc } \\
(n=8)\end{array}$ & $\begin{array}{c}\text { ShamHS } \\
(n=8)\end{array}$ \\
\hline $\begin{array}{l}\mathrm{CF}(\mathrm{ml} / \min . g) \\
C O(\mathrm{ml} / \mathrm{min}) \\
\mathrm{LVDP}(\mathrm{kPa}) \\
+\mathrm{dP} / \mathrm{dt}_{\max }(\mathrm{kPa} / \mathrm{s}) \\
-\mathrm{dP} / \mathrm{dt}_{\max }(\mathrm{kPa} / \mathrm{s})\end{array}$ & $\begin{array}{c}12.7 \pm 2.1^{\circ} \\
67 \pm 13 \\
15 \pm 0.3 \\
742 \pm 37 \\
510 \pm 66\end{array}$ & $\begin{array}{c}14.7 \pm 1.7^{*} 0 \\
72 \pm 8 \\
15 \pm 1.2 \\
723 \pm 192 \\
500 \pm 105^{\circ}\end{array}$ & $\begin{array}{c}14.7 \pm 1.4 \\
64 \pm 8 \\
15 \pm 0.8 \\
717 \pm 84 \\
557 \pm 56\end{array}$ & $\begin{array}{c}16.8 \pm 1.4^{*} \\
65 \pm 14 \\
15 \pm 0.8 \\
750 \pm 67 \\
637 \pm 68\end{array}$ \\
\hline
\end{tabular}

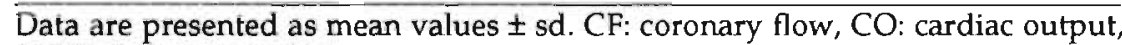
LVDP: left ventricular developed pressure, $+/-\mathrm{dP} / \mathrm{dt}_{\text {max }}$ : positive, respectively negative maximal first derivative of the left ventricular pressure. ${ }^{*}$ : significantly different from the values in the corresponding control group; 0 : significantly different from the values in the corresponding Sham group.

Postischemic period: During the first $15 \mathrm{~min}$ of reperfusion, in all hearts of the various groups a prominent reactive hyperemia occurred (Figure 1). Calculation of the differences between the coronary flow values during this period and representative preischemic values (taken at $\mathrm{t}=10 \mathrm{~min}$ ), the net excess flow was $40 \%$ in Shamc, $54 \%$ in Sham SS $_{3}, 36 \%$ in AobC and $45 \%$ in AobHS hearts. Later the CF values stabilized at about $80 \%$ of the preischemic values in all groups. Although throughout the postischemic period coronary flow was higher in both groups of heat-shocked hearts than in the corresponding control hearts, the differences at each time point were not statistically different.

ShamHS hearts showed a better postischemic recovery of the LVDP and $-\mathrm{dP} / \mathrm{dt}_{\max }$ variables than the corresponding control hearts (Table 3 ). Although the cardiac output levels in Sham $\mathrm{HS}_{\mathrm{S}}$ hearts were higher than in Shamc hearts, the 
level of significance was not reached $(p=0.08)$. Expressed as percentage, the recovery of $\mathrm{CO}$ in ShamHS hearts was significantly better in the Shamc hearts (Figure 2).
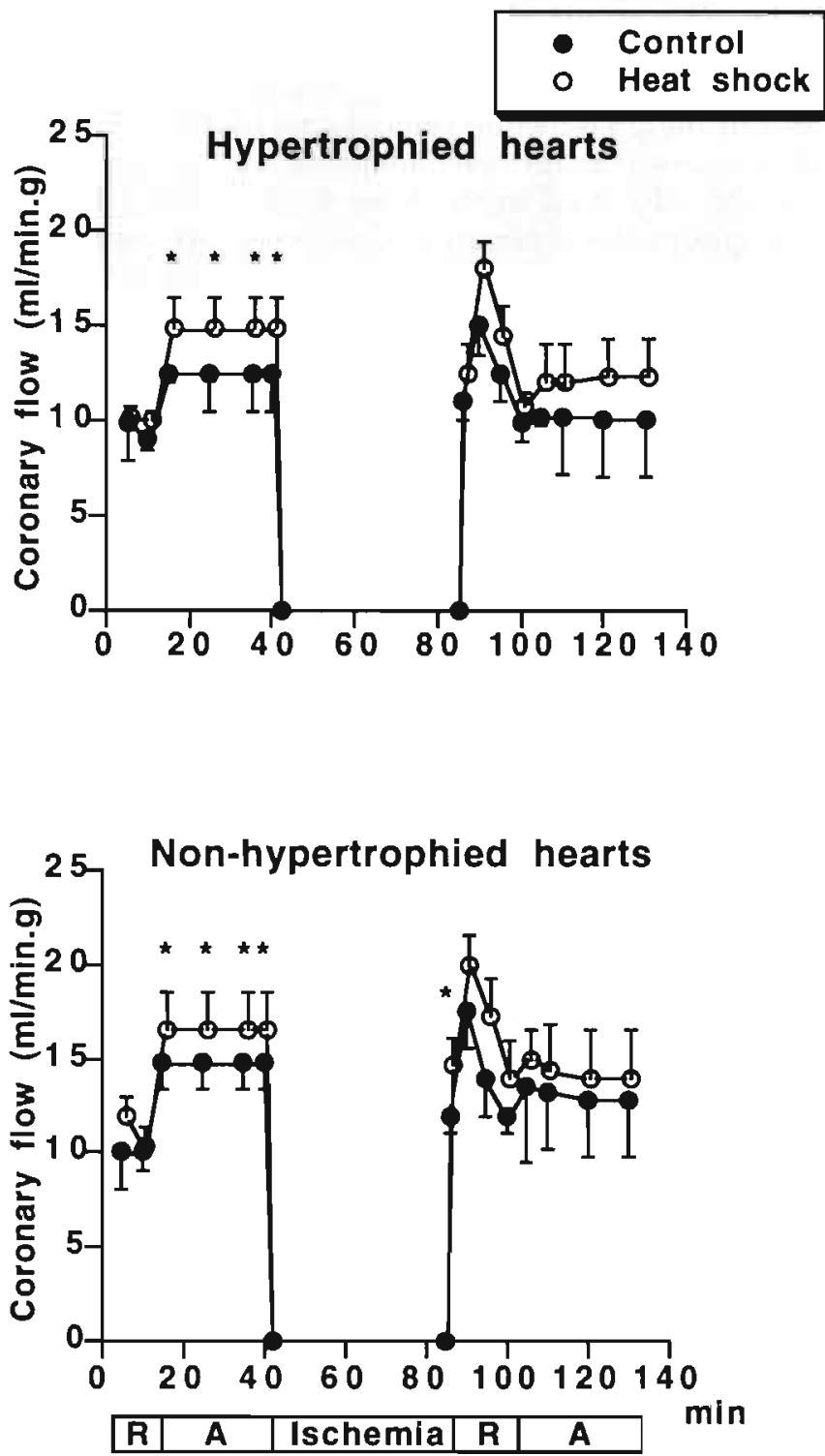

Figure 1: Weight related coronary flow before and after $45 \mathrm{~min}$ of global ischemia in hypertrophied (upper panel) and non-hypertrophied (lower panel) heatshocked and control rat hearts. Data are presented as mean values $\pm s d$. $R$, retrograde perfusion; $A$, antegrade perfusion. " : significantly different from the values in the corresponding control group. 
In the hypertrophied hearts heat pretreatment did not result in better recovery of left ventricular function, since no statistical differences were found with the control group. This was not due to a poor effect of heat shock, because the percentage recovery of cardiac output in AobHS hearts was even higher than the corresponding ShamHs hearts, i.e., $74 \%$ versus $64 \%$ (see Figure 2). The lack of statistical significant differences with the control group was also caused by a prominent functional recovery in the latter hearts. For instance, the recovery of $\mathrm{CO}$ in Aob $\mathrm{C}$ hearts amounted to $58 \%$ of the preischemic values compared to $38 \%$ in Shamc (Figure 2). This prominent recovery was further underlined by the significant better recovery of the LVDP and the $-\mathrm{dP} / \mathrm{dt}_{\max }$ in the Aob $\mathrm{C}$ than in Shamc hearts. In both control and heat-shocked groups the occurrence of arrhythmias was restricted to the first 8 min of reperfusion.

Table 3: Postischemic hemodynamic variables in hearts of anesthetized (C) and heatshocked (HS) Aob and Sham rats.

\begin{tabular}{lcccc}
\hline & $\begin{array}{c}\text { AobC } \\
(\mathrm{n}=7)\end{array}$ & $\begin{array}{c}\text { AobHS } \\
(\mathrm{n}=9)\end{array}$ & $\begin{array}{c}\text { Sham } \\
(\mathrm{n}=8)\end{array}$ & $\begin{array}{c}\text { Sham } \\
(\mathrm{n}=8)\end{array}$ \\
& $-10.5 \pm 3.2$ & $12.5 \pm 2.2$ & $12.6 \pm 2.7$ & $13.8 \pm 1.8$ \\
$\mathrm{CF}(\mathrm{ml} / \min \mathrm{g})$ & $10.5 \pm 14$ & $54 \pm 15$ & $25 \pm 18$ & $42 \pm 13^{*}$ \\
$\mathrm{CO}(\mathrm{ml} / \min )$ & $14 \pm 1.3$ & $14 \pm 0.9$ & $13 \pm 0.9$ & $14 \pm 0.7^{*}$ \\
$\mathrm{LVDP}(\mathrm{kPa})$ & $605 \pm 61$ & $595 \pm 124$ & $512 \pm 90$ & $603 \pm 107$ \\
$+\mathrm{dP} / \mathrm{dt}_{\max }(\mathrm{kPa} / \mathrm{s})$ & $412 \pm 87$ & $427 \pm 84$ & $358 \pm 103$ & $469 \pm 93^{*}$
\end{tabular}

Data are presented as mean values $\pm \mathrm{sd}$. CF: coronary flow, $\mathrm{CO}$ : cardiac output, LVDP: left ventricular developed pressure, $+/-\mathrm{dP} / \mathrm{dt}_{\max }$ : positive, respectively negative maximal first derivative of left ventricular pressure. *: significantly different from the values in the corresponding control group.

Table 4: Total preischemic $(30 \mathrm{~min})$ and postischemic $(45 \mathrm{~min})$ loss of lactate dehydrogenase ( $L D H)$ and creatine kinase (CK) from isolated hearts of anesthetized (C) and heat-shocked (HS) Aob and Sham rats.

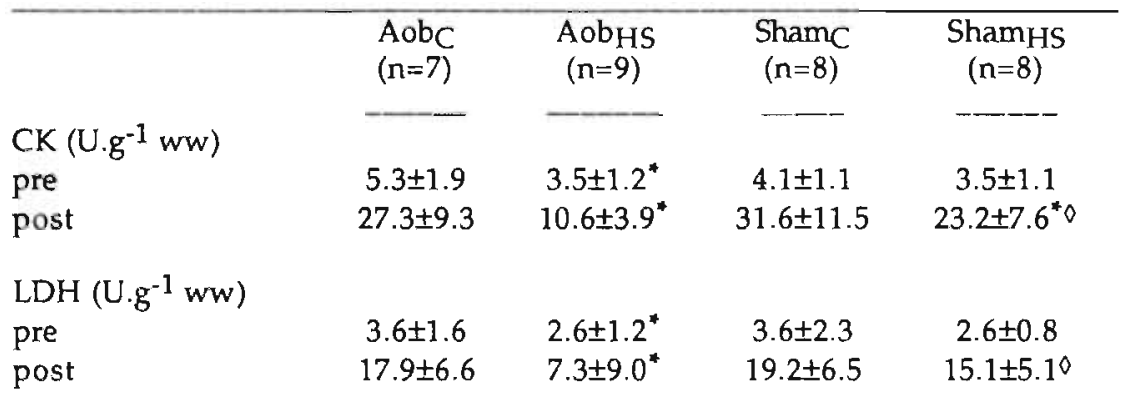

Data are presented as mean values $\pm \mathrm{sd}$. U.g-1 ww: units per gram wet heart tissue weight. ": significantly different from the values in the corresponding

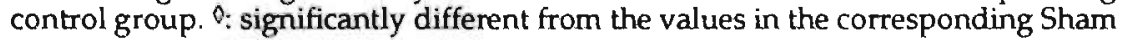
group. 


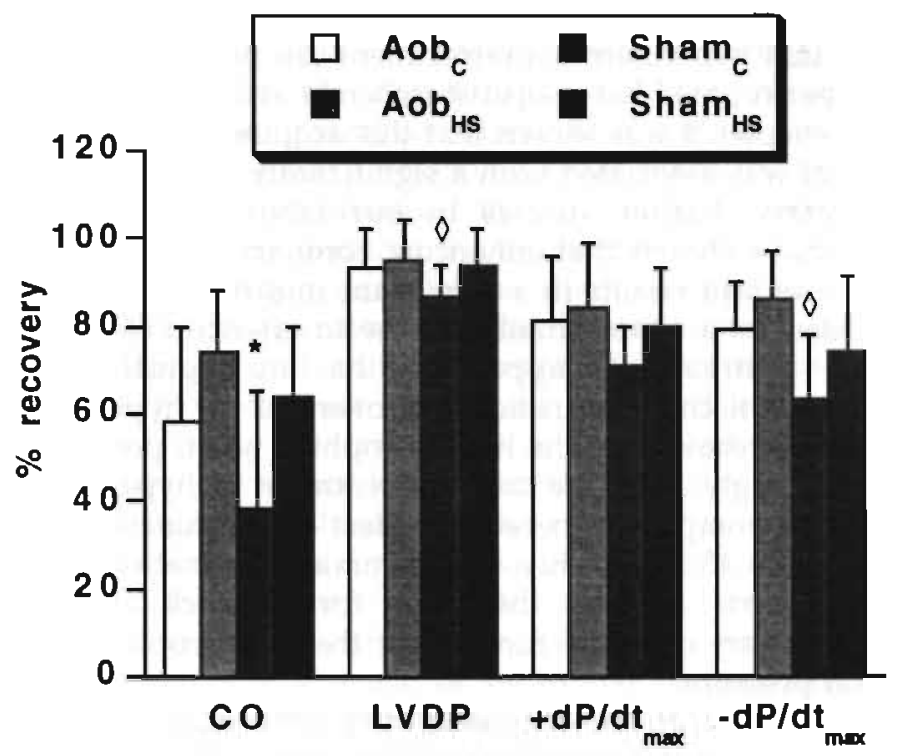

Figure 2: Postischemic percentage recovery of the hemodynamic variables in isolated hypertrophied (Aob) and non-hypertrophied (Sham) ejecting hearts of heat-shocked (HS) and control (C) rats. Data are presented as mean values $\pm s d$. $\mathrm{CO}$ : cardiac output; LVDP: left ventricular developed pressure; $+/-\mathrm{dP} / \mathrm{dt}_{\text {max }}$ : respectively positive and negative maximal first derivative of the left ventricular pressure. ": significantly different from the values in the corresponding control group; $\bullet$ : significantly different from the values in the corresponding Aob group.

\section{Biochemical analysis}

During the preischemic phase slightly lower LDH and CK amounts were lost by both groups of heat-shocked hearts compared to the corresponding control hearts (Table 4). In the groups of Aob hearts this difference was statistically significant. Throughout the reperfusion period both AobHS and ShamHS hearts lost significantly lower amounts of CK than the corresponding control hearts. The LDH loss was only significantly reduced in Aob HS hearts. When Aob and Sham hearts were compared, Aob $\mathrm{HS}_{\mathrm{S}}$ hearts lost significantly lower amounts of both enzymes than the Sham HS hearts.

\section{DISCUSSION}

The principal finding of this study was that the ischemia tolerance of the compensated adult hypertrophied heart perfused at a relatively high coronary perfusion pressure of $13.3 \mathrm{kPa}$ was not enhanced by hyperthermic pretreatment as far as the recovery of the hemodynamic variables is concerned. Otherwise, in the non-hypertrophied heart, hyperthermic pretreatment resulted in a significant improvement of postischemic recovery of only the left ventricular pressure and relaxation. In both the hypertrophied and non-hypertrophied heart, the 
postischemic creatine kinase loss into the coronary effluent was significantly lower in the heat-shocked than in the control hearts.

It is well known that hyperthermic pretreatment can protect the hypertrophied as well as the non-hypertrophied heart against ischemia and reperfusion damage [3, 4,8 ]. In the previous chapter it was shown that this acquired ischemia tolerance by hyperthermic treatment was associated with a significantly increased coronary flow in both types of hearts. Earlier studies in our laboratory on compensated hypertrophied hearts have shown that enhancing coronary flow by increasing the aortic perfusion pressure also results in a significant improvement of postischemic functional recovery, despite a concomitant increase in afterload [6]. In the present study, hyperthermic pretreatment apparently has no significant additional beneficial effect on the postischemic functional recovery of the hypertrophied heart. In Table 5 the percentage recovery of the hyperthrophied heart, perfused at 8.0 and $13.3 \mathrm{kPa}$ is shown. Strikingly, hyperthermic pretreatment in hypertrophied hearts perfused at $8.0 \mathrm{kPa}$ has a comparable beneficial effect on the functional recovery as increasing the afterload to $13.3 \mathrm{kPa}$ only. This prominent beneficial effect of high afterload on control hearts may be the cause for the lack of an additional improvement of the recovery of pump function of the hypertrophied heat-shocked heart at this perfusion pressure.

These observations could lead to the conclusion that both high perfusion pressure and heat shock have a common denominator for their protective effect on the hypertrophied heart. This denominator could then be the enhanced and/or more homogeneous coronary flow distribution after cessation of ischemia, a phenomenon observed in heat-shocked hearts perfused at $8.0 \mathrm{kPa}$ [3] and in nonheated hearts during reperfusion at high afterload [7]. Otherwise, it can not be excluded that, because of an adverse effect of heat shock on the pump performance of the heart at high loading conditions, the beneficial effects of heat shock are not as prominent at high perfusion pressure levels. At present it is unknown whether the Frank-Starling mechanism remains unaffected in the hyperthermically pretreated heart. Testing the left ventricular performance at varying preloads and afterloads could therefore be helpful in the evaluation of the effects of heat shock on the intrinsic mechanical myocardial properties.

Table 5: Percentage recovery of hemodynamic variables in hearts of anesthetized $(\mathrm{C})$ and heat-shocked (HS) Aob rats, perfused at $8.0 \mathrm{kPa} \#$ and $13.3 \mathrm{kPa}$.

\begin{tabular}{|c|c|c|c|c|}
\hline & \multicolumn{2}{|c|}{$\mathrm{P}_{\text {ao,diast }}=8.0 \mathrm{kPa}$} & \multicolumn{2}{|c|}{$\mathrm{P}_{\mathrm{ao}, \text { diast }}=13.3 \mathrm{kPa}$} \\
\hline & $\begin{array}{c}\text { Aobc } \\
(n=15)\end{array}$ & $\begin{array}{l}\text { AobHS } \\
(n=14)\end{array}$ & $\begin{array}{l}\text { Aobc } \\
(\mathrm{n}=7)\end{array}$ & $\begin{array}{c}\text { AobHS } \\
(n=9)\end{array}$ \\
\hline $\mathrm{CO}$ & $12 \pm 24$ & $51 \pm 17^{*}$ & $58 \pm 22^{*}$ & $74 \pm 14^{*}$ \\
\hline LVDP & $29 \pm 40$ & $83 \pm 15^{*}$ & $93 \pm 9^{*}$ & $95 \pm 9^{*}$ \\
\hline$+\mathrm{dP} / \mathrm{dt}_{\max }$ & $25 \pm 36$ & $74 \pm 17^{*}$ & $81 \pm 9^{*}$ & $84 \pm 15^{*}$ \\
\hline$-\mathrm{dP} / \mathrm{dt}_{\max }$ & $26 \pm 36$ & $73 \pm 14^{*}$ & $79 \pm 11^{*}$ & $86 \pm 11^{*}$ \\
\hline
\end{tabular}


The loading conditions, i.e., $13.3 \mathrm{kPa}$, were more unfavourable for the nonhypertrophied than for the hypertrophied heart. Nevertheless heat shock pretreatment seemed to positively affect to a certain extent the postischemic pumping ability in the non-hypertrophied heart. Since the beneficial effects of heat shock are less clear at this afterload than at the lower afterload at $8.0 \mathrm{kPa}$ (see Chapter 2), it can be concluded that the mechanism behind the heat shock-mediated cardioprotection is not independent of the afterload imposed upon the heart.

Although the improvement of the hemodynamic outcome of the heatshocked hypertrophied and non-hypertrophied heart is absent or less outspoken when the hearts have to eject against an increased afterload, protection at the cellular level is clearly present. This is evidenced by the significant lower postischemic release of creatine kinase into the coronary effluent. It is reasonable to assume that in hearts perfused at elevated perfusion pressure postischemic underperfusion is absent as a consequence of the combined effects of high afterload and heat shock on the coronary flow distribution and that, as such, all lost enzymes will be released into the coronary effluent [7]. The contradiction between the lesser loss of enzymes and the absence of improved hemodynamic function in heatshocked hearts remains to be elucidated.

In conclusion, hyperthermic pretreatment does not improve postischemic hemodynamic recovery in the hypertrophied heart when reperfused at a high perfusion pressure. In addition, hyperthermic pretreatment is less effective in protecting the postischemic non-hypertrophied heart at high afterload level compared to the protection observed at low afterload level. The heat-shocked heart perfused at high perfusion pressure releases significantly lower amounts of intracellular enzymes suggesting that membrane damage can be limited to a certain extent by hyperthermic pretreatment.

\section{LITERATURE}

1. Bergmeyer H.U., and E. Bernt. UV assay for creatine kinase. In: Methods of Enzymology, Weinheim Verlag Chemie GmbH, pp 784-788, vol. 2, 1974

2. Bergmeyer H.U., and E. Bernt. UV assay for lactate dehydrogenase with pyruvate and NADH. In: Methods of Enzymology, Weinheim Verlag Chemie GmbH, pp 574-579, vol. 2, 1974

3. Cornelussen, R, W Spiering, J.H.G. Webers, L.G.A. de Bruin, R.S. Reneman, G.J. van der Vusse, and L.H.E.H. Snoeckx. Heat shock improves the ischemic tolerance of the hypertrophied rat heart. Am / Physiol 267: H1941-H1947, 1994

4. Currie, R.W., M. Karmazyn, M.Kloc, and K. Mailer. Heat-shock respunse is assuciated with enhanced post-ischemic recovery. Circ Res 63: 543-549, 1988.

5. Snoeckx, L.H.E.H., G.J. van der Vusse, W.A. Coumans, and R.S. Reneman. The effects of global ischemia and reperfusion on compensated hypertrophied hearts of aortabanded rats. / Mol Cell Cardiol 22: 1439-1451, 1990.

6. Snoeckx, L.H.E.H., G.J. van der Vusse, W.A. Coumans, P.H.M. Willemsen, and R.S. Reneman. Differences in ischemia tolerance between hypertrophied hearts of adult and aged spontaneously hypertensive rats. Cardiovasc Res 27: 874-881, 1993.

7. Snoeckx, L.H.E.H., G.J. van der Vusse, F.H. van der Veen, W.A. Coumans, and R.S. Reneman. Recovery of hypertrophied rat hearts after global ischemia and reperfusion at different perfusion pressures. Europ I Physiol (Pflugers Arch) 413: 303-312, 1989.

8. Yellon, D.M., E. Pasini, A. Cargoni, M.S. Marber, D.S. Latchman, and R. Ferrari. The protective role of heat stress in the ischemic and reperfused rabbit myocardium. / Mol Coll Cardiol 24: 895$907,1992$. 


\section{Chapter 4}

\section{HEAT SHOCK PROTECTS THE AGED HYPERTROPHIED AND NON-HYPERTROPHIED RAT HEART AGAINST ISCHEMIA AND REPERFUSION DAMAGE}




\section{ABSTRACT}

To explore the effects of heat shock (HS; $42^{\circ} \mathrm{C} ; 15 \mathrm{~min}$ ) in aged hypertrophied rat hearts, postischemic recovery was investigated 15 months after aortic constriction (Aob). Sham-operated animals (Sham) served as controls. 24 hours after HS ischemia was induced for $20 \mathrm{~min}$ in isolated Aob hearts and for 20 or $30 \mathrm{~min}$ in Sham hearts. After HS, postischemic recovery after respectively 20 and 30 min ischemia in Aob and Sham hearts was significantly better than in corresponding controls. In Aob hearts, cardiac output (CO), left ventricular developed pressure (LVDP) and left ventricular $+\mathrm{dP} / \mathrm{dt}_{\max }$ recovered to $33 \pm 26 \%$ (mean $\pm \mathrm{sd}$ ), $87 \pm 5 \%$, $72 \pm 12 \%$, respectively after HS, and to $5 \pm 8 \%, 22 \pm 39 \%, 17 \pm 29 \%$ of preischemic values, respectively in controls. In Sham hearts CO, LVDP and $+\mathrm{dP} / \mathrm{dt}_{\max }$ recovered to $20 \pm 20 \%, 75 \pm 8 \%$ and $59 \pm 15 \%$, respectively after HS and to $3 \pm 8 \%, 21 \pm 32 \%$, and $16 \pm 32 \%$ of preischemic values, respectively in controls. In HS hearts creatine kinase loss was not reduced. When Sham hearts were subjected to only $20 \mathrm{~min}$ ischemia, functional recovery was not different in heat-shocked and controls, indicative for a critical ischemia-length to establish the protective effect. These results indicate that HS pretreatment induces cardioprotection in the aged hypertrophied and nonhypertrophied rat heart.

\section{INTRODUCTION}

In mammalia hyperthermic treatment enhances the expression of a special set of proteins, called stress or heat shock proteins (HSPs), in almost all tissues [2], including the heart [16]. The presence of these proteins leads to improved tolerance of the heart against ischemia and reperfusion [7], not only in the non-hypertrophied adult heart but also in the hypertrophied adult heart [6]. The improved functional recovery of the heat-shocked adult non-hypertrophied rat heart after ischemia/ reperfusion has been attributed in particular to the presence of the major inducible 72 kilodalton heat shock protein, HSP72 $[14 ; 19 ; 20 ; 22]$, the expression of which is very low in non-shocked cardiac tissue [9]. In the aged hypertrophied and nonhypertrophied heart the expression of HSP72 upon heat shock was found to be significantly lower than in the adult heart [5], although the basal level of this protein is similar in both types of heart. The decreased ability of the aged hearts to produce HSP72 commensurates with an overall diminished synthesis of proteins in aged cells $[12 ; 23 ; 29]$.

The precise molecular mechanisms by which HSP72 protects cardiac tissue against an ischemic insult are as yet unknown. The protein is thought to protect the ischemic cell through stabilizing macromolecular structures and by the reactivation of denatured proteins. Under experimental conditions heat shock pretreatment is associated with increased postischemic coronary flow [6] and a reduction of the duration of postischemic arrhythmias $[6 ; 28]$.

If these changes are important in the hyperthermic pretreatment-mediated protection, especially hearts with impaired postischemic coronary vasodilation will benefit from this pretreatment. Such types of hearts are the adult hypertrophied [27] and aged (hypertrophied) heart $[15 ; 17]$. Since we already showed that heat shock improves the postischemic functional recovery of adult hypertrophied hearts [6], in the present study it was investigated whether heat shock pretreatment could also protect the aged compensated hypertrophied and the aged non-hypertrophied rat 
myocardium against an ischemic insult taking into account that the heat shockinduced expression of HSP72 occurs to a smaller extent than in non-senescent adult hearts [5].

\section{MATERIALS AND METHODS}

\section{Animal preparation}

The experiments were performed on 16-17 months old male Lewis rats. The animals were kept under restful housing conditions and had free access to food (Diet SRM-A, Hope farms) and water. The rats were housed in temperaturecontrolled rooms on an artificial light cycle of 12 hours. At the age of 6 weeks the animals were either aorta-banded (Aob) or sham-operated (Sham). All experiments were approved by the Institutional Animal Care and Use Committee of the University of Limburg, Maastricht, the Netherlands.

\section{Aorta-banding}

Six to seven weeks old rats were anesthetized with Narcovet ${ }^{\circledR}$ (pentobarbital 0.6 $\mathrm{mg} / \mathrm{g}$ body weight i.p.). Under sterile conditions the abdominal aorta was isolated suprarenally via a lateral abdominal incision and narrowed to about $40 \%$ of its original diameter by means of a Weck hemoclip [25]. In Sham-operated animals the aorta was only isolated. The abdomen was closed in layers and the animals were allowed to recover.

\section{Heat-shock protocol}

Between 14-15 months after surgery the rats were anesthetized with Hypnorm ${ }^{\circledR}$ $(0.01 \mathrm{mg} / 100 \mathrm{~g}$ body weight fentanyl plus $0.5 \mathrm{mg} / 100 \mathrm{~g}$ body weight fluanison s.c.) and placed on a temperature-controlled heating-pad until a rectal temperature of $42^{\circ} \mathrm{C}$ was reached (Sham $\mathrm{HS}: \mathrm{n}=14$, Aob $\mathrm{HS}_{\mathrm{S}} \mathrm{n}=5$ ). The animals were kept at this temperature for $15 \mathrm{~min}$. The control animals underwent the same protocol except for heating with the heating-pad (Sham $m_{C}$ n=14, Aob $: n=6$ ).

\section{Isolated heart perfusion}

Twenty-four hours following heat-shock or anesthesia the animals were lightly anesthetized with Hypnorm ${ }^{\circledR}(2 \mu \mathrm{g} / 100 \mathrm{~g}$ body weight fentanyl plus $0.1 \mathrm{mg} / 100 \mathrm{~g}$ body weight fluanison s.c.). After cervical dislocation the hearts were rapidly removed from the thorax and immediately immersed in an ice-cold Tyrode buffer solution, containing (in mmol/l): $\mathrm{NaCl}(130.0), \mathrm{KCl}$ (5.6), $\mathrm{CaCl}_{2}$ (2.2), $\mathrm{MgCl}_{2}$ (1.0), $\mathrm{NaH}_{2} \mathrm{PO}_{4}$ (1.2), $\mathrm{NaHCO}_{3}$ (28.6) and $\mathrm{D}(+)$ glucose (11.1). The hearts were quickly trimmed from lung and fat tissue, weighed and via the aorta connected to a perfusion apparatus installed in a thermostable cage $\left(37^{\circ} \mathrm{C}\right)$, as described previously [27; 30]. Retrograde perfusion was immediately started at a diastolic aortic perfusion pressure of $10.0 \mathrm{kPa}$ in Sham hearts and of $13.3 \mathrm{kPa}$ in Aob hearts. The hypertrophied hearts were perfused at a higher afterload level, since it was previously shown that a too low coronary perfusion pressure leads to depressed preischemic contractile function with prominent signs of anaerobic metabolism, like enhanced production of lactate [27]. The perfusion-buffer was continuously gassed with carbogen $\left(95 \% \mathrm{O}_{2}\right.$ and $5 \% \mathrm{CO}_{2} ; \mathrm{pO}_{2}>70 \mathrm{kPa} ; \mathrm{pH}$-range $\left.=7.32-7.45,37^{\circ} \mathrm{C}\right)$. The left atrium was connected to a second cannula so that the hearts were allowed to eject fluid through the aortic valve. Left atrial filling pressure was set at $1.33 \mathrm{kPa}$. 
Aortic pressure $\left(\mathrm{P}_{\mathrm{ao}}\right)$ was measured one $\mathrm{cm}$ above the aortic valve and left ventricular pressure through the apex of the heart with a small polyethylene catheter connected to an external pressure transducer (Spectramed, Bilthoven, the Netherlands). Left ventricular developed pressure (LVDP) was calculated as the difference between systolic and end-diastolic pressure. Left ventricular performance and relaxation were estimated from the positive and negative maximal first derivative of left ventricular pressure $\left(+d P / d t_{\max }\right.$ and $\left.-d P / d t_{\max }\right)$, respectively. The flow in the aortic cannula was measured with an extracorporeal flowprobe (diameter $3 \mathrm{~mm}$ ) connected to an electromagnetic flowmeter (Skalar, Delft, the Netherlands). Coronary flow (CF) was measured by timed collection of the coronary perfusate dripping from the heart. Cardiac output $(\mathrm{CO})$ was defined as the sum of aortic flow and coronary flow and, by definition, was zero when the hearts were perfused in the retrograde way. All hemodynamic variables were fed into a computer allowing the on-line calculation and presentation of data [24]. The hearts were electrically paced $(5 \mathrm{~Hz})$ throughout the experiment, except during ischemia and the first $10 \mathrm{~min}$ of reperfusion.

\section{Perfusion protocol}

After an initial stabilization period of $10 \mathrm{~min}$, during which the hearts were perfused retrogradely, the left atrial cannula was opened and the hearts were allowed to eject fluid from the left ventricle. The diastolic $P_{a o}\left(P_{a o}\right.$, diast $)$ was kept constant at $10.0 \mathrm{kPa}$ in Sham hearts and at $13.3 \mathrm{kPa}$ in Aob hearts throughout the experiment except for the ischemic period. The $\mathrm{P}_{\text {ao, diast }}$ was chosen to be $3.3 \mathrm{kPa}$ higher in the hypertrophied than in the non-hypertrophied heart to obtain similar preischemic cardiac performance in both types of hearts. Hearts ejecting small amounts of fluid $(<30 \mathrm{ml} / \mathrm{min}$ ) prior to the onset of ischemia were excluded from the study. For this reason, one heart had to be excluded from both the non-heated and the heat-shocked hypertrophied hearts. At the end of the $30 \mathrm{~min}$ preischemic period 4 groups of hearts (AobC: $n=6$; AobHS: $n=5$; ShamC: $n=8$; ShamHS: $n=8$ ) were subjected to $20 \mathrm{~min}$ of global normothermic ischemia $\left(37^{\circ} \mathrm{C}\right)$ by crossclamping the left atrial and aortic cannulas. In 2 separate groups of Sham hearts (Shamc: $n=6$; Sham ${ }_{\text {HS }} n=6$ ) a $30 \mathrm{~min}$ period of global ischemia was applied. Hearts were immersed in water of $37^{\circ} \mathrm{C}$ throughout the entire ischemic period. After ischemia, the hearts were reperfused retrogradely during $15 \mathrm{~min}$ followed by antegrade perfusion during $30 \mathrm{~min}$, at identical $\mathrm{P}_{\mathrm{ao}}$, diast values as during the preischemic period. The maximum steady state values attained during the antegrade preischemic and postischemic perfusion periods were used for calculation of the percentage recovery of the hemodynamic variables. Coronary effluent samples were immediately frozen in liquid nitrogen and stored at $-80^{\circ} \mathrm{C}$ for later biochemical analysis. In the various groups all hearts were studied at random.

\section{Biochemical analysis}

The coronary effluent samples were monitored for the presence of creatine kinase (CK) as a marker for irreversible cell damage. Enzyme activity was measured spectrophotometrically according to Bergmeyer and Bernt, using a Cobas Bio autoanalyzer [3].

\section{Statistics}

All values are expressed as mean values \pm sd. Differences between the hemodynamic variables in heat-shocked and non-heated groups of hearts as well as 
differences between hypertrophied and non-hypertrophied groups of hearts were evaluated for statistical significance using the Mann-Whitney U-test. Differences within the same group of hearts were evaluated by the Wilcoxon matched pairs signed-ranks test. Values of $\mathrm{p}<0.05$ were considered to be statistically significant.

\section{RESULTS}

\section{Degree of hypertrophy}

Fresh heart weight (prior to cannulation) and heart weight to body weight ratio were significantly higher in both Aob groups than in both Sham groups (Table 1). Aortic banding resulted in a degree of hypertrophy of the total heart of $22 \%$. Because of the edema formation during perfusion, heart weight could reliable be determined only before the onset of perfusion. Therefore, the weight of the left ventricle could not be determined separately, but it is conceivable that it was more than $22 \%$ higher in the hypertrophied than in the non-hypertrophied hearts. No significant differences in lung weight $(2.04 \pm 0.47 \mathrm{~g}$ and $1.84 \pm 0.27 \mathrm{~g}$; hypertrophied and non-hypertrophied, respectively) and liver weight $(13.1 \pm 0.9 \mathrm{~g}$ vs $13.6 \pm 2.3 \mathrm{~g})$ were observed between hypertrophied and non-hypertrophied hearts. Other clinical signs of cardiac decompensation, such as ascites or fluid in the thoracic cavity, were absent in the animals used for this study. Two animals that were excluded (see perfusion protocol) had ascites and fluid in the thoracic cavity. At visual inspection, however, all non-hypertrophied and hypertrophied hearts exhibited small fibrotic regions in the left ventricular wall, which is absent in normal young and adult hearts.

Table 1: Heart weight ( $\mathrm{HW}$ ), body weight $(B W)$ and heart weight to body weight ratio (HW/BW) in anesthetized, control (C) and heat-shocked (HS) aorta-banded (Aob) and sham-operated (Sham) rats.

\begin{tabular}{|c|c|c|c|}
\hline & $\begin{array}{l}\text { Heart weight } \\
\text { (g) }\end{array}$ & $\begin{array}{c}\text { Body weight } \\
\text { (g) }\end{array}$ & $\begin{array}{l}\mathrm{HW} / \mathrm{BW} \\
\left(1^{*} 10^{-2}\right)\end{array}$ \\
\hline Aobc $(n=6)$ & $2.73 \pm 0.43^{*}$ & $529 \pm 44$ & $0.52 \pm 0.06^{*}$ \\
\hline AobHS $(n=5)$ & $2.71 \pm 0.29^{*}$ & $520 \pm 44$ & $0.52 \pm 0.06^{*}$ \\
\hline Shamc $(n=14)$ & $2.20 \pm 0.18$ & $538 \pm 63$ & $0.41 \pm 0.04$ \\
\hline ShamHS $(n=14)$ & $2.30 \pm 0.13$ & $566 \pm 48$ & $0.41 \pm 0.03$ \\
\hline
\end{tabular}

Data are presented as mean values \pm s.d. * : significantly different from the values in the corresponding Sham group.

\section{Hemodynamics}

Preischemic hemodynamic performance: Table 2 shows the steady state values of the preischemic hemodynamic variables of hypertrophied and non-hypertrophied hearts. Perfusing the Aob hearts at a diastolic aortic pressure $3.3 \mathrm{kPa}$ higher than the Sham hearts resulted in similar preischemic function. Except for left ventricular developed pressure (LVDP), which was significantly lower in 3 out of the 4 Sham groups compared to the Aob groups, no differences in the hemodynamic variables were observed between the corresponding groups. Despite the fact that the Sham hearts belonging to the 4 experimental groups were perfused under identical preischemic conditions, LVDP (Table 2) and coronary flow (Table 3) were slightly 
but significantly lower in the hearts belonging to the 30 min ischemia group than in those belonging to the $20 \mathrm{~min}$ ischemia group. The other hemodynamic variables, such as cardiac output and positive and negative $\mathrm{dP} / \mathrm{dt}_{\max }$, were similar in all 4 Sham groups. Preischemic coronary flow was significantly lower in Shamrs hearts of the $30 \mathrm{~min}$ ischemia group than in Aob HS hearts (Table 3).

Table 2: Preischemic hemodynamic variables in isolated hearts of anesthetized control (C) and heatshocked (HS) aorta-banded (Aob) and sham-operated (Sham) rats.

\begin{tabular}{|c|c|c|c|c|c|c|}
\hline Groups & \multicolumn{4}{|c|}{$20 \mathrm{~min}$ of ischemia } & \multirow{2}{*}{\multicolumn{2}{|c|}{30 min of ischemia }} \\
\hline $\mathrm{P}_{\mathrm{ao}}(\mathrm{kPa})$ & 13 & & & .0 & & \\
\hline Hearts & $\begin{array}{l}\text { Aobc } \\
(n=6)\end{array}$ & $\begin{array}{c}\text { Aob }{ }_{H S} \\
(n=5)\end{array}$ & $\begin{array}{c}\text { Shamc } \\
(n=8)\end{array}$ & $\begin{array}{l}\text { ShamHS } \\
\qquad(n=8)\end{array}$ & $\begin{array}{l}\text { Shamc } \\
(n=6)\end{array}$ & $\begin{array}{l}\text { ShamHS } \\
\qquad(n=6)\end{array}$ \\
\hline 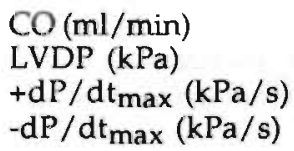 & $\begin{array}{c}82 \pm 16 \\
14.2 \pm 2.0 \\
678 \pm 185 \\
431 \pm 112\end{array}$ & $\begin{array}{c}85 \pm 10 \\
14.0 \pm 0.7 \\
618 \pm 31 \\
448 \pm 65\end{array}$ & $\begin{array}{c}94 \pm 17 \\
12.4 \pm 1.1 \\
676 \pm 131 \\
439 \pm 66\end{array}$ & $\begin{array}{c}92 \pm 7 \\
11.8 \pm 0.5 \# \\
666 \pm 76 \\
444 \pm 51\end{array}$ & $\begin{array}{c}94 \pm 22 \\
10.9 \pm 0.9 \#+ \\
588 \pm 86 \\
425 \pm 50\end{array}$ & $\begin{array}{c}88 \pm 11 \\
11.4 \pm 0.5 \# \\
629 \pm 59 \\
422 \pm 41\end{array}$ \\
\hline
\end{tabular}

The data are expressed as mean values \pm s.d. $\mathrm{CO}=$ cardiac output, $\mathrm{LVDP}=$ left ventricular developed pressure, $+\mathrm{dP} / \mathrm{dt}_{\max }$ and $-\mathrm{dP} / \mathrm{dt}_{\max }=$ respectively positive and negative maximal first derivative of left ventricular pressure; $\mathrm{Pao}_{\mathrm{ao}}=$ diastolic aortic pressure. \#: significantly different from the corresponding Aob group; $t$ : significantly different from the corresponding Sham groups after $20 \mathrm{~min}$ of ischemia.

Table 3: Coronary flow values ( $\mathrm{ml} / \mathrm{min} \cdot \mathrm{g}$ wet heart weight) in isolated hearts of anesthetized control (C) and heat-shocked (HS) aorta-banded (Aob) and sham-operated (Sham) rats.

Groups

Pao $(\mathrm{kPa})$

Hearts

Preischemic

$\mathrm{t}=10 \mathrm{~min}^{\mathrm{a}}$

$t=20 \min ^{b}$

Postischemic

$\mathrm{t}=5 \mathrm{~min}^{\mathrm{a}}$

$t=10 \mathrm{~min}^{\mathrm{a}}$

$\mathrm{t}=15 \mathrm{~min}^{\mathrm{a}}$

$\mathrm{t}=30 \mathrm{~min}^{\mathrm{b}}$
$20 \mathrm{~min}$ of ischemia

13.3

$\begin{array}{lc}\text {AAbC}_{(n=6)} & \begin{array}{c}\text { AobHS } \\ (n=5)\end{array}\end{array}$

$\begin{array}{cc}8.1 \pm 1.3 & 9.5 \pm 0.3^{*} \\ 10.0+2.0 & 12.0+2.0\end{array}$

$6.3 \pm 3.0$

\section{$9.7 \pm 1.7$}

$7.7 \pm 2.3$

$10.6 \pm 1.1^{*}$

$7.2+1.8$

$10.8 \pm 0.8^{*}$

$8.4 \pm 2.2 \quad 10.9 \pm 2.6$
$30 \mathrm{~min}$ of ischemia

$$
10.0
$$

\begin{tabular}{cccc}
\hline $\begin{array}{c}\text { ShamC } \\
(n=8)\end{array}$ & $\begin{array}{c}\text { ShamHS } \\
(n=8)\end{array}$ & $\begin{array}{c}\text { ShamC } \\
(n=6)\end{array}$ & $\begin{array}{c}\text { ShamHS } \\
(n=6)\end{array}$ \\
\hline
\end{tabular}

$\begin{array}{cc}7.9 \pm 1.2 & 8.2 \pm 0.7 \# \\ 11.8 \pm 1.3 & 11.6 \pm 1.8 \\ & \\ 8.9 \pm 1.8 \# & 8.8 \pm 1.0 \\ 10.7 \pm 2.5 \# & 10.8 \pm 0.8 \\ 10.4 \pm 1.8 \# & 10.7 \pm 1.0 \\ 10.1 \pm 1.1 & 10.6 \pm 0.6\end{array}$

$6.9 \pm 0.4 \#+$

$7.2 \pm 0.3+\#$ $10.5 \pm 1.4+9.7 \pm 0.8+\#$

$6.3 \pm 1.4+\quad 7.7 \pm 1.1$ \#

$7.3 \pm 1.3+10.5 \pm 2.5^{*}$

$7.4 \pm 1.2+\quad 9.9 \pm 1.9^{*}$

$8.1 \pm 2.1 \quad 9.7 \pm 0.6^{*} \dagger$

The data are expressed as mean values \pm s.d. a: values recorded during the retrograde perfusion period; $\mathrm{b}$ : values recorded during the antegrade perfusion period; $\mathrm{P}_{\mathrm{ao}}=$ diastolic aortic pressure. ": significantly different from the corresponding control group; \#: significantly different from the corresponding Aob group; t: significantly different from the corresponding Sham groups after $20 \mathrm{~min}$ of ischemia. 
Postischemic hemodynamic performance: Table 4 shows that postischemic recovery of all hemodynamic variables was significantly less in non-heated hypertrophied $(A o b c)$ hearts than in the corresponding non-heated, nonhypertrophied hearts (Shamc;20 min of ischemia). Heat shock significantly improved the functional outcome of AobHS hearts when compared to the corresponding $A_{0} b_{C}$ hearts. Heat shock did not improve the moderate degree of recovery of the Shamc hearts subjected to $20 \mathrm{~min}$ of ischemia (ShamHs and Shamc). It is of interest to note that the degree of recovery of $\mathrm{CO}$, and positive and negative $\mathrm{dP} / \mathrm{dt}_{\max }$ was similar in the AobHS group and in the ShamHS and Shamc groups subjected to $20 \mathrm{~min}$ of ischemia. Prolongation of the ischemic period to 30 min in the Sham group resulted in a severely depressed postischemic functional recovery. In this situation heat shock pretreatment resulted in a substantial improvement of postischemic functional performance (ShamHS, $30 \mathrm{~min}$ vs Shamc, $30 \mathrm{~min})$.

Table 4: Postischemic percentage recovery of the hemodynamic variables and duration of electrical instability in hearts of anesthetized control (C) and heat-shocked (HS) aorta-banded (Aob) and shamoperated (Sham) rats.

\begin{tabular}{|c|c|c|c|c|c|c|}
\hline Groups & \multicolumn{4}{|c|}{$20 \mathrm{~min}$ of ischemia } & \multirow{2}{*}{\multicolumn{2}{|c|}{$\frac{30 \mathrm{~min} \text { of ischemia }}{10.0}$}} \\
\hline $\mathrm{P}_{\text {ao }}(\mathrm{kPa})$ & \multicolumn{2}{|c|}{13.3} & \multicolumn{2}{|c|}{10.0} & & \\
\hline Hearts & $\begin{array}{l}\text { Aobc } \\
(n=6)\end{array}$ & $\begin{array}{c}\text { AobHS } \\
(n=5)\end{array}$ & $\begin{array}{l}\text { Shamc } \\
(n=8)\end{array}$ & $\begin{array}{c}\text { ShamHS } \\
(n=8)\end{array}$ & $\begin{array}{l}\text { Shamc } \\
(n=6)\end{array}$ & $\begin{array}{c}\text { ShamHS } \\
(n=6)\end{array}$ \\
\hline $\mathrm{CO}$ & $5 \pm 8$ & $33 \pm 26^{*}$ & $39 \pm 17 \#$ & $37 \pm 17$ & $3 \pm 8+$ & $20 \pm 20^{*}$ \\
\hline LVDP & $22 \pm 39$ & $87 \pm 5^{*}$ & $78 \pm 4 \#$ & $78 \pm 8 \#$ & $21 \pm 32 t$ & $75 \pm 8 * \#$ \\
\hline$+\mathrm{dP} / \mathrm{dt}_{\max }$ & $17 \pm 29$ & $72 \pm 12^{*}$ & $64 \pm 8 \#$ & $65 \pm 11$ & $16 \pm 32 t$ & $59 \pm 15^{*}$ \\
\hline$-\mathrm{dP} / \mathrm{d} t_{\max }$ & $17 \pm 29$ & $67 \pm 9^{*}$ & $66 \pm 11 \#$ & $64 \pm 12$ & $15 \pm 23+$ & $55 \pm 10^{*}$ \\
\hline $\begin{array}{l}\text { Electrical instability } \\
\text { (min) }\end{array}$ & $38.8 \pm 9.8$ & $19.6 \pm 8.9^{*}$ & $17.9 \pm 7.8 \#$ & $13.6 \pm 6.4$ & $37.8 \pm 11.1$ & $29.2 \pm 3.9 \#+$ \\
\hline
\end{tabular}

The data are expressed as mean values \pm s.d. $\mathrm{CO}=$ cardiac output, $\mathrm{LVDP}=$ left ventricular developed pressure; $+\mathrm{dP} / \mathrm{dt}_{\max }$ and $-\mathrm{dP} / \mathrm{dt}_{\max }=$ respectively positive and negative maximal first derivative of left ventricular pressure; $\mathrm{P}_{\mathrm{ao}}=$ diastolic aortic pressure. ": significantly different from the corresponding control group; \#: significantly different from the corresponding Aob group; t: significantly different from the corresponding Sham groups after 20 min of ischemia.

During the first $15 \mathrm{~min}$ of reperfusion, when the hearts were perfused retrogradely, reactive hyperemia was completely absent in Aobc hearts, whereas in Aob ${ }_{H S}$ hearts a modest reactive hyperemic response was observed (Figure 1). The differences in absolute coronary flow values between Aob $\mathrm{C}$ and $\mathrm{Aob}_{\mathrm{HS}}$ hearts were statistically significant at the $10^{\text {th }}$ and $15^{\text {th }}$ min after the start of reperfusion (Table 3). During subsequent antegrade perfusion no differences in coronary flow between Aob $\mathrm{HS}$ and $\mathrm{Aob}_{\mathrm{C}}$ hearts were observed.

In both Shamc and ShamHS hearts subjected to $20 \mathrm{~min}$ of ischemia, initial reperfusion was characterized by a prominent hyperemic response (Figure 1). However, when the ischemic period was prolonged to $30 \mathrm{~min}$, reactive hyperemia was completely absent in Shamc hearts. In contrast, $5 \mathrm{~min}$ after reperfusion the 
absolute coronary flow values were significantly higher in ShamHs hearts than in the corresponding Shamc hearts (Table 3).

\section{Electrical stability}

In all hearts the initial reperfusion phase was characterized by alternating periods of arrhythmias and ventricular fibrillation. The total duration of electrical instability was significantly reduced in AobHS hearts compared to AobC hearts (Table 4). Compared to the control groups, in both groups of non-hypertrophied hearts heat shock tended to reduce the duration of the electrical disturbances but the level of statistical significance was not reached. In Aob ${ }_{C}$ hearts as well as in Sham $C$ hearts belonging to the $30 \mathrm{~min}$ of ischemia group, only 2 hearts showed complete electrical and stable mechanical recovery within the $45 \mathrm{~min}$ of reperfusion. In all the other groups, hearts regained normal sinus rhythm and some degree of mechanical cardiac function within the $45 \mathrm{~min}$ reperfusion period.

Table 5: Total preischemic (over $30 \mathrm{~min}$ ) and postischemic (over $45 \mathrm{~min}$ ) loss of creatine kinase (CK) of isolated hearts of anesthetized control (C) and heat-shocked (HS) aorta-banded (Aob) and shamoperated (Sham) hearts.

\begin{tabular}{|c|c|c|c|c|c|c|}
\hline Groups & \multicolumn{4}{|c|}{$20 \mathrm{~min}$ of ischemia } & \multirow{2}{*}{\multicolumn{2}{|c|}{$\frac{30 \mathrm{~min} \text { of ischemia }}{10.0}$}} \\
\hline $\mathrm{P}_{\mathrm{ao}}(\mathrm{kPa})$ & \multicolumn{2}{|c|}{13.3} & \multicolumn{2}{|c|}{10.0} & & \\
\hline Hearts & $\begin{array}{l}\text { Aobc } \\
(n=6)\end{array}$ & $\begin{array}{c}\text { AobHS } \\
(n=5)\end{array}$ & $\begin{array}{c}\text { Shamc } \\
(n=8)\end{array}$ & $\begin{array}{c}\text { ShamHS } \\
(n=8)\end{array}$ & $\begin{array}{c}\text { Sham } C \\
(n=6)\end{array}$ & $\begin{array}{c}\text { ShamHS } \\
\qquad(n=6)\end{array}$ \\
\hline Preischemia & $2.2 \pm 0.7$ & $2.8 \pm 1.5$ & $3.0 \pm 1.6$ & $2.6 \pm 0.8$ & $2.4 \pm 0.7$ & $2.8 \pm 1.4$ \\
\hline Postischemia & $33.5 \pm 3.7$ & $34.4 \pm 9.5$ & $34.6 \pm 7.2$ & $68.8 \pm 8.0^{*} \#$ & $35.8 \pm 13.7$ & $46.1 \pm 15.5+$ \\
\hline
\end{tabular}

The data are expressed as mean values \pm s.d. $C K$ is expressed as Units per grams of wet heart tissue weight; $\mathrm{P}_{\mathrm{ao}}=$ diastolic aortic pressure. *: significantly different from the corresponding control group; \#: significantly different from the corresponding Aob group; t: significantly different from the corresponding Sham groups after $20 \mathrm{~min}$ of ischemia.

\section{Enzyme release}

The preischemic creatine kinase (CK) loss was low and comparable in all groups (Table 5). After ischemia and reperfusion an increased release of this cytosolic enzyme was observed in all hearts. Heat shock pretreatment did not change the amount of CK released during the reperfusion phase in Aob ${ }_{H S}$ and AobC hearts. Evenso, postischemic release of $C K$ was not different in Sham $\mathrm{HS}_{\mathrm{S}}$ and Sham $\mathrm{C}$ hearts belonging to the $30 \mathrm{~min}$ ischemia group. Following $20 \mathrm{~min}$ of ischemia, however, significantly more enzyme was lost in ShamHS hearts than in the corresponding Shamc hearts.

\section{DISCUSSION}

The findings in the present study show that heat shock pretreatment protects the aged hypertrophied rat heart against ischemia and reperfusion damage. When the same duration of ischemia, i.e. $20 \mathrm{~min}$, is applied in the hypertrophied and non- 
hypertrophied hearts heat shock pretreatment only confers cardioprotection in the hypertrophied heart, despite the fact that the hypertrophied heart has to eject against an afterload which is $3.3 \mathrm{kPa}$ higher than in the non-hypertrophied heart. However, after a $30 \mathrm{~min}$ period of ischemia hyperthermic pretreatment also induces improvement of postischemic cardiac function in the non-hypertrophied heart. In the heat-shocked hearts, displaying higher postischemic functional recovery, coronary flow was found to be significantly higher compared to the corresponding non-heated control hearts. In the heat-shocked hypertrophied hearts the improved hemodynamic function after ischemia was not associated with reduced release of cytosolic proteins from the heart.

\section{Cardiac hypertrophy}

Although aortic coarctation was applied 14-15 months before the animals were studied and in this model systemic mean blood pressure may have increased to values above $21 \mathrm{kPa}$ [25], this long-standing hypertension did not lead to cardiac decompensation in the majority of the animals. In fact, of the 13 hypertrophied hearts studied only 2 hearts had to be excluded from the study because of decompensation as indicated by the low in vitro determined, preischemic cardiac output values (50 to $60 \mathrm{ml} / \mathrm{min}$ lower than in the other hearts), and the presence of ascitis, increased lung weight and fluid in the thoracic cavity. The hearts of the aorta-banded rats in the present study have to be considered as moderately hypertrophied because of the limited (22\%) increase in heart weight to body weight ratio. Since the heart weight to body weight ratios in the aorta-banded and Shamoperated rats were similar to the respective values found in adult rats of 3-4 months of age $[6 ; 26]$, the preischemic cardiac output values were normal and no ascitis and increased lung and liver weigth was observed, it may be concluded that longstanding systemic hypertension does in general not per se lead to cardiac decompensation or heart failure. In this regard it is interesting to note that Bing and coworkers have shown that decompensation can even be absent in spontaneously hypertensive rats at the age of 19 months [4].

\section{Perfusion pressure}

In this study, hypertrophied hearts were perfused at a higher afterload level, because earlier studies in our laboratory have shown that in aged hypertrophied hearts a relatively low coronary perfusion pressure leads to depressed preischemic contractile function with prominent signs of anaerobic metabolism [25]. Furthermore, perfusion of the hypertrophied heart at an afterload level of $3.3 \mathrm{kPa}$ higher than the non-hypertrophied heart better mimics the in-vivo perfusion conditions. Besides, at these different perfusion pressures in the preischemic period comparable coronary flows per gram heart weight and comparable mechanical function could be obtained in both heart types. The aged hypertrophied heart seems to be more sensitive to ischemia, because in the non-heated control hearts postischemic functional recovery was better in non-hypertrophied than hypertrophied hearts following $20 \mathrm{~min}$ of ischemia, at their ambient pressure.

\section{Heat shock pretreatment}

It is now widely accepted that hyperthermic pretreatment can protect the adult heart against ischemia and accompanying reperfusion damage $[7 ; 10 ; 32]$. Despite the fact that a direct correlation was observed between the cardiac amount of HSP72 induced by heat shock and the degree of myocardial protection $[14 ; 20 ; 22]$ and that the aged heart is less capable of expressing the inducible HSP72 upon heat shock [5;21] in the 
present study heat stress protects the aged hypertrophied and non-hypertrophied heart against ischemia and reperfusion. In the present study, the levels of the HSP72 protein were not determined, but the results obtained indicate that heat pretreatment does not lose its beneficial effects in aged tissues, even when pathological conditions like long-standing cardiac hypertrophy are present.

Since protection in non-hypertrophied hearts was effective after $30 \mathrm{~min}$ and not after 20 min of ischemia, differences in ischemia duration are apparently crucial for the functional postischemic outcome of hyperthermically pretreated hearts. Why non-hypertrophied hearts are not protected against the insult induced by 20 min of ischemia and $45 \mathrm{~min}$ of reperfusion following hyperthermic pretreatment is unclear. It is possible that a critical extent of ischemic injury has to be present to bring out the beneficial effect of hyperthermic pretreatment. Indeed, in the 20 min ischemia group the functional recovery of the control hearts was already as high as in the heated hearts of all 3 groups investigated. These results again illustrate the dependency of heat shock-mediated improvement of postischemic functional recovery on the severity of the ischemic insult, as was shown earlier by other investigators $[8 ; 10 ; 11 ; 20 ; 31 ; 33]$.

In both heat-shocked hypertrophied and non-hypertrophied aged hearts the maximal postischemic functional recovery of cardiac output never exceeded $40 \%$. This is in contrast with the higher postischemic recovery previously found in adult hearts $(80 \%$ and $60 \%$ in non-hypertrophied and hypertrophied hearts, respectively) [6]. This may indicate that in aged heart less HSP72 is induced. Alternatively, the efficacy of induced HSP72 to confer protection against ischemia/reperfusion in the aged hearts might be decreased.

\section{Coronary flow}

The increased vulnerability of the aged hypertrophied heart to ischemia can be attributed in part to a diminished maximal vasodilator response [18]. In the present study hyperthermic pretreatment leads to a prominent hyperemic response in those hearts in which cardioprotection occurred. In earlier experiments we have shown that hyperthermic pretreatment is accompanied by an increased and more homogeneous postischemic myocardial perfusion compared to non-treated hearts [6]. In a more recent study a lower coronary resistance has been found in hearts, in which HSP72 was (over)expressed constitutively [22]. The mechanisms by which the coronary vascular resistance is lowered in the hyperthermically pretreated heart are as yet unknown. In addition, the precise site of the above mentioned action has still to be determined. It may quite well be that an endothelium-dependent vasoactive mechanism is responsible, since Amrani and coworkers [1] have shown that endothelial function (tested by infusion of 5-hydroxytryptamin) was better preserved during reperfusion in the heat-shocked than in the control heart. The endogenous vasodilating compound adenosine is probably not involved, since Currie and coworkers [10] did not find any difference in tissue content of this metabolite between heated and non-heated hearts. A more likely candidate for heat shock-induced coronary vasodilation is nitric oxide. In this respect, in the splanchnic venous bed the concentration of nitric oxide was found to be increased upon heat shock [13]. It is not known, however, whether the increased synthesis of nitric oxide also occurs in the coronary vascular bed and whether it is still increased 24 hours after heat shock. 
Enzyme release

Although hyperthermically pretreated hypertrophied and non-hypertrophied hearts showed improved postischemic mechanical performance, the loss of intracellular enzymes was not mitigated. These findings may be explained by the above mentioned inhomogeneities in coronary flow distribution in reperfused aged hearts. Lack of adequate reperfusion of certain regions of the postischemic hypertrophied myocardium may delay or prevent the washout of intracellular enzymes. Indeed, the coronary vasodilatory reserve is already impaired in aged hearts [18]. If the total loss of creatine kinase was related to the total content of this

$20 \mathrm{~min}$ ischemia

Aob $_{\mathrm{C}}$ Aob $_{\mathrm{HS}}$ Sham $\mathrm{C}$ Sham
$30 \mathrm{~min}$ ischemla

$$
\text { Sham }{ }_{\mathrm{C}} \text { Sham }_{\mathrm{HS}}
$$

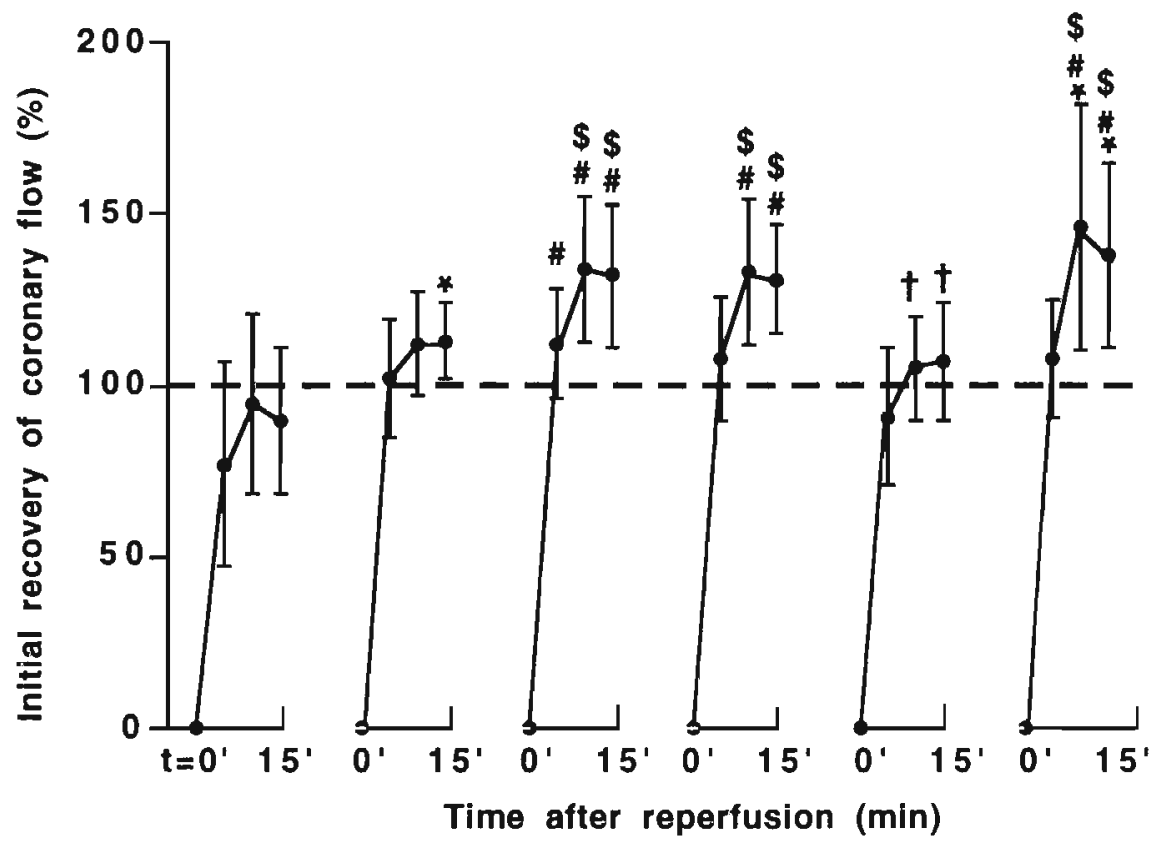

Figure 1: Percentage recovery of coronary flow during the first $15 \mathrm{~min}$ of reperfusion in heatshocked (HS) and anesthetized (C) hypertrophied (Aob) and non-hypertrophied (Sham) rat hearts; ${ }^{*}$ : significantly different from the values in the corresponding control group; : significantly different from the values in the Aob group; $t$ : significantly different from the values in the corresponding Sham groups after $20 \mathrm{~min}$ of ischemia; $\$$ : significantly different from the values, recorded during the preischemic retrograde perfusion period.

enzyme in the heart, on the average $10 \%$ was lost during reperfusion. Generally spoken, the highest amounts were lost from hearts with a prominent hyperemic response. The creatine kinase release into the coronary effluent was significantly higher in heat-shocked non-hypertrophied hearts than in non-heated control hearts, when subjected to $20 \mathrm{~min}$ of ischemia. So no conclusive evidence can be presented on cellular membrane integrity in the aged myocardium as doubts can be 
raised about the applicability of cytosolic enzyme release as a marker of irreversible cellular damage under these circumstances.

In conclusion, the findings in the present study indicate that hyperthermic pretreatment improves the tolerance of the aged non-hypertrophied and compensated hypertrophied heart to ischemic and reperfusion damage. Although the mechanism(s) underlying the heat shock-mediated cardioprotection are as yet unknown, the present findings strongly suggest that improvement of postischemic coronary flow may be instrumental in heat shock-induced protection against the deleterious effects of ischemia and reperfusion.

\section{LITERATURE}

1. Amrani, M., J. Corbett, N.J. Allen, J. O'Shea, S.Y. Boateng, M.J. Dunn and M.H. Yacoub. Induction of heat-shock proteins enhances myocardial and endothelial functional recovery after prolonged cardioplegic arrest. Ann Thorac Surg 57: 157-160, 1994.

2. Beck, S., C. Paidas, H. Tan, J. Yang and A. De Maio. Depressed expression of the inducible form of HSP70 (HSP72) in brain and heart after in vivo heat shock. Am / Physiol (Regulatory Integrative Comp Physiol) 269: R608-R613, 1995.

3. Bergmeyer, H.U. and E. Bernt. UV assay for creatine kinase. In: Methods of Enzymology, Weinheim Verlag Chemie GmbH, pp. 784-788, 1974.

4. Bing, O.H., W.W. Brooks, K.G. Robinson, M.T. Slawsky, J.A. Hayes, S.E. Litwin, S. Sen and CH Conrad. The spontaneously hypertensive rat as a model of the transition from compensated left ventricular hypertrophy to failure. / Mol Cel Cardiol 27: 383-396, 1995.

5. Bongrazio, M., L. Comini, G. Gaia, T. Bachetti and R. Ferrari. Hypertension, aging, and myocardial synthesis of heat shock protein 72. Hypertension 24: 620-624, 1994

6. Cornelussen, R., W. Spiering, J.H.G. Webers, L.G.A. de Bruin, R.S. Reneman, G.J. van der Vusse and L.H.E.H. Snoeckx. Heat shock improves the ischemic tolerance of the hypertrophied rat heart. Am J Physiol 267: H1941-H1947, 1994.

7. Currie, R.W., M. Karmazyn, M. Kloc and K. Mailer. Heat-shock response is associated with enhanced post-ischemic recovery. Circ Res 63: 543-549, 1988.

8. Currie, R.W. and M. Karmazyn. Improved post-ischemic ventricular recovery in the absence of changes in energy metabolism in working rat hearts following heat-shock. / Mol Cell Cardiol 22: 631-6, 1990.

9. Currie, R.W. and R.M. Tanguay. Analysis of RNA for transcripts for catalase and SP71 in rat hearts after in vivo hyperthermia. Biochem Cell Biol 69: 375-382, 1991.

10. Currie, R.W., R.M. Tanguay and J.G. Kingma Jr. Heat-shock response and limitation of tissue necrosis during occlusion/reperfusion in rabbit hearts. Circulation 87: 963-71, 1993.

11. Donnelly, T.J., R.E. Sievers, F.L. Vissern, W.J. Welch and C.L. Wolfe. Heat-shock protein induction in rat hearts. A role for improved myocardial salvage after ischemia and reperfusion. Circulation 85: 769-778, 1991.

12. Effron, M.B., G.M. Bhatnagar, H.A. Spurgeon, G .Ruaño-Arroyo and E.G. Lakatta. Changes in myosin isoenzymes, ATPase activity, and contraction duration in rat cardiac muscle with aging can be modulated by thyroxine. Circ Res 60: 238-245, 1987.

13. Hall, D.M., G.R. Buettner, R.D. Matthes and C.V. Gisolfi. Hyperthermia stimulates nitric oxide formation: electron paramagnetic resonance detection of.NO-heme in blood. / Appl Physiol 77: 548-553, 1994.

14. Hutter, M.M., R.E. Sievers, V. Barbosa and C.L. Wolfe. Heat-shock protein induction in rat hearts. A direct correlation between the amount of heat-shock protein induced and the degree of myocardial protection. Circulation 89: 355-60, 1994.

15. Isoyama, S., N. Ito, M. Komatsu, Y. Nitta, K. Abe, M. Aoki and T. Takishima. Responses to hernodynamic stress in the aged heart. Jpn Heart J 35: 403-418, 1994.

16. Knowlton, A.A. The role of heat shock proteins in the heart. / Mol Cel Cardiol 27: 121-131, 1995.

17. Lakatta, E.G. Do hypertension and aging have a similar effect on the myocardium ? Circulation 75: 169-177, 1987.

18. Lakatta, E.G. Cardiovascular regulatory mechanisms in advanced age. Physiol Reo 73: 413-467, 1993 
19. Marber, M.S., R. Mestril, S-H. Chi, M.R. Sayen, D.M. Yellon and W.H. Dillmann. Overexpression of the rat inducible 70-kD heat stress protein in a transgenic mouse increases the resistance of the heart to ischemic injury. / Clin Invest 95: 1446-1456, 1995.

20. Marber, M.S., D.S. Latchman, J.M. Walker and D.M. Yellon. Cardiac stress protein elevation 24 hours after brief ischemia or heat stress is associated with resistance to myocardial infarction. Circulation 88: 1264-72, 1993.

21. Nitta, Y., K. Abe, M. Aoki, I. Ohno and S. Isoyama. Diminished heat shock protein $70 \mathrm{mRNA}$ induction in aged rats after ischemia. Am / Physiol 267: H1795-H1803, 1994.

22. Plumier, J.C.L., B.M. Ross, R.W. Currie, C.E. Angelidis, H. Kazlaris, G. Kollias and G.N. Pagoulatos. Transgenic mice expressing the human heat shock protein 70 have improved postischemic myocardial recovery. J Clin Invest 95: 1854-1860, 1995.

23. Rattan, S.I., A. Derventzi and B.F. Clark. Protein synthesis, posttranslational modifications, and aging. Ann NY Acad Sci 663: 48-62, 1992.

24. Snoeckx, L.H.E.H., J.J. Schrijen, M. van Bilsen, W.J. Lammers, T. van der Nagel, G.J. van der Vusse and RS. Reneman. A microcomputer system for hemodynamic measurements in isolated, working rat hearts. Comp Biol Med 4: 301-309, 1986.

25. Snoeckx, L.H.E.H., G.J. van der Vusse, W.A. Coumans and R.S. Reneman. The effects of global ischemia and reperfusion on compensated hypertrophied hearts of aortabanded rats. / Mol Cell Cardiol 22: 1439-1451, 1990.

26. Snoeckx, L.H.E.H., G.J. van der Vusse, W.A. Coumans, P.H.M. Willemsen and R.S. Reneman. Differences in ischemia tolerance between hypertrophied hearts of adult and aged spontaneously hypertensive rats. Cardiovasc Res 27: 874-881, 1993.

27. Snoeckx, L.H.E.H., G.J. van der Vusse, F.H. van der Veen, W.A. Coumans and R.S. Reneman. Recovery of hypertrophied rat hearts after global ischemia and reperfusion at different perfusion pressures. Eur J Physiol (Pfligers Arch) 413: 303-312, 1989.

28. Steare, S.E. and D.M. Yellon. The protective effect of heat stress against reperfusion arrhythmias in the rat. I Mol Cell Cardiol 25: 1471-1481, 1993.

29. Takahashi, T., H. Schunkert and S. Isoyama. Age-related differences in the expression of protooncogene and contractile protein genes in response to pressure overload in the rat myocardium. I Clin Invest 89: 939-946, 1992.

30. Van Bilsen, M., L.H.E.H. Snoeckx, T. Arts, G.J. van der Vusse and R.S. Reneman. Performance of the isolated, ejecting heart: Effects of aortic impedance and exogenous substrates. Eur / Physiol (Pfligers Arch) 419: 7-12, 1991.

31. Walker, D., S. Kucukoglu, M.S. Marber, E. lliodromites, R. Ferrari and D.M. Yellon. Heat stress limits infarct size in the isolated perfused rat heart. Cardiovasc Res 27: 962-967, 1993.

32. Yellon, D.M., E. Pasini, A. Cargoni, M.S. Marber, D.S. Latchman and R. Ferrari. The protective role of heat stress in the ischemic and reperfused rabbit myocardium. / Mol Cell Cardiol 24: 895$907,1992$.

33. Yellon, D.M., E. Iliodromitis, D.S. Latchman, Winkle D. Van, J.M. Downey, F.M. Williams and T.J. Williams. Whole body heat stress fails to limit infarct size in the reperfused rabbit heart. Cardiovasc Res 26: 342-346, 1992. 
Chapter 5

BIPHASIC EFFECT OF HEAT STRESS PRETREATMENT
ON ISCHEMIC TOLERANCE OF ISOLATED RAT HEARTS 


\section{ABSTRACT}

It is known that $24 \mathrm{~h}$ after heat stress treatment postischemic recovery of cardiac performance is improved. In this study we investigated the extent of the time-lag of heat stress-induced protection against ischemia and reperfusion in more detail. To this end, post-ischemic functional recovery of isolated, ejecting rat hearts was investigated $0,0.5,3,6$ and 24 hours after heat stress $\left(42^{\circ} \mathrm{C}\right.$ for $\left.15 \mathrm{~min}\right)$. Hearts of only anesthetized rats served as controls. Recovery (\% of preischemic value) of cardiac output, left ventricular developed pressure, and positive and negative left ventricular $\mathrm{dPdt}_{\max }$ was studied during reperfusion after $45 \mathrm{~min}$ of global ischemia. The recovery of all hemodynamic variables was significantly lower in hearts isolated $30 \mathrm{~min}$ after heat stress than in control hearts. When the time-interval between heat treatment and the ischemia episode was prolonged, a gradual improvement of postischemic cardiac function was seen. Only $24 \mathrm{~h}$ after heat treatment significantly better functional recovery was observed compared to the anesthetized control group. mRNA levels of HSP72 and HSP73 were substantially elevated above baseline levels 3 hours after heat stress, with 7- and 2-fold increased values, respectively. These findings indicate that heat stress pretreatment exerts a biphasic effect on the resistance of isolated hearts against ischemia/reperfusioninduced damage, i.e. a rapid and transient negative effect followed by a positive effect, which becomes evident only $24 \mathrm{~h}$ following heat stress.

\section{INTRODUCTION}

In 1988, Currie and coworkers reported that $24 \mathrm{~h}$ after total body heat shock treatment the functional recovery of isolated hearts during reperfusion after 30 minutes of low flow ischemia improved substantially compared to that in nonheated controls [7]. In the following years it was shown that beside heat stress pretreatment, exposure of animals to endotoxin [3] or amphetamine [18] or submitting animals to heavy exercise [14] could induce cardioprotection 24 hours later. A common factor in all these interventions is the presence of a stress response in the heart and other tissues. This stress response consists of the induction and upregulation of a special set of proteins, the so-called stress proteins [20]. One of the most highly induced stress proteins upon heat shock or other stresses in the heart is a 72-kilodalton heat shock protein (HSP72) belonging to the HSP 70kDa family. Therefore, this protein has attracted much attention and studies suggested that the improved postischemic cardiac performance after heat shock may be related to the amount of HSP72 present in the heart at the time the organ was subjected to the ischemic insult $[13 ; 10 ; 16]$. Later, experiments using transgenic mice, overexpressing HSP72 in the heart, more definitely indicated that HSP72 was solely responsible for the observed cardioprotection [21].

HSP72 is almost undetectable in non-stressed tissues [8]. After heat shock the maximal concentration of HSP72 mRNA in the heart is reached at 1 to 2 hour(s) post heat shock. Thereafter, the mRNA level rapidly decays and is almost undetectable 6 hours after hyperthermic intervention [9]. The HSP72 protein is detectable at 1.5 hours after heat stress and accumulates to maximal levels 6 hours post heat stress [8][9]. This maximal protein level of HSP72 is sustained for 2 to 3 days and then gradually decreases being still detectable above baseline 8 days after hyperthermia [12]. 
It might be feasable to assume that since the HSP72 protein is already present within 1 to 2 hours following hyperthermia, heat shock-induced cardioprotection should also be present within this time-interval. However, almost all studies to date have investigated postischemic cardiac function only 24 hours after the initial heat stress the time at which cardioprotection is observed $[30 ; 26 ; 17]$. Only very limited information is available on the heat stress pretreatment induced effects within the first 24 hours after treatment. It seems that protection can also be observed shortly after the heat treatment [6][11]. For instance, in cultured mammalian cells thermotolerance ( $=$ the ability to withstand temperatures normally lethal to the cell) was observed within the first hours following hyperthermic pretreatment [6]. In a recent paper, it was shown that a 15 min hyperthermic perfusion (in vitro heat stress) of the isolated heart conferred immediate protection against an ischemic insult [19]. This early cardioprotection, however, was not observed in the in vivo heat-shocked heart [12].

The aim of the present study was to test whether heat stress preconditioning could confer cardioprotection against ischemia and reperfusion within the first 6 hours of recovery after the initial heat shock, since a) the HSP72 protein accumulates to maximal levels within 6 hours after hyperthermia, and b) in vitro heat stress pretreatment can confer immediate protection against ischemia-induced damage or a second heat stress [19][6]. The functional response of the heart towards heat stress was investigated after submission to a period of global ischemia at different time points within the first 24 hours following treatment. The level of the heat shock response was determined by the evaluation of the mRNA signal of both HSP72 and HSP73.

\section{MATERIALS AND METHODS}

\section{Animal preparation}

The experiments were performed on 14 weeks old male Lewis rats in body weight ranging from 300 to $350 \mathrm{~g}$. The animals were fed ad libitum (Diet SRM-A, Hope Farms), had free access to water and were kept under an artificial light cycle of $12 \mathrm{~h}$. All experiments were approved by the Care and Use Committee of the University of Limburg, Maastricht, the Netherlands.

\section{Heat-shock protocol}

The animals were anesthetized with Hypnorm ${ }^{\circledR}(0.01 \mathrm{mg}$ fentanyl $/ 100 \mathrm{~g}$ body weight plus $0.5 \mathrm{mg}$ fluanison $/ 100 \mathrm{~g}$ body weight s.c.) and placed on a temperaturecontrolled heating-pad until rectal temperature, which was continuously monitored rectally, reached $42^{\circ} \mathrm{C}$ (Lew ${ }_{H S}: n=45$ ). The animals were kept at this temperature for $15 \mathrm{~min}$. All animals survived the heat stress treatment and showed no signs of discomfort. Anesthetized animals followed the same protocol but were kept at $37^{\circ} \mathrm{C}$ (Lew An $\left.: n=20\right)$.

\section{Experimental groups for hemodynamic investigation}

The animals were killed by cervical dislocation either immediately after the hyperthermic treatment $(0 h ; n=4)$ or after $0.5(n=8), 3(n=6), 6(n=6)$ and 24 hour(s) $(n=7)$ of recovery from the hyperthermic treatment. Control hearts $(n=13)$ were only studied 24 hours after initial anesthesia, and not during the early phase, since based 
upon earlier observations function in the isolated heart is not depressed by anesthesia at any time following the application of the anesthetic.

\section{Heart preparation}

Following heat-shock or anesthesia the animals were lightly reanesthetized, if necessary, with Hypnorm ${ }^{\odot}(2 \mu \mathrm{g}$ fentanyl $/ 100 \mathrm{~g}$ body weight plus $0.1 \mathrm{mg}$ fluanison $1100 \mathrm{~g}$ body weight s.c.) and killed by cervical dislocation. Thereafter, the hearts were removed from the thorax and immediately immersed in an ice-cold Tyrode buffer solution, containing (in mmol/l): $\mathrm{NaCl}$ (130.0), $\mathrm{KCl}(5.6), \mathrm{CaCl}_{2}$ (2.2), $\mathrm{MgCl}_{2}(1.0)$, $\mathrm{NaH}_{2} \mathrm{PO}_{4}(1.2), \mathrm{NaHCO}_{3}(28.6)$ and $\mathrm{D}(+)$ glucose (11.1)

\section{Isolated heart perfusion}

The hearts were quickly trimmed from lung and fat tissue, weighed, and connected via the aorta to a perfusion apparatus installed in a thermostable cage $\left(37^{\circ} \mathrm{C}\right)$. Retrograde perfusion was immediately started at an afterload of $8 \mathrm{kPa}$. A second cannula was connected to the left atrium to allow antegrade perfusion of the hearts. The perfusion system has been described previously [23; 25]. The perfusion-buffer was continuously gassed with carbogen $\left(95 \% \mathrm{O}_{2}\right.$ and $5 \% \mathrm{CO}_{2} ; \mathrm{pO}_{2}>70 \mathrm{kPa}$; pH-range $\left.=7.32-7.45,37^{\circ} \mathrm{C}\right)$. Left atrial filling pressure was set at $1.3 \mathrm{kPa}$. Aortic pressure $\left(\mathrm{P}_{\mathrm{ao}}\right)$ was measured one $\mathrm{cm}$ above the aortic valve and left ventricular pressure through the apex of the heart with a small polyethylene catheter connected to an external pressure transducer (Spectramed, Bilthoven, the Netherlands). Left ventricular developed pressure (LVDP) was calculated as the difference between systolic and enddiastolic pressure. Left ventricular performance and relaxation were respectively estimated from the positive and negative maximal first derivative of left ventricular pressure $\left(+\mathrm{dP} / \mathrm{dt}_{\max }\right.$ and $\left.-\mathrm{dP} / \mathrm{dt} \max \right)$. The flow in the aortic cannula was measured with an extracorporeal flowprobe (diameter $3 \mathrm{~mm}$ ) connected to an electromagnetic flowmeter (Skalar, Delft, the Netherlands). Coronary flow (CF) was measured by timed collection of the coronary perfusate dripping from the heart. Cardiac output $(\mathrm{CO})$ was defined as the sum of aortic flow and coronary flow, and, by definition, was zero when the hearts were perfused in the retrograde way. All hemodynamic variables were fed into a computer allowing the on-line calculation and presentation of data [22]. The hearts were electrically paced $(5 \mathrm{~Hz})$ throughout the experiment, except during ischemia and the first $10 \mathrm{~min}$ of reperfusion.

\section{Perfusion protocol}

After a stabilization period of $10 \mathrm{~min}$, during which the hearts were perfused in the retrograde way, the left atrial cannula was opened and the hearts were allowed to eject. At the end of the $30 \mathrm{~min}$ preischemic period the hearts were subjected to 45 min of global ischemia by crossclamping the left atrial and aortic cannulas. Pacing was stopped. Hearts cooled down to about $32^{\circ} \mathrm{C}$ during the ischemic period. After ischemia, the hearts were reperfused during $15 \mathrm{~min}$ in the retrograde way and 30 min in the antegrade way, at identical diastolic $P_{\text {ao }}$ values as applied during the preischemic period. The maximum steady state values attained during the preischemic and postischemic antegrade perfusion periods were used for calculation of the percentage recovery of the hemodynamic variables. Coronary effluent samples were immediately frozen in liquid nitrogen and stored at $-80^{\circ} \mathrm{C}$ for biochemical analysis. The hearts within the various groups were studied at random. 


\section{Biochemical analysis}

Coronary effluent samples were monitored for the presence of creatine hinase (CK) a marker for irreversible cell damage. Enzyme activities were measured spectrophotometrically according to Bergmeyer and Bernt, using a Cobas Bio autoanalyzer [2].

\section{Production of cDNA of HSP72}

We obtained the total rat cDNA sequence of heat shock protein 72, a generous gift from Dr. Longo [15] in a Bluescript vector. This sequence was used as a PCRtemplate. $5^{\prime}$ and 3 ' primer oligonucleotides (28 mer) were designed to amplify a part of the hsp72 sequence near the $3^{\prime}$-terminus. The 5 ' primer contained a BamH1 restriction site whereas the $3^{\prime}$ primer was equipped with a HindIII restriction site. Conditions during PCR were as follows: $20 \mathrm{mM}$ Tris- $\mathrm{HCl}(\mathrm{pH}=8.2), 8 \mathrm{mM} \mathrm{MgCl}, 40$ $\mathrm{mg} / 1$ bovine serum albumin, $100 \mu \mathrm{M}$ dNTP each, $1 \mu \mathrm{M}$ oligonucleotides each, 200 ng DNA template, $2.5 \mathrm{U} / \mathrm{ml}$ pfu DNA polymerase, $1 \mathrm{~min} 95^{\circ} \mathrm{C}, 1 \mathrm{~min} 65^{\circ} \mathrm{C}, 1 \mathrm{~min}$ $72^{\circ} \mathrm{C}$, and 15 cycles. The PCR amplificated product was cut with BamH1 and HindIII and purified (Promega Miniprep Kit). The fragment was incubated with linearized pQE9 vector (cut with BamH1 and HindIII) in the presence of DNA ligase according to the manufacturers instruction (Life Technologies Inc, Gaitersburg, USA). Finally, the total ligation mixture was used to transform E. Coli strain DH5 $\alpha$, plated on ampicilline-containing agar and incubated overnight at $37^{\circ} \mathrm{C}$. Colonies were monitored for the presence of the HSP72 fragment with use of PCR and the oligonucleotides used to produce the fragment. The PCR product comprised a sequence from basepair 1663 to 1962 of the complete hsp72 cDNA resulting in a 300 bp fragment recognizing both inducible and constitutive forms of hsp70 mRNA.

\section{RNA isolation and northern blotting}

As indicated above, Lewis rats were subjected to only anesthesia $(n=7)$ or anesthesia followed by heat shock $(n=14)$. In addition, hearts of non-treated rats were used as controls (LewC $n=6$ ). After 3 or 24 hours following pretreatment the animals were lightly reanesthetized with Hypnorm ${ }^{\otimes}(2 \mu \mathrm{g}$ fentanyl $/ 100 \mathrm{~g}$ body weight plus 0.1 $\mathrm{mg}$ fluanison $/ 100 \mathrm{~g}$ body weight s.c.). After cervical dislocation the hearts were rapidly removed and immediately frozen in liquid nitrogen and stored at $-80^{\circ} \mathrm{C}$ until use. Total RNA was isolated according to Chomczynski and Sacchi [4] and the concentration was estimated by measurements of the optical density (OD) of the preparation at $260 \mathrm{~nm}(1 \mathrm{OD}=40 \mu \mathrm{g} \mathrm{RNA} / \mathrm{ml})$. The ratio between the readings at 260 and $280 \mathrm{~nm}\left(\mathrm{OD}_{260} / \mathrm{OD}_{280}\right)$ provided the estimate of the purity of the isolated RNA. Total RNA $(10 \mu \mathrm{g})$ was size-fractioned by agarose gel electrophoresis (1\% agarose containing $6.6 \%$ formaldehyde) and transferred to nitrocellulose (BA85, Schleicher and Schull, Einbeck, Germany) overnight by capillary action in $10 \times \mathrm{SSC}$ ( $1.5 \mathrm{M}$ $\mathrm{NaCl}, 0.17 \mathrm{M} \mathrm{Na}_{3} \mathrm{C}_{6} \mathrm{H}_{5} \mathrm{O}_{7}, \mathrm{pH}=7.0$ ). The RNA was fixed to the membrane by baking under vacuum at $80^{\circ} \mathrm{C}$ during $10 \mathrm{~min}$, followed by crosslinking under UV irradiation. The HSP72 and ribosomal 18S cDNA probes were labelled using the Random Primers Labelling System (Life Technologies) and ( $\alpha-32 \mathrm{P}) \mathrm{dCTP}$ to a specific activity of $0.5-1.0 \times 10^{9} \mathrm{cpm} / \mu \mathrm{g}$ probe. After prehybridization during 1 hour at $60^{\circ} \mathrm{C}$ in 6XSSC, 5XDenhardts, $0.5 \%$ SDS, and $100 \mu \mathrm{g} / \mathrm{ml}$ sonicated salmon sperm DNA, the membranes were incubated with the cDNA probes overnight at $60^{\circ} \mathrm{C}$. Before incubation the cDNA probes were denatured during $10 \mathrm{~min}$ at $95^{\circ} \mathrm{C}$ and added to the prehybridization mixture reaching a specific activity of $1.0 \times 10^{6} \mathrm{cpm} / \mu \mathrm{g}$ probe. Thereafter, the membranes were washed successively in 3 XSSC for $3 \mathrm{~min}$ at room 
temperature; 2 XSSC for $30 \mathrm{~min}$ at $42^{\circ} \mathrm{C}$; 2 XSSC plus $0.1 \%$ SDS for $30 \mathrm{~min}$ at room temperature; 0.1 XSSC plus $0.1 \%$ SDS for $30 \mathrm{~min}$ at $50-65^{\circ} \mathrm{C}$, and exposed to imaging screens for scanning and quantification (Phosphor Imager, Imagequant: Molecular Dynamics, Sunnyvale, CA, USA). After each hybridization, the residual cDNA was removed and rehybridized with the $18 \mathrm{~S} \mathrm{cDNA}$ probe. The levels of hsp72 and 73 mRNA were normalized to the 18S RNA levels to correct for total RNA loading variations.

\section{Statistics}

All values are expressed as mean values $\pm \mathrm{sd}$. Differences between heat-shocked and non-heated animals were evaluated for statistical significance using the MannWhitney $U$-test. Values of $p<0.05$ were considered to be statistically significant.

\section{RESULTS}

Preischemic hemodynamic performance: Table 1 shows that no differences were found in the preischemic hemodynamic variables between hearts of anesthetized and heat-shocked rats at different recovery times after heat shock.

Table 1: Preischemic hemodynamic variables in hearts of only anesthetized (control) and heat-shocked rats.

\begin{tabular}{|c|c|c|c|c|c|}
\hline & $\mathrm{n}$ & $\begin{array}{c}\mathrm{CO} \\
(\mathrm{ml} / \mathrm{min})\end{array}$ & $\begin{array}{l}\text { LVDP } \\
(\mathrm{kPa})\end{array}$ & $\begin{array}{c}+\mathrm{dP}^{\mathrm{P} / \mathrm{dt}_{\max }} \\
(\mathrm{kPa} / \mathrm{s})\end{array}$ & $\begin{array}{c}-\mathrm{dP}^{-\mathrm{dt}_{\max }} \\
(\mathrm{kPa} / \mathrm{s})\end{array}$ \\
\hline $24 \mathrm{~h}$ after An & 13 & $94 \pm 9$ & $10.9 \pm 0.5$ & $724 \pm 66$ & $-408 \pm 68$ \\
\hline $0 \mathrm{~h}$ after $\mathrm{HS}$ & 4 & $99 \pm 3$ & $11.7 \pm 0.5$ & $791 \pm 66$ & $-413 \pm 92$ \\
\hline $0.5 \mathrm{~h}$ after $\mathrm{HS}$ & 8 & $94 \pm 8$ & $11.4+0.5$ & $734 \pm 68$ & $-389 \pm 51$ \\
\hline $3 \mathrm{~h}$ after $\mathrm{HS}$ & 6 & $86 \pm 6$ & $10.6 \pm 0.5$ & $779 \pm 96$ & $-376 \pm 70$ \\
\hline $6 \mathrm{~h}$ alter $\mathrm{HS}$ & 6 & $98 \pm 6$ & $11.2 \pm 0.6$ & $760 \pm 80$ & $-422+29$ \\
\hline $24 \mathrm{~h}$ after $\mathrm{HS}$ & 7 & $95 \pm 7$ & $10.9 \pm 0.8$ & $782 \pm 73$ & $-423 \pm 18$ \\
\hline
\end{tabular}

Data are mean values $\pm \mathrm{sd}$. CO refers to cardiac output; LVDP, left ventricular developed pressure; $+/-\mathrm{dP} / \mathrm{dt}_{\max }$, positive respectively negative maximal first derivative of left ventricular pressure; $H S$ and An refer to heat shock and anesthesia, respectively.

However, when the time-interval between heat stress and isolated heart perfusion was between 0.5 and 24 hours significantly higher coronary flow values were found compared to control hearts (Table 2).

Postischemic hemodynamic performance: Only when the time-interval between heat stress pretreatment and isolated heart perfusion was 24 hours, significantly higher postischemic recovery of all hemodynamic variables were found compared to the control group (Table 3). However, in those hearts studied $0.5 \mathrm{~h}$ after heat shock the opposite was observed. In these hearts recovery of $\mathrm{CO}$ reached $26 \pm 25 \%$, LVDP $47 \pm 40 \%$, $+\mathrm{dP} / \mathrm{dt}_{\max } 41 \pm 35 \%$, and $-\mathrm{dP} / \mathrm{dt}_{\max } 41 \pm 38 \%$ of the preischemic values, respectively. These values were significantly lower compared to the recovery values in control hearts where CO reached $54 \pm 11 \%$, LVDP $81 \pm 5 \%,+\mathrm{dP} / \mathrm{dt}_{\max } 69 \pm 10 \%$, and $-\mathrm{dP} / \mathrm{dt}_{\max } 75 \pm 13 \%$ of the preischemic values, respectively (Table 3 ). Postischemic 
Table 2: Preischemic and postischemic coronary flow values in hearts of only anesthetized (control) and heat-shocked rats.

\begin{tabular}{|c|c|c|c|}
\hline & $\mathrm{n}$ & $\begin{array}{c}\text { Preischemic } \\
\text { CF } \\
\text { (ml/min.g) }\end{array}$ & $\begin{array}{c}\text { Postischemic } \\
\text { CF } \\
\text { (ml/min.g) }\end{array}$ \\
\hline $\begin{array}{l}24 \mathrm{~h} \text { after An } \\
0 \mathrm{~h} \text { after HS }\end{array}$ & $\begin{array}{c}13 \\
4\end{array}$ & $\begin{array}{l}11.9 \pm 0.9 \\
12.3 \pm 0.6\end{array}$ & $\begin{array}{l}9.5 \pm 1.5 \\
9.1 \pm 1.7\end{array}$ \\
\hline $0.5 \mathrm{~h}$ after HS & 8 & $13.5 \pm 1.0^{*}$ & $8.9 \pm 2.9$ \\
\hline $3 \mathrm{~h}$ after HS & 6 & $13.7 \pm 0.9^{*}$ & $11.6 \pm 1.3^{*}$ \\
\hline $6 \mathrm{~h}$ after HS & 6 & $14.0 \pm 1.8^{*}$ & $10.4 \pm 1.0$ \\
\hline $24 \mathrm{~h}$ after HS & 7 & $13.9 \pm 0.9^{*}$ & $12.8 \pm 1.9^{*}$ \\
\hline
\end{tabular}

coronary flow was significantly increased in hearts removed either 3 or 24 hours after the heat shock pretreatment but not in the other groups (Table 2). With the exception of the group tested $0.5 \mathrm{~h}$ following heat stress, all heat-stressed hearts regained regular mechanical function within the $45 \mathrm{~min}$ of reperfusion. Within the group investigated $0.5 \mathrm{~h}$ after heat stress, 3 out of 8 hearts did not show any recovery of mechanical function.

Table 3: Maximal percentage recovery of hemodynamic variables in hearts of anesthetized (control) and heat-shocked rats.

\begin{tabular}{|c|c|c|c|c|c|}
\hline & $\mathrm{n}$ & $\begin{array}{c}\mathrm{CO} \\
\%\end{array}$ & $\begin{array}{c}\text { LVDP } \\
\%\end{array}$ & $+\underset{\%}{+d P / d t_{\max }}$ & $-\mathrm{dP}_{\%} \mathrm{dt}_{\max }$ \\
\hline $24 \mathrm{~h}$ after $\mathrm{An}$ & 13 & $54 \pm 11$ & $81 \pm 5$ & $69 \pm 10$ & $75 \pm 13$ \\
\hline $0 \mathrm{~h}$ after $\mathrm{HS}$ & 4 & $59 \pm 18$ & $79 \pm 10$ & $70 \pm 12$ & $73 \pm 16$ \\
\hline $\begin{array}{l}0.5 \mathrm{~h} \text { after HS } \\
3 \mathrm{~h} \text { after HS } \\
6 \mathrm{~h} \text { after HS }\end{array}$ & $\begin{array}{l}8 \\
6 \\
6\end{array}$ & $\begin{array}{c}26 \pm 25^{*} \\
63 \pm 14 \\
66 \pm 14\end{array}$ & $\begin{array}{r}47 \pm 40^{*} \\
81 \pm 9 \\
85 \pm 6\end{array}$ & $\begin{array}{c}41 \pm 35^{*} \\
68 \pm 14 \\
77 \pm 8\end{array}$ & $\begin{array}{c}44 \pm 38^{*} \\
81 \pm 11 \\
81 \pm 10\end{array}$ \\
\hline $24 \mathrm{~h}$ after HS & 7 & $74 \pm 8^{*}$ & $91 \pm 2^{*}$ & $79 \pm 2^{*}$ & $86 \pm 4^{*}$ \\
\hline
\end{tabular}

\section{Enzyme release}

The significantly improved functional recovery observed in hearts with a recovery time of $24 \mathrm{~h}$ after heat shock was associated with a $38 \%$ reduction in the release of 
creatine kinase, compared to the values in control hearts $(\mathrm{p}<0.05)$. In all other heatshocked groups no differences compared to the control group could be detected.

\section{HSP mRNA expression}

mRNA transcripts for HSP72 were almost undetectable in the myocardium of control rats or in hearts of anesthetized rats either 3 or 24 hours following the application of the anesthetic, but were abundant at 3 hours following heat stress (Figure 1a and b). In the investigated hearts the transcripts of HSP72 were on the average 7 times higher compared to the transcripts after 3 hour anesthesia. The mRNA transcripts for HSP72 were slightly elevated 24 hours after the heat stress pretreatment. In contrast, the mRNA transcripts for the cognate HSP73 were clearly present under all conditions and were two times upregulated at 3 hours after heat shock. The level of the HSP73 transcript returned to control values 24 hours following heat stress.

\section{DISCUSSION}

The findings in the present study indicate that heat stress pretreatment does not lead to protection of the heart against ischemia and reperfusion-related damage within the first 6 hours following application of the stress, as evidenced by the lack of improvement of postischemic functional recovery and the reduction of the loss of intracellular enzymes compared to the non-pretreated control heart. Moreover, within a short period following heat stress, the heart seems to be more vulnerable to an ischemic insult. This negative response is transient and is not due to a generalised hemodynamic dysfunction since the preischemic hemodynamic function is comparable to that in the non-pretreated control heart. The results also show that 24 hours following hyperthermic pretreatment the resistance towards ischemia and reperfusion-related damage is significantly increased compared to the non-pretreated heart, as evidenced by an improved postischemic functional recovery and a reduction of tissue injury, confirming data earlier obtained by other investigators $[7 ; 30]$.

It has been suggested that the increased resistance of the heat-shocked heart towards an ischemic insult can be correlated with the tissue content of the inducible HSP72 protein $[10 ; 16 ; 21]$. Although in the present study the cardiac protein levels of HSP72 were not determined, the expression levels of the messenger RNA signal were investigated 3 and 24 hours following treatment. The significantly higher HSP72 expression levels at 3 hours after heating indicate that the time-frame of induction of the mRNA signal and thus also of the corresponding protein was comparable to that reported by other investigators $[9 ; 19]$. Our findings thus suggest that the HSP72 protein had accumulated to substantial levels at 6 hours following heat treatment.

In view of the above mentioned relationship between the amount of induced HSP72 protein and the level of cardioprotection, how then it can be explained that cardioprotection is completely absent at 3 and 6 hours following treatment? The explanation for this discrepancy could be found in the intracellular localisation pattern of the HSP72 protein during the first 24 hours following heat stress. It is known that immediately following synthesis, the HSP72 protein translocates to the nucleus, more specifically to the nucleolar region $[24 ; 28]$. It has been suggested that within the nucleolus the protein binds to preribosomal complexes [29] and that 
(A)
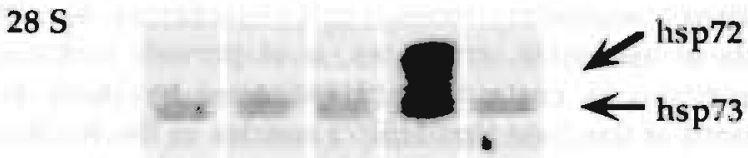

$18 \mathrm{~S}$

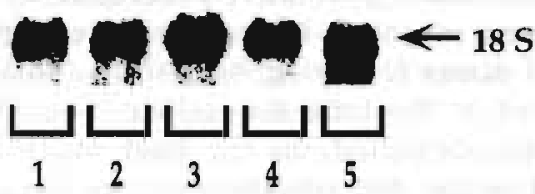

(B)

Relative units/18 S

0,3
0,2
0,1

(6)

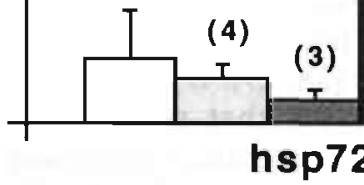

(9)

(5)

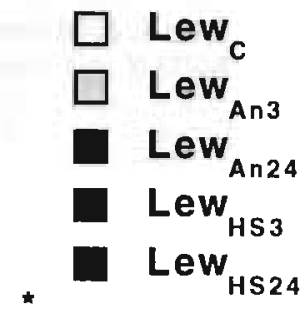

(9)
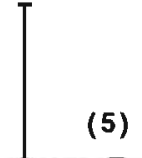

(6)

(4)

(5)
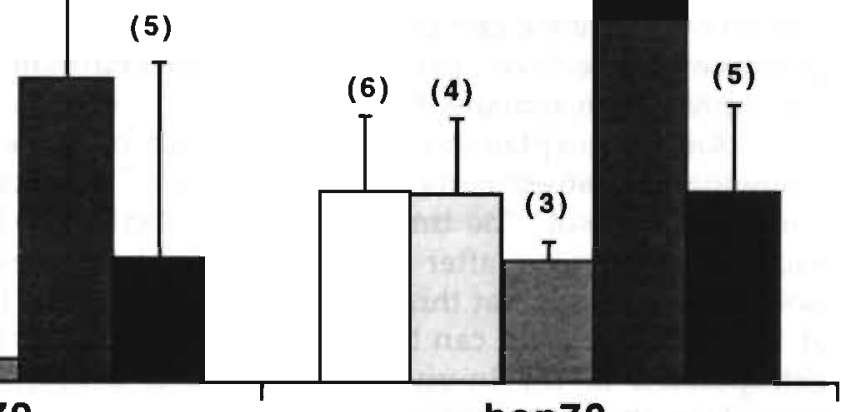

hsp73

Figure 1: (A) Representative Northern blot obtained from rat cardiac tissue showing the presence of the inducible (hsp72) and constitutive (hsp73) form of heat shock proteins. The 18 $\mathrm{S}$ signal is presented to indicate comparable loading conditions. (B) Quantitative data determined by phosphor imaging technique of hsp72 and hsp73 mRNA expression. Lane 1: non-anesthetized control heart (LewC), lane 2 and 3: anesthetized controls 3 (Lew An3) and 24 hours (Lew An24) after application of the anesthetic, respectively, lane 4 and 5: heat-stressed hearts 3 (LewHS3) and 24 hours (LewHS24) after application of heat stress, respectively. Data are presented as meantsd.": significantly different from the data in the corresponding nonanesthetized, and anesthetized control groups. Number in brackets refer to number of hearts. 
HSP72 prevents the precipitation of these complexes, eventually enabling the recovery of ribonucleic protein translational activity in a later phase. Whether the protection against a secondary stress, such as ischemia, is related to the interaction of HSP72 with these nucleolar structures, is at present unknown. Our results suggest that this interaction is certainly not essential by itself since protection against ischemia is absent at the time that HSP72 resides in the nucleolus, i.e. at 3 and 6 hours after heat stress. It can not be excluded however that this interaction is essential for the initiation of secondary, protective processes. In that case, it can be hypothesised that certain proteins essential for cardioprotection, are preferentially synthesised during the first 24 hours following heat stress, and that increased amounts of these proteins are present at the time the ischemic insult is applied. Until now, no such proteins have been identified. In the past much attention has been focussed on enzymes involved in the detoxification of free oxygen radicals, since we and others found that the activity of catalase and/or superoxide dismutase was increased in heatshocked hearts $[5 ; 7 ; 18 ; 30]$. However, in the case of catalase

Table 4: Total preischemic (30 min) and postischemic (45 min) loss of creatine kinase (CK) from isolated hearts of only anesthetized (control) and heat-shocked rat hearts.

\begin{tabular}{|c|c|c|c|c|c|c|}
\hline Group & $\begin{array}{c}24 h \text { after An } \\
(n=13)\end{array}$ & $\begin{array}{c}\text { Oh after HS } \\
(n=4)\end{array}$ & $\begin{array}{c}0.5 \mathrm{~h} \text { after } \mathrm{H} \\
(\mathrm{n}=8)\end{array}$ & $\begin{array}{c}\text { 3h after HS } \\
(n=6)\end{array}$ & $\begin{array}{c}\text { 6h after HS } \\
(n=6)\end{array}$ & $\begin{array}{c}24 \mathrm{~h} \text { after HS } \\
(\mathrm{n}=7)\end{array}$ \\
\hline \multicolumn{7}{|c|}{$C K(U / g w w)$} \\
\hline pre & $3.3 \pm 1.6$ & $4.8 \pm 2.2$ & $6.5 \pm 4.5$ & $6.1 \pm 3.7$ & $4.5 \pm 1.2$ & $6.5 \pm 3.1$ \\
\hline post & $27.1 \pm 13.4$ & $25.3 \pm 9.6$ & $32.7 \pm 13.4$ & $27.2 \pm 10.1$ & $30.5 \pm 13.1$ & $16.7 \pm 5.0^{*}$ \\
\hline
\end{tabular}

Data are mean values $\pm \mathrm{sd}$. U/g $w w=$ units/gram wet heart tissue weight; HS and An refer to heat shock and anesthesia, respectively. " significantly different from corresponding control group values.

the increased activity is not due to an increased transcriptional rate of the catalase gene since mRNA levels have been shown to be not increased [9]. So, until no conclusive evidence can be presented on increased transcription and translation of putative protective proteins, this mechanism of heat shock- mediated cardioprotection remains hypothetical.

Another explanation for the absence of protection within the first 6 hours following heat stress is the fact that the HSP72 protein resides in the nucleolus and not in the cytosol. The time required for HSP72 to translocate from the nucleolus back into the cytosol after heat stress is not known exactly, but it has been found in isolated fibroblasts that this process occupies about 8 hours [29]. After 24 hours, most of the HSP72 protein can be localised in the cytosol $[28 ; 29]$. If these results can be extrapolated to the in-vivo situation, it is conceivable that protection against a secondary stress such as ischemia is mediated by an essential interaction between HSP72 and cytosolic proteins which only can take place approximately 24 hours after the heat treatment. In this view the limitation of the loss of intracellular enzymes following an ischemic insult, observed 24 hours after heat treatment, could be related to the interaction of HSP72 with certain membrane proteins or other proteins which have a membrane-stabilising effect.

As we found earlier [5], in the present study we observed increased coronary flow levels both during the preischemic and postischemic periods 24 hours after the heat treatment. We do not have conclusive evidence that the observed 
cardioprotection is related to the increased perfusion of the myocardium, but the latter phenomenon seems to be generalised in hearts in which the expression of HSP72 is enhanced. The phenomenon is probably not related to the heat shock: procedure itself, because it is also observed in hearts of transgenic mice, in which HSP72 is constitutively overexpressed [21]. Our results indicate that the enhancement of coronary flow is an early phenomenon since it can already be observed preischemically within 30 minutes following heat treatment. The fact that coronary flow is also significantly enhanced during the postischemic period 3 hours after the heat treatment, the time at which improvement of postischemic function is absent, makes it unlikely that the enhancement of coronary flow is a crucial candidate for the heat shock-mediated cardioprotection.

The hemodynamic results obtained in hearts isolated $30 \mathrm{~min}$ following pretreatment indicate that heat can also have adverse effects on the performance of the heart after an ischemic insult. Indeed, although the preischemic function in these hearts is completely comparable to that of control hearts, the postischemic recovery is significantly depressed compared to that in all other groups. This phenomenon has, to the best of our knowledge, not been described before. It is known that the heat shock procedure immediately leads to the arrest of normal transcription and protein translation processes [27], and that existing proteins can precipitate due to heat denaturation [1]. It is therefore possible that this imbalance between protein synthesis and degradation labilises the myocardial cells and temporarily provokes an increased vulnerability to a secondary stress. The occurrence of this negative phenomenon takes some time because it was not observed in hearts subjected to ischemia immediately following heat shock. Otherwise, in these hearts no improvement of postischemic function could be observed which contrasts with the findings of McCully and colleagues [19] who recently showed that a brief hyperthermic perfusion of isolated hearts led to immediate cardioprotection against ischemia. An explanation for this discrepancy is not immediately at hand, but could be related to the differences in experimental protocol. Indeed it was already shown before that in rat hearts, isolated from rats heat shocked in-vivo, cardioprotection was also absent [12].

In conclusion, the findings of the present study indicate that the heart can not be protected against an ischemic insult within a certain time frame following heat treatment, even when the expression of HSP72 is maximal. To elucidate the discrepancy between the time of presence of the inducible HSP72 protein and the occurrence of cardioprotection, more detailed studies on the subcellular localisation of the protein and its interaction with other proteins are needed.

\section{LITERATURE}

1. Ananthan, J., A .Goldberg and R. Voellmy. Abnormal proteins serve as eukaryotic stress signals and trigger the activation of heat shock genes. Science 232: 522-524, 1986.

2. Bergmeyer, H. and E. Bernt. UV assay for creatine kinase. In: Methods of Enzymology, Weinheim Verlag Chemie GmbH, pp. 784-788, 1974.

3. Brown, J., M. Grosso, L. Terada, G. Whitman, A. Banerjee, C. White, A. Harken and J. Repine. Endotoxin pretreatment increases endogenous myocardial catalase activity and decreases reperfusion injury of isolated rat hearts. Proc Natl Acad Sci USA 86: 2516-2520, 1989.

4. Chomczynski, P. and N. Sacchi. Single-step method of RNA isolation by acid guanidinium thiocyanate-phenol-chloroform extraction. Anal Biochem 162: 156-159, 1987. 
5. Cornelussen, R., W. Spiering, J.H.G. Webers, L.G.A. de Bruin, R.S. Reneman, G.J. van der Vusse and L.H.E.H. Snoeckx. Heat shock improves the ischemic tolerance of the hypertrophied rat heart. Am J Physiol 267: H1941-H1947, 1994.

6. Crête, P. and J. Landry. Induction of HSP27 phosphorylation and thermoresistence in chinese hamster cells by arsenite, cycloheximide, A23187, and EGTA. Radiat Res 121: 320-327, 1990.

7. Currie, R.W., M. Karmazyn, M. Kloc and K. Mailer. Heat-shock response is associated with enhanced post-ischemic recovery. Circ Res 63: 543-549, 1988.

8. Currie, R.W. and F. White. Characterization of the synthesis and accumulation of a 71kilodalton protein induced in rat tissues after hyperthermia. Can J Biochem Cell Biol 61: 438-446, 1983.

9. Currie, R.W. and R.M. Tanguay. Analysis of RNA for transcripts for catalase and SP71 in rat hearts after in vivo hyperthermia. Biochem Cell Biol 69: 375-82, 1991.

10. Hutter, M.M., R.E. Sievers, V. Barbosa and C.L. Wolfe. Heat-shock protein induction in rat hearts. A direct correlation between the amount of heat-shock protein induced and the degree of myocardial protection. Circulation 89: 355-60, 1994.

11. Kampinga, $\mathrm{H}$. Thermotolerance in mammalian cells. Protein denaturation and aggregation, and stress proteins. J Cell Sci 104: 11-17, 1993.

12. Karmazyn, M., K. Mailer and R.W. Currie. Acquisition and decay of heat-shockenhanced postischemic ventricular recovery. Am J Physiol 259: H424-H431, 1990.

13. Li, G. and Z. Werb. Correlation between synthesis of heat shock proteins and development of thermotolerance in Chinese hamster fibroblasts. Proc Natl Acad Sci USA 79: 3516-3520, 1982.

14. Locke, M., R. Tanguay, R. Klabunde and C. Ianuzzo. Enhanced postischemic myocardial recovery following exercise induction of HSP72. Am J Physiol 269: H320-H325, 1995.

15. Longo, F., S .Wang, P. Narasimhan, J. Zhang, J. Chen, S. Massa and F. Sharp. cDNA cloning and expression of stress-inducible rat hsp70 in normal and injured rat brain. J Neturosci Res 36: 325-335, 1993.

16. Marber, M.S., R. Mestril, S-H. Chi, M. Sayen, D.M. Yellon and W. Dillmann. Overexpression of the rat inducible 70-kD heat stress protein in a transgenic mouse increases the resistance of the heart to ischemic injury. J Clin Invest 95: 1446-1456, 1995.

17. Marber, M.S., J.M. Walker, D.S. Latchman and D.M. Yellon. Myocardial protection after whole body heat stress in the rabbit is dependent on metabolic substrate and is related to the amount of the inducible 70-kD heat stress protein. / Clin Invest 93: 1087-1094, 1994.

18. Maulik, N., Z. Wei, X. Liu, R. Engelman, J. Rousou and D. Das. Improved postischemic ventricular functional recovery by amphetamine is linked with its ability to induce heat shock. Mol Cell Biochem 137: 17-24, 1994.

19. McCully, J., M. Lotz, I. Krukenkamp and S. Levitsky. A brief period of retrograde hyperthermic perfusion enhances myocardial protection from global ischemia: association with accumulation of hsp70 mRNA and protein. / Mol Cell Cardiol 28: 231-241, 1996.

20. Mestril, R. and W. Dillmann. Heat shock proteins and protection against myocardial ischemia. $J$ Mol Cell Cardiol 27: 45-52, 1995.

21. Plumier, J.C.L., B. Ross, R .W.Currie, C. Angelidis, H. Kazlaris, G. Kollias and G. Pagoulatos. Transgenic mice expressing the human heat shock protein 70 have improved post-ischemic myocardial recovery. I Clin lnvest 95: 1854-1860, 1995.

22. Snoeckx, L.H.E.H., J. Schrijen, M. van Bilsen, W. Lammers, T. van der Nagel, G.J. van der Vusse and R.S. Reneman. A microcomputer system for hemodynamic measurements in isolated, working rat hearts. Comp Biol Med 4: 301-309, 1986.

23. Snoeckx, L.H.E.H., G.J. van der Vusse, F. van der Veen, W. Coumans and R.S. Reneman. Recovery of hypertrophied rat hearts after global ischemia and reperfusion at different perfusion pressures. Pflugers Arch 413: 303-312, 1989.

24. Snoeckx, L.H.E.H., F. Contard, JL. Samuel, F. Marotte and L. Rappaport. Expression and cellular distribution of heat-shock and nuclear oncogene proteins in rat hearts. Am / Physiol H1443-H1451, 1991.

25. Van Bilsen, M., L.H.E.H. Snoeckx, T. Arts, G.J. van der Vusse and R.S. Reneman. Performance of the isolated, ejecting heart: Effects of aortic impedance and exogenous substrates. Pflugers Arch 419: 7-12, 1991.

26. Walker, D.S., S. Kucukoglu, M.S. Marber, E. lliodromites, R. Ferrari and D.M. Yellon. Heat stress limits infarct size in the isolated perfused rat heart. Cardiovasc Res 27: 962-967, 1993. 
27. Welch, WJ.. The mammmalian stress response: cell physiology and biochemistry of stress proteins. In: Stress in Biology and medicine. Eds. RI. Morimoto, A. Tissières, C. Georgopoulos, Cold Spring Harbor Laboratory Press,. pp 223-278, 1990.

28. Welch, W.J. and J. Feramisco. Nuclear and neonuclear localization of the 72.000 dalton heatshock protein in heat-shocked mammalian cells. J Biol Chem 259: 4501-4513, 1984.

29. Welch, W.J. and J. Suhan. Cellular and biochemical events in mammalian cells during and after recovery from physiological stress. J Cell Biol 103: 2035-2052, 1986.

30. Yellon, D.M., E. Pasini, A. Cargoni, M.S. Marber, D.S. Latchman and R. Ferrari. The protective role of heat stress in the ischemic and reperfused rabbit myocardium. I Mol Cell Cardiol 24: 895$907,1992$. 


\section{Chapter 6}

\section{INABILITY OF THE HEAT-SHOCKED HEART TO ADJUST ITS PREISCHEMIC AND POSTISCHEMIC PERFORMANCE TO VARIABLE LOADING CONDITIONS}

This study was published as "Inability of the heat-shocked heart to adjust its preischemic and postischemic cardiac performance to variable loading conditions" by R. Cornelussen, G.J. van der Vusse, R.S. Reneman and L.H.E.H. Snoeckx in J. Mol. Cell. Cardiol. 28: 291-298, 1996 


\section{ABSTRACT}

The aim of the present study was to investigate whether the preischemic and postischemic hemodynamic function of the heat-shocked rat heart is affected by changes in afterload and extracellular calcium concentrations $\left(\left[\mathrm{Ca}^{2+}\right]_{e}\right)$. Experiments were performed on isolated, ejecting Lewis rat hearts 24 hours after in vivo heat shock. (Lew $w_{H S}$ ) or anesthesia alone (LewC). In vitro hearts were subjected to $60 \mathrm{~min}$ normoxic perfusion, $45 \mathrm{~min}$ global ischemia, and $60 \mathrm{~min}$ of reperfusion. Preischemic and postischemic left ventricular performance was evaluated at $\left[\mathrm{Ca}^{2+}\right]_{\mathrm{e}}$ ranging between 0.65 and $3.0 \mathrm{mM}$ at afterloads of $8.0 \mathrm{kPa}$ and $16.0 \mathrm{kPa}$. At $8.0 \mathrm{kPa}$, preischemic function was comparable in LewHS and LewC at $\left[\mathrm{Ca}^{2+}\right]_{e}$ equal to or above $2.25 \mathrm{mM}$. At lower $\left[\mathrm{Ca}^{2+}\right]_{e}$, i.e., 0.65 and $1.25 \mathrm{mM}$, cardiac output (CO) was significantly lower in LewHS than in LewC hearts. At $16.0 \mathrm{kPa}$ significantly lower $\mathrm{CO}$ values were found in Lew $\mathrm{HS}$ than Lew $\mathrm{C}$ hearts at all $\left[\mathrm{Ca}^{2+}\right]_{\mathrm{e}}$ levels. During postischemic reperfusion under basal conditions $\left(8.0 \mathrm{kPa} ;\left[\mathrm{Ca}^{2+}\right]_{\mathrm{e}}=2.25 \mathrm{mM}\right)$ a significantly better recovery was observed in Lew ${ }_{H S}$ than LewC hearts, persisting at $\left[\mathrm{Ca}^{2+}\right]_{e}$ equal to $1.25 \mathrm{mM}$. However, either by lowering $\left[\mathrm{Ca}^{2+}\right]_{e}$ to $0.65 \mathrm{mM}$ or increasing afterload to $16.0 \mathrm{kPa}$ (at all $\left[\mathrm{Ca}^{2+}\right]_{e}$ ), heat shock-associated improvement of postischemic performance disappeared. In conclusion, preischemic left ventricular performance of the isolated heat-shocked heart is depressed when it performs at low $\left[\mathrm{Ca}^{2+}\right]_{\mathrm{e}}$ or against a relatively high afterload. The heat shock-mediated improvement of postischemic function is only present at relatively low afterload levels in combination with normal extracellular calcium concentrations.

\section{INTRODUCTION}

Evidence is accumulating that heat shock pretreatment offers cardioprotection against a subsequent period of ischemia $[7,29]$ and limits myocardial infarction $[8,10$, 29]. This phenomenon is not only observed in the normal heart but can also be seen in the hypertrophied rat heart [5]. The mechanism behind the heat shock-mediated cardioprotection has not yet been fully elucidated. The intracellular presence of inducible heat shock proteins (HSPs) seems to be essential. Indeed, a strong correlation was found between the level of the $72 \mathrm{kDa}$ HSP (HSP72) and improved salvage of the myocardium in intact rat hearts [15] and in cardiac papillary muscles from the rabbit [18]. Furthermore, indirect induction of HSPs by other stimuli, such as endotoxin or amphetamine exposure, also confers cardiac protection against a subsequent ischemic insult [3, 19]. Finally, enhanced intracellular presence of HSI72, as obtained in isolated, HSP72-transfected cells, offers protection against various types of cellular stress, like hyperthermia, anoxia or metabolic stress [14, 22]. Although the presence of HSP72 seems to be crucial, it is unclear how the ultimate protection is mediated by this protein. It has been suggested that HSPs associate with proteins, which denature as a consequence of sustained ischemia [21]. HSP-binding might prevent rapid intracellular precipitation of the affected protein. As such, they provide a better efficiency of metabolic processes and enhanced integrity of cellular structures.

Postischemic reperfusion of cardiac tissue is characterized by electrical instability and loss of cellular membrane integrity, leading to irreversible loss of cellular constituents and to abnormal influx of ions, such as sodium and calcium. These alterations are most likely associated with contracture and depressed 
contractile function [20]. Heat shock mediated cardioprotection during postischemic reperfusion is thought to be associated with less calcium influx, resulting in a better preserved ultrastructure of and a decreased calcium accumulation in the mitochondria of cardiomyocytes [7, 29]. Moreover, experimental findings indicate that heat-shocked hearts showed a decreased vulnerability to a subsequent submaximal calcium paradox [17]. Besides, it cannot be excluded that the prominent coronary vasodilatation in heat-shocked hearts, as found by our group, is also calcium-related [6].

As calcium likely plays a crucial role in ischemia/reperfusion induced cardiac damage on the one hand [20] and in the mechanism underlying the effects of heat shock on cardiac function on the other, in the the present study the role of $\mathrm{Ca}^{2+}$ in myocardial protection against ischemia of heat-shocked and control hearts was investigated. To this end these hearts were exposed to various extracellular calcium concentrations $\left(\left[\mathrm{Ca}^{2+}\right]_{e}\right)$ before and after a period of ischemia. The $\mathrm{Ca}^{2+}$-challenge was applied at normal $(8.0 \mathrm{kPa})$ and increased $(16.0 \mathrm{kPa})$ left ventricular afterload.

\section{MATERIALS AND METHODS}

\section{Animal preparation}

All experiments were performed on 14 week-old male Lewis rats. The experiments were approved by the Institutional Animal Care and Use Committee of the University of Limburg. The animals were fed ad libitum and had free access to food (Hope farms, Woerden, the Netherlands) and water.

\section{Heat shock protocol}

The animals were anesthetized with Hypnorm ${ }^{(3)}(0.01 \mathrm{mg} / 100 \mathrm{mg}$ body weight fentanyl plus $0.5 \mathrm{mg} / 100 \mathrm{mg}$ body weight fluanisone s.c.). Rectal temperature was raised to $42^{\circ} \mathrm{C}$ by placing the animal on a temperature-controlled heating pad and was kept at that level for 15 min (LewHS; $n=6$ ). Non-heated control animals (Lew $\mathrm{n}=6$ ) were anesthetized only.

\section{Isolated heart perfusion}

Twenty four hours after heat shock pretreatment the rats were reanesthetized with Hypnorm $®$ and killed by cervical dislocation. The hearts were rapidly excised, cannulated and perfused according to the isolated ejecting heart model, as described before $[24,26]$. Initially the hearts were perfused for $10 \mathrm{~min}$ in a retrograde fashion (Langendorff mode). The perfusion buffer was continuously gassed with carbogen (95 \% $\mathrm{O}_{2}$ and $5 \% \mathrm{CO}_{2} ; \mathrm{pO}_{2}>70 \mathrm{kPa}$; pH-range: $7.32-7.45$, temperature: $37{ }^{\circ} \mathrm{C}$ ) and consisted of (in mmol/l): $\mathrm{NaCl}(130.0), \mathrm{KCl}(5.6), \mathrm{CaCl}_{2}$ (2.25), $\mathrm{MgCl}_{2}$ (1.0), $\mathrm{NaH}_{2} \mathrm{PO}_{4}$ (1.2), $\mathrm{NaHCO}_{3}(28.6)$ and $\mathrm{D}(+)$ glucose (11.1). The left atrium was connected to a second cannula so that the hearts were allowed to eject fluid through the aortic valve (antegrade perfusion). Left atrial filling pressure was set at $1.3 \mathrm{kPa}$. Aortic pressure was measured one $\mathrm{cm}$ above the aortic valve and left ventricular pressure (LVP) through the apex of the heart with a small polyethylene catheter connected to an external pressure transducer (Spectramed, Bilthoven, the Netherlands). Left ventricular developed pressure (LVDP) was calculated as the difference between systolic and end-diastolic pressure. Left ventricular systolic performance and diastolic relaxation were estimated from the positive and negative maximal first derivative of left ventricular pressure (positive $\mathrm{dP} / \mathrm{dt}_{\max }$ and negative $\mathrm{dP} / \mathrm{dt}_{\max }$ ), 
respectively. Mean flow in the aortic cannula (aortic flow) was measured with an extracorporeal flowprobe $(\varnothing: 3 \mathrm{~mm})$ connected to an electromagnetic flowmeter (type 601, Skalar, Delft, the Netherlands). Coronary flow (CF) was measured by timed collection of the coronary perfusate dripping from the heart. Cardiac output (CO) was defined as the sum of aortic flow and coronary flow, and, by definition, was zero when the hearts were perfused in the retrograde way. All hemodynamic variables were fed into a computer allowing the on-line calculation and presentation of data [23].

\section{Perfusion protocol}

After an initial retrograde perfusion period of $10 \mathrm{~min}$, both Lew $\mathrm{HS}(\mathrm{n}=6)$ and LewC $(n=6)$ hearts were allowed to eject for $20 \mathrm{~min}$ (antegrade perfusion) at a diastolic aortic pressure (afterload) of $8.0 \mathrm{kPa}$ and $\left[\mathrm{Ca}^{2+}\right]_{\mathrm{e}}$ equal to $2.25 \mathrm{mM}$. As shown in Figure 1 during the following $25 \mathrm{~min}$, left ventricular performance was challenged by changing $\left[\mathrm{Ca}^{2+}\right]_{e}$ in steps between 0.65 and $3.0 \mathrm{mM}$ and by switching the afterload level from 8.0 to $16.0 \mathrm{kPa}$ at each $\mathrm{Ca}^{2+}$ concentration. Hemodynamic variables were measured at each step under steady state conditions. Thereafter, the initial perfusion conditions (afterload and $\left[\mathrm{Ca}^{2+}\right]_{\mathrm{e}}$ equal to $8.0 \mathrm{kPa}$ and $2.25 \mathrm{mM}$, respectively) were reinstalled, and it was tested whether the interventions, i.e., changes in $\left[\mathrm{Ca}^{2+}\right]_{e}$ and afterload, induced significant residual modifications of the relevant hemodynamic variables.

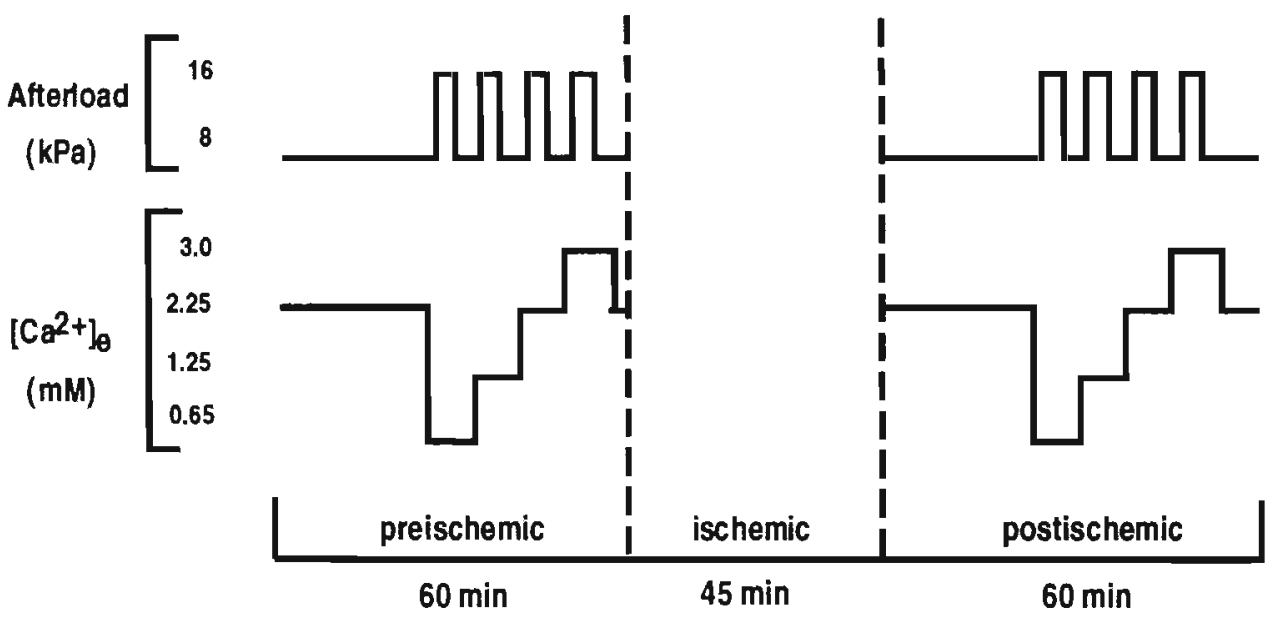

Figure 1: Schematic presentation of the experimental protocol. Rat hearts were subjected to changes in $\left[\mathrm{Ca}^{2+}\right]_{e}$ in combination with changes in afterload, preischemically as well as postischemically.

At the end of the $60 \mathrm{~min}$ preischemic period, all hearts were subjected to a $45 \mathrm{~min}$ global ischemia period by closing the left atrial and aortic cannulas. During this ischemic period the intramyocardial temperature dropped gradually to $30-32{ }^{\circ} \mathrm{C}$. After ischemia, all hearts were reperfused at an afterload of $8.0 \mathrm{kPa}$ and $\left[\mathrm{Ca}^{2+}\right]_{\mathrm{e}}$ equal to $2.25 \mathrm{mM}$. Initially the hearts were reperfused for $15 \mathrm{~min}$ in the retrograde way. Then the hearts were allowed to work antegradely for $20 \mathrm{~min}$. At the end of this period, functional recovery was calculated as the percentage recovery of the hemodynamic values compared to the preischemic values, recorded under steady 
state conditions immediately before the start of the ischemic period. Subsequently, postischemic cardiac performance was again challenged during 25 min by varying both $\left[\mathrm{Ca}^{2+}\right]_{\mathrm{e}}$ and afterload, identical to the protocol followed during the preischemic period. The hearts were electrically paced at $5 \mathrm{~Hz}$ throughout the experiments, except during ischemia and the first $10 \mathrm{~min}$ of reperfusion. During the first $15 \mathrm{~min}$ of reperfusion, the coronary effluent was collected, stored on ice, and monitored spectrophotometrically for the presence of creatine kinase, according to Bergmeyer and Bernt [2], using a Cobas Bio autoanalyser.

\section{Statistical analysis}

All values are expressed as mean $\pm S D$. Related data within each group were compared for statistical significances using one-way of variance and Bonferroni's test. Effects of interventions in the two groups during the preischemic and postischemic period were evaluated for statistical significance by the Wilcoxon's matched-pairs signed-ranks test. Values of $p \leq 0.05$ were considered to be statistically significant.

\section{RESULTS}

Preischemic hemodynamic function: The steady state values of the preischemic hemodynamic variables at different $\left[\mathrm{Ca}^{2+}\right]_{e}$ and afterloads are presented in Table 1. At an afterload of $8.0 \mathrm{kPa}$ and $\left[\mathrm{Ca}^{2+}\right]_{e}$ of $0.65 \mathrm{mM}$, heat-shocked hearts performed significantly less well than the corresponding control hearts, as evidenced by the significantly lower values of $\mathrm{CO}$ and positive and negative $\mathrm{dP} / \mathrm{dt}_{\max }$. $\mathrm{CO}$ was also significantly lower in the group of heat-shocked hearts at $\left[\mathrm{Ca}^{2+}\right]_{e}$ equal to $1.25 \mathrm{mM}$. At high $\left[\mathrm{Ca}^{2+}\right]_{\mathrm{e}}$ (up to $3.0 \mathrm{mM}$ ) no significant differences were observed between the two groups of hearts. At high afterload $(16.0 \mathrm{kPa})$, the ability of heat-shocked hearts to eject was depressed at all $\left[\mathrm{Ca}^{2+}\right]_{\mathrm{e}}$, as illustrated by the significantly lower $\mathrm{CO}$ values in these hearts compared to the control hearts. At this afterload the LVDP and positive and negative $\mathrm{dP} / \mathrm{dt}_{\max }$ values were not statistically different in heatshocked and control hearts. After reinstalling the basal perfusion conditions (afterload $=8.0 \mathrm{kPa}$ and $\left[\mathrm{Ca}^{2+}\right]_{e}=2.25 \mathrm{mM}$ ), following the complete challenge period, cardiac performance of individual hearts was found to be not significantly different from the pre-interventions period. The percentage difference in cardiac performance between post and pre challenge varied from $0 \% \pm 2 \%$ (CO in the control group) to $7 \% \pm 9 \%$ (negative $\mathrm{dP} / \mathrm{dt}_{\max }$ in the heat-shocked group, $\mathrm{ns}$ ). This indicated that the hearts in both groups tolerated very well these interventions.

\section{Postischemic hemodynamic function and biochemical analysis}

Functional recovery: All hearts were reperfused at an afterload of $8.0 \mathrm{kPa}$ and a $\left[\mathrm{Ca}^{2+}\right]_{\mathrm{e}}$ of $2.25 \mathrm{mM}$ before the second challenge period. Figure 2 shows the maximally attained postischemic percentage recovery of the various hemodynamic variables, measured immediately before the challenge $(t=35 \mathrm{~min}$ after the start of reperfusion). $\mathrm{CO}$ recovery was significantly better in Lew $\mathrm{HS}$ (73\% of the preischemic value) than in the Lew $C$ hearts $(51 \%)$. Also the postischemic recovery of positive $(78 \%)$ and negative $\mathrm{dP} / \mathrm{dt}_{\max }(86 \%)$ was significantly better in heat-shocked than in 


\section{Chapter 6}

control hearts $(69 \%$ and $71 \%$, respectively). The recovery of LVDP was not significantly different in both groups. In addition, the total duration of electrical instability, characterized by short periods of ventricular fibrillation, tachycardia or irregular ectopic beats, was significantly reduced in the heat-shocked hearts $(13.6 \pm$ $3.4 \mathrm{~min}$ in control hearts, $6.2 \pm 5.0 \mathrm{~min}$ in heat-shocked hearts; $p<0.05)$. During the initial $15 \mathrm{~min}$ reperfusion period, heat-shocked hearts lost $14.1 \pm 2.1 \mathrm{U} / \mathrm{g}$ wet weight creatine kinase, whereas the control hearts lost $16.8 \pm 1.7 \mathrm{U} / \mathrm{g}$ wet weight.

Table 1: Preischemic hemodynamic values in isolated, ejecting hearts of anesthetized (Lew $w ; n=6)$ and heat-shocked (Lew $w_{S} ; n=6$ ) Lewis rats, subjected to different extracellular calcium ion concentrations $\left(\left[\mathrm{Ca}^{2+}\right]_{e}\right)$ and perfused at afterload levels of 8.0 and $16.0 \mathrm{kPa}$

$\left[\mathrm{Ca}^{2+}\right]_{\mathrm{e}}$

\begin{tabular}{cccc}
$0.65 \mathrm{mM}$ & $1.25 \mathrm{mM}$ & $2.25 \mathrm{mM}$ & \multicolumn{2}{c}{$3.0 \mathrm{mM}$} \\
LewC LewHS & LewC LewHS & LewC LewHS & LewC LewhS
\end{tabular}

Afterload $8.0 \mathrm{kPa}$

$\mathrm{CO}$

LVDP

$+\mathrm{dP}_{\mathrm{dPax}}$

$-\mathrm{dP} / \mathrm{dt}_{\max }$

\section{Afterload 16.0 kPa}

$\mathrm{CO}$

LVDP

$+\mathrm{dP} / \mathrm{dt}_{\text {max }}$

$-\mathrm{dP} / \mathrm{dt}_{\max }$
$43 \pm 11 \quad 14 \pm 5^{*} \quad 65 \pm 13 \quad 50 \pm 5^{*}$

$\begin{array}{llll}8.2 \pm 0.1 & 7.5 \pm 0.5 & 9.0 \pm 0.8 & 9.0 \pm 0.3\end{array}$

$304 \pm 20 \quad 246 \pm 35^{*} 445 \pm 66 \quad 404 \pm 35$

$214 \pm 8 \quad 147 \pm 32^{*} 331 \pm 27 \quad 295 \pm 44$

$13 \pm 4 \quad 4 \pm 6^{*} \quad 22 \pm 15 \quad 1 \pm 2^{*}$

$12.1 \pm 1.412 .9 \pm 2.713 .8 \pm 1.312 .8 \pm 1.7$

$\begin{array}{llll}413 \pm 30 & 442 \pm 106514 \pm 74 & 454 \pm 67\end{array}$

$191 \pm 19 \quad 208 \pm 73271 \pm 105 \quad 183 \pm 34$
$80 \pm 7 \quad 76 \pm 5 \quad 90 \pm 5 \quad 82 \pm 9$

$10.5 \pm 0.6 \quad 11.4 \pm 0.911 .1 \pm 0.6 \quad 11.2 \pm 1.0$

$\begin{array}{lllll}684 \pm 52 & 679 \pm 74 & 782 \pm 67 & 707 \pm 100\end{array}$

$\begin{array}{llll}385 \pm 28 & 396 \pm 63 & 379 \pm 57 & 374 \pm 45\end{array}$

Data are presented as mean values $\pm \mathrm{s} . \mathrm{d}$. CO: cardiac output $(\mathrm{ml} / \mathrm{min})$; LVDP: left ventricular developed pressure $(\mathrm{kPa}) ; \pm \mathrm{dP} / \mathrm{dt}_{\text {max }}$ : positive and negative maximal first derivative of left ventricular pressure $(\mathrm{kPa} / \mathrm{s})$, respectively; ${ }^{*}$ : significantly different from the values in the corresponding control group.

\section{Effects of $\left[\mathrm{Ca}^{2+}\right]_{e}$ in combination with afterload.}

After the above mentioned recovery period, postischemic performance was again tested by changing $\left[\mathrm{Ca}^{2+}\right]_{\mathrm{e}}$ and afterload. At normal $\left[\mathrm{Ca}^{2+}\right]_{\mathrm{e}}$, i.e., 1.25 to $2.25 \mathrm{mM}$, and an afterload level of $8.0 \mathrm{kPa}$, left ventricular performance was significantly better in Lew HS than in the corresponding Lew ${ }_{C}$ hearts (Table 2). No statistically significant differences were found between both groups of hearts at $\left[\mathrm{Ca}^{2+}\right]_{\mathrm{e}}$ of $0.65 \mathrm{mM}$. At the highest $\left[\mathrm{Ca}^{2+}\right]_{\mathrm{e}}$ level, i.e., $3.0 \mathrm{mM}$, only left ventricular relaxation was significantly better in LewHS than LewC hearts (Table 2). When the afterload was increased to $16.0 \mathrm{kPa}$, improvement of postischemic function afforded by heat shock completely disappeared. Only LVDP was significantly higher in Lew ${ }_{H S}$ than in LewC hearts at $\left[\mathrm{Ca}^{2+}\right]_{\mathrm{e}}$ of $1.25 \mathrm{mM}$ and higher. Positive and negative $\mathrm{dP} / \mathrm{dt}_{\max }$ were not significantly different in the two groups at all $\left[\mathrm{Ca}^{2+}\right]_{e}$ tested. Moreover, $\mathrm{CO}$ was significantly lower in Lew ${ }_{H S}$ than in LewC hearts at the two lowest $\left[\mathrm{Ca}^{2+}\right]_{e}$ tested. Again no significant differences in cardiac performance before and after the interventions were observed. During this postischemic period differences between the preintervention and post-intervention values were less than $5 \%$. 


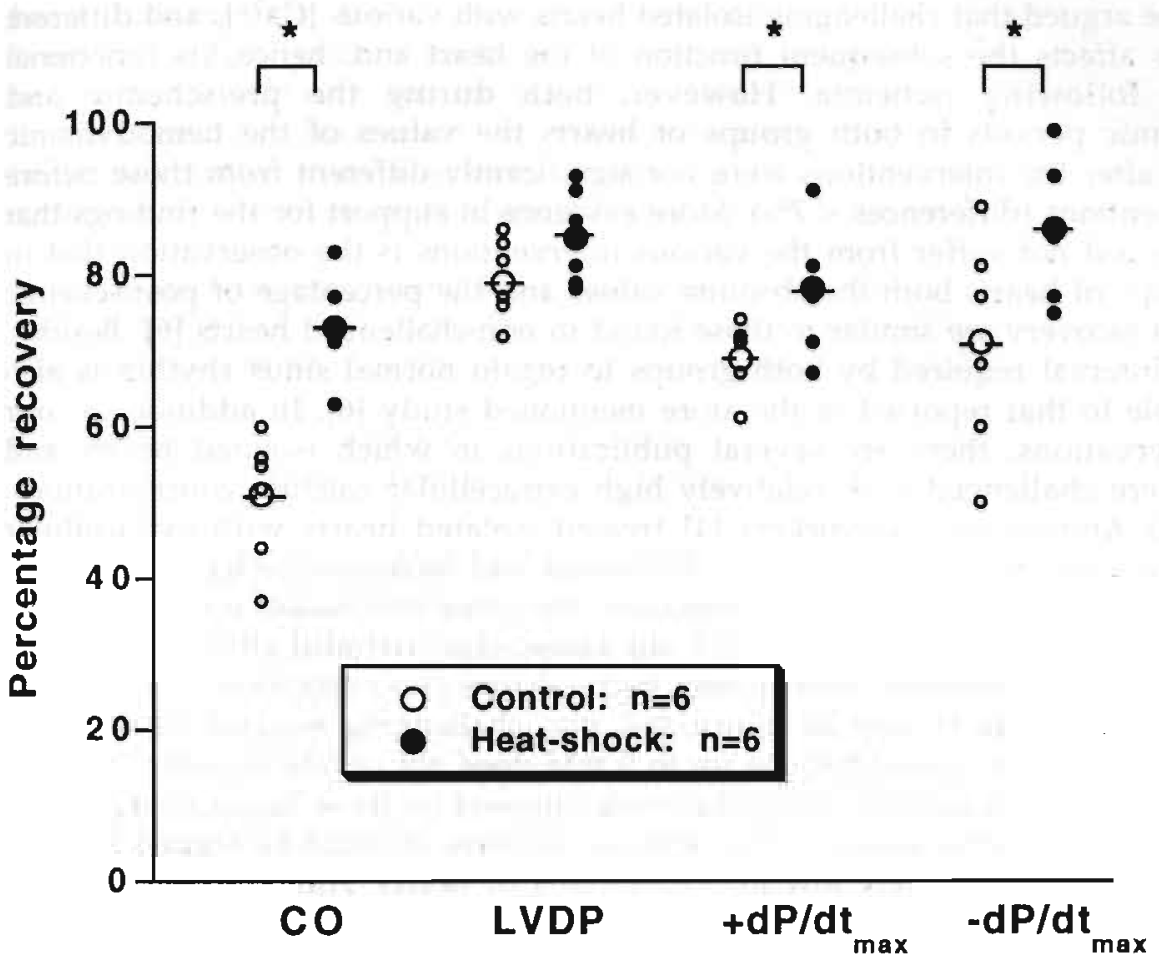

Figure 2: Individual postischemic functional recovery of isolated, ejecting hearts of control and heat-shocked rats. All hearts were reperfused at an afterload of $8.0 \mathrm{kPa}$ and a $\left[\mathrm{Ca}^{2+}\right]$ e of $2.25 \mathrm{mM}$. CO: cardiac output; LVDP: left ventricular developed pressure; $\pm \mathrm{dP} / \mathrm{dt}_{\text {max }}$ : positive and negative maximal first derivative of left ventricular pressure, respectively. Horizontal lines on large circles represent mean values. ": significantly different from values in the control group.

\section{DISCUSSION}

A variety of studies has shown that heat shock pretreatment improves the postischemic recovery of cardiac performance $[5 ; 7 ; 29]$. The findings of the present study confirm the beneficial effects of heat shock in the reperfused rat heart. However, they also demonstrate that heat shock pretreatment seriously impairs the ability of the myocardium to adapt to altered hemodynamic conditions. Preischemically cardiac output is depressed more in the heat-shocked than in the control heart when it has to eject against a relatively high afterload. Furthermore, although the postischemic recovery is significantly improved in the heat-shocked heart when it performs at a relatively low afterload at extracellular calcium concentrations of 1.25 and $2.25 \mathrm{mM}$, cardiac function is so profoundly depressed at higher afterload that heat shock pretreatment affords no beneficial effect at normal extracellular calcium concentrations and becomes deleterious at low extracellular calcium concentrations. 


\section{Discussion regarding the model used}

It could be argued that challenging isolated hearts with various $\left[\mathrm{Ca}^{2+}\right]_{e}$ and different afterloads affects the subsequent function of the heart and, hence, its functional recovery following ischemia. However, both during the preischemic and postischemic periods in both groups of hearts the values of the hemodynamic variables after the interventions were not significantly different from those before the interventions (differences $<7 \%$ ). More evidence in support for the findings that the hearts did not suffer from the various interventions is the observation that in both groups of hearts both the absolute values and the percentage of postischemic functional recovery are similar to those found in non-challenged hearts [6]. Besides, the time-interval required by both groups to regain normal sinus rhythm is also comparable to that reported in the afore mentioned study [6]. In addition to our own observations, there are several publications in which isolated hearts and tissues were challenged with relatively high extracellular calcium concentrations. Callens-El Amrani and co-workers [4] treated isolated hearts with extracellular calcium concentrations up to $3 \mathrm{mM}$ in decreasing and increasing order without any obvious negative effects on cardiac function. The same conclusion was reached by other investigators [13]. To the best of our knowledge, harmful effects on cardiac function are only observed at extremely high calcium concentrations $[1 ; 16]$. Based upon these findings it may be concluded that challenging isolated hearts with extracellular calcium concentrations up to $3 \mathrm{mM}$ does not negatively interfere with normal cardiac function and, hence, the stress imposed on these hearts is negligible.

As related to the length of the ischemic episode, it could be argued that the resulting injury is relatively low in both groups of hearts. Although it cannot be excluded that the temperature drop of $5^{\circ} \mathrm{C}$ during the ischemic episode affords some cardioprotection it should be emphasized that functional recovery is also affected by the characteristics of the artificial aortic cannula. In this experimental set-up a lot of attention has been paid to the physical properties of the artificial aortic outflow tract, leading to impedance characteristics of the aortic cannula which approach those of the systemic circulation in-vivo [26].

The findings on enzyme release indicate that a comparable irreversible injury occurred in both types of hearts. In an earlier study of our group we documented enzyme loss in heat-shocked and control hearts during the full 45 min of reperfusion without any challenge [5]. Since the enzyme release during the first 15 min in both groups was identical to that recorded in the corresponding groups in the present study, we can estimate enzyme loss over the full reperfusion period. As such both groups of hearts would have lost about $10 \%$ of the total tissue creatine kinase content. Since no significant differences in enzyme loss in both groups are found, the better functional recovery in the heat-shocked heart cannot be attributed to differences in irreversible damage. However, it cannot be excluded that stunning has occurred in the investigated hearts. In that case, less stunning may be responsible for the better recovery in the heat-shocked hearts. It should however be emphasized that the isolated rat heart model is not ideal to investigate stunning. By definition stunning reflects reversible damage followed by normalization of cardiac function after days to weeks.

\section{The effect of heat shock on normoxic left ventricular function}

In the present study, normoxic function of the heat-shocked heart, perfused at the standard $\left[\mathrm{Ca}^{2+}\right]_{\mathrm{e}}$ of $2.25 \mathrm{mM}$, is completely comparable to that of the control heart at the relatively low afterload of $8.0 \mathrm{kPa}$. However, when afterload is increased, cardiac 
output is significantly more depressed in the heat-shocked than in the control heart. Interestingly, the contractility index $\mathrm{dP} / \mathrm{dt}_{\max }$ is not statistically different between the two types of hearts at this relatively high afterload. Since preload and heart rate are kept constant, the reduced cardiac output cannot be directly attributed to a depression in contractility as assessed by positive $\mathrm{dP} / \mathrm{dt}_{\max }$. The heat-shocked heart may suffer from a reduced filling, e.g. due to a decreased compliance, or suffers from a reduced systolic ejection time. The present experimental setup,

Table 2: Postischemic hemodynamic values (after 20 min of antegrade reperfusion) in isolated, ejecting hearts of anesthetized (Lew $; n=6$ ) and heat-shocked (Lew $w_{S} ; n=6$ ) Lewis rats, subjected to different extracellular calcium ion concentrations $\left(\left[\mathrm{Ca}^{2+}\right]_{e}\right)$ and perfused at afterload levels of 8.0 and $16.0 \mathrm{kPa}$

\begin{tabular}{lccccc}
\hline $\left.\mathrm{Ca}^{2+}\right] \mathrm{e}$ & $0.65 \mathrm{mM}$ & $1.25 \mathrm{mM}$ & $2.25 \mathrm{mM}$ & $3.0 \mathrm{mM}$ \\
& LewC LewHS LewC LewhS & LewC LewHS LewC LewhS
\end{tabular}

\section{Afterload $8.0 \mathrm{kPa}$}

$\begin{array}{lcccccccc}\mathrm{CO} & 17 \pm 7 & 12 \pm 6 & 21 \pm 8 & 35 \pm 7^{*} & 41 \pm 9 & 56 \pm 8^{*} & 54 \pm 16 & 65 \pm 10 \\ \mathrm{LVDP} & 7.2 \pm 0.5 & 7.2 \pm 0.3 & 6.2 \pm 1.2 & 8.2 \pm 1.1^{*} & 8.4 \pm 0.8 & 9.6 \pm 1.0^{*} & 9.2 \pm 0.9 & 10.2 \pm 0.9 \\ +\mathrm{dP} / \mathrm{dt}_{\max } & 294 \pm 29 & 261 \pm 37 & 269 \pm 50 & 375 \pm 95^{*} & 459 \pm 53 & 514 \pm 92 & 541 \pm 84 & 602 \pm 73 \\ -\mathrm{dP} / \mathrm{dt}_{\max } & 165 \pm 12 & 158 \pm 21 & 149 \pm 37 & 259 \pm 67^{*} & 268 \pm 44 & 324 \pm 55^{*} & 298 \pm 47 & 365 \pm 42^{*}\end{array}$

\section{Afterload $16.0 \mathrm{kPa}$}

\begin{tabular}{|c|c|c|c|c|c|c|c|c|}
\hline & $10 \pm 5$ & $2 \pm 2^{*}$ & $10 \pm 7$ & $1 \pm 2^{*}$ & $8 \pm 4$ & $13 \pm 12$ & $21 \pm 15$ & $24 \pm 20$ \\
\hline $\begin{array}{l}\text { LVDP } \\
+\mathrm{dP} / \mathrm{dt}_{\max }\end{array}$ & $\begin{array}{l}10.1 \pm 4.1 \\
393 \pm 156\end{array}$ & $\begin{array}{l}11.1 \pm 2.7 \\
411 \pm 119\end{array}$ & $\begin{array}{l}7.3 \pm 1.9 \\
291 \pm 61\end{array}$ & $\begin{array}{c}10.8 \pm 1.3^{*} \\
399 \pm 90\end{array}$ & $\begin{array}{c}12.1 \pm 1.8 \\
457 \pm 85\end{array}$ & $\begin{array}{r}314.6 \pm 1.5^{*} \\
570 \pm 126\end{array}$ & $\begin{array}{l}14.4 \pm 1.5 \\
582 \pm 122\end{array}$ & $\begin{array}{l}15.9 \pm 1.2^{*} \\
670 \pm 151\end{array}$ \\
\hline $\mathrm{dP} / \mathrm{dt}_{\mathrm{m}}$ & $191 \pm 68$ & $193 \pm 50$ & $144 \pm 23$ & $175 \pm 31$ & $233 \pm 30$ & $315 \pm 111$ & $318 \pm 93$ & $430 \pm 139$ \\
\hline
\end{tabular}

Data are presented as mean values $\pm \mathrm{s} . \mathrm{d}$. CO: cardiac output $(\mathrm{ml} / \mathrm{min}) ; \mathrm{LVDP}$ : left ventricular developed pressure $(\mathrm{kPa}) ; \pm \mathrm{dP}_{\mathrm{dt}} \mathrm{dtax}_{\max }$ positive and negative maximal first derivative of left ventricular pressure $(\mathrm{kPa} / \mathrm{s})$, respectively; ${ }^{*}$ : significantly different from the values in the corresponding control group.

however, does not allow the measurement of enddiastolic left ventricular volume or ejection fraction. Therefore, the actual parameter(s) responsible for the diminished cardiac output at high afterload is (are) difficult to identify. Our studies strongly suggest that contractility of the heat-shocked heart is not directly involved, since it is not affected, at least at the $\left[\mathrm{Ca}^{2+}\right]_{\mathrm{e}}$ levels between 0.65 and $2.25 \mathrm{mM}$.

Increasing the extracellular $\mathrm{Ca}^{2+}$ concentration is known to increase $\mathrm{Ca}^{2+}$ influx through slow L-type channels, which in turn increases $\mathrm{Ca}^{2+}$ release from the sarcoplasmatic reticulum [12] and, hence, increases contractile force [4]. In the present study, no major differences in functional performance between the normal and heat-shocked heart are observed at an afterload of $8.0 \mathrm{kPa}$, except at the very low $\left[\mathrm{Ca}^{2+}\right]_{e}$ of 0.65 and the normal $\left[\mathrm{Ca}^{2+}\right]_{e}$ of $1.25 \mathrm{mM}$, where cardiac output is significantly more impaired in the heat-shocked heart. At the lowest $\mathrm{Ca}^{2+}$ concentration positive $\mathrm{dP} / \mathrm{dt}_{\max }$ is also depressed, suggesting that limited $\mathrm{Ca}^{2+}$ is available for the contractile apparatus or the sensitivity of the contractile apparatus towards calcium is decreased. Since it is known that some HSPs like HSP70 contain a calmodulin binding site [25], it is postulated that during normoxia increased binding of HSP72 to calmodulin influences the normal contraction process. 
The effect of heat shock on postischemic function.

Using different experimental models, it has been shown that heat shock pretreatment confers protection to the ischemic heart. This phenomenon can be observed in the isolated, retrogradely as well as antegradely perfused rat and rabbit heart $[6,7,29]$. In all these models, however, the left ventricular loading conditions were ratier favourable. In the retrogradely perfused heart loading is almost absent, while in the described antegradely perfused hearts, as in the present study, the afterload levels were kept relatively low. Until now, only limited information was available on the cardiac performance after heat shock under less favourable loading conditions. Our group [6] and others [28] have described the absence of postischemic improvement of cardiac function in the heat-shocked heart when afterload is increased to or above $10 \mathrm{kPa}$. The present findings confirm and extend these observations. They show that, as already established, hyperthermic pretreatment clearly benefits postischemic cardiac performance at an afterload of $8.0 \mathrm{kPa}$, but not of $16.0 \mathrm{kPa}$. As such, these results are in agreement with the data obtained preischemically, where the decrease in cardiac output at this high afterload is more pronounced in the heat-shocked than in the control heart.

It is generally accepted that excessive accumulation of $\mathrm{Ca}^{2+}$ ions occurs in cardiomyocytes after prolonged periods of ischemia [20] and that lowering the extracellular calcium concentration upon reperfusion improves functional recovery [11]. We speculated that the heat-shocked heart is better able to handle excessive $\mathrm{Ca}^{2+}$ influx since it is less vulnerable to a submaximal calcium paradox [17], the postischemic mitochondrial ultrastructure is better preserved, and less $\mathrm{Ca}^{2+}$ accumulates in these organelles [7; 29]. In a study by Das and coworkers (Das et al., 1989) it was found that myocardial dysfunction induced by ischemia/reperfusion could be improved significantly by using a specific calmodulin antagonist. Since HSP70 has a specific calmodulin binding site [25], it is possible that the protein acts as a calmodulin antagonist.

Challenging the postischemic heat-shocked heart with variable extracellular calcium concentrations confirms at least that these hearts are able to handle high $\mathrm{Ca}^{2+}$ concentrations without considerable negative consequences. Besides, as under preischemic conditions, changes in $\left[\mathrm{Ca}^{2+}\right]_{e}$ at low afterload do not affect differentially the heat-shocked and control heart, except at the lowest $\left[\mathrm{Ca}^{2+}\right]_{e}$ tested. This findings suggest again that at low $\left[\mathrm{Ca}^{2+}\right]_{e}$ a lower amount of intracellular $\mathrm{Ca}^{2+}$ ions is available for contraction than in the control heart. This phenomenon is also observed at high afterload.

In conclusion, preischemic left ventricular performance of the isolated heatshocked heart is depressed when it performs at low $\left[\mathrm{Ca}^{2+}\right]_{e}$ or against a relatively high afterload. The heat shock-mediated improvement of postischemic function can only be appreciated at relatively low afterload levels in combination with normal extracellular calcium concentrations.

\section{LITERATURE}

1. Abdelmequid A.E., J.J. Feher, 1992. Effect of $\left[\mathrm{Ca}^{2+}\right]$ on cardiac sarcoplasmic reticulum $\mathrm{Ca}^{2+}$ release channel in isolated rat hearts. Circ Res 71: 1049-1058.

2. Bergmeyer H.U., E. Bernt, 1974. UV assay for creatine kinase. In: Methods of Enzymatic Analysis, edited by H.U. Bergmeyer, Weinheim, Germany: Verlag Chemie vol 2: 784-788. 
3. Brown J.M., M.A. Grosso, L.S. Terada, G.J.R. Whitman, A. Banerjee, C.W. White, A.H. Harken, J.E. Repine, 1989. Endotoxin pretreatment increases endogenous myocardial catalase activity and decreases reperfusion injury of isolated rat hearts. Proc Nat1 Acad Sci USA 86: 2516-2520.

4. Callens-El Amrani F., E. Mayoux, C .Mouas, R. Clapier-Ventura, D. Henzel, D. Charlemange, B. Swyngedauw, 1990. Normal responsiveness to external $\mathrm{Ca}$ and to Ca-channel modefying agents in hypertrophied rat heart. Am J Physiol 258: H1727-H1734.

5. Cornelussen R., L.G. de Bruin, G.J. van der Vusse, L.H.E.H. Snoeckx, 1994. Is the post-ischemic heat shock mediated protection of the hypertrophied rat heart perfusion pressure dependent? In: International Society for heart research: European section meeting. Copenhagen (Denmark) (Eds.) S Haunso and K Kjeldsen. Monduzzi Editore, Bologna: 559-563.

6. Comelussen R., W. Spiering, J.H.G. Webers, L.G. de Bruin, R.S. Reneman, G.J. van der Vusse, L.H.E.H. Snoeckx, 1994. Heat shock improves the ischemic tolerance of the hypertrophied rat heart. Am J Physiol 267: H1941-H1947.

7. Currie R.W., M. Karmazyn, M. Kloc, K. Mailer, 1988. Heat shock response is associated with enhanced post-ischemic recovery. Circ Res 63: 543-549.

8. Currie R.W., R.M. Tanguay, J.J. Kingma, 1993. Heat shock response and limitation of tissue necrosis during occlusion/reperfusion in rabbit hearts. Circulation 87: 963-971.

9. Das D.K., R.M. Engelman, M.R. Prasad, J.A. Rousou, R.H. Breyer, R .Jones, H. Young, G.A. Cordis, 1989. Improvement of ischemia-reperfusion-induced myocardial dysfunction by modulating calcium overload using a novel, specific calmodulin antagonist, CGS 9343B. Biochem Pharm 38: $465-471$.

10. Donnelly T.J., R..E. Sievers, F.L. Vissern, W.J. Welch, C.L. Wolfe, 1991. Heat shock protein induction in rat hearts. A role for improved myocardial salvage after ischemia and reperfusion. Circulation 85: 769-778.

11. du Toit E.F., L.H. Opie, 1992. Modulation of severity of reperfusion stunning in the isolated rat heart by agents altering calcium flux at onset of reperfusion. Circ Res 70: 960-967.

12. Fabiato A., 1983. Calcium induced release of calcium from the sarcoplasmic reticulum. Am J Physiol 245: C1-C14.

13. Fellenius E., C.A. Hansen, O. Mjos, J.R. Neely, 1985. Chronic infarction decreases maximum cardiac work and sensitivity of heart to external calcium. Am J Physiol 249: $\mathrm{H} 80-\mathrm{H} 87$.

14. Heads R.J., D.S. Latchman, D.M. Yellon, 1994. Stable high level expression of a transfected human HSP70 gene protects a heart-derived muscle cell line against thermal stress. J Mol Cell Cardiol 26: 695-699.

15. Hutter M.M., R.E .Sievers, V. Barbosa, C.L.Wolfe, 1994. Heat shock protein induction in rat hearts. A direct correlation between the amount of heat shock protein induced and the degree of myocardial protection. Circulation 89: 355-60.

16. Kitakaze M., H.F. Weisman, E. Marban, 1988. Contractile dysfunction and ATP depletion after transient calcium overload in perfused ferret hearts. Circulation 77: 685-695.

17. Marber M.S., J.M. Walker, D.S. Latchman, D.M. Yellon, 1993. Attenuation by heat stress of a submaximal calcium paradox in the rabbit heart. J Mol Cell Cardiol 25: 1119-1126.

18. Marber M.S., J.M. Walker, D.S. Latchman, D.M. Yellon, 1994. Myocardial protection after whole body heat stress in the rabbit is dependent on metabolic substrate and is related to the amount of the inducible 70-kD heat stress protein. J Clin Invest 93: 1087-1094.

19. Maulik N., Wei Z., X. Liu, R.M. Engelman, J.A. Rousou, D.K. Das, 1994. Improved postischemic ventricular functional recovery by amphetamine is linked with its ability to induce heat shock. Mol Cell Biochem 137: 17-24.

20. Nayler W.G., 1981. The role of calcium in the ischemic myocardium. Am J Pathol 102: 262-270.

21. Pallaros D.R., W.J. Welch, A.L. Flink, 1991. Interaction of HSP70 with unfolded proteins: effects of temperature and nucleotides on the kinetics of binding. Proc Natl Acad Sci 88: 5719-5723.

22. Sanders Williams R., J. Thomas, M. Fina, Z. German, I. Benjamin, 1993. Human heat shock protein 70 (HSP70) protects murine cells from injury during metabolic stress. J Clin Invest 92: 503-508.

23. Snoeckx L.H.E.H., J.J. Schrijen, M. van Bilsen, W.J. Lammers, T. van der Nagel, G.J. van der Vusse, R Reneman, 1986. A microcomputer system for hemodynamic measurements in isolated, working rat hearts. Comp Biol Med 4: 301-309.

24. Snoeckx L.H.E.H., G.J. van der Vusse, F. van der Veen, W.A. Coumans, R.S. Reneman, 1989. Recovery of hypertrophied rat hearts after global ischemia and reperfusion at different perfusion pressures. Pflügers Arch (Eur J Physiol) 413: 303-312.

25. Stevenson M., S. Calderwood, 1990. Members of the 70-kilodalton heat shock protein family contain a highly conserved calmoduline-binding domain. Mol Cell Biol 10: 1234-1238. 
26. van Bilsen M., L.H.E.H. Snoeckx, T. Arts, G.J. van der Vusse, R.S. Reneman, 1991. Performance of the isolated, ejecting heart: Effects of aortic impedance and exogenous substrates. Pflügers Arch (Eur J Physiol) 419: 7-12.

27. Walker D.M., S. Kucukoglu, M.S. Marber, E. Iliodromites, R. Ferrari, D.M. Yellon, 1993. Heat stress limits infarct size in the isolated perfused rat heart. Cardiovasc Res 27: 962-967.

28. Wall S., H. Fliss, B. Korecky, 1993. Role of catalase in myocardial protection against ischemia in heat-shocked rats. Mol Cell Biochem 129: 187-194.

29. Yellon DM., E. Pasini, A. Cargnoni, M.S. Marber, D.S. Latchman, R. Ferrari, 1992. The protective role of heat stress in the ischaemic and reperfused rabbit myocardium. J Mol Cell Cardiol 24: 895907. 


\section{Chapter 7}

\section{CALCIUM HOMEOSTASIS IN CARDIOMYOCYTES ISOLATED FROM HEAT-SHOCKED HEARTS}

This study is in press as "Calcium homeostasis in cardiomyocytes isolated from heat-shocked rats" by R. Cornelussen, L. Ver Donck, G. Verellen, M. Borgers, G.J. van der Vusse, R.S. Reneman and L.H.E.H. Snoeckx in Am. J. Physiol. 


\section{ABSTRACT}

The cellular mechanism of heat shock-mediated cardioprotection is still under debate. Since heat pretreatment negatively affects the normoxic in vitro left ventricular contractile performance when the extracellular $\mathrm{Ca}^{2+}$-concentration $\left(\left[\mathrm{Ca}^{2+}\right]_{\mathrm{e}}\right)$ is relatively low $(0.65-1.25 \mathrm{mM})$, the intracellular $\mathrm{Ca}^{2+}$-homeostasis was studied in more detail in cardiomyocytes isolated from adult rats $24 \mathrm{~h}$ after heat stress $\left(42^{\circ} \mathrm{C}\right.$ for $15 \mathrm{~min}$ ) or anesthesia (Control). Sensitivity to $\mathrm{Ca}^{2+}$-overload was assessed by exposure to veratridine (quiescent cells), or to $\left[\mathrm{Ca}^{2+}\right]_{e}$ ranging from 0.125 to $20 \mathrm{mM}$ in quiescent and paced cardiomyocytes. The fraction of irreversibly hypercontracted cells was not different in both groups. The FURA-2 fluorescence ratio (i340/i380), which was used as a measure for the cytoplasmic $\mathrm{Ca}^{2+}$ concentration $\left[\mathrm{Ca}^{2+}\right]_{i}$ in quiescent cells following exposure to $\left[\mathrm{Ca}^{2+}\right]_{e}(0.5-10 \mathrm{mM})$, was also not different between both groups. Myofilament $\mathrm{Ca}^{2+}$-sensitivity was assessed in paced $(0.5 \mathrm{~Hz})$ cells by measuring simultaneously the $\left[\mathrm{Ca}^{2+}\right]_{\mathrm{i}}$-transients and cell shortening. At stepwise increases of $\left[\mathrm{Ca}^{2+}\right]_{\mathrm{e}}$ from 1 to $10 \mathrm{mM}$, these parameters were comparable in both groups. The diastolic cell length shortened progressively and equally in both groups following increasing $\left[\mathrm{Ca}^{2+}\right]_{\mathrm{e}}$. However, within $2 \mathrm{~min}$ upon return from 10 to $1 \mathrm{mM}\left[\mathrm{Ca}^{2+}\right]_{\mathrm{e}}$, cells from heat-shocked rats retained the same length, while cells from control rats contracted further $(p=0.05)$. These data suggest that heat stress improves relaxation following challenge with high $\left[\mathrm{Ca}^{2+}\right]_{\mathrm{e}}$.

\section{INTRODUCTION}

It has been shown that stressful conditions such as heat, amphetamine or endotoxin exposure can confer protection of the heart against ischemic insults $[2 ; 8 ; 14]$. This phenomenon has been documented in several species, such as rat, rabbit, and pig, and under different ischemic and postischemic experimental conditions, such as low-flow or complete ischemia in the Langendorff or ejecting isolated heart and regional ischemia in the heart in vivo $[5 ; 8 ; 9 ; 14]$. All these experiments, however, were performed on hearts in which the external loading conditions were favorable. In contrast, no clear postischemic cardiac protection was observed in heat-shocked hearts when the heart had to eject against elevated aortic pressures [4;21]. These observations suggest that the contractile apparatus of the post-ischemic heatshocked heart is behaving differently from the normal heart. One of the possible explanations for this phenomenon is that intracellular calcium-homeostasis is altered in the heat-shocked heart, due to, for instance altered beat-to-beat calcium availibility or changed sensitivity of the contractile apparatus to calcium. Evidence is accumulating that calcium handling is indeed altered in the heat-shocked heart [3; 22]. Under normoxic conditions left ventricular contractile performance of the isolated heat-shocked heart is impaired compared to control hearts when extracellular calcium is relatively low (0.65-1.25 mM) [6]. Furthermore, Marber and coworkers showed that heat-shocked hearts exhibit a decreased vulnerability to a submaximal calcium paradox 24 hours after heat shock [13]. These observations are compatible with reduced sensitivity of the contractile apparatus to calcium in hearts from heat-shocked rats. Moreover, in postischemic heat-shocked hearts less calcium is accumulated in the mitochondria $[8 ; 23]$. 
The present experiments were designed to investigate the calcium homeostasis under normal and pathophysiological conditions in cardiomyocytes, isolated from heat-shocked hearts. The experimental set-up with single cells was chosen because transmembrane ion gradients can be easily controlled, allowing the investigation of ion homeostasis. Moreover, isolated cardiomyocytes are a valuable model system to investigate intracellular calcium overload [1] or excitationcontraction coupling. Furthermore, cardiomyocytes or cardiomyocyte-like cells accumulate heat-shock proteins after stress [15]. Finally, enhanced expression of the $72 \mathrm{kDa}$ heat shock protein (HSP72) after transfection of cardiomyocyte-like cells $(\mathrm{H} 9 \mathrm{c} 2)$ has been shown to provide thermotolerance [11] or protection against simulated ischemic injury [15]. This suggests that HSP72 also affords protection of isolated cardiomyocytes against stress-like insults.

To investigate whether heat shock may influence the homeostasis of intracellular calcium in cardiomyocytes, we documented the behavior of both paced and quiescent cells isolated from non-heated and heat-shocked animals at increasing extracellular calcium concentrations, eventually leading to irreversible contracture and rounding (= $\mathrm{Ca}^{2+}$-overload).

\section{MATERIALS AND METHODS}

\section{Heat shock protocol}

All experimental animals were handled following the recommendation from the Declaration of Helsinki and the guiding Principles of Care and Use of Animals. Twenty-four hours before myocyte isolation, rats (adult male Wistar rats; $250 \mathrm{~g}$ body weight) were anesthetized with Hypnorm $(0.01 \mathrm{mg} / 100 \mathrm{~g} \mathrm{b.w}$. fentanyl plus 0.5 $\mathrm{mg} / 100 \mathrm{~g} \mathrm{b.w}$. fluanisone s.c.). Thereafter, the animals were heat-shocked on a temperature-controlled heating pad. Rectal temperature was kept at $42^{\circ} \mathrm{C}$ for $15 \mathrm{~min}$. Non-heat-shocked control animals were subjected to a similar protocol but their body temperature was kept at $37^{\circ} \mathrm{C}$. Twenty two animals were included in this study; 11 animals were heat-shocked and 11 animals served as controls.

\section{Cell isolation}

Twenty-four hours after treatment, cardiomyocytes were enzymatically isolated from the hearts using a modification of the technique described by Ver Donck et al [19]. Animals were anesthetized with fentanyl (0.02 $\mathrm{mg} / \mathrm{kg}$ s.c.). After heparin injection (500 U i.v.), the heart was quickly removed from the thorax and immersed in ice-cold Krebs-Ringer-Henseleit buffer (KRH), supplemented with $5 \mathrm{mM}$ pyruvate. The $\mathrm{KRH}$ buffer consisted of (in mM): $\mathrm{NaCl}(125.0), \mathrm{KCl}$ (2.6), $\mathrm{KH}_{2} \mathrm{PO}_{4}$ (1.2), $\mathrm{MgSO}_{4} .7 \mathrm{H}_{2} \mathrm{O}$ (1.2), HEPES (10.0) and glucose (5.5); ( $\left.\mathrm{pH}=7.3\right)$. After cannulation of the aorta, the heart was retrogradely perfused with $100 \%$ oxygenated pyruvatecontaining $\mathrm{KRH}$ in a non-recirculating mode at $5.5 \mathrm{ml} / \mathrm{min}$ at $32^{\circ} \mathrm{C}$ for $5 \mathrm{~min}$. Thereafter, digestion was started by supplementing the $\mathrm{KRH}$ buffer with $0.06 \%$ collagenase (WAKO Chemicals, Osaka, Japan), $0.1 \%$ bovine serum albumin (BSA, fatty acid free; Sigma, Missouri, USA) and $50 \mu \mathrm{M} \mathrm{CaCl} 2$ at a perfusion flow of 7.5 $\mathrm{ml} / \mathrm{min}$ at $37^{\circ} \mathrm{C}$ for $20 \mathrm{~min}$. Then the heart was removed from the cannula and cut into small pieces, which were transferred to the enzyme-containing perfusion medium $\left(37^{\circ} \mathrm{C}\right)$ supplemented with $1 \% \mathrm{BSA}$, and gently agitated with a serological pipette for 5 to $10 \mathrm{~min}$. The cell suspension was filtered over nylon gauze $(200 \mu \mathrm{m}$ 
pores), brought in $10 \mathrm{ml}$ testtubes, and centrifuged at $25 \mathrm{~g}$ for $2 \mathrm{~min}$. The supernatant was removed and the cell pellet resuspended in approximately $8 \mathrm{ml}$ $\mathrm{KRH}$ supplemented with $25 \mu \mathrm{M} \mathrm{CaCl}$. After a second centrifugation the pellet was resuspended in $4 \mathrm{ml} \mathrm{KRH}$ supplemented with $1 \% \mathrm{BSA}$ and $50 \mu \mathrm{M} \mathrm{CaCl}_{2}$. Subsequently the $\mathrm{Ca}^{2+}$-concentration was increased in 3 consecutive steps by adding $150 \mu \mathrm{M} \mathrm{CaCl}_{2}$ every $3 \mathrm{~min}$. BSA was completely washed away by resuspension in BSA-free KHR plus $1 \mathrm{mM} \mathrm{CaCl} 2$ twice and gentle centrifugation $(25 \mathrm{~g}$ for $90 \mathrm{~s}$ ). Cells were seeded in Falcon 3002 Petri dishes. Myocytes to be used in $\left[\mathrm{Ca}^{2+}\right]_{i}$ measurements were seeded on a glass coverslip mounted on the bottom of the plastic petri dish. Within $15 \mathrm{~min}$, the $\mathrm{Ca}^{2+}$-tolerant, rod-shaped cells attached firmly to the bottom of the dishes and non-attached round cells were washed out. The attached cells were incubated in $\mathrm{KRH}$ buffer supplemented with $1 \mathrm{mM} \mathrm{CaCl} 2$ in an oxygen chamber at room temperature until further use. The described experiments were started one hour after isolation. Isolation of cells from one control and one heat-shocked heart was performed on the same day to avoid day-to-day variation in the yield of isolation as a factor that may influence the quality and overall performance of the cells.

\section{Steady state FURA-2 fluorescence ratio (i340/i380)}

The "cytoplasmic free calcium concentration $\left[\mathrm{Ca}^{2+}\right]_{i}$ " in quiescent (non-contracting) cardiomyocytes was measured, using digital image processing (SCIL-image analysis software) of Fura-2 fluorescence as previously described in detail [10; 20]. In short, quiescent cardiomyocytes were loaded with $5 \mu \mathrm{M}$ Fura-2-AM (Molecular Probes) for $15 \mathrm{~min}$ at $37^{\circ} \mathrm{C}$ in the incubation medium. The cell-containing dish was mounted on the stage of an inverted microscope (Zeiss IM 35), equipped with an automatic scanning stage (Merzhauser). Excitation of the dye was performed at $340 \mathrm{~nm}\left(\mathrm{Ca}^{2+-}\right.$ bound Fura-2) and $380 \mathrm{~nm}$ (unbound Fura-2), respectively. Calculation of the intensities at the two wavelengths (i340 and i380) was performed in the constant threshold mode. The ratio (i340/i380) with background corrections was calculated for each individual cell and used as a measure for $\left[\mathrm{Ca}^{2+}\right]_{\mathrm{i}}$. Four to nine cells from heat-shocked or control rats were examined in each experiment.

\section{Dynamic intracellular $\mathrm{Ca}^{2+}$ measurements}

To determine the myofilament sensitivity to $\mathrm{Ca}^{2+}$, the cytosolic calcium transient and cell length were measured simultaneously in field-stimulated $(0.5 \mathrm{~Hz})$ cells loaded with Fura-2 $(0.2 \mu \mathrm{M})$. These recordings were made by digital image analysis (SCIL-software [10]) on a DEC-station 5000 (Digital). The fluorescent image of a single cell under $380 \mathrm{~nm}$ excitation was recorded with a CCD-video camera (COHU) equipped with a Delnocta image intensifier (Old Delft). The cell under investigation was positioned horizontally by turning the camera around its axis and was identified by the interactive positioning of a rectangle of variable size closely around it. The image area within this rectangle was digitized on-line with a DASM frame grabber, allowing a time resolution of $60 \mathrm{~ms}$ per frame. Since the fluorescent cell appears as a white object against a black background, the cell can be topographically located within the rectangle on a pixel-by-pixel basis: pixels belonging to the cell have a high intensity, whereas the background pixels have very low intensity (i.e. close to zero). An auto-threshold procedure thus isolates the cell from the background, and allows determination of cell length: the maximal number of highintensity pixels on the horizontal axis is a measure of cell length in a given video frame. A sequence of 5-10 contractions was recorded under each of the experimental 
conditions and the data from these contractions were averaged to determine the cell response. The maximal amplitude of cell shortening was reported as the change in cell length relative to its diastolic length. The mean intensity of the cell pixels reflects the cell fluorescence after $380 \mathrm{~nm}$ excitation (unbound FURA-2) and served as a measure of $\left[\mathrm{Ca}^{2+}\right]_{\mathrm{i}}$. As such the maximal change in $380 \mathrm{~nm}$ fluorescence intensity relative to diastole was representative for the peak of the $\left[\mathrm{Ca}^{2+}\right]_{\mathrm{i}}$ transient. Maximal velocity of changes in cell length and $\left[\mathrm{Ca}^{2+}\right]_{i}$ were calculated from both the length and $\left[\mathrm{Ca}^{2+}\right]_{i}$ signals. Figure 1 illustrates the changes in cell length and $\left[\mathrm{Ca}^{2+}\right]_{i}$ of 2 consecutive cellular contractions. After an equilibration period of $30 \mathrm{sec}$ of stimulation, cell shortening and $\left[\mathrm{Ca}^{2+}\right]_{\mathrm{i}}$-transients upon stimulation were measured in the presence of different $\left[\mathrm{Ca}^{2+}\right]_{0}$, ranging from 1 to $10 \mathrm{mM}$. After the highest $\left[\mathrm{Ca}^{2+}\right]_{0}$, the cells were reincubated in $1 \mathrm{mM}\left[\mathrm{Ca}^{2+}\right]_{\mathrm{e}}$. At two and four min after reinstalling $1 \mathrm{mM}\left[\mathrm{Ca}^{2+}\right]_{e}$, cell shortening and the $\left[\mathrm{Ca}^{2+}\right]_{i}$-transients were measured again. In addition, just before field stimulation the actual resting (i.e. diastolic) cell length was measured in the quiescent cells at every $\left[\mathrm{Ca}^{2+}\right]_{\mathrm{e}}$. The total duration of the experiment was about $30 \mathrm{~min}$ and cells becoming round at any time during the experimental protocol were excluded from analysis. No differences in the number of round cells were observed between both groups ( $20 \%$ of total number of cells used).

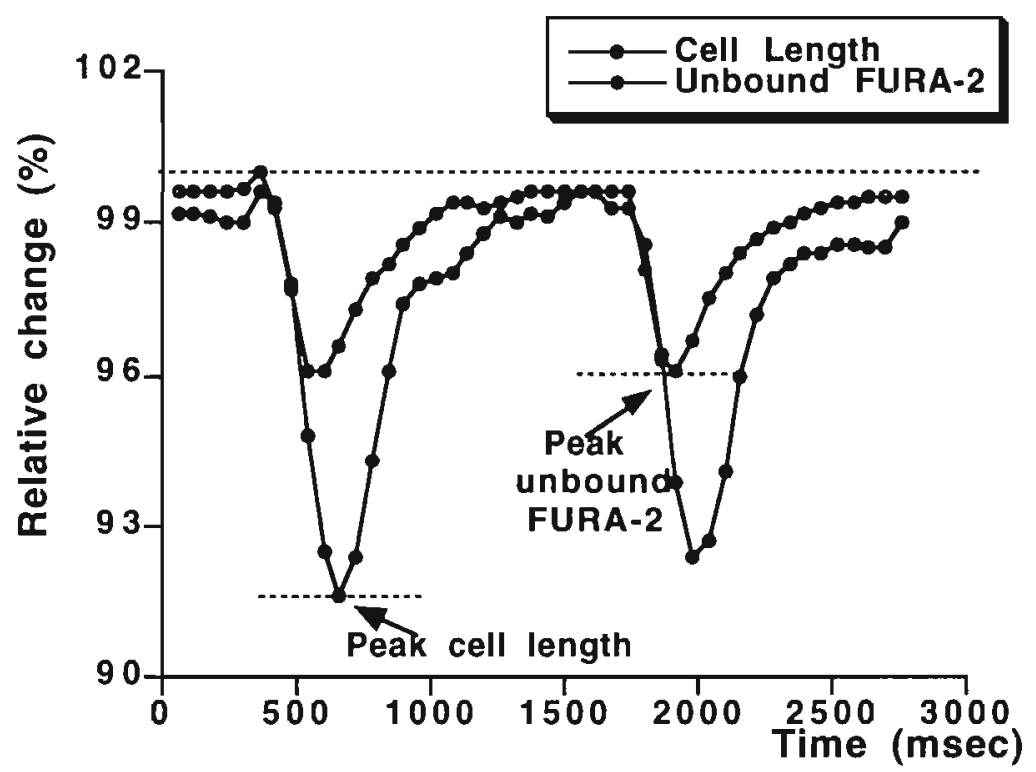

Figure 1: Original tracing of the measurement of changes in cell length and unbound FURA-2, the latter representative for $\left[\mathrm{Ca}^{2+}\right]_{i}$ in a representative cell from a control rat, paced at $0.5 \mathrm{~Hz}$ in $1 \mathrm{mM}\left[\mathrm{Ca}^{2+}\right]_{e}$. The ordinate shows the change in cell length and unbound FURA-2 relative to diastolic levels, respectively. The tracing representative of unbound FURA-2 was obtained by the fluorescence intensity (relative to the diastolic level) at $380 \mathrm{~nm}$ excitation. The arrows indicate the positions where the different parameters were measured. 


\section{Induction of $\mathrm{Ca}^{2+}$ overload}

Intracellular calcium overload in quiescent or electrically paced cells, evidenced by the appearance of hypercontracture and rounding [1], was induced either directly by increasing $\left[\mathrm{Ca}^{2+}\right]_{e}$, or indirectly by using veratridine in combination with increasing $\left[\mathrm{Ca}^{2+}\right]_{\mathrm{e}}$.

Hypercontracture following exposure to increasing $\left[\mathrm{Ca}^{2+}\right]_{e}$ : Separate batches of quiescent heat-shocked and control cardiomyocytes were exposed to $\left[\mathrm{Ca}^{2+}\right]_{e}$ ranging from 0.5 to $20 \mathrm{mM}$ for $15 \mathrm{~min}$. In a second set of experiments separate batches of cardiomyocytes were electrically stimulated for $30 \mathrm{~min}$ at $\left[\mathrm{Ca}^{2+}\right]_{\mathrm{e}}$ between 0.5 and 5 $\mathrm{mM}$. Cardiomyocytes were paced at $2 \mathrm{~Hz}$, using field stimulation with rectangular constant current pulses of $99 \mathrm{~mA}$ and $10 \mathrm{msec}$ duration [1]. The percentage of cells responsive to electrical stimulation at each $\left[\mathrm{Ca}^{2+}\right]_{e}$ was also determined.

Hypercontracture following exposure to veratridine and increasing $\left[\mathrm{Ca}^{2}+\right]_{e}$ : The compound veratridine slows the inactivation of the $\mathrm{Na}^{+}$channel, leading to initial intracellular $\mathrm{Na}^{+}$-overload, followed by $\mathrm{Ca}^{2+}$-overload, due to activation of the $\mathrm{Na}^{+} / \mathrm{Ca}^{2+}$ exchanger [19]. Batches of quiescent cardiomyocytes from heat-shocked and control rats were exposed to various concentrations of veratridine ( 3 to 100 $\mu \mathrm{g} / \mathrm{ml}$ ) for $5 \mathrm{~min}$ at $\left[\mathrm{Ca}^{2+}\right]_{\mathrm{e}}$, ranging from 0.125 to $1.0 \mathrm{mM}$ as described earlier [19].

\section{Reduction of $\mathrm{Ca}^{2+}$ overload by $\mathrm{R} 56865$}

$\mathrm{R} 56865$, a well known $\mathrm{Na}^{+}$-induced $\mathrm{Ca}^{2+}$ overload inhibitor [17; 18], was used to further investigate the properties of the voltage-dependent sodium channels in heat-shocked cardiomyocytes. R 56865 was dissolved in dimethylsulphoxide (10 mM stock solution), acidified with $5 \% \mathrm{v} / \mathrm{v} \mathrm{HCl}(1 \mathrm{~N})$ and diluted to the desired concentration with water. The solvent was diluted accordingly in the control experiments. The drug or drug-free solvent was added $30 \mathrm{~min}$ prior to the start of the experiment. Unless stated otherwise the drug concentration used was $30 \mathrm{nM}$.

\section{Response to electrical field stimulation}

To assess the electrical excitability of cells from heat-shocked compared to control rats, their response to field-stimulation was determined. Two platinum wires $(4 \mathrm{~cm}$ long) were positioned $3.5 \mathrm{~cm}$ apart in petri dishes $(65 \mathrm{~mm}$ diameter) containing $3 \mathrm{ml}$ $\mathrm{KRH}$ plus $1 \mathrm{mM} \mathrm{Ca}^{2+}$. Cells were paced at $2 \mathrm{~Hz}$ with increasing electrical currents (15 to $100 \mathrm{~mA}$ ).

\section{Statistical analysis}

All data are presented as mean values $\pm \mathrm{sd}$. The symbol $\mathrm{n}$ refers to the number of preparations (animals). For all analyses, data were obtained on several individual cells. The results obtained on individual cells from one animal were always pooled and averaged and represent one observation. Mean values were then calculated from the number of preparations. Comparison of differences between heat-shocked and control cardiomyocytes isolated on the same day, was carried out with the Wilcoxon matched-pairs signed ranks test. Comparison of differences within the same cardiomyocyte submitted to various treatments was also evaluated by the Wilcoxon matched-pairs signed ranks test. A p-value of $\leq 0.05$ was considered to be statistically significant. 


\section{RESULTS}

\section{Isolation procedure}

At the end of the isolation procedure cardiomyocytes from heat-shocked hearts were more resistant $(\mathrm{p}=0.04)$ to the isolation procedure than the controls since the percentage rod-shaped (i.e. viable) cells at the end of the procedure was 46tivis in: heat-shocked cells ( $n=11$ rats) compared to $35 \pm 14 \%$ in control cells $(n=11$ rats). Cells. were allowed to recover for approximately one hour before the experiments were performed. Only the rod-shaped cells were used in the experiments.

\section{Steady state FURA-2 fluorescence ratio (i340/i380) in quiescent cells as a function of} $\left[\mathrm{Ca}^{2+}\right]_{\mathrm{e}}$

In 3 batches of cells from heat-shocked and control rats, the FURA-2 fluorescence ratio (i340/i380) in quiescent cardiomyocytes increased equally in both cell types upon exposure to 0.5 to $10 \mathrm{mM}\left[\mathrm{Ca}^{2+}\right]_{e}$ (Figure 2). At $0.5 \mathrm{mM}\left[\mathrm{Ca}^{2+}\right]_{e}$ the $1340 / 1380$ amounted to $0.53 \pm 0.05$ and $0.55 \pm 0.12$ in cells from control and heat-shocked rats; respectively. At the highest $\left[\mathrm{Ca}^{2+}\right]_{\mathrm{e}}$, i.e. $10 \mathrm{mM}$, the $\mathrm{i} 340 / \mathrm{i} 380$ increased to $0.61 \pm 0.06$ and $0.64 \pm 0.13$ in cells from control and heat-shocked rats, respectively.

\section{i340/i380}

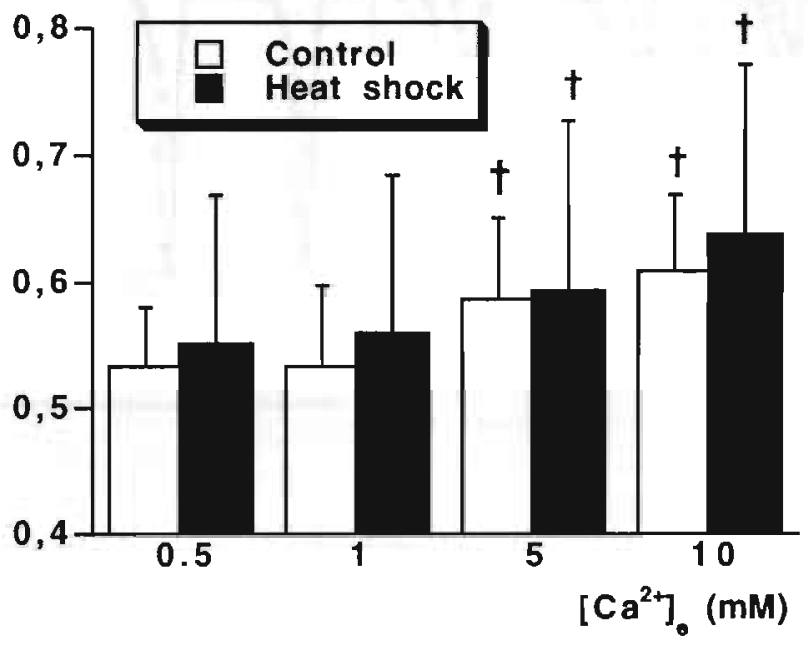

Figure 2: Effects of different extracellular calcium concentrations $\left[\mathrm{Ca}^{2+}\right]_{e}$ on the FURA-2 flouresence ratio (i340/i380) in isolated cardiomyocytes. Data are mean values \pm sd; $n=3$ preparations. Four to nine cells were investigated in each preparation. For precise protocol see explanations in the methods section. $t$ : significantly different from the values at $1 \mathrm{mM}\left[\mathrm{Ca}^{2+}\right]_{e}$.

Effect of electrical stimulation on $\left[\mathrm{Ca}^{2+}\right]_{i}$ and cell shortening at increasing $\left[\mathrm{Ca}^{2+}\right]_{e}$

To determine whether cardiomyocytes from heat-shocked rats had an altered sensitivity of the contractile apparatus to increasing $\left[\mathrm{Ca}^{2+}\right]_{e}$, dynamic intracellular calcium and cell length changes were simultaneously determined in fieldstimulated cardiomyocytes. Figure 3 shows a representative recording of the simultaneous measurement of changes in cell length and intracellular calcium in a $0.5 \mathrm{~Hz}$ paced cardiomyocyte from a control rat. The averaged peak height of both 
parameters in 5 contractions during a $10 \mathrm{sec}$ recording was used to compare maximal changes in unbound FURA-2, representative for $\left[\mathrm{Ca}^{2+}\right]_{i}$, and cell length under the various conditions. The results presented in Figure 4 show that over a broad range of $\left[\mathrm{Ca}^{2+}\right]_{e}$ (1 to $10 \mathrm{mM}$ ), no differences were detectable between cells from control and heat-shocked rats. After 2 and $4 \mathrm{~min}$ upon return to $1 \mathrm{mM}\left[\mathrm{Ca}^{2+}\right]_{\mathrm{e}}$ again no differences in relative cell length change and calcium transients between both cell types could be detected. In contrast, both the calcium transients and cell length changes at $1 \mathrm{mM}\left[\mathrm{Ca}^{2+}\right]_{e}$ after the $10 \mathrm{mM}\left[\mathrm{Ca}^{2+}\right]_{e}$ challenge were significantly higher compared to the initial $1 \mathrm{mM}\left[\mathrm{Ca}^{2+}\right]_{e}$ in cells from heat-shocked and control rats, except for the calcium transient in the hearts from heat-shocked rats four minutes after returning to $1 \mathrm{mM}\left[\mathrm{Ca}^{2+}\right]_{e}$ (Fig 4). It should be emphazised that the relative change in unbound FURA-2 (i380) as reported here, is not linearily correlated with the absolute $\left[\mathrm{Ca}^{2+}\right]_{\mathrm{i}}[10]$. However, the relative cell length changes (upon stimulation) can be interpreted in real terms (i.e., linearily correlated).

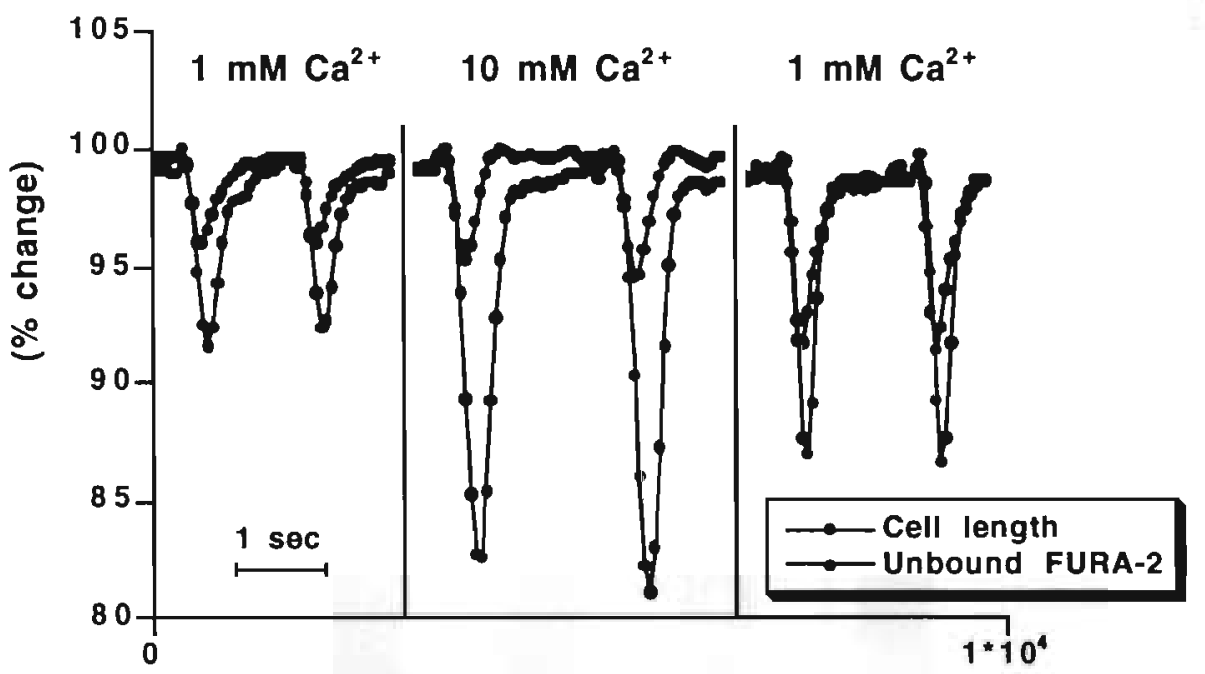

Figure 3 : Original tracing of the measurement of changes in cell length and $\left[\mathrm{Ca}^{2+}\right]_{\mathrm{i}}$ in a representative cell from a control rat, paced at $0.5 \mathrm{~Hz}$, illustrating changes at challenge with $1 \mathrm{mM}\left[\mathrm{Ca}^{2+}\right]_{e}, 10 \mathrm{mM}\left[\mathrm{Ca}^{2+}\right]_{e}$ and back to $1 \mathrm{mM}$ $\left[\mathrm{Ca}^{2+}\right]_{e}$. The ordinate shows the change in cell length and unbound FURA-2 relative to diastolic levels, respectively. The tracing representative of unbound FURA-2 was obtained by the fluorescence intensity at $380 \mathrm{~nm}$ excitation.

At all. $\left[\mathrm{Ca}^{2+}\right]_{\mathrm{e}}$ tested, the mean velocity of changes in cell length as well as the calcium transients (i380 signal) revealed no significant differences between the two groups (Table 1). In contrast, significant differences were observed in cells from heat-shocked and control rats between the mean velocity of changes in cell length at $1 \mathrm{mM}\left[\mathrm{Ca}^{2+}\right]_{\mathrm{e}}$ after the $10 \mathrm{mM}\left[\mathrm{Ca}^{2+}\right]_{\mathrm{e}}$ challenge compared to the initial $1 \mathrm{mM}\left[\mathrm{Ca}^{2+}\right]_{e}$. 

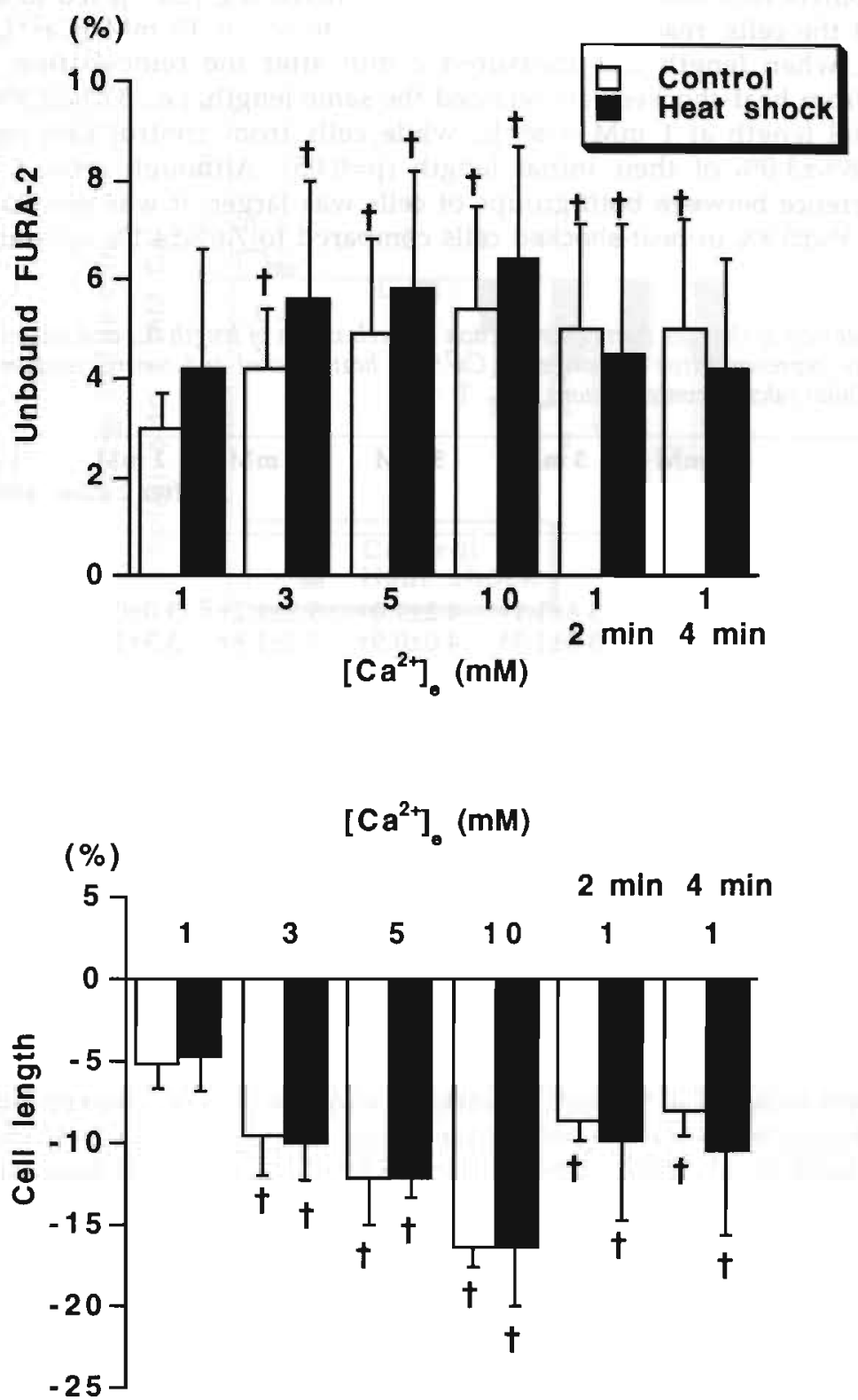

Figure 4: Maximal changes in unbound FURA-2 (upper panel) and cell length (lower panel) related to diastolic values $(100 \%)$ after challenge with different concentrations of $\left[\mathrm{Ca}^{2+}\right]_{\mathrm{e}}$. Celis were electrically stimulated at $0.5 \mathrm{~Hz}$. Data are mean values $\pm \mathrm{sd} ; \mathrm{n}=7$ or 8 preparations per group. The full protocol is described in the methods section. + : significantly different from the values at the initial $\left[\mathrm{Ca}^{2+}\right]_{e}$ of $1 \mathrm{mM}$ (i.e. before $10 \mathrm{mM}\left[\mathrm{Ca}^{2+}\right]_{e}$ challenge). 
The effect of increasing $\left[\mathrm{Ca}^{2+}\right]_{e}$ on resting (i.e. diastolic) cell length was also measured prior to field stimulation. When diastolic cell length in quiescent (nonpaced) cardiomyocytes was taken as a reference, increasing $\left[\mathrm{Ca}^{2+}\right]_{e}$ led to a relative shortening of the cells, reaching a maximum of 4 to $6 \%$ at $10 \mathrm{mM}\left[\mathrm{Ca}^{2+}\right]_{\mathrm{e}}$ (Fig 5). Interestingly, when length was measured $2 \mathrm{~min}$ after the reincubation in $1 \mathrm{mM}$ $\left[\mathrm{Ca}^{2+}\right]_{\mathrm{e}}$ cells from heat-shocked rats retained the same length, i.e., $3.6 \% \pm 1.9 \%$ shorter than the initial length at $1 \mathrm{mM}\left[\mathrm{Ca}^{2+}\right]_{e}$, while cells from control rats contracted further to $6.8 \% \pm 3.0 \%$ of their initial length $(p=0.05)$. Although after $4 \mathrm{~min}$ the absolute difference between both groups of cells was larger, it was not statistically significant $(4.3 \% \pm 0.9 \%$ in heat-shocked cells compared to $7.6 \% \pm 4.1 \%$ in control cells; $\mathrm{p}=0.14)$.

Table 1: Mean velocity of changes during contraction and relaxation of length $(L)$ and unbound FURA2 (Ca) transients, representatitve of changes in $\mathrm{Ca}^{2+}$, in heat shocked and control cardiomyocytes at different extracellular calcium concentrations.

\begin{tabular}{|c|c|c|c|c|c|c|}
\hline$\left[\mathrm{Ca}^{2+}\right]_{e}$ & $1 \mathrm{mM}$ & $3 \mathbf{m M}$ & $5 \mathrm{mM}$ & $10 \mathrm{mM}$ & $\begin{array}{c}1 \mathrm{mM} \\
\text { after } 2 \mathrm{~min}\end{array}$ & $\begin{array}{l}1 \mathrm{mM} \\
\text { after } 4 \mathrm{~min}\end{array}$ \\
\hline \multirow{2}{*}{\multicolumn{7}{|c|}{$+\mathrm{dL} / \mathrm{dt}$}} \\
\hline Control & $2.1 \pm 0.8$ & $3.8 \pm 1.1 \dagger$ & $4.2 \pm 1.0+$ & $5.3 \pm 1.2 \dagger$ & & $3.0 \pm 0.8 \dagger$ \\
\hline Heat shock & $1.8 \pm 0.8$ & $3.3 \pm 1.3+$ & $4.0 \pm 0.9+$ & $5.2+1.8+$ & $3.3 \pm 1.2+$ & $2.8 \pm 1.1+$ \\
\hline \multicolumn{7}{|l|}{$-\mathrm{dL} / \mathrm{dt}$} \\
\hline Control & $1.6 \pm 0.5$ & $2.8 \pm 0.9 t$ & $3.2 \pm 0.8 t$ & $4.1 \pm 0.8 t$ & $2.3 \pm 0.3+$ & $2.2 \pm 0.3+$ \\
\hline Heat shock & $1.3 \pm 0.4$ & $2.6 \pm 0.8+$ & $3.2 \pm 0.6+$ & $4.2 \pm 1.2+$ & $2.6 \pm 1.1 \dagger$ & $2.6 \pm 1.4+$ \\
\hline \multicolumn{7}{|l|}{$+\mathrm{dCa} / \mathrm{dt}$} \\
\hline Control & $1.6 \pm 0.2$ & $1.7 \pm 0.4$ & $1.9 \pm 0.6$ & $2.0 \pm 0.7$ & $1.7 \pm 0.7$ & $1.8 \pm 0.7$ \\
\hline $\begin{array}{l}\text { Heat shock } \\
\text {-dCa/dt }\end{array}$ & $1.9 \pm 0.5$ & $2.0 \pm 0.9$ & $2.1 \pm 0.7$ & $2.2 \pm 1.2$ & $1.7 \pm 1.0$ & $1.6 \pm 1.1$ \\
\hline Control & $0.9 \pm 0.2$ & $1.0 \pm 0.2$ & $1.2+0.3$ & $1.5 \pm 0.2$ & $1.1 \pm 0.3$ & $1.1 \pm 0.3$ \\
\hline Heat shock & $1.1 \pm 0.5$ & $1.4 \pm 0.5$ & $1.5 \pm 0.5$ & $1.7 \pm 0.7$ & $1.1 \pm 0.5$ & $1.0 \pm 0.5$ \\
\hline
\end{tabular}

Data are mean values $\pm s d$, and expressed as $\%$ change. $t$ : significantly different from the values obtained at the initial $\left[\mathrm{Ca}^{2+}\right]_{e}$ of $1 \mathrm{mM}$.

Effect of increasing $\left[\mathrm{Ca}^{2+}\right]_{e}$ and electrical stimulation on morphology and contraction Figure 6 shows the percentage of rod-shaped cells in cells from heatshocked and control rats after $15 \mathrm{~min}$ exposure to $\left[\mathrm{Ca}^{2+}\right]_{\mathrm{e}}$, varying between 1 to 20 $\mathrm{mM}$. At $\left[\mathrm{Ca}^{2+}\right]_{\mathrm{e}}$ between 1 and $5 \mathrm{mM}$ about $70-90 \%$ of the cells remained rod-shaped. At higher concentrations, the number of rod-shaped cells decreased to $30-40 \%$ at 20 $\mathrm{mM}\left[\mathrm{Ca}^{2+}\right]_{\mathrm{e}}$ in both conditions. At all $\left[\mathrm{Ca}^{2+}\right]_{\mathrm{e}}$ tested no significant differences between control and heat-shocked cells were observed. In a separate set of experiments it was investigated whether differences could be observed between both groups after shorter exposures to $\left[\mathrm{Ca}^{2+}\right]_{\mathrm{e}}$. Therefore, the percentage rod-shaped cells was determined after 1, 2, 4 and $8 \mathrm{~min}$ exposure. Again no statistically significant differences were present between both groups (data not shown). These data also revealed that most rounding of cells already occurred during the first $4 \mathrm{~min}$ of exposure to calcium.

After $30 \mathrm{~min}$ stimulation at $2 \mathrm{~Hz}$ and $100 \mathrm{~mA}$ no statistical differences were found in rounding between both groups of cells at $\left[\mathrm{Ca}^{2+}\right]_{\mathrm{e}}$ varying from 0.5 to $5 \mathrm{mM}$ (Figure 7; upper panel). It should be pointed out that at $0.5 \mathrm{mM}\left[\mathrm{Ca}^{2+}\right]_{e}$ only $43 \% \pm 13 \%$ of the heat-shocked cells was contracting compared to $62 \% \pm 13 \%$ of control 
cells $\left(p=0.18 ; n=3\right.$ ) (Figure 7; lower panel). At higher $\left[\mathrm{Ca}^{2+}\right]_{\mathrm{e}}$ at least $90 \%$ of the cardiomyocytes were contracting in both groups of cells.

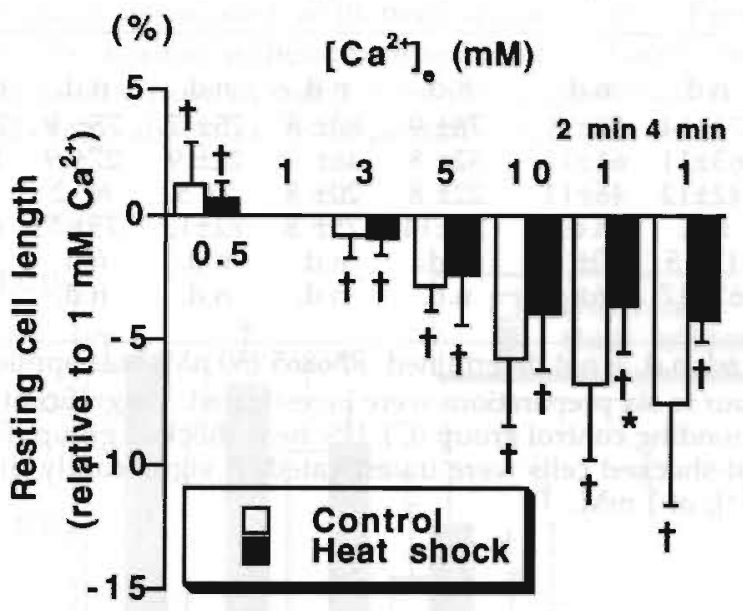

Figure 5: Percentage change in resting cell length relative to the length at $1 \mathrm{mM}$ $\left[\mathrm{Ca}^{2+}\right]_{e}$. The same protocol was followed as in figure 2 . Resting cell length was measured manually just before the electrical stimulation was started. Data are mean values \pm sd; $n=4$ or 5 preparations. *: Significantly different from the values in the corresponding control group. $t$ : significantly different from the values at the initial $\left[\mathrm{Ca}^{2+}\right]_{e}$ of $1 \mathrm{mM}$ (i.e. before $10 \mathrm{mM}\left[\mathrm{Ca}^{2+}\right]_{e}$ challenge).

Cardiomyocytes from heat-shocked and control rats were exposed to various concentrations of veratridine in combination with different $\left[\mathrm{Ca}^{2+}\right]_{e}$ for $5 \mathrm{~min}$ (Table 2). In both groups at all concentrations of veratridine $\left(\left[\mathrm{Ca}^{2+}\right]_{e}=1.0 \mathrm{mM}\right)$, similar percentages of rod-shaped cells were detected, except for the veratridine concentration of $10 \mu \mathrm{g} / \mathrm{ml}$. At this concentration significantly more cells from heatshocked rats were hypercontracted $(p=0.04)$. The sensitivity to veratridine at the various $\left[\mathrm{Ca}^{2+}\right]_{e}$ tested was comparable in both groups. As expected [19], the compound R56865 successfully antagonized the effect of veratridine. This antagonizing effect was comparable in heat-shocked and control cells (Table 2).

To compare the excitability of heat-shocked and control cardiomyocytes under baseline extracellular conditions, i.e. $\left[\mathrm{Ca}^{2+}\right]_{e}=1 \mathrm{mM}$, cells were paced at $2 \mathrm{~Hz}$, while the electrical current was varied between 15 and $100 \mathrm{~mA}$ (Figure 8; upper panel). No differences in the percentage of excitable cells between cardiomyocytes from heatshocked and control rats were observed. Addition of $3 \mu \mathrm{M} \mathrm{R} 56856$ prior to electrical stimulation significantly lowered the excitability of cells from both heat-shocked and control rats and again no differences between cells from heat-shocked and control rats could be detected (Figure 8; lower panel). 
Table 2: Percentage rod-shuped cells upon exposure to increasing veratridine concentrations (with or without the addition of R56865) at different extracellular calcium concentrations.

\begin{tabular}{|c|c|c|c|c|c|c|c|c|}
\hline \multirow{2}{*}{$\begin{array}{c}\left.\qquad \mathrm{Ca}^{2+}\right]_{e} \\
\text { Veratridine }(\mu \mathrm{g} / \mathrm{ml})\end{array}$} & \multicolumn{2}{|c|}{$0.125 \mathrm{mM}$} & \multicolumn{2}{|c|}{$0.25 \mathrm{mM}$} & \multicolumn{2}{|c|}{$0.50 \mathrm{mM}$} & \multicolumn{2}{|c|}{$1.0 \mathrm{mM}$} \\
\hline & $C$ & HS & C & HS & C & HS & C & HS \\
\hline 3 & n.d. & n.d. & n.d. & n.d. & nd. & n.d. & $67 \pm 13$ & $77 \pm 10$ \\
\hline $\begin{array}{l}10 \\
30 \\
50 \\
50(+\mathrm{R} 56865) \\
100 \\
100(+\mathrm{R} 56865)\end{array}$ & $\begin{array}{c}71 \pm 14 \\
63 \pm 11 \\
42 \pm 12 \\
\text { n.d. } \\
17 \pm 5 \\
67 \pm 17\end{array}$ & $\begin{array}{l}76 \pm 8 \\
61 \pm 11 \\
46 \pm 11 \\
\text { n.d. } \\
20 \pm 5 \\
76 \pm 7\end{array}$ & $\begin{array}{l}78 \pm 9 \\
52 \pm 8 \\
22 \pm 8 \\
74 \pm 14 \\
\text { n.d. } \\
\text { n.d. }\end{array}$ & $\begin{array}{l}83 \pm 8 \\
48 \pm 9 \\
20 \pm 8 \\
75 \pm 8 \\
\text { n.d. } \\
\text { n.d. }\end{array}$ & $\begin{array}{l}75 \pm 7 \\
22 \pm 9 \\
3 \pm 5 \\
72 \pm 13 \\
\text { n.d. } \\
\text { n.d. }\end{array}$ & $\begin{array}{l}75 \pm 9 \\
27 \pm 9 \\
6 \pm 2 \\
75 \pm 7 \\
\text { n.d. } \\
\text { n.d. }\end{array}$ & $\begin{array}{l}71 \pm 10 \\
12 \pm 3 \\
3 \pm 1 \\
48 \pm 8 \\
1 \pm 1 \\
\text { n.d. }\end{array}$ & $\begin{array}{c}51 \pm 15^{*} \\
7 \pm 2 \\
2 \pm 1 \\
45 \pm 5 \\
1 \pm 1 \\
\text { n.d. }\end{array}$ \\
\hline
\end{tabular}

Data are mean values \pm sd. $n$.d. $=$ not determined. $R 56865(30 \mathrm{nM})$ was applied 30 min before veratridine challenge. Four to six preparations were investigated. ": significantly different from the values in the corresponding control group (C). HS: heat-shocked group. Five preparations each of control and heat-shocked cells were investigated. $t$ : significantly different from the values at the initial $\left[\mathrm{Ca}^{2+}\right]_{e}$ of $1 \mathrm{mM}$.

\section{DISCUSSION}

The results of the present study indicate that heat shock has no major effects on the intracellular calcium homeostasis in isolated cardiomyocytes 24 hours after heat treatment in vivo. We observed no differences in resting $\left[\mathrm{Ca}^{2+}\right]_{i}$, nor in the dynamics of $\left[\mathrm{Ca}^{2+}\right]_{i}$ handling in excitation-contraction coupling. Furthermore, the increase of intracellular $\mathrm{Ca}^{2+}$ upon challenge with high extracellular $\mathrm{Ca}^{2+}$ was similar in cells from both heat-shocked and control rats. However, after challenge with high $\left[\mathrm{Ca}^{2+}\right]_{\mathrm{e}}$ cells from heat-shocked rats retained their length while cells from control rats hypercontracted further.

The use of isolated cardiomyocytes allows to investigate the intracellular calcium homeostasis after heat shock under controlable experimental conditions. It should be kept in mind, however, that isolated cardiomyocytes as used in the present study are not mechanically loaded. Therefore, the data obtained cannot directly be related to those obtained in the intact heart and thus only reflect the unloaded in situ situation. In this study the approach of in vivo heat stress pretreatment was chosen over the application of heat stress to the cells in culture. We preferred to treat the intact animal so that freshly isolated cells can be utilized in order to avoid interference of unwanted phenomena related to prolonged culturing conditions of cardiomyocytes resulting in phenotypic changes [1] and altered heatshock protein expression. Moreover, it cannot be excluded that cell survival is affected when heat stress is applied under isolated cell conditions [7]. Freshly prepared cardiomyocytes may therefore be more representative of the myocytes in vivo. After hyperthermic treatment, the inducible heat shock protein is expressed in the majority of cardiomyocytes, as previously shown by immunochemistry in intact tissue [16]. It is unknown whether the isolation procedure in itself has affected the functional behavior of the induced heat-shock proteins. To the best of our knowledge, such phenomena have never been described. Since protection against simulated ischemia has been documented in isolated heat-shocked cardiomyocytes [15], the induced heat shock proteins are most likely functionally intact. An interesting observation in the present study was that the yield of rod-shaped cells 
was superior in heat-shocked hearts. Since this difference was observed upon return from very low to $1 \mathrm{mM}\left[\mathrm{Ca}^{2+}\right]$ e during the isolation procedure, it may reflect a better tolerance of cells from heat-shocked rats against the Ca paradox-like condition. [13].

It cannot be excluded that paracrine or other effects through other cell types than myocytes (e.g. from fibroblasts or endothelial cells) play a role in establishing the protective effect associated with heat shock in vivo. Protection of in vivo heatshocked rat hearts against ischemia/reperfusion-induced injury was accompanied by increased coronary flow in our model [5], suggesting that the smooth muscle or endothelial cells may also play an important role.

\section{$(\%)$}

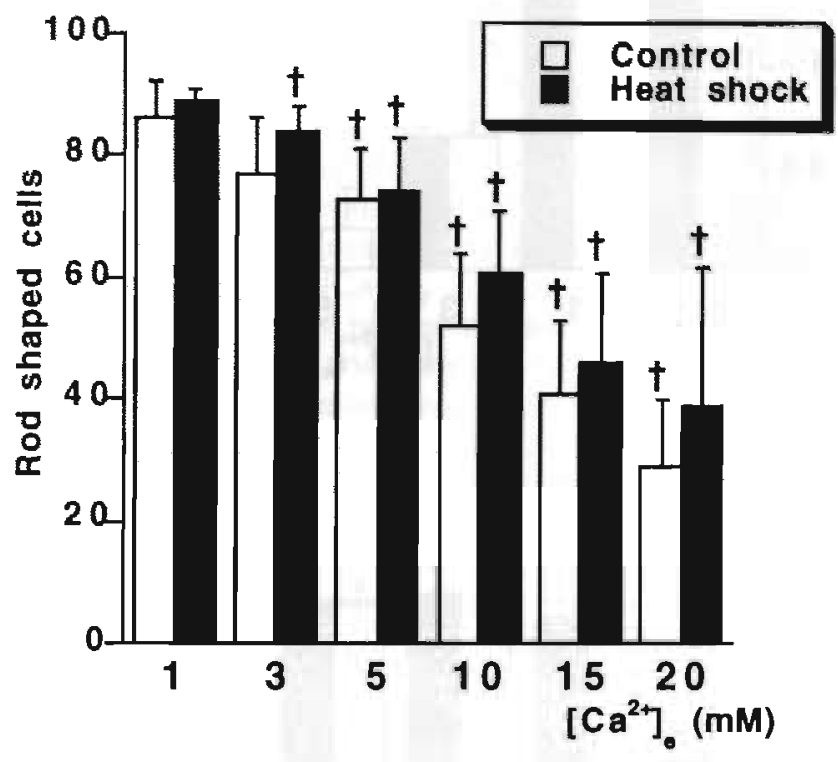

Figure 6: Effects of increasing extracellular calcium concentration $\left(\left[\mathrm{Ca}^{2+}\right]_{e}\right)$ on cell shape of quiescent cardiomyocytes. Data are mean values $\pm s d ; n=5$ preparations. $t$ : significantly different from the values at $1 \mathrm{mM}\left[\mathrm{Ca}^{2+}\right]_{e}$.

In this study we show that the steady state $\left[\mathrm{Ca}^{2+}\right]_{\mathrm{i}}$ (measured by FURA-2 fluorescence ratio (i340/i380)) in quiescent cells from heat-shocked and control cardiomyocytes is identical over a broad range of extracellular calcium concentrations, suggesting that all processes involved in calcium handling are functioning similarly in the heat-shocked and the control cardiomyocyte. Furthermore, exposing either quiescent or paced cardiomyocytes to calcium overload-inducing conditions reveals no differences in hypercontracture development between these cells, suggesting that calcium extrusion and sequestration mechanisms at the level of the sarcolemma are also equally active in cardiomyocytes from heat-shocked and control rats. This is rather unexpected, since it was postulated that cells from heat-shocked rats could better withstand an extracellular calcium challenge, based upon results obtained during reperfusion following ischemia or submaximal calcium paradox $[8 ; 13 ; 23]$. It is therefore tempting to believe that the interference of heat-shock proteins with calcium handling proteins at the level of the sarcolemma is only present during recovery 
Chapter 7

following stressful events, i.e., when the sarcolemmal ion pump mechanisms are disturbed.

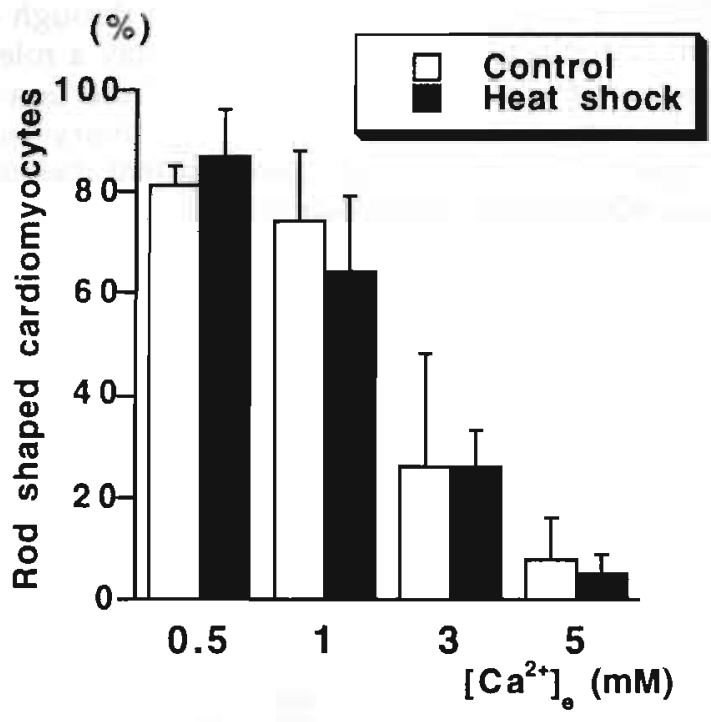

(\%)

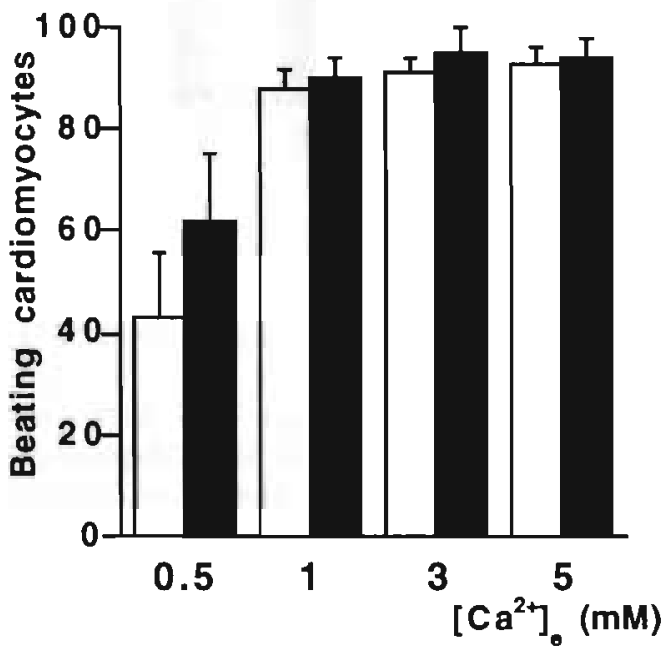

Figure 7: Effects of increasing extracellular calcium concentration $\left(\left[\mathrm{Ca}^{2+}\right]_{\mathrm{e}}\right)$ on cell shape of (upper panel) and excitability (lower panel) in electrically paced cardiomyocytes $(30 \mathrm{~min}$ at $2 \mathrm{~Hz}$ ). Data are mean values $\pm s d ; n=3$ preparations.

Among many direct and indirect cellular mechanisms involved in cellular calcium homeostasis, regulation of intracellular sodium is known to be an impurtant factor. Therefore, we evaluated the sensitivity of the myocytes to veratridine, a toxin that prolongs the inactivation state of the sodium channel, 
leading to a primary intracellular sodium-overload [19]. The similar responsiveness of cardiomyocytes from control and heat shocked rats to a broad range of veratridine. and extracellular calcium concentrations indicates that at least the pharmacological sensitivity of the sodium channels is not affected by heat stress. It also suggests, albeit indirectly that the $\mathrm{Na} / \mathrm{Ca}$-exchanger is not affected by heat shock: the veratridine-induced intracellular sodium-load via the sodium channel, resulted in an equal degree of myocyte hypercontracture (i.e. calcium-overload [19]) via activation of the $\mathrm{Na} / \mathrm{Ca}$-exchanger. That the properties of the voltage-dependent $\mathrm{Na}^{+}$channels are not affected by heat shock is also supported by the similar degree of protection by $\mathrm{R} 56865$, an inhibitor of $\mathrm{Na}^{+}$-induced $\mathrm{Ca}^{2+}$-overload [18]. Furthermore, the level of electrical excitability, depending in part on the activity of $\mathrm{Na}{ }^{+}$-channels and its inhibition by $\mathrm{R} 56865$, is similar in cells from both heatshocked and control rats. Therefore, the present findings do not support the notion that the $\mathrm{Na}^{+}$-channels or sarcolemmal channels, involved in the extrusion of calcium from the cell are altered by heat stress.

The dynamic behavior of the $\left[\mathrm{Ca}^{2+}\right]$ and cell shortening in electrically stimulated cardiomyocytes were also not different in heat-shocked and control rats. The relative systolic $\left[\mathrm{Ca}^{2+}\right]_{\mathrm{i}}$ transient was similar in cells from both heat-shocked and control rats, up to $10 \mathrm{mM}\left[\mathrm{Ca}^{2+}\right]_{\mathrm{e}}$. Two minutes upon return to $1 \mathrm{mM}\left[\mathrm{Ca}^{2+}\right]_{\mathrm{e}}$ after $10 \mathrm{mM}\left[\mathrm{Ca}^{2+}\right]_{\mathrm{e}}$, significantly higher systolic calcium transients were observed in cells from both heat-shocked and control rats compared to the initial calcium transient at $1 \mathrm{mM}\left[\mathrm{Ca}^{2+}\right]_{e}$. However, four minutes upon return to $1 \mathrm{mM}\left[\mathrm{Ca}^{2+}\right]_{e}$, the relative systolic $\left[\mathrm{Ca}^{2+}\right]_{\mathrm{i}}$ transient in heat-shocked cardiomyocytes was not elevated anymore compared to the initial calcium transient at $1 \mathrm{mM}\left[\mathrm{Ca}^{2+}\right]_{\mathrm{e}}$. This indicates that calcium handling normalizes faster in heat-shocked cells compared to control cells.

Since no differences between both heat-shocked and control rats could be detected in the time-related parameters for full contraction and relaxation, it is unlikely that the $\mathrm{Ca}^{2+}$-ATPase activity and the ryanodine-sensitive channels of the sarcoplasmic reticulum are affected in the heat-shocked heart. However, additional investigations are needed to fully exclude possible differences between the sarcoplasmic reticulum (SR)-CaATPase activity and other SR-related calciumhandling proteins in control and heat-shocked cardiomyocytes. The above mentioned findings also indicate that the normal processes involved in excitationcontraction-coupling (e.g. calcium sensitivity for the contractile apparatus) are not affected by heat shock. As such, these results are in agreement with the findings of Kontos et al [12] who did not find significant differences in the $\mathrm{Ca}^{2+}$-pumping ability of SR vesicles isolated from heat-shocked and control hearts.

The finding that the resting (i.e., diastolic) length shortens more in control cells than in heat-shocked cells upon return to $1 \mathrm{mM}\left[\mathrm{Ca}^{2+}\right]_{e}$ after challenge with high $\left[\mathrm{Ca}^{2+}\right]_{e}$ suggests that in the latter cells less $\left[\mathrm{Ca}^{2+}\right]_{i}$ is available during diastole or that the myofilaments are less sensitive to calcium. Under the present experimental conditions, it is impossible to differentiate the effects, if any, on the sarcolemmal, and/or sarcoplasmic reticular site, and on the myofilament sensitivity to calcium. To this end, studies using skinned fibers or permeabilized cells may be helpful in solving this issue. 

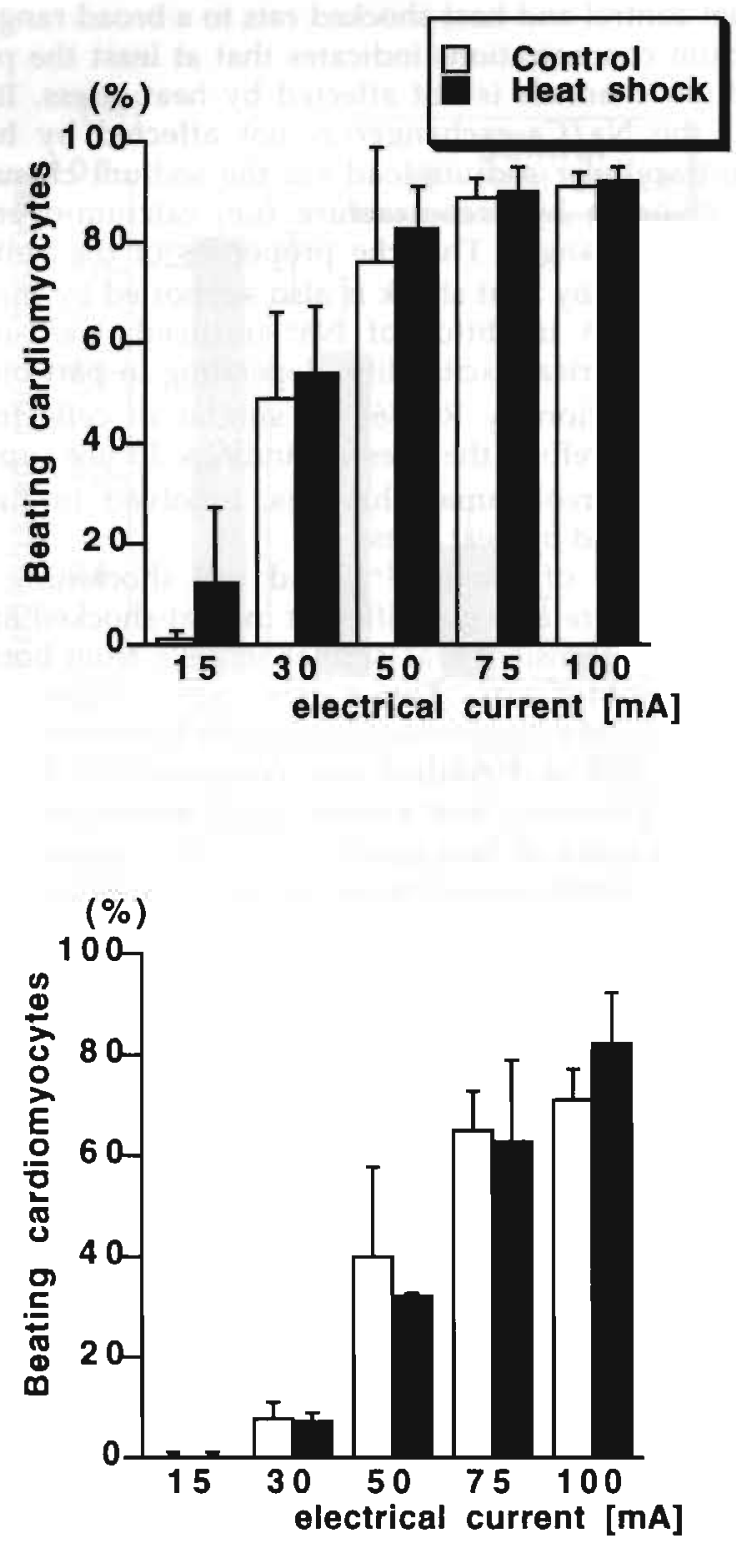

Figure 8: Effect of electrical current in the absence (upper panel) or presence (lower panel) of $30 \mathrm{nM}$ R56865 on the contractile response of cardiomyocytes. Data (\% cells responding to field stimulation) are mean values \pm sd from respectively 5 (upper panel) and 2 (lower panel) preparations per group.

In conclusion, the findings of the present study indicate that the normoxic calcium handling is not grossly altered in cardiomyocytes investigated 24 hours 
after in vivo heat stress. However, subtle changes in "diastolic" rather than "systolic" behavior are observed in heat-shocked cardiomyocytes.

\section{LITERATURE}

1. Borgers, M., L. Ver Donck and G. Vandeplassche. Pathophysiology of cardiomyocytes. Ann N $)^{\circ}$ Acad Sci 522: 433-453, 1988.

2. Brown, J., M. Grosso, L. Terada, G. Whitman, A. Banerjee, C. White, A. Harken and J. Repine. Endotoxin pretreatment increases endogenous myocardial catalase activity and decreases reperfusion injury of isolated rat hearts. Proc Natl Acad Sci USA 86: 2516-2520, 1989.

3. Calderwood, S., M. Stevenson and G. Hahn. Effects of heat on cell calcium and inisotol lipid metabolism. Radiat Res 113: 414-425, 1988.

4. Comelussen, R., L.G. de Bruin, G.J. van der Vusse and L.H.E.H. Snoeckx. Is the post-ischemic heatshock mediated protection of the hypertrophied rat heart perfusion pressure dependent? In: $\mathrm{XV}$ European Section Meeting of International Society for Heart Research. Edited by Hanso S, Kjeldsen K. Bologna, Italy, Monduzzi Editore, 1994, p. 559-563.

5. Cornelussen, R., W. Spiering, J.H.G. Webers, L.G. de Bruin, RS.. Reneman, G.J. van der Vusse and L.H.E.H. Snoeckx. Heat shock improves the ischemic tolerance of the hypertrophied rat heart. Am I Physiol 267: H1941-H1947, 1994.

6. Comelussen, R., G.J. van der Vusse, R.S Reneman and L.H.E.H. Snoeckx. Inability of the heatshocked to adjust its performance preischemic and post-ischemic performance to variable loading conditions. I Mol Cell Cardiol, 28: 291-298, 1996.

7. Crête, P., J. Landry. Induction of HSP27 phosphorylation and thermoresistence in Chinese Hamster cells by arsenite, cycloheximide, A23187 and EGTA. Radiat Res 121: 320-327, 1990.

8. Currie, R.W., M. Karmazyn, M. Kloc and K. Mailer. Heat-shock response is associated with enhanced post-ischemic recovery. Circ Res 63: 543-549, 1988.

9. Donnelly, T., R. Sievers, F. Vissern, W.J. Welch and C.L. Wolfe. Heat-shock protein induction in rat hearts. A role for improved myocardial salvage after ischemia and reperfusion. Circulation 85: 769-778, 1991.

10. Geerts, H., R. Nuydens, R. Nuyens and L. Ver Donck. The effect of flunarizine on intracellular calcium in isolated rat cardiomyocytes. A digital image processing study. Cardiovasc Res 23: 797806, 1989.

11. Heads, R., D.S. Latchman and D.M. Yellon. Stable high level expression of a transfected human HSP70 gene protects a heart-derived muscle cell line against thermal stress. J Mol Cell Cardiol 26: 695-699, 1994.

12. Kontos, M., J. Shipley and R. Kukreja. Heat stress improves functional recovery and induces heat shock protein synthesis without preserving sarcoplasmic reticulum function in the ischemic rat heart. (abstract). I Mol Cell Cardiol 27: A17, 1995.

13. Marber, M.S., J.M. Walker, D.S. Latchman and D.M. Yellon. Attenuation by heat stress of a submaximal calcium paradox in the rabbit heart. J Mol Cell Cardiol 25: 1119-1126, 1993.

14. Maulik, N., Z. Wei, X. Liu, R. Engelman, J. Rousou and D. Das. Improved postischemic ventricular functional recovery by amphetamine is linked with its ability to induce heat shock. Mol Cell Biochem 137: 17-24, 1994.

15. Mestril, R, S. Chi, M. Sayen, K. O'Reilly and W. Dillmann. Expression of inducible stress protein 70 in rat heart myogenic cells confers protection against simulated ischemia-induced injury. J Clin Invest 93: 759-767, 1994.

16. Snoeckx, L.H.E.H., F. Contard, J.-L. Samuel, F. Marotte and L. Rappaport. Expression and cellular distribution of heat-shock and nuclear proteins in rat hearts. Am / Physiol 263: H1443-H1451, 1991.

17. Ver Donck, L. and M. Borgers. R56865, a new cardioprotective principle based on prevention of ion channel pathology. In: Ionic Currents and Ischemia, edited by Vereecke J, Van Bogaert P.P., Verdonck F. Leuven, Belgium: Leuven University press, 1990 p. 304-306.

18. Ver Donck, L. and M. Borgers. Myocardial protection by R56865: a new principle based on prevention of ion channel pathology. Am / Physiol 261: H1828-H1835, 1991.

19. Ver Donck, L., P. Pauwels, G. Vandeplassche and M. Borgers. Isolated rat cardiac myocytes as an experimental model to study $\mathrm{Ca}^{2+}$-overload: the effect of $\mathrm{Ca}^{2+}$-antagonists. Life Sci 38: 765-772, 1986. 
20. Ver Donck, L., G. Verellen, H. Geerts and M. Borgers. Lysophosphatidylcholine-induced $\mathrm{Ca}^{2} \div$ overload in isolated cardiomyocytes and effect of cytoprotective drugs. / Mol Cell Cardiol 24: 977$988,1992$.

21. Wall, S., H. Fliss and B. Korecky. Role of catalase in myocardial protection against ischemia in heat-shocked rats. Mol Cell Biochem 129: 187-194, 1993.

22. Yamamoto, N., M. Smith, A. Maki, I. Berezesky and B. Trump. Role of cytosolic $\mathrm{Ca}^{2+}$ and protein kinases in the induction of the hsp70 gene. Kidney Int 45: 1093-1104, 1994.

23. Yellon, D.M., E. Pasini, A. Cargnoni, M.S. Marber, D.S. Latchman and R. Ferrari. The protective role of heat stress in the ischaemic and reperfused rabbit myocardium. J Mol Cell Cardiol 24: 895$907,1992$. 
Chapter 8

GENERAL DISCUSSION 
During the last decade heat stress preconditioning has been recognized to induce protection against subsequent stresses, such as cardiac ischemia. There is increasing evidence that postischemic cardiac dysfunction during reperfusion after an ischemic insult can be significantly improved and that infarct size can be limited after hyperthermic pretreatment (for review see [43]). It has been shown that the inducible member of the heat stress protein family with a molecular mass of $70 \mathrm{kDa}$, i.e., HSP72, is involved in this myocardial protection $[16 ; 20 ; 29]$. These studies on the cardioprotective effect of this protein were mainly performed on normal adult hearts. Therefore, the present thesis was designed to explore to which extent heat stress pretreatment conferred cardioprotection in hearts known to be more susceptible to ischemic injury, like the hypertrophied and aged heart, than the normal adult heart. Using the rat heart as an experimental model, it was shown in this thesis that both the young adult hypertrophied and the aged hypertrophied heart, as well as the age-matched normal hearts could be protected against an ischemic insult by in vivo hyperthermic pretreatment of the animal twenty-four hours earlier. Postischemically, all hemodynamic variables investigated, i.e., cardiac output, left ventricular developed pressure, contractility and relaxation in pretreated hearts were significantly improved compared to non-pretreated control hearts. To obtain better insight into the nature of the observed cardioprotection, the time-interval between heat pretreatment and postischemic recovery was studied, as well as the dependency of preischemic and postischemic cardiac function on the extracellular calcium concentration and on the afterload imposed on the left ventricle. The results of those studies showed that no cardioprotection was observed when the time-interval between heat pretreatment and the ischemic period was six hours or less. Postischemic cardiac function of heat-shocked hearts investigated at a time-interval of thirty minutes after the hyperthermic pretreatment was even depressed compared to the non-heated heart. Also, low extracellular calcium concentrations and high afterload negatively affected the normoxic preischemic and postischemic cardiac function in hyperthermically pretreated hearts. Therefore, in an attempt to evaluate intracellular calcium homeostasis following heat pretreatment, calcium transients were investigated in cardiomyocytes, isolated from rat hearts twenty-four hours after hyperthermic treatment. The results of this study showed that the calcium handling in unloaded heat-shocked cells was not altered compared to non-pretreated cells.

\section{Limitations of the experimental model}

In this thesis cardiac protection following hyperthermic pretreatment was considered to be present when (1) postischemic left ventricular contractile performance, as assessed by measuring cardiac output, developed pressure and positive $\mathrm{dP} / \mathrm{dt}_{\max }$ was improved; (2) postischemic coronary flow distribution in the left ventricular wall had become more homogeneous; (3) the duration of postischemic arrhythmias was diminished, and (4) postischemic release of cardiac cytosolic enzymes into the coronary effluent was reduced. Although the first three criteria were fulfilled under all experimental circumstances, the fourth criterion was not met in all experiments. It is not clear why in some experiments, in which significant improvement of postischemic left ventricular function was found, the loss of intracellular enzymes was not reduced. The presence of the no-reflow phenomenon in some regions of the non-pretreated heart may limit the loss of enzymes into the coronary effluent [39], leading to a false-positive result in the 
control heart. This complicates the interpretation of the enzyme loss in the pretreated heart.

Otherwise, it could be argued that no differences exist in the degree of irreversible damage, and thus enzyme release, in pretreated and non-pretreated hearts and that the better functional recovery is due to less myocardial stunning in the pretreated heart. Although it has been suggested that hyperthermic pretreatment accelerates the recovery of the postischemic stunned myocardium [31], the experimental model of global ischemia used does not allow to separate irreversible injury from stunning. Moreover, since postischemic cardiac function was only studied during a relatively short time of reperfusion, it is unknown whether the protective effect of hyperthermic pretreatment persists over a longer time period.

The isolated hearts used in the present studies were all perfused with a crystalloid buffer solution which, per definition, results in an almost absent colloid osmotic pressure in the coronary vessels and a reduced oxygen carrying capacity to the heart. Therefore, it can not be excluded that edema formation interfered negatively with cardiac function and that the effects of blood factors, generated by hyperthermic pretreatment in the blood compartment or in other organs, on postischemic cardiac function [43] were lacking.

\section{Possible factors involved in the ischemia tolerance by heat stress pretreatment}

\section{Alteration in vascular response of heat-shocked hearts}

One of the striking findings in the heat-shocked hearts investigated was the significant elevation of coronary flow. Besides, heat shock pretreatment beneficially affected the postischemic distribution of coronary flow towards the subendocardial layers of the left ventricle, especially in the hypertrophied heart, in which the subendocardial underperfusion is more pronounced. At the present state of the art improved subendocardial blood flow may provide a good explanation for the cardiac protection following heat shock. As stated earlier (see Chapters 2 and 4), the origin of this coronary flow increase after heat shock is largely unknown. That enhanced coronary flow is a non-specific phenomenon due to the procedure of heat shock itself is unlikely, because it is also observed in transgenic animals with a constitutive overexpression of HSP72 [29]. Thus coronary flow enhancement is most probably a consequence of the presence of the HSP72 protein in the cardiac tissue. However, the nature of this vasodilation is at present unknown. Probably, the formation of adenosine or nitric oxide, two well known vasodilators, is not in play. This is exemplified by experiments in which coronary flow was increased pharmacologically, by a bolus injection of a mixture of adenosine and nitroprusside [27]. The effects of this vasodilatation on postischemic cardiac recovery was compared with those after heat shock. As can be seen in figure 1 both heat pretreatment and bolus injection of a mixture of adenosine and nitroprusside led to a comparable increase of coronary flow of about $30 \%$ compared to non-treated hearts. After an identical ischemic period, the recovery of cardiac output was significantly improved only in the heat-shocked hearts. Furthermore, the bolus injection of adenosine and nitroprusside in heat-shocked hearts led to a further increase in coronary flow up to $153 \%$ of the values in the control hearts, but no additional beneficial effect on the postischemic cardiac output recovery was found.

Two possible conclusions can be derived from these observations. The first is that coronary vasodilation is not the major mechanism behind heat shock- 
mediated cardioprotection because improvement of postischemic function is absent in hearts in which coronary flow is increased to the same extent via infusion of coronary vasodilators. This notion might be supported by the observation (presented in Chapter 7) that the degree of postischemic recovery three hours after heat pretreatment was not significantly different from control hearts, although postischemic coronary flow was significantly higher in the heat-shocked hearts. It cannot be excluded, however, that the protective effects of hyperthermic pretreatment are absent during the first hours following pretreatment due to a time-dependent, as yet not identified negative factor.

The second conclusion is that the improved recovery of heat-shocked hearts is indeed related to enhanced coronary flow, but that this flow enhancement, compared to the pharmacologically vasodilated hearts, may be distributed more homogeneously throughout the left ventricular wall. The identification of this specific vasodilatory mechanism and the identification of postischemic underperfusion in the endocardium in pharmacologically vasodilated hearts are indispensible to elucidate the role of coronary vasodilation in heat shock-mediated cardioprotection.

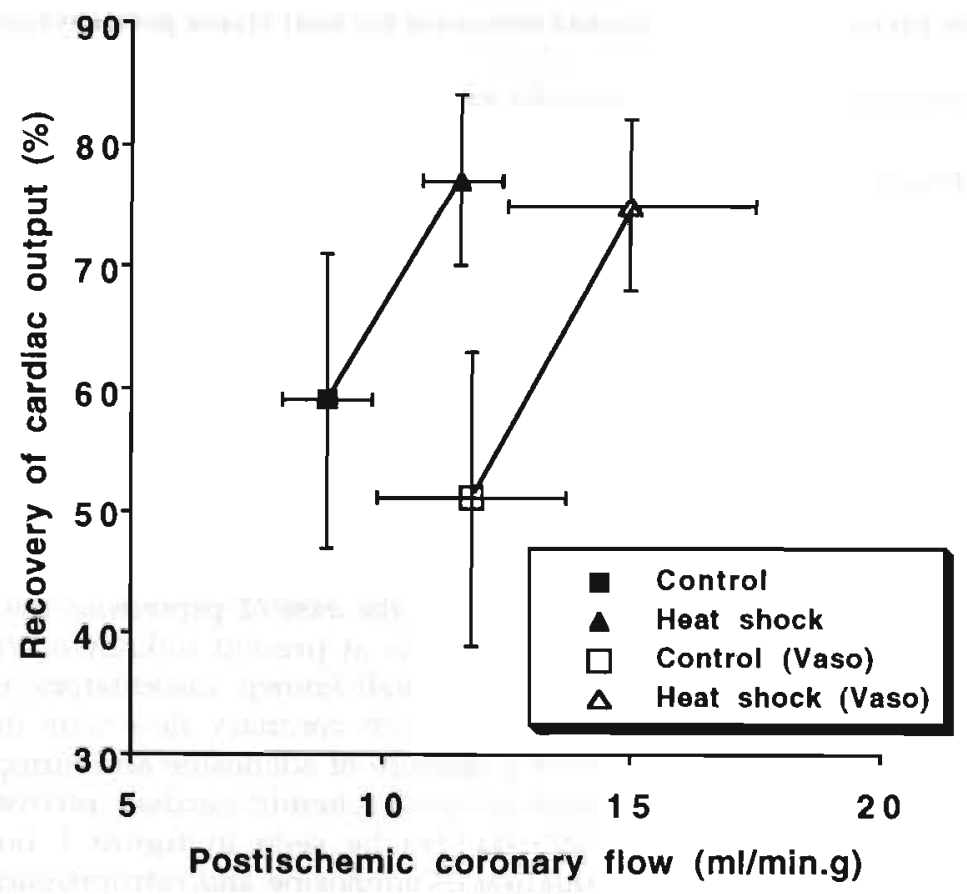

Figure 1: The relation between coronary flow and percentage postischemic recovery of cardiac output in control $(n=12)$, adenosine and nitroprussidetreated (Control-vaso; $n=6)$, heat-shocked $(n=12)$ and adenosine and nitroprusside-treated, heat-shocked hearts (Heat shock-vaso; $n=6$ ). Broken lines indicate the transition from non-heat-shocked to heat-shocked hearts. Data are expressed as mean \pm sd. Administration of adenosine and nitroprusside consisted of a bolus injection of $0.5 \mathrm{ml}$ of adenosine and nitroprusside (both 1 $\mathrm{mmol} / \mathrm{l})$. 
In this thesis and in other studies it has been shown that heat shock increases the endogenous cardiac activity of catalase, the enzyme which is involved in the detoxification of hydrogen peroxyde $[7 ; 8 ; 38 ; 44]$. Initially, this enzyme was believed to play a critical role in heat shock-mediated cardioprotection since its inactivation with 3-aminotriazole resulted in the abolition of the protection [17]. This finding, however, could not be confirmed by others [2, 3,40]. Moreover, increased activity of endogenous catalase seems not be a universal finding in hearts with enhanced levels of the HSP72 protein. For instance, in the hypertrophied hearts investigated in the present thesis we could not document a significantly increased catalase activity, although cardioprotection was clearly present (see Chapter 2). In transgenic mice with constitutively high levels of HSP72 and improved postischemic contractile performance, catalase activity was also not found to be different from that in control hearts [29]. Although the hypothesis of activation of the oxygen free radical system is a very attractive one, there is increasing evidence that this pathway does not play a major role in heat shock-mediated cardioprotection.

\section{Altered calcium homeostasis in heat-shocked hearts}

The finding that low extracellular calcium concentrations and high afterload levels were associated with a depressed contractile function of the heat-shocked heart (see Chapter 6) could lead to the hypothesis that the intracellular calcium homeostasis is affected in this type of heart, and that eventually the cardioprotective effect is a consequence of altered intracellular calcium handling, a possibility supported by indirect evidence published in literature [23; 44]. For instance, the postischemic accumulation of calcium in mitochondria, which is interpreted as a mechanism to reduce the cytosolic overload of this ion in case of an ischemic insult, was found to be significantly reduced in the heat-shocked heart [44]. In another experimental setup, the resistance towards a submaximal calcium paradox was found to be significantly increased in the heat-shocked heart [23]. Therefore, it was decided to study in more detail the calcium handling in cardiomyocytes, isolated from the heart twenty-four hours after heat shock, the time at which the cardioprotective effect is present (see Chapter 7). In these experiments, however, no conclusive evidence could be found that the calcium handling was affected in these cells compared to non-treated cells. It should be pointed out that the cardiomyocytes were mechanically unloaded and isolated from their normal environment such as extracellular matrix and other cells like endothelial cells, smooth muscle cells and fibroblasts. It is recognized that the contractile performance in relation to calcium handling is a result of very complex processes, which involve among others sarcolemmal ion transport, sarcoplasmic reticular calcium transport and calcium sensitivity at the level of the contractile apparatus, and that the study of each of these components, leading to the ultimate contraction pattern, requires specific experimental investigations. In this respect it should be noted that other investigations did not find differences between the sarcoplasmic reticular calcium pump activity in heat-shocked and non-treated hearts [19] and that the improved contractile performance of isolated papillary muscles of heat-shocked hearts was not associated with alterations in myocardial calcium handling, as indicated by a similar force-frequency relationship [24]. So, more studies are needed to fully elucidate the specific role of calcium ions in the heat-shocked heart. Among others, contractile 
performance should be studied in skinned fibers under various loading conditions and different calcium concentrations.

\section{The role of heat shock proteins}

Since at this moment none of the above described mechanisms provide a feasible explanation for the cardioprotective effects of heat shock-mediated cardioprotection, the most forwarded and acccepted hypothesis is that heat shock proteins themselves are responsible for the protective effect. Most of the attention has been paid to the inducible heat shock proteins, particularly the inducible HSP72. There is indeed overwhelming evidence that the presence of this protein is indispensible for the cardioprotective effect. The most convincing evidence has been provided in transgenic mice, overexpressing HSP72 [20; 29]. It can be questioned, however, whether HSP72 is the sole protein responsible for the protective effect. First of all, it has to be emphasized that after heat pretreatment other heat shock proteins may be involved in the protective action. For example, it is known that, like the inducible HSP72 protein, the constitutively expressed heat shock protein HSP73 is redistributed to the nucleus after heat pretreatment [41]. The precise meaning of this redistribution is at present unknown, but it has been shown that HSP73 is involved in the recovery of the structure and function of the centrosome after heat pretreatment [6]. So, it can not be excluded that this redistribution has significance for cardioprotection. This also accounts for other heat shock proteins, which are either upregulated and/or redistributed [4]. Secondly, the overexpression of HSP72 in transgenic mice could activate other proteins and/or processes ultimately leading to protection against ischemia. For instance, it has been shown that overexpression of HSP72 in isolated cells has secondary effects on normal cellular functioning, such as growth [32]. Thirdly, it remains to be proven that specific inhibition of the expression of HSP72 leads to the loss of the cardioprotective effect. Thermotolerance was found to be lost when anti-HSP72 antibodies were injected [30], but no such experiments have been performed regarding the cardioprotective effect of HSP72 against ischemia.

The generally accepted function of HSP72 in the ischemic cell is to bind proteins which have lost their normal tertiary structure due to ischemia-induced denaturation [5]. Due to this binding HSP72 stabilizes these proteins and facilitates their renaturation or rapid degradation during reperfusion, thereby enhancing cell viability [14]. In this respect it is important to realize that the transcription of the HSP72 gene is an early event, leading to significantly elevated HSP72 mRNA levels within three hours after heat shock (see Chapter 7) and to a maximal concentration of the protein within six hours following treatment $[9 ; 11]$. Although at this time the HSP72 protein is present in the tissue in comparable amounts to that found twenty-four hours after pretreatment, the cardioprotective effect is absent (see Chapter 7). It is known that immediately upon synthesis the protein migrates to the nucleus, more specifically to the nucleolus $[37 ; 41]$. It is assumed that the protein binds to ribonucleolar protein complexes [42]. Later the protein is leaking back to the cytosol so that twenty-four hours after heat pretreatment it can be localized in that compartment $[26 ; 28 ; 41]$.

If protection against an ischemic insult is related to the time-dependent translocalization of HSP72, two possible hypotheses could be forwarded for the working mechanism of HSP72-mediated cardioprotection. Based upon observations in prokaryotic organisms [33; 35] it could be proposed that in eukaryotic cells the 
HSP72 protein migrates to the nucleolar region and binds to the polymerase I enzyme, which is the key enzyme for ribosomal RNA transcription. Binding of HSP72 to this enzyme or other proteins involved in ribosomal synthesis could be held responsible for the recovery of protein translation during the first hours after heat shock. In a later phase, i.e., twenty-four hours after the initial heat shock, a second stress such as ischemia, leads to immediate protection of the ribosomal. synthesis machinery or protein translational processes, due to the presence of large amounts of the HSP72 protein in the immediate vicinity of these structures. However, at present it is unknown whether de novo synthesis of proteins is already present within minutes after the ischemic period, a time at which myocardial protection is already observed.

In the second hypothesis the protective effect of HSP72 is due to binding to and stabilization of proteins, present only in the cytosol. Since HSP72 is only present in the nucleolar region within the first six hours following heat shock, this could explain why the protective effect is absent within this period. Because HSP72 is redistributed to the cytosol in a later phase, the protective effect can only be evidenced at that time.

Since it is known that the total amount of induced HSP72 is probably not higher than $0.3 \%$ of the total intracellular protein content [15; 34], HSP72 is unable to bind to all cellular proteins which are denatured. Therefore, it is assumed that HSP72 exerts its protective effect through binding of specific proteins. Indications for a specific target binding of heat shock proteins can be found in the results of Barbato and coworkers [4] which show a complete mobilization during the late-ischemic and postischemic phase of aB-crystallin -another, small heat shock protein- from the cytosol to the myofibrills.

The ultimate proof for these hypotheses must come from the investigation of the time-dependent localization, and binding of HSP72 with target proteins and the effects of this binding on the activity of proteins and enzyme systems.

\section{Windows of heat shock-mediated cardioprotection}

Under experimental circumstances, the protection of the heart against ischemia and reperfusion by hyperthermic pretreatment seems to be a general phenomenun because enhanced postischemic cardiac performance can be observed in a variety of experimental protocols. Hyperthermic pretreatment has been shown to protect the heart in vitro, either retrogradely or antegradely perfused (present thesis) $[1 ; 8 ; 10]$, and the heart in vivo $[13 ; 16]$. There are, however, circumstances under which the beneficial effects are absent. Firstly, the present work (see Chapter 3) and that of others showed that the degree of cardioprotection offered by heat pretreatment is dependent on the duration of the ischemic period. For instance, heat shockmediated cardioprotection was absent in the in vitro perfused heart when the duration of the ischemic episode was too short $[36 ; 40]$ and in the heart in vivo when the ischemic period was too long $[12 ; 13 ; 22 ; 45]$. Secondly, the postischemic afterload level imposed on the pretreated heart seems to be of critical importance (see Chapters 2, 3 and 6). Indeed, it was found that the beneficial effects of hyperthermic pretreatment were only present in hearts ejecting against relatively low afterload levels. An explanation for this afterload-dependency can as yet not be presented. Depressed contractile function of the heat-shocked heart at high afterload could be a consequence of decreased recruitment of calcium-ions from intracellular stores or from disturbed interaction of calcium ions with the contractile proteins. Indications were found for such a disturbed calcium sensitivity for the contractile 
proteins because both under preischemic and postischemic conditions left ventricular pump performance was depressed when the extracellular calcium concentration was low (see Chapter 6). Finally, it was found that the degree of heat stress-mediated cardioprotection was also dependent on the time-lag between hyperthermic pretreatment and the ischemic insult. A cardioprotective effect was only observed twenty-four hours after heat shock. The lack of protection within the first six hours after pretreatment can not be explained by the absence of the HSP72 protein in the cardiac tissue because the protein can already be detected within one hour after heat stress and reaches maximal levels at six hours after hyperthermic pretreatment $[11 ; 18 ; 25 ; 37]$. As such these results indicate that a discrepancy is present between the moment of maximal accumulation of the HSP72 protein and the occurrence of an improvement of ischemia tolerance, despite the fact that twenty-four hours after hyperthermic pretreatment a good correlation is found between both $[16,21]$. It can not be excluded that during the early phase after hyperthermic pretreatment the positive effects are overruled by a not yet identified negative event.

\section{Future directions}

The experimental results of this thesis have led to several new questions which have to be answered the upcoming years.

- Identification of the vasodilatory mechanism, and the study of specific blockade of the different coronary vasodilatory routes in relation to the effects on postischemic functional recovery in heat-shocked hearts.

- Detailed immunohistochemical localisation and quantification of HSP72 in relation to the induced cardioprotection after hyperthermic pretreatment, binding of HSP72 with target proteins and the effects of this binding on the activity of proteins and enzyme systems. Specific deletions or mutations of the HSP72 protein preventing its intracellular redistribution pattern will be helpful in evaluating the importance of translocation of the HSP72 protein for the cardioprotection.

- Detailed study of the calcium homeostasis in relation to contraction pattern in isolated cardiomyocytes with constitutively high levels of HSP72.

- The role of other HSPs than HSP72 in the cardioprotection against an ischemic insult has not been defined. More detailed studies of the time-course of the expression and localisation of these HSPs in relation to the expression and localisation of HSP72/HSP73 are indicated.

- Investigation of the profound antiarrhythmic effect of hyperthermic pretreatment during the postischemic phase.

- Studies on the effects of HSP72 on the activity of isolated enzymes such as RNA polymerase I, on the synthesis of ribosomal structures, and on the stability of cytosolic proteins.

- Investigation of the clinical applicability of heat shock-mediated cardioprotection since at presence it remains to be seen to which extent heat shock proteins can be induced in the normal and compromised human heart. 


\section{LITERATURE}

1. Amrani, M., J. Corbett, N.J. Allen, J. O'Shea, S.Y. Boateng, M.J. Dunn, and M.H. Yacoub. Induction of heat-shock proteins enhances myocardial and endothelial functional recovery after prolonged cardioplegic arrest. Ann Thorac Surg 57: 157-160, 1994.

2. Amrani, M., J. O'Shea, J. Corbett, M.J. Dunn, S. Tadjkarimi, S. Theodoropoulos, J. Pepper, and $\mathrm{MH}$. Yacoub. Role of catalase and heat shock protein on recovery of cardiac endothelial and mechanical function after ischemia. Cardioscience 4: 193-198, 1993.

3. Auyeung, Y., R.E. Sievers, D. Weng, V. Barbosa, and C.L. Wolfe. Catalase inhibition with 3amino-1,2,4-triazole does not abolish infarct size reduction in heat-shocked rats. Circ 92: 3318$3322,1995$.

4. Barbato, R., M. Menabo, P. Dainese, E. Carafoli, S. Schiaffino, and F. Di Lisa. Binding of cytosolic proteins to myofibrils in ischemic rat hearts. Circ Res 78: 821-828, 1996.

5. Beckmann, R.P., M. Lovett, and W.J. Welch. Examining the function and regulation of HSP 70 in cells subjected to metabolic stress. J Biol Chem 117: 1137-1150, 1992.

6. Brown, C.R., L.Q. Hong-Brown, S.J. Doxsey, and W.J. Welch. Molecular chaperones and the centrosome. A role for HSP73 in centrosomal repair following heat shock treatment. / Biol Chem 271: 833-840, 1996.

7. Cornelussen, R., W. Spiering, J.H.G. Webers, L.G.A. de Bruin, R.S. Reneman, G.J. van der Vusse, and L.H.E.H. Snoeckx. Heat shock improves the ischemic tolerance of the hypertrophied rat heart. Am / Physiol 267: H1941-H1947, 1994.

8. Currie, R.W., M. Karmazyn, M. Kloc, and K. Mailer. Heat-shock response is associated with enhanced post-ischemic recovery. Circ Res 63: 543-549, 1988.

9. Currie, R.W., and F.P. White. Characterization of the synthesis and accumulation of a 71kilodalton protein induced in rat tissues after hyperthermia. Can / Biochem Cell Biol 61: 438$446,1983$.

10. Currie, R.W., and M. Karmazyn. Improved post-ischemic ventricular recovery in the absence of changes in energy metabolism in working rat hearts following heat-shock. / Mol Cell Cardiol 22: $631-6,1990$

11. Currie, R.W., and R.M. Tanguay. Analysis of RNA for transcripts for catalase and SP71 in rat hearts after in vivo hyperthermia. Biochem Cell Biol 69: 375-82, 1991.

12. Currie, R.W., R.M. Tanguay, and J.G. Jr Kingma. Heat-shock response and limitation of tissue necrosis during occlusion/reperfusion in rabbit hearts. Circulation 87: 963-71, 1993.

13. Donnelly, T.J., R.E. Sievers, F.L. Vissem, W.J. Welch, and C.L. Wolfe. Heat-shock protein induction in rat hearts. A role for improved myocardial salvage after ischemia and reperfusion. Circulation 85: 769-778, 1992.

14. Georgopoulos, G., and W.J. Welch. Role of the major heat shock proteins as molecular chaperones. Annu Rev Cell Biol 9: 601-634, 1993.

15. Gutierrez, J.A., and V. Guerriero Jr. Quantification of HSP70 in tissues using a competitive enzyme-linked immunosorbent assay. J Immunological Methods 143: 81-88, 1991.

16. Hutter, M.M., R.E. Sievers, V. Barbosa, and C.L. Wolfe. Heat-shock protein induction in rat hearts. A direct correlation between the amount of heat-shock protein induced and the degree of myocardial protection. Circulation 89: 355-60, 1994.

17. Karmazyn, M., K. Mailer, and R.W. Currie. Acquisition and decay of heat-shock-enhanced postischemic ventricular recovery. Am I Physiol 259: H424-H431, 1990.

18. Knowlton, A.A., P. Brecher, and C.S.Apstein. Rapid expression of heat shock protein in the rabbit after brief cardiac ischemia. J Cli Inzest 87: 139-147, 1991.

19. Kontos, M.C., J.B. Shipley, and R.C. Kukreja. Heat stress improves functional recovery and induces heat shock protein synthesis without preserving sarcoplasmic reticulum function in the ischemic rat heart. (abstract). I Mol Cell Cardiol 27: A17, 1995.

20. Marber, M.S., R. Mestril, S-H. Chi, M.R. Sayen, D.M. Yellon, and W.H. Dillmann. Overexpression of the rat inducible 70-kD heat stress protein in a transgenic mouse increases the resistance of the heart to ischemic injury. / Clin Invest 95: 1446-1456, 1995.

21. Marber, M.S, J.M. Walker, D.S. Latchman, and D.M. Yellon. Cardiac 72- and 60-kDa stress protein induction by repetitive ischemia and heat stress. J Mol Cell Cardiol 25 (suppl 1): S.55, 1993.

22. Marber, M.S., D.S. Latchman, J.M. Walker, and D.M. Yellon. Cardiac stress protein elevation 24 hours after brief ischemia or heat stress is associated with resistance to myocardial infarction. Circulation 88: 1264-72, 1993. 
23. Marber, M.S., J.M. Walker, D.S. Latchman, and D.M. Yellon. Attenuation by heat stress of a submaximal calcium paradox in the rabbit heart. f Mol Cell Cardiol 25: 1119-1126, 1993.

24. Marber, M.S., J.M. Walker, D.S. Latchman, and D.M. Yellon. Myocardial protection after whole body heat stress in the rabbit is dependent on metabolic substrate and is related to the amount of the inducible 70-kD heat stress protein. / Clin Invest 93: 1087-1094, 1994.

25. McCully, J.D., T. Myrmel, M.M. Lotz, I.B. Krukenkamp, and S. Levitsky. The rapid expression of myocardial HSP70 mRNA and the heat shock $70 \mathrm{kDa}$ protein can be achieved after only a brief period of retrograde hyperthermic perfusion. J Mol Cell Cardiol 27: 873-882, 1995.

26. Milarski, K.L., and R.I. Morimoto. Mutational analysis of the human HSP70 protein: distinct domains for nucleolar localization and adenosine triphosphate binding. / Cell Biol 109: 19471962, 1989.

27. Nelissen-Vrancken, H.J., J.J.M. Debets, L.H.E.H. Snoeckx, and J.F.M. Smits. Time-related normalization of maximal coronary flow in isolated perfused hearts of rats with myocardial infarction. Circ 93: 349-355, 1996.

28. Parsell, D.A., J. Taulien, and S. Lindquist. The role of heat shock proteins in thermotolerance. Philos Trans R Soc London Ser B 339: 279-286, 1993.

29. Plumier, J.C.L., B.M. Ross, R.W. Currie, C.E. Angelidis, H. Kazlaris, G. Kollias, and G.N. Pagoulatos. Transgenic mice expressing the human heat shock protein 70 have improved postischemic myocardial recovery. I Clin Invest 95: 1854-1860, 1995.

30. Riabowol, K.T., L.A. Mizzen, and W.J. Welch. Heat shock is lethal to fibroblasts microinjected with antibodies against hsp70. Science 242: 433-436, 1988.

31. Robinson, B.L., T. Morita, D.O. Toft, and J.J. Morris. Accelerated recovery of postischemic stunned myocardium after induced expression of heat shock protein (HSP70). I Thorac Cardiovasc Surg 109: 753-764, 1995.

32. Sanders Williams, R., J.A. Thomas, M. Fina, Z. German, and I.J. Benjamin. Human heat-shock protein 70 (hsp 70) protects murine cells from injury during metabolic stress. / Clin Invest 92: 503$508,1993$.

33. Skelly, S., C. Fu, B. Dalie, B. Redfield, T. Coleman, N. Brot, and H. Weissbach. Antibody to s32 cross-reacts with dnaK: association of dnaK protein with E.Coli RNA polymerase. Proc Natl Acad Sci 85: 5497-5501, 1988.

34. Skidmore, R., J.A. Gutierrez, V. Guerriero Jr, and K.C. Kregel. HSP70 induction during exercise and heat stress in rats: role of intemal temperature. Am I Physiol (Regulatory Integratioe Comp Physiol 37) 268: R92-R97, 1995.

35. Skowyra, D., and C.M.Z. Georgopoulos. The E.coli dnaK gene product, the hsp70 homolog, can reactive heat-inactivated RNA polymerase in an ATP hydrolysis-dependent manner. Cell 62: 939-944, 1990.

36. Snoeckx, L.H.E.H., R.N.M. Cornelussen, R.S, Reneman, and G.J. van der Vusse. Windows for HSP70. Ann NY Acad Sci in press.

37. Snoeckx, L.H.E.H., F. Contard, J. L. Samuel, F. Marotte, and L. Rappaport. Expression and cellular distribution of heat-shock and nuclear oncogene proteins in rat hearts. Am J Physiol : H1443-H1451, 1991.

38. Steare, S.E, and D.M. Yellon. The protective effect of heat stress against reperfusion arrhythmias in the rat. J Mol Cell Cardiol 25: 1471-1481, 1993.

39. van der Laarse, A., P.R.M. van Dijkman, J.C .Altona, A.C.M. Zoet, and P.V. Oemrawsingh. Coronary flow-rate dependent enzyme release rate from normoxic and anoxic rat hearts in oitro. Cardiovasc Res 18: 438-442, 1984.

40. Wall, S., H. Fliss, and B. Korecky. Role of catalase in myocardial protection against ischemia in heat shocked rats. Mol Cell Biochem 129: 187-194, 1993.

41. Welch, W.J., and J.R. Feramisco. Nuclear and neonuclear localization of the 72.000 dalton heatshoc.k protein in heat-shocked mammalian cells. I Biol Chem 259: 4501-4513, 1984.

42. Welch, WJ., and J.P. Suhan. Cellular and biochemical events in mammalian cells during and after recovery of stress. J Biol Chem 103: 2035-2052, 1986.

43. Yellon, D.M., and M.S. Marber HSP70 in myocardial ischemia. Experientia 50: 1075-1084, 1994 .

44. Yellon, D.M., E. Pasini, A. Cargoni, M.S. Marber, D.S. Latchman, and R. Ferrari. The protective role of heat stress in the ischemic and reperfused rabbit myocardium. / Mol Cell Cardiol 24: 895907, 1992.

45. Yellon, D.M., E. Iliodromitis, D.S. Latchman, D.M. Van Winkle , J.M. Downey, F.M. Williams, and T.J. Williams. Whole body heat stress fails to limit infarct size in the reperfused rabbit heart. Cardiovasc Res 26: 342-6, 1992. 


\section{Summary}

The general aim of the present thesis was to study the protective effects of hyperthermic pretreatment on postischemic mechanical function, if any, in adult and aged hypertrophied rat hearts. These hearts are extremely vulnerable to ischemic damage, generally accompanied by underperfusion of the subendocardial layers of the left ventricular wall. Most of the experiments were performed on isolated, ejecting rat hearts. In addition, cardiomyocytes isolated from heat-shocked rats were used to study in more detail the intracellular calcium homeostasis after hyperthermic pretreatment.

The present state of art regarding heat shock proteins and heat shockmediated cardioprotection is described in Chapter 1 . Heat shock proteins are upregulated or induced by a broad range of environmental stressors, but were originally discovered in heat-shocked cells. This is why they were called heat shock proteins (HSPs). Most HSPs are constitutively expressed and are believed to play an essential role in protein translocation, folding and degradation. The highly inducible HSP of 72 kilodalton (HSP72) expressed at very low levels in the normal cell has been postulated to be solely reponsible for the induced cardioprotection against ischemia and reperfusion damage by hyperthermic pretreatment through renaturation of malfolded or denatured proteins.

In Chapter 2 of this thesis it was shown that the ischemia tolerance of the compensated hypertrophied and non-hypertrophied heart can be improved by whole body heat shock applied 24 hours earlier. Beside significantly enhanced postischemic hemodynamic recovery, hyperthermic pretreatment led to a reduction in postischemic electrical disturbances. In both the hypertrophied and non-hypertrophied heart these cardioprotective effects were associated with increased postischemic coronary flow. In the heat-shocked hypertrophied heart postischemic coronary flow distribution among the layers of the left ventricular wall was more homogeneous, i.e., more equally distributed between subendocardial and subepicardial layers. In the hypertrophied heart the cardioprotective effects of hyperthermic pretreatment against ischemia and reperfusion damage could not be attributed to an increased endogenous catalase activity, because the activity of this hydroxyl scavenging enzyme was not increased in this type of heart. The improved hemodynamic recovery in both the hypertrophied and non-hypertrophied heart was not associated with a reduction in the loss of cytosolic enzymes as lactate dehydrogenase or creatine kinase. This does not imply that there is no protection at the level of the cellular membrane since the washout in the non-heated hearts is hampered (no-reflow phenomenon).

The investigated hearts described in Chapter 2 were all perfused at a coronary perfusion pressure of $8.0 \mathrm{kPa}$. Since the ischemia tolerance of the hypertrophied heart can also be increased when the postischemic coronary perfusion pressure is enhanced to $13.3 \mathrm{kPa}$, it was investigated whether hyperthermic pretreatment was still able to induce cardioprotection in the hypertrophied and non-hypertrophied heart at this enhanced level of coronary perfusion pressure (Chapter 3 ). The results of this study indicate that in the hypertrophied heart the combination of elevated 
coronary perfusion pressure and hyperthermic pretreatment had no additional beneficial effect on postischemic functional recovery, although the loss of cytosolic enzymes was significantly reduced. In contrast, in the non-hypertrophied heart the combination of elevated perfusion pressure and hyperthermic pretreatment resulted in a significant postischemic improvement of some hemodynamic variables. Under these circumstances, however, cardioprotection was less pronounced compared to the level of functional recovery at lower coronary perfusion pressure. In non-hypertrophied hearts perfused at high afterload coronary flow values were significantly enhanced and creatine kinase loss into the coronary effluent was significantly reduced during the initial phase of reperfusion, indicating improved postischemic cellular membrane stability. These experiments indicate that heat shock-induced cardioprotection against an ischemic insult depends on the postischemic coronary perfusion pressure level and thus specifies the perfusion conditions under which cardioprotection can be obtained.

The effects of heat shock on the ischemia tolerance in aged (16 months old) hypertrophied and non-hypertrophied hearts are described in Chapter 4. Hyperthermic pretreatment protected the aged compensated hypertrophied as well as the aged non-hypertrophied heart as evidenced by the higher postischemic hemodynamic recovery and the reduced duration of postischemic ventricular arrhythmias. The cardioprotection of the non-hypertrophied heart, however, was only observed when the duration of the ischemic period lasted so long that the postischemic values of the hemodynamic variables in the non-heated heart were about $20 \%$ of the preischemic values. Again, the postischemic cardioprotection after hyperthermic pretreatment was associated with significantly higher postischemic coronary flow values than in the respective non-heated control hearts, strengthening the hypothesis that improvement of coronary flow may be instrumental in the heat shock-mediated cardioprotection. These findings also indicate that cardioprotection can only be obtained when the ischemia duration is severe enough

In Chapter 5 it is described that the adult non-hypertrophied heart can not be protected against an ischemic insult when the time-interval following heat shock is less than six hours, a time at which the intramyocardial concentration of the major inducible stress protein, i.e. heat shock protein $72 \mathrm{kDa}$ (HSP72), is similar to that observed 24 hours following heat shock. In hearts subjected to ischemia 30 minutes after hyperthermic pretreatment, the postischemic hemodynamic recovery was significantly depressed compared to the non-heated control heart, although the preischemic cardiac performance was completely comparable. These results show that apart from the biphasic nature of heat shock-induced cardioprotection, the absolute amount of the HSP72 protein is not responsible for the heat shock-induced cardioprotection. As such the applicability of hyperthermic pretreatment to improve the ischemia tolerance has to be reserved for periods longer than 6 hours following hyperthermic pretreatment. This observation might be explained by the intracellular localization of HSP72, because the proteins are resided in the nucleus fur the tirst 6 to 8 hours after the hyperthermic pretreatment and then diffuses into the cytosol.

As discussed before, hyperthermic pretreatment may negatively affect postischemic cardiac performance under certain conditions. In Chapter 6 it was shown that preischemic left ventricular function of the isolated, ejecting heart (24 hours after hyperthermic pretreatment) was depressed when the left ventricle had to perform either at low extracellular calcium concentrations of $0.625 \mathrm{mM}$ or at a relatively high coronary perfusion pressure of $16.0 \mathrm{kPa}$. Improvement of 
postischemic functional recovery in hyperthermically pretreated hearts could only be appreciated at relatively low coronary perfusion pressures, i.e. 8.0 to $13.3 \mathrm{kPa}$ in combination with normal extracellular calcium concentrations, i.e. 1-2 mM. At lower extracellular calcium concentrations and/or higher afterload levels the improvement of postischemic function was completely abolished. These results led to the hypothesis that the cellular mechanism of heat shock-mediated cardioprotection is secondary to an altered intracellular calcium homeostasis.

This hypothesis was investigated in isolated cardiomyocytes and the results are described in Chapter 7. Calcium homeostasis was investigated in cardiomyocytes isolated from rat hearts 24 hours after heat pretreatment. The results indicate that heat shock has no major effects on intracellular calcium homeostasis in isolated cardiomyocytes of heat-shocked rats. The resting intracellular calcium concentration and the sensitivity of the contractile apparatus towards changes in extracellular calcium were not different between heated and non-heated cardiomyocytes. Furthermore, the exposure of electrically stimulated or quiescent cells to conditions leading to calcium overload revealed no differences in hypercontracture development between heated and non-heated cardiomyocytes. However, in quiescent cells at $1 \mathrm{mM}$ extracellular calcium concentration, 2 minutes after a challenge with $10 \mathrm{mM}$ extracellular calcium concentration heat-shocked cells retained their absolute cell length while non-heated cells further hypercontracted. The overall conclusion of this investigation might be that subtle changes in "diastolic" rather than "systolic" behavior exist in heat-shocked cardiomyocytes.

In conclusion, it can be stated that hyperthermic pretreatment protects not only the normal heart, but also the more compromised myocardium, like the compensated hypertrophied or aged hypertrophied heart. It should be kept in mind, however, that the cardioprotection is determined by such conditions as the severity of the ischemic period, the length of the time-interval between heat shock and start of ischemia, the availablity of extracellular calcium and the height of the coronary perfusion pressure level. The mechanism behind the heat shock-induced cardioprotection may be attributed to the enhanced postischemic coronary flow and its impoved distribution across the left ventricular wall, although it can not be excluded that changes in intracellular calcium concentrations do contribute to the improvement of postischemic functional recovery. 


\section{Samenvatting}

Een gebrekkige toevoer van bloed (ischemie) naar de hartspier leidt snel tot een afname van de contractiekracht van dit orgaan. Een totale belemmering van de bloedtoevoer kan zelfs aanleiding geven tot onherstelbare beschadiging van de hartspier. Het zo spoedig mogelijk herstellen van de normale bloedstroom van dit weefsel is dan ook van levensbelang. Korte perioden van totale belemmering van bloedtoevoer naar het hart zoals zich voordoet tijdens open-hart chirurgie, kunnen leiden tot definitieve beschadiging van de hartspier indien er geen voorzorgsmaatregelen worden getroffen. Via wetenschappelijk onderzoek heeft men de afgelopen decennia reeds een aantal methoden ontwikkeld om hartspierweefselbeschadiging te voorkomen. Deze methoden berusten op het exogeen toedienen van farmacologisch aktieve stoffen die weefselsterfte voorkomen. De laatste jaren zijn nieuwe methoden ontwikkeld die berusten op het aktiveren van beschermingsmechanismen die in het hart aanwezig zijn. Het doel van deze thesis was te onderzoeken of eén van deze endogene methoden van nut kon zijn bij de bescherming van het hart tegen een kunstmatig opgelegde ischemische periode. Meer in het bijzonder werd onderzocht of het pathologisch vergrootte (hypertrofe) hart kan worden beschermd tegen een ischemische prikkel, omdat het hypertrofe hart bijzonder gevoelig is voor ischemische beschadiging, en daardoor klinisch een probleem vormt van blijvende zorg. De in deze thesis beschreven methode van endogene bescherming berust op het induceren van eiwitten in het hartspierweefsel, die onder normale omstandigheden nauwelijks of niet aanwezig zijn. Bijna elke cel in het menselijk lichaam is in staat tot de synthese van deze eiwitten, die een centrale rol spelen bij de bescherming van de cel tegen een opgelegde stress. Deze eiwitten hebben dan ook de toepasselijke naam 'stress eiwitten', maar worden ook nog vaak aangeduid als 'heat-stress eiwitten (HSP's)' omdat zij voor de eerste maal werden gevonden na het toedienen van een 'heat stress'. Het onderzoek zoals beschreven in deze thesis werd grotendeels uitgevoerd in het hypertrofe rattehart, dat werd onderzocht in een daartoe speciaal ontworpen toestel. Met behulp van dit toestel kan de functie van het hart buiten het lichaam onder zeer gecontroleerde omstandigheden worden blootgesteld aan een periode van ischemie. Ook werd gebruik gemaakt van hartspiercellen, die werden geïsoleerd uit hartspierweefsel, dat voorafgaand werd onderworpen aan een kortdurende verhoging van de omgevingstemperatuur (hypertherme voorbehandeling).

Deze thesis wordt ingeleid met een algemene beschrijving van de huidige kennis omtrent de heat-stress eiwitten en hun functie. Men maakt onderscheid tussen eiwitten die altijd in weefsels aanwezig zijn (constitutieve eiwitten) en deze die worden aangemaakt tengevolge van een extern opgelegde stress (induceerbare eiwitten). De tot op heden meest uitgebreid onderzochte groep HSP's behoort tot een familie eiwitten met een vergelijkbaar moleculair gewicht van ongeveer 70 kilodalton. Deze HSP70-familie omvat o.a. een constitutief aanwezig HSP73 eiwit en een induceerbaar HSP72 eiwit. Met name dit laatste eiwit speelt een belangrijke rol bij de bescherming van het hart tegen ischemische beschadiging (Hoofdstuk 1). 
Hoofdstuk 2 beschrijft de experimenten die werden uitgevoerd op hypertrofe rattenharten tijdens de fase waarin het hypertrofie-proces nog geen nadelige effecten heeft op de normale pompfunctie van het hart, algemeen omschreven als gecompenseerde hypertrofie. Ten einde de synthese van HSP's te stimuleren in deze harten werden de proefdieren 24 uur voor het experiment gedurende 15 minuten blootgesteld aan een omgevingstemperatuur, die de lichaamstemperatuur deed toenemen tot $42^{\circ} \mathrm{C}$. Deze handeling wordt doorgaans aangeduid als 'heat stress'. Ten behoeve van het experiment werden de harten geïsoleerd uit het lichaam en kunstmatig doorstroomt met een op bloed-gelijkende buffer-oplossing in een geïsoleerd-hart opstelling. In deze opstelling kan de pompfuctie van de linker hartkamer nauwkeurig worden geëvalueerd. Na een korte periode van normale doorstroming werd de vloeistoftoevoer naar de kransslagaders volledig afgesloten en aldus een toestand van totale ischemie nagebootst. Tijdens deze periode viel de hartactie volledig stil. Daarna werd de vloeistoftoevoer hersteld en werd het herstel van de pompfunctie van de linker hartkamer vergeleken met deze vórr het ischemisch insult. Aldus kon worden vastgesteld dat het functionele herstel van het voorbehandelde hypertrofe hart significant was toegenomen in vergelijking met dat in het niet-voorbehandelde hypertrofe hart. Dit toegenomen herstel werd begeleid door een aantal opvallend positieve fenomenen. Zo werd vastgesteld dat de doorstroming van de binnenste lagen (subendocard) van de linker hartkamer van het hypertrofe hart nagenoeg normaal was. Dit in tegenstelling tot het niet-behandelde hart, waarin een sterke afname werd waargenoemen van de subendocardiale doorstroming na het ischemisch insult. Daarnaast werd eveneens een sterke reducering vastgesteld van de duur van postischemische ritmestoornissen. Echter, twee fenomenen die door andere onderzoekers werden beschreven in niet-hypertrofe harten konden door ons niet worden bevestigd. Ten eerste werd er in het hypertrofe hart geen afname gevonden in het verlies van eiwitten uit het hartspierweefsel. De mate van verlies van deze eiwitten is recht evenredig met de beschadiging van de celwand van hartspiercellen. Een afname van verlies zou dan ook betekenen dat de celwand beter beschermd zou zijn. Dat ik geen afname heb kunnen vaststellen wil echter niet betekenen dat er geen bescherming optrad ter hoogte van de celwand, omdat een afgenomen doorstroming van bepaalde hartdelen, zoals zij zich voordeed in de niet-voorbehandelde harten, het uitwassen van eiwitten belemmerd. Ten tweede heb ik de toegenomen activiteit van het enzym catalase in voorbehandelde ratten niet kunnen bevestigen in het hypertrofe hart. Dit enzym voorkomt beschadiging van de celwand door het wegvangen van hydroxylradicalen die worden gevormd tijdens de eerste minuten na de ischemische periode, tijdens dewelke het normale zuurstofaanbod wordt hersteld.

In eerder onderzoek aan gecompenseerde hypertrofe harten heeft men kunnen vaststellen dat de hoogte van de bloeddruk, tegen welke het hart moet pompen, de mate van herstel na een ischemische fase beïnvloedt. Zo is gebleken dat hypertrofe harten beter herstellen na een ischemische periode indien deze druk relatief hoog is. Een attractieve hypothese was dan ook dat de combinatie van hoge druk en hypertherme voorbehandeling een gunstig additief effect heeft op de mate van het postischemich functioneel herstel van het hypertrofe hart. Deze hypothese werd onderzocht in experimenten beschreven in Hoofdstuk 3. De resultaten tonen echter dat deze hypothese moet worden verworpen. Alhowel het functioneel herstel in de combinatie-behandelde harten vrij hoog was, konden geen statistische verschillen worden waargenomen met hypertofe harten die geen hypertherme voorbehandeling hadden ondergaan en enkel werden doorstroomd met hoge druk. 
Het verlies van eiwitten door de celwand heen was wel beperkt in de hypertherm voorbehandelde harten. Deze bevindigen lieten geen éénduidige conclusie over het al-dan-niet positief effect van combinatie-behandeling toe.

De resultaten zoals beschreven in de hoofdstukken 2 en 3 laten zien dat er protectie optreedt van de cardiale functie na een ischemische periode in het gecompenseerde hypertrofe hart indien er een hypertherme voorbehandeling was gegeven. Een mogelijk nog interessanter model om de potentie van deze techniek te evalueren is het oude hypertrofe hart, waarin de pompfunctie van de linker hartkamer dreigt te falen. Daartoe werden experimenten uitgevoerd in hypertofe harten van 16 maanden oude ratten. Het experimentele protocol was nagenoeg identiek aan dat beschreven in de hoofdstukken 2 en 3 , en de resultaten zijn te vinden in Hoofdstuk 4 van deze thesis. Ook in deze harten kon worden aangetoond dat hypertherme voorbehandeling een gunstig effect heeft op de mate van postischemisch functieherstel. Tevens werd, zoals in de volwassen hypertrofe harten, een reductie van de duur van postischemische ritmestoornissen vastgesteld. Ook in deze voorbehandelde harten werd een significante toename van de doorstroming van de kransslagaders gevonden. Deze bevinding versterkt de conclusie dat de toename van doorstroming van de kransslagaders, die wordt geïnduceerd door hypertherme voorbehandeling, een cruciale rol speelt in het fenomeen van toegenomen ischemietolerantie. Het preciese mechanisme dat tot deze varandering in de vaten van het kransslagadersysteem leidt is tot op heden nog niet bekend, en moet in toekomstig onderzoek worden onderzocht.

De experimenten beschreven in de hoofdstukken 2 tot en met 4 richtten zich vooral op de effecten van hypertherme voorbehandeling in hypertrofe harten. De experimenten beschreven in de hoofdstukken 5 tot en met 7 hebben tot doel gehad een beter inzicht te verwerven in de omstandigheden waarbij het beschermende effect van hypertherme voorbehandeling kan worden waargenomen en in het werkingsmechanisme dat ten grondslag ligt aan dit beschermend effect.

Het is reeds geruime tijd bekend dat de induceerbare stress eiwitten behoren tot de groep van 'early gene products', wat betekent dat hun synthese zeer snel na het toedienen van de stress prikkel op gang komt. Zo is het bekend dat de synthese van het induceerbare HSP72 eiwit reeds start binnen én uur volgend op de stress prikkel en maximale HSP72 eiwit hoeveelheden worden bereikt binnen 6 uur volgend op de prikkel. Indien een directe oorzakelijke relatie bestaat tussen de mate van bescherming tegen een ischemische beschadiging en de hoeveelheid HSP72 eiwit aanwezig in de hartspier, dan kan worden gepostuleerd dat de mate van bescherming tijdens de eerste 6 uren volgend op de stress prikkel progressief toeneemt. Dit postulaat werd onderzocht in de experimenten beschreven in Hoofdstuk 5. Aan proefdieren werd een hypertherme behandeling toegediend en 0 , $0.5,1,3,6$, en 24 uur later werd de gevoeligheid voor ischemische beschadiging onderzocht zoals eerder beschreven. Op alle vernoemde tijdstippen tot en met 6 uur na het toedienen van de stress prikkel werd echter geen toegenomen postischemisch functioneel herstel waargenomen. Bovendien werden evenmin andere positieve fenomenen, zoals afgenomen duur van ritmestoornissen en verminderde uitstort van eiwitten door de celwand heen gevonden. Echter, 24 uur na het toedienen van de hypertherme stress prikkel werd een statistisch significant toegenomen postischemisch functioneel herstel waargenomen, evenals de reeds eerder vernoemde gunstige bevindingen. De belangrijke conclusie van deze studie was dat de mate van postischemisch herstel binnen de eerste 6 uren volgend op de stress prikkel niet oorzakelijk kan worden gekoppeld aan de hoeveelheid HSP72 eiwit in het hartspierweefsel. 
Eveneens werd onderzoek verricht naar de pompfunctie van het hypertherm voorbehandelde hart tijdens de fase voorafgaand aan de ischemische fase. Dit onderzoek wordt beschreven in Hoofdstuk 6. Proefdieren werden op de klassieke wijze onderworpen aan een hypertherme voorbehandeling. Vierentwintig uur later werd het hart geïsoleerd en kunstmatig doorstroomd in het geïsoleerde hartpreparaat. Tijdens de fase voorafgaand aan de ischemische periode werd zowel de druk waartegen de linker hartkamer moest ejecteren, alsook de concentratie van calcium-ionen in de doorstromingsvloeistof kunstmatig gevariëerd. Beide ingrepen waren bedoeld om de pompfunctie van het hart te testen onder extreme omstandigheden. Bij hoge druk werd de maximale belastbaarheid van het hart getest, terwijl variaties in de calciumconcentratie buiten de cel de beschikbaarheid van calcium in de hartspiercel beinvloedde, en aldus de mate van contractiekracht. Deze experimenten toonden aan dat de contractiekracht van het hypertherm voorbehandelde hart normaal was bij normale drukbelasting en normale calciumconcentraties, maar negatief van de norm afweek wanneer de drukbelasting hoog of de calciumconcentratie erg laag was. Deze waarnemingen werden bevestigd tijdens de herstelfase na de ischemische beschadiging. Indien tijdens deze fase dezelfde variaties werden aangebracht bleek het gunstige effect van hypertherme voorbehandeling op de pompfunctie van de linker hartkamer volledig te verdwijnen. Deze resultaten suggereerden dat hypertherme voorbehandeling leidt tot veranderingen in de calcium-huishouding in de hartspiercel. Deze veranderingen kunnen bestaan uit een afgenomen gevoeligheid van de contractiele eiwitten voor calcium, danwel uit veranderingen in de hoeveelheid calcium die in de cel worden vrijgesteld tengevolge van veranderingen in de calciumconcentratie buiten de cel.

l'eneinde deze hypotheses te toetsen werden experimenten uitgevoerd in hartspiercellen, geïsoleerd uit harten afkomstig uit proefdieren 24 uur na een hypertherme voorbehandeling. De resultaten van deze experimenten worden beschreven in Hoofdstuk 7. Hartspiercellen werden verrijkt met de fluorescerende kleurstof FURA-2, die de eigenschap bezit zich te hechten aan vrije calcium-ionen binnen de cel, wat inhoudt dat de mate van FURA-2 fluorescentie een maat is voor calcium concentratie. Bij een normale calciumconcentratie in de badvloeistof waarin de geisoleerde cellen zich bevonden, werden normale cellulaire contractiepatronen en schommelingen van de calciumconcentratie waargenomen. Echter, wanneer de cellen eerst werden blootgesteld aan een hoge calcium badconcentratie, en daarna naar normale calcium badconcentraties bleek dat hypertherm voorbehandelde cellen beter in staat waren hun normale lengte te behouden dan niet-voorbehandelde cellen. Deze waarnemingen hebben geleid tot de conclusie dat hypertherme voorbehandeling interfereert met de calciumhuishouding in de hartspiercel, en leidt tot een beter behoud van normale cellengte na extreme belastingen. Deze bevindingen kunnen van groot belang zijn voor het intacte hart tijdens het herstel na een periode van ischemie, omdat het bekend is dat hartspiercellen tijdens deze fase abnormale hoeveelheden calcium ionen kunnen accumuleren, die op hun beurt een negatief effect hebben op het contractiele gedrag van de hartspier.

Deze thesis heeft geleid tot de algemene conclusie dat hypertherme voorbehandeling van het gecompenseerde en oude hypertrofe hart een gunstig effect heeft op de gevoeligheid voor ischemische beschadiging. Het stimuleren van de synthese van induceerbare stress eiwitten in het hart biedt een nieuwe mogelijkheid tot bescherming tegen ischemische prikkeling, gebruik makende van beschermingsmechanismen die endogeen aanwezig zijn. Verder onderzoek is 
noodzakelijk om het werkingmechanisme van stress eiwitten volledig te begrijpen. Met name het preciese mechanisme leidend tot de expressie van induceerbare stress eiwitten is tot op heden nauwelijks gekend. Kennis van deze route zou aanleiding kunnen geven tot het onderzoeken van andere, mogelijk farmacologische, wegen die leiden tot de genetische expressie van protectieve stress eiwitten. 


\section{Publications and Abstracts}

\section{Full Papers}

1. Cornelussen R., Spiering W., Webers J.H.G., de Bruin L.G., Reneman R.S., van der Vusse G.J., Snoeckx L.H.E.H. Heat-shock improves the ischemia tolerance of the hypertrophied heart. Am. J. Physiol. 267 (Heart Circ Physiol 36): H1941H1947, 1994.

2. Cornelussen R., Reneman R.S., van der Vusse G.J., Snoeckx L.H.E.H. Inability of the heat-shocked heart to adjust its preischemic and postischemic performance to variable loading conditions. J. Mol. Cell. Cardiol 28: 291-299, 1996

3. Snoeckx L.H.E.H., Cornelussen R, Reneman R.S., van der Vusse G.J. Windows for HSP70. Ann. NY. Acad. Sci. in press

4. Cornelussen R., Ver Donck L, Verellen G, Borgers M, Reneman R.S., van der Vusse G.J., Snoeckx L.H.E.H. Calcium homeostasis in cardiomyocytes isolated from heat-shocked rats. Am. J. Physiol. in press

5. Cornelussen R., Reneman R.S., van der Vusse G.J., Snoeckx L.H.E.H. Heat shock-induced cardioprotection of the aged hypertrophied rat heart. Under revision

6. Cornelussen R., Vork M.M., de Bruin L.G.A., Reneman R.S., van der Vusse G.J., Snoeckx L.H.E.H. Biphasic effect of hyperthermic pretreatment on the ischemia tolerance of isolated rat hearts. Submitted

\section{Publication in book}

1. Cornelussen R., de Bruin L.G., van der Vusse G.J., Snoeckx L.H.E.H. Is the postischemic heat-shock mediated protection of the hypertrophied rat heart perfusion pressure dependent? In: Proceedings of the 1994 ISHR European Section Meeting. Eds: Haunsõ S, Kjeldsen K. Monduzzi Editore 1994, pp. 559-563

\section{Abstracts}

1. Snoeckx L.H.E.H., Cornelussen R.N., van der Vusse G.J., and Reneman R.S. The expression of heat shock protein 70kDa (HSP70) in the hypertrophied and non-hypertrophied heart of heat-shocked rats. FASEB J 6: A1259, 1992

2. Cornelussen R.N., Snoeckx L.H.E.H., de Bruin L.G., van der Vusse G.J., and Reneman R.S. Improvement of post-ischemic functional recovery of hypertrophied rat hearts by the induction of heat-shock proteins. Eur. J. Physiol. (Pflügers Arch.) 421: R36, 1992.

3. Cornelussen R.N., Snoeckx L.H.E.H., de Bruin L.G., van der Vusse G.J., and Reneman R.S., and Rappaport L. Localisation of the inducible HSP70 protein in the hypertrophied and non-hypertrophied heart following heat-shock. The Histochem. J. 24: 491, 1992. 
4. Cornelussen R.N., Snoeckx L.H.E.H., de Bruin L.G., van der Vusse G.J., and Reneman R.S. Hyperthermic preconditioning improves ischemia tolerance in the hypertrophied and non-hypertrophied rat heart. J. Mol. Cell. Cardiol. 25: S.56, 1993

5. Snoeckx L.H.E.H., Cornelussen R.N., van der Vusse G.J., and Reneman R.S. Post-ischemic electrical stability in the heat-shocked hypertrophied and nonhypertrophied rat heart. J. Mol. Cell. Cardiol. 25: S.56, 1993

6. Cornelussen R.N., Snoeckx L.H.E.H., van der Vusse G.J., Reneman R.S. Hyperthermia reduced ischemia vulnerability is associated with improved coronary perfusion and electrical stability in the hypertrophied and nonhypertrophied rat heart. IUPS, Glasgow, 27: 16a, 1993

7. Spiering W., Webers J., Cornelussen R., Snoeckx L.H.E.H., van der Vusse G.J., Reneman R.S. Is the post-ischemic heat-shock mediated protection of the hypertrophied rat heart perfusion pressure dependent? J. Mol. Cell. Cardiol. 26: 72,1994

8. Cornelussen R., Snoeckx L.H.E.H., van der Vusse G.J., Reneman R.S. Heatshock improves the post-ischemic left ventricular pump performance in the hypertrophied heart. J. Mol. Cell. Cardiol. 26: 72, 1994

9. Cornelussen R, Ver Donck L, Verellen G, Borgers M, van der Vusse G, Reneman $\mathrm{R}$, Snoeckx L. Ca ${ }^{2+}$-homeostasis in isolated rat cardiomyocytes is not affected 24 hours after in-vivo heat stress. Eur. J. Physiol. (Pflügers Arch.) 430: R146, 1995

10. Cornelussen R, Vork M, van der Vusse G.J., Reneman R.S., Snoeckx L.H.E.H. Time- related effects of heat stress on cardiac protection against ischemia and reperfusion in the isolated rat heart. Eur. J. Physiol. (Pflügers Arch.) 430: R20, 1995

11. Cornelussen R., van der Vusse G.J., Reneman R.S., Snoeckx L.H.E.H. Heat stress protects the aged hypertrophied rat heart against ischemia and reperfusion injury. FASEB J 10: A263, 1996

12. Cornelussen R., van der Vusse G.J., Reneman R.S., Snoeckx L.H.E.H. Biphasic effect of heat stress pretreatment on the ischemic tolerance of isolated hearts. Eur. J. Physiol. (Pflügers Arch.) in press 


\section{Curriculum vitae}

De schrijver van dit proefschrift werd geboren op 4 december 1967 te Maastricht. Na het behalen van het VWO-B diploma aan het Stedelijk Lyceum te Maastricht in juni 1986, werd in hetzelfde jaar begonnen met de opleiding tot biochemisch analist aan de Zuidlimburgse Laboratoriumschool Sittard. De stage en afstudeerperiode werd doorgebracht bij de Vakgroep Celbiologie en Genetica aan de Rijksuniversiteit Limburg te Maastricht. Het diploma "Hoger Laboratorium Onderwijs" werd in 1990 behaald, waarna een jaar als biochemische analist werd doorgebracht bij de Vakgroep Fysiologie van het Cardiovasculair Research Instituut Maastricht aan de Rijksuniversiteit Limburg te Maastricht. Van december 1991 tot maart 1996 was hij werkzaam als Assistent In Opleiding bij dezelfde Vakgroep, alwaar hij de werkzaamheden zoals beschreven in dit proefschrift uitvoerde. 


\section{Dankwoord}

Een proefschrift schrijf je nooit alleen en daarom wil ik de mensen bedanken die op welke manier dan ook een waardevolle bijdrage hebben geleverd die tot dit proefschrift hebben geleid. Toch zijn er een paar mensen die ik in het bijzonder wil bedanken. Mijn begeleider en co-promotor Luc Snoeckx, die mij de kans gaf om te promoveren. Luc, vooral de persoonlijke betrokkenheid (niet alleen op wetenschappelijk gebied) heb ik in jou gewaardeerd. De beide promotoren, Ger van der Vusse en Rob Reneman wil ik bedanken voor de stimulerende discussies en kritische evaluatie van het onderzoek. Voorts wil ik alle drie bedanken voor de hogesnelheidslijn die bestond in het nakijken van de manuscripten.

Naast de medewerkers van de Vakgroep Fysiologie wil ik de stagiaires, Maurice, Migel, Nathalie Roger en Twan bedanken voor het verrichten van de enzymbepalingen. De wetenschapstage studenten Wilco en Jos, bedankt voor jullie ondersteuning bij de hogedruk experimenten. Léon, nog bedankt voor de eiwitbepalingen, Northern blots en vele immunologische kleuringen in een grijs verleden. Michaël wil ik danken voor de hulp bij hoofdstuk 5. Ook gaat een woord van dank uit naar de leden van de beoordelingscommissie, Prof. dr. J.W. Arends, Prof. dr. M. Borgers, Dr. L. Rappaport, Prof. dr. J.F.M. Smits en Prof. dr. A. van der Laarse.

Luc Ver Donck, Greet Verellen en Marcel Borgers wil ik danken voor hun bijdrage aan hoofdstuk 7. Alice, during your stay in Maastricht we had a lot of fruitful discussions, many thanks. Speciale dank voor mijn kamergenoten en de vaste bezoekers van de "In de Zoete Inval" voor de goede discussies.

Aggie, in die afgelopen 4-5 jaar zijn we nog meer naar elkaar toe gegroeid. 

